\section{OAK RIDGE NATIONAL LABORATORY}

MARTIN MARUETIA

\section{ANALYSIS OF HFIR PRESSURIZER PUMP OVERSPEED TRANSIENTS AND REIIEF VALVE PERFORMANCE}

Michael C. Sozer

Engineering Technology Division

Oak Ridge National Laboratory

$$
\begin{gathered}
\text { HE } \\
\text { OS20 } \\
\text { O }
\end{gathered}
$$




\section{DISCLAIMER}

This report was prepared as an account of work sponsored by an agency of the United States Government. Neither the United States Government nor any agency thareof, nor any of their employees, makes any werranty, express or implied, or assumes any legal liability or responsibility for the accuracy, completeness, or usefulness of any information, apparatus, product, or process disclosed, or represents that its use would not infringe privately owned rights. Reference herein to any specific commercial product, process, or service by trade name, tredemark, manufacturer, or otherwise, does not necessarily constitute or imply its endorsement, recommendation, or fevoring by the United States Government or any agency thereof. The views and opinions of authors expressed herein do not necessarily state or reflect those of the United States Government or any agency thereof. 
ORNL/TM-12215

\section{ANALYSIS OF HFIR PRESSURIZER PUMP OVERSPEED TRANSIENTS AND RELIEF VALVE PERFORMANCE}

by

Michael C. Sozer

Engineering Technology Division

Oak Ridge National Laboratory

September 11, 1992

The work performed for

The Research Reactors Division

Oak Ridge National Laboratory

Prepared by the

OAK RIDGE NATIONAL LABORATORY

Oak Ridge, Tennessee 37831

managed by

MARTIN MARIETTA ENERGY SYSTEMS, INC.

for the

U.S. DEPARTMENT OF ENERGY under Contract No. DE-AC05-840R21400 
Page

LIST OF FIGURES $\ldots \ldots \ldots \ldots \ldots \ldots \ldots \ldots \ldots \ldots \ldots \ldots \ldots \ldots, \mathbf{v}$

LIST OF TABLES $\ldots \ldots \ldots \ldots \ldots \ldots \ldots \ldots \ldots \ldots \ldots \ldots \ldots \ldots \ldots \ldots \ldots \ldots \ldots \ldots$

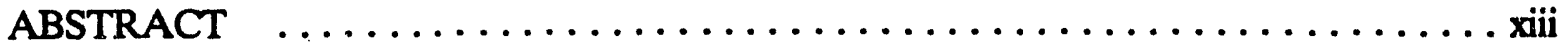

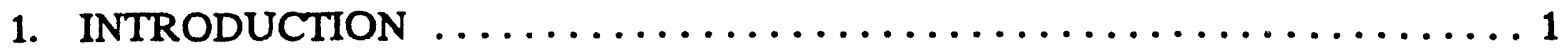

2. PRESSURE RELIEF SUBSYSTEM $\ldots \ldots \ldots \ldots \ldots \ldots \ldots \ldots \ldots \ldots \ldots \ldots \ldots \ldots \ldots \ldots \ldots$

3. RELIEF VALVES AND MODELING CONSIDERATIONS $\ldots \ldots \ldots \ldots \ldots$. 5

3.1 SAFETY VALVES AND RELIEF VALVES $\ldots \ldots \ldots \ldots \ldots \ldots \ldots$

3.2 STABILITY OF A COUPLED RELIEF VALVE-PIPING

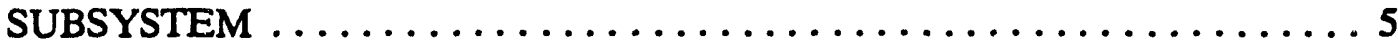

3.2.1 Effects of Upstream Piping $\ldots \ldots \ldots \ldots \ldots \ldots \ldots \ldots \ldots \ldots$

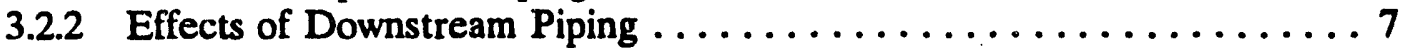

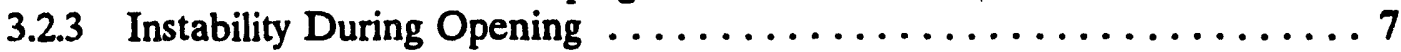

3.2.4 Instability During Closing .................... 9

3.2.5 Effects of Guide Ring Settings, Spring Forces, and Back

Pressure ............................... 9

3.2.6 Relief Valve Opening and Closing Times ............... 11

3.2.7 RELAP5 Simulations of Relief Valve Performances ........... 15

3.2.8 Significant Factors in Modeling Relief Valves . . . . . . . . . . . 16

4. HFIR SYSTEM TRANSIENT ANALYSIS MODEL AND RELIEF

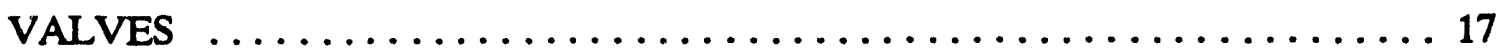

4.1 HFIR SYSTEM TRANSIENT ANALYSIS COMPUTER CODE

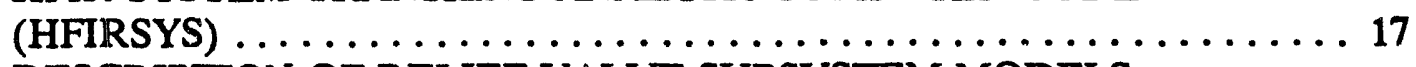

4.2 DESCRIPTION OF RELIEF VALVE SUBSYSTEM MODELS

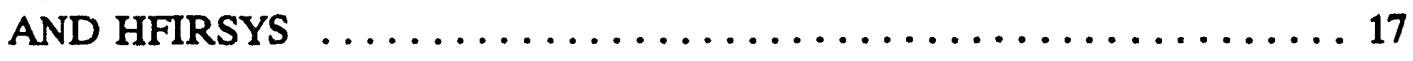

5. HFIRSYS SIMULATIONS OF THE PRESSURIZER PUMP OVERSPEED

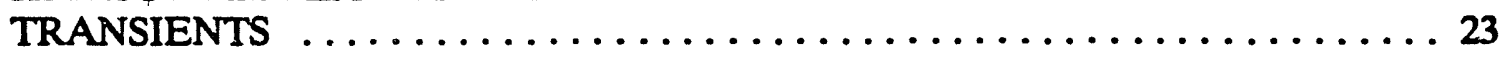

5.1 CONSTRAINTS IMPOSED ON PRESSURIZER PUMP OVERSPEED TRANSIENTS $\ldots \ldots \ldots \ldots \ldots \ldots \ldots \ldots \ldots \ldots \ldots$

5.2 PRESSURIZER PUMP OVERSPEED WITH ALL MITIGATING EQUIPMENT OPERATIONAL (CASE 1A1) ............. 24 
iii

CONTENTS (continued)

Page

5.3 PRESSURIZER PUMP OVERSPEED WITH ALL MITIGATING EQUIPMENT OPERATIONAL (CASE 1B1) $\ldots \ldots \ldots \ldots \ldots \ldots \ldots, 28$

5.4 PRESSURIZER PUMP OVERSPEED WITH FAILURE OF THE HIGH DISCHARGE PRESSURE TRIP (CASE 3A1) ........... 28

5.5 PRESSURIZER PUMP OVERSPEED WITH FAILURE OF THE HIGH DISCHARGE PRESSURE TRIP (CASE 3B1) $\ldots \ldots \ldots \ldots \ldots, 32$

5.6 PRESSURIZER PUMP OVERSPEED WITH FAILURE OF HIGH DISCHARGE AND LOW SUCTION PRESSURE TRIPS

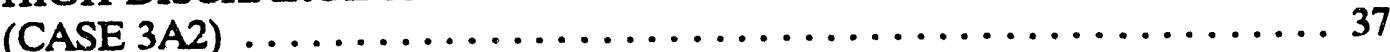

5.7 PRESSURIZER PUMP OVERSPEED WITH FAILURE OF HIGH DISCHARGE AND LOW SUCTION PRESSURE TRIPS (CASE 3B2)

5.7.1 Effects of Partially Open Relief Valve and Valve Characteristics ..............................49

5.7.2 Effects of $\mathrm{K}_{\mathrm{w}}$ (Back Pressure Ratio) $\ldots \ldots \ldots \ldots \ldots \ldots \ldots \ldots . \ldots$

6. INDEPENDENT RELIEF VALVE SUBSYSTEM MODEL $\ldots \ldots \ldots \ldots \ldots 62$

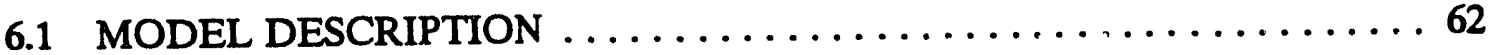

6.1.1 Modifications to MMS modules $\ldots \ldots \ldots \ldots \ldots \ldots \ldots \ldots \ldots$

6.2 ANALYSIS OF RELIEF VALVE PERFORMANCE AND

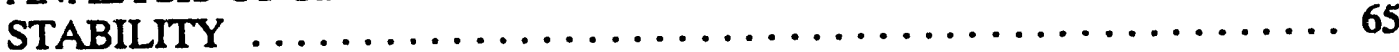

6.2.1 Effects of Pressure and Flow Oscillations on Relief Valve Performance ........................66 66

6.2.2 Effects of Different Cold Leg Pressurization Rates on Relief Valve Opening Time ...................81

6.2.3 Effects of Closed Relief Valve Path on Open Relief Valve Performance ....................... 86

6.2.4 Effects of Different Valve Position Changing Rates and Pressure Set Points on Relief Valve Performances ........... 92

6.2.5 Effects of Outlet Pressure on Relief Valve Performance . . . . . . . . . 104

6.2.5.1 An assumed model of outlet pressure effect on relief valve opening pressure ................. 104

6.2.5.2 Analysis of outlet pressure effect on relief valve performance 105 
iv

CONTENTS (continued)

Page

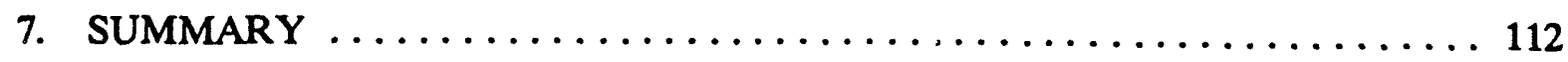

REFERENCES $\ldots \ldots \ldots \ldots \ldots \ldots \ldots \ldots \ldots \ldots \ldots \ldots \ldots \ldots \ldots \ldots \ldots \ldots \ldots$ 


\section{LIST OF FIGURES}

Figure

Page

HFIR Pressure Relief System - Process Flow Diagram .......... 4

2 Relief valve position vs pressure reproduced from Reference $3 \ldots \ldots \ldots .8$

3 Schematic of a typical relief valve in the closed position reproduced from:

RELAP5/MOD2 Code Manual Volume 1: Code Structure, Systems

Models, and Solution Methods NUREG/CR-4312, Aug. 1985) . . . . . 10

4 The schematic drawing of the HFIRSYS model $\ldots \ldots \ldots \ldots \ldots \ldots$

5 The block diagram of the HFIRSYS model $\ldots \ldots \ldots \ldots \ldots$

1a1.1 The pressurizer pump speed for pressurizer pump overspeed transient

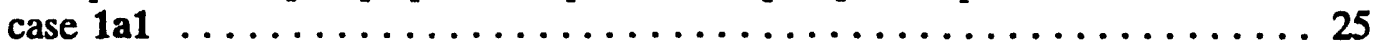

1a1.2 The reactor inlet and outlet pressures for pressurizer pump overspeed

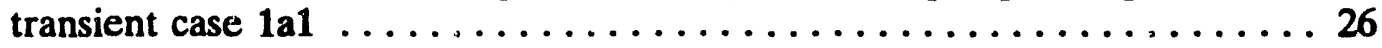

1a1.3 The pressurizer pump and letdown flow rates for pressurizer pump

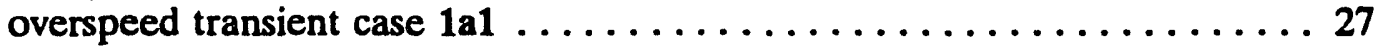

3a1.1 The pressurizer pump speed for pressurizer pump overspeed transient case 3a1

3a1.2 The reactor inlet and outlet pressures for pressurizer pump overspeed transient case $3 \mathbf{a l}$

3a1.3 The relief valve flow rate for pressurizer pump overspeed transient case $3 \mathbf{a 1}$

3a1.4 The pressurizer pump and letdown flow rates for pressurizer pump overspeed transient case $3 \mathrm{a} 1$

3b1.1 The pressurizer pump speed for pressurizer pump overspeed transient case $3 \mathrm{~b} 1$

3b1.2 The reactor inlet and outlet pressures for pressurizer pump overspeed transient case $3 \mathrm{~b} 1$

3b1.3 The relief valve flow rate for pressurizer pump overspeed transient case $3 \mathbf{b 1}$ 
vi

LIST OF FIGURES (continued)

Figure

Page

3b1.4 The pressurizer pump and letdown flow rates for pressurizer pump overspeed transient case $3 b 1 \ldots \ldots \ldots \ldots \ldots \ldots \ldots \ldots \ldots \ldots \ldots$

3a2.1 The pressurizer pump speed for pressurizer pump overspeed transient

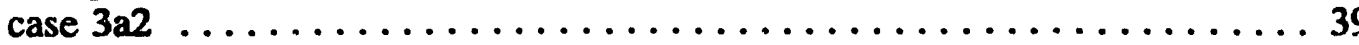

3a2.2 The reactor inlet and outlet pressures for pressurizer pump overspeed

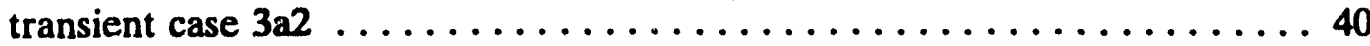

3a2.3 The relief valve flow rate for pressurizer pump overspeed transient

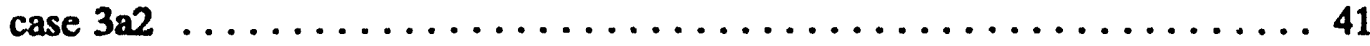

3a2.4 The pressurizer pump and letdown flow rates for pressurizer pump

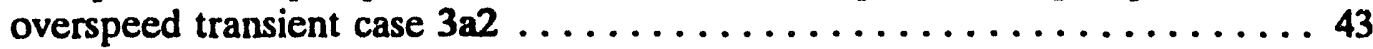

3b2.1 The pressurizer pump speed for pressurizer pump overspeed transient

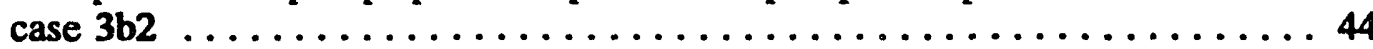

3b2.2 The reactor inlet and outlet pressures for pressurizer pump overspeed

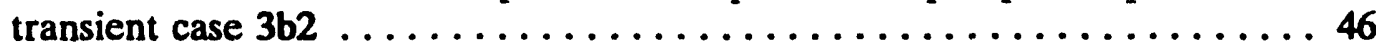

3b2.3 The relief valve flow rate for pressurizer pump overspeed transient case $3 \mathrm{~b} 2$

3b2.4 The pressurizer pump and letdown flow rates for pressurizer pump overspeed transient case $3 \mathrm{~b} 2$

3b2a7.1 The reactor inlet and outlet pressures for pressurizer pump overspeed transient case $3 \mathrm{~b} 2 \mathrm{a} 7$

3b2a7.2 The relief valve flow rate for pressurizer pump overspeed transient case 3b2a7

3b2b7.1 The reactor inlet and outlet pressures for pressurizer pump overspeed transient case $3 \mathrm{~b} 2 \mathrm{~b} 7$

$3 \mathrm{~b} 2 \mathrm{~b} 7.2$ The relief valve flow rate for pressurizer pump overspeed transient case $3 \mathrm{~b} 2 \mathrm{~b} 7$

3b2c7.1 The reactor inlet and outlet pressures for pressurizer pump overspeed transient case $3 \mathrm{~b} 2 \mathrm{cc} 7$ 
vii

\section{LIST OF FIGURES (continued)}

Figure

Page

$3 \mathrm{~b} 2 \mathrm{c} 7.2$ The relief valve flow rate for pressurizer pump overspeed transient

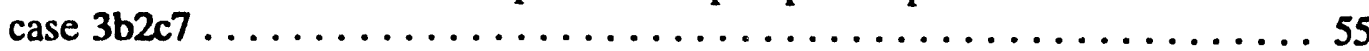

3b2kw.1 The pressurizer pump speed for pressurizer pump overspeed

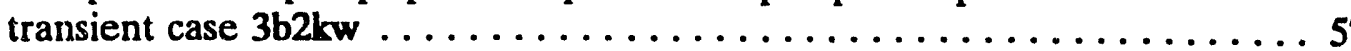

3b2kw.2 The reactor inlet and outlet pressures for pressurizer pump overspeed

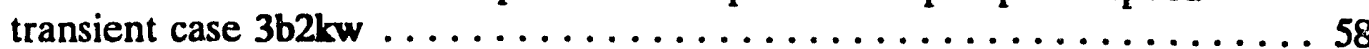

$3 \mathrm{~b} 2 \mathrm{kw} .3$ The relief valve flow rate for pressurizer pump overspeed transient case $3 \mathbf{b} 2 \mathbf{k w}$

$3 \mathrm{~b} 2 \mathrm{kw} .4$ The pressurizer pump and letdown flow rates for pressurizer pump overspeed transient case $3 \mathbf{b} 2 \mathbf{k w}$

1.1 The relief valve position for a position changing rate based on $10 \mathrm{~ms}$ opening or closing time and $\mathbf{7 0 3}$ psia pressure set point one-open-path-model

1.2 The relief valve inlet pressure for a position changing rate based on 10 ms opening or closing time and 703 psia pressure set point one-open-path-model

1.3 The flow rates at the inlet of $11 / 2$ in. pipe and through the relief valve for a position changing rate based on $20 \mathrm{~ms}$ opening or closing time and $7(13$ psia pressure set point - one-open-path-model

1.4 The pressures at the inlet of $11 / 2$ in. pipe and the cold leg for a valve position changing rate based on $20 \mathrm{~ms}$ opening or closing time and 703 psia pressure set point - one-open-path-model

1.5 The cold leg pressure for a position changing rate based on $\mathbf{1 0} \mathrm{ms}$ opening or closing time and $\mathbf{7 0 3}$ psia pressure set point two-open-path-model

1.6 The relief valve position and cold leg pressure for a position changing rate based on $10 \mathrm{~ms}$ opening or closing time and 703 psia pressure set point - two-open-path-model

1.7 The flow rate $\mathrm{m}^{3} / \mathrm{s}$ through the relief valve for a position changing rate based on $10 \mathrm{~ms}$ opening or closing time and 703 psia pressure set point - two-open-path-model 


\section{viii \\ LIST OF FIGURES (costinued)}

Figure

Page

1.8 The relief valve exit (back) pressure for a position changing rate based on $10 \mathrm{~ms}$ opening or closing time and 703 psia pressure set point - two-open-path-model .................... 75

1.9 The relief valve position for a position changing rate based on $20 \mathrm{~ms}$ opening or closing time and 703 psia pressure set point - one-open-

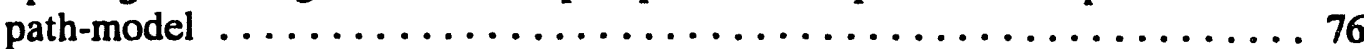

1.10 The relief valve position and the cold leg pressure for a position changing rate based on $\mathbf{5 0}$ ms opening or closing time and 703 psia pressure set point - one-open-path-model

1.11 The relief valve position for a position changing rate based on $1 \mathrm{~ms}$ opening or closing time and 703 psia pressure set point one-open-path-mode $\ldots \ldots \ldots \ldots \ldots \ldots \ldots \ldots \ldots \ldots \ldots$

1.12 The relief valve flow rate in gpm for a position changing rate based on $1 \mathrm{~ms}$ opening or closing time and 703 psia pressure set point one-open-path-model

1.13 The pressures at the inlet of the relief valve and $11 / 2$ in. pipe, and the cold leg for a position changing rate based on $1 \mathrm{~ms}$ opening or closing time and 703 psia pressure set point - onc open-path-model ........80

2.1 The relief valve position and the cold leg pressure for a position changing rate based on $10 \mathrm{~ms}$ opening or closing time, 703 psia pressure set point and cold leg pressurization rate 80 psits one-open-path-model

2.2 The pressures at the inlet of relief valve and 11/2 in. pipe and the cold leg for a position changing rate based on $10 \mathrm{~ms}$ opening or closing time, 703 psia pressure set point and a cold leg pressurization $80 \mathrm{psi} / \mathrm{s}$ one-open-path-model

2.3 The relief valve position and the cold leg pressu ie for a position changing rate based on $10 \mathrm{~ms}$ opening or closing time, 703 psia pressure set point and cold leg pressurization rate 1500 psits one-open-path-model 
LIST OF FIGURES (continued)

Figure

Page

2.4 The relief valve position and the cold leg pressure for a position changing rate based on 10 ms opening or closing time, 703 psia pressure set point and cold leg pressurization rate $18000 \mathrm{psi} / \mathrm{s}$ one-open-path-model $\ldots \ldots \ldots \ldots \ldots \ldots \ldots \ldots \ldots \ldots \ldots \ldots$

3.1 The relief valve position and the cold leg pressure for a position changing rate based on $\mathbf{1 0} \mathrm{ms}$ opening or closing time and 703 psia pressure set point - two-path-model with one path always closed . . . . . 87

3.2 The relief valve flow rate in gpm for a position changing rate based on $10 \mathrm{~ms}$ opening or closing time and 703 psia pressure set point two-path-model with one path always closed 88

3.3 The pressures at the cold leg and $11 / 2$ in. pipe for a position changing rate based on $10 \mathrm{~ms}$ opening or closing time and 703 psia pressure set point - two-path-model with one path always closed . . . . . . 89

3.4 The relief valve inlet pressure for a position changing rate based on 10 ms opening or closing time and 703 psia pressure set point two-path-model with one path always closed

3.5 The closed relief valve inlet pressure for a position changing rate based on $10 \mathrm{~ms}$ opening or closing time and 703 psia pressure set point two-path-model with one path always closed

4.1 The relief valve positions for position changing rates based on 10 and 20 ms opening and closing times and 703 and 708 psia pressure set points respectively two-open-path-model

4.2 The pressures at the cold leg, at the inlet of $11 / 2$ in. pipe, and the inlet of the valves, and relief valve positions for position changing rates based on 10 and 20 ms opening and closing times and 703 and 708 psia pressure set points respectively - two-open-path-model

4.3 The pressures at the inlet of the valves and relief valve positions for position changing rates based on 10 and $20 \mathrm{~ms}$ opening and closing times and 703 and 708 psia pressure set points respectively during the first $0.1 \mathrm{~s}$ - two-open-path-model 


\section{LIST OF FIGURES (continued)}

Figure

Page

4.4 The pressures at the inlet and exit of the valves and relief valve positions for position changing rates based on 10 and $20 \mathrm{~ms}$ opening and closing times and 703 and 708 psia pressure set points respectively during the first $0.1 \mathrm{~s}$ - two-open-path-model $\ldots \ldots \ldots \ldots \ldots$

4.5 The flow rates in gpm through the relief valves and main discharge piping for position changing rates based on 10 and $20 \mathrm{~ms}$ opening and closing times and 703 and 708 psia pressure set points respectively during the first $0.1 \mathrm{~s}$ - two-open-path-model

4.6 The flow rates in $\mathrm{m}^{3} / \mathrm{s}$ through the relief valves and main discharge piping for position changing rates based on 10 and $20 \mathrm{~ms}$ opening and closing times and 703 and 708 psia pressure set points respectively during the first $0.1 \mathrm{~s}$ - two-open-path-model $\ldots \ldots \ldots \ldots \ldots \ldots \ldots \ldots \ldots$

4.7 The relief valve positions for position changing rates based on 10 and $10 \mathrm{~ms}$ opening and closing times and 703 and 703 psia pressure set points respectively two-open-path-model

4.8 The pressures at the cold leg, at the inlet of $11 / 2$ in. pipe and the relief valve, and relief valve position for position changing rate based on $10 \mathrm{~ms}$ opening and closing times and 703 psia pressure set point two-open-path-model

4.9 The flow rates in gpm through the relief valves and main discharge piping for position changing rates based on 10 and $10 \mathrm{~ms}$ opening and closing times and 703 and 703 psia pressure set points respectively

- two-open-path-model

4.10 The flow rates in $\mathrm{m}^{3} / \mathrm{s}$ through the relief valves and main discharge piping for position changing rates based on 10 and $10 \mathrm{~ms}$ opening and closing times and 703 and 703 psia pressure set points respectively

- two-open-path-model

5.1 The relief valve position for a position changing rate based on $10 \mathrm{~ms}$ opening or closing time and $\mathbf{7 0 3}$ psia pressure set point - one-open-path with back pressure model $\ldots \ldots \ldots \ldots \ldots \ldots \ldots \ldots \ldots \ldots \ldots \ldots \ldots$

5.2 The relief valve inlet pressure for a position changing rate based on $10 \mathrm{~ms}$ opening or closing time and 703 psia pressure set point - one-open-path with back pressure model 
$\mathbf{x i}$

\section{LIST OF FIGURES (continued)}

Fipure

Page

5.3 The relief valve opening pressure as a function of back pressure for a position changing rate based on $10 \mathrm{~ms}$ opening or closing time and 703 psia set point pressure

5.4 The main downstream piping inlet and outlet flow rates for a position changing rate based on $10 \mathrm{~ms}$ opening or closing time and 703 psia pressure set point - one-open-path with back pressure model ............................... 110

5.5 The inlet and discharge pressures of the relief valve and valve position for a position changing rate based on $10 \mathrm{~ms}$ opening or closing time and 703 psia pressure set point - one-open-path with back pressure model 
xii

LIST OF TABLES

Table

Page

1 Measured blowdown vaiues vs pressure drops for different upstream piping configuration ${ }^{4} \ldots \ldots \ldots \ldots \ldots \ldots \ldots \ldots \ldots \ldots \ldots \ldots \ldots \ldots \ldots \ldots \ldots \ldots$

2 Opening pop and valve closing times for steam flow ${ }^{10} \ldots \ldots \ldots \ldots \ldots 11$

3 Opening pop and valve closing times for water and steam flow through

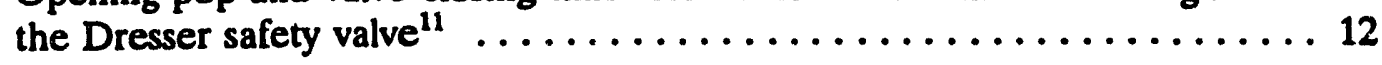

4 Opening pop and valve closing times for water and steam flow through

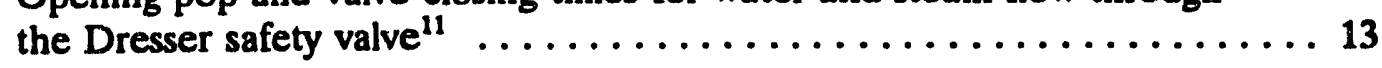

5 Opening pop and valve closing times for steam flow through the Crosby

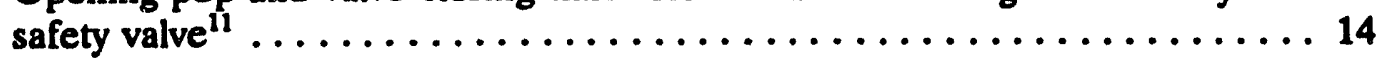

6 Opening pop and valve closing times for steam and water flow through the Crosby safeiy valve ${ }^{11} \ldots \ldots \ldots \ldots \ldots \ldots \ldots \ldots \ldots \ldots \ldots \ldots \ldots$

7 Opening pop and valve closing times for steam flow through the Crosby

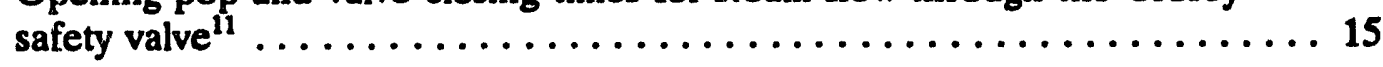

8 The maximum values of the several system variables for case $1 \mathrm{a} 1 \ldots \ldots 28$

9 The maximum values of the several system variables for case $3 \mathrm{a} 1 \ldots \ldots 32$

10 The maximum values of the several system variables for case $3 b 1 \ldots 37$

11 The maximum values of the several system variables for case $3 \mathrm{a} 2 \ldots \ldots$

12 The maximum values of the several system variables for case $3 \mathrm{~b} 2 \ldots \ldots$

13 The maximum inlet plenum pressures and relief valve flow rates for cases $3 \mathrm{~b} 2 \mathrm{a} 7,3 \mathrm{~b} 2 \mathrm{~b} 7$, and $3 \mathrm{~b} 2 \mathrm{c} 7 \ldots \ldots \ldots \ldots \ldots \ldots \ldots \ldots \ldots \ldots \ldots$

14 The maximum values of the several system variables for case $3 b 2 k w \ldots 61$

15 The relief valve subsystem models $\ldots \ldots \ldots \ldots \ldots \ldots \ldots \ldots \ldots$

16 Different cold leg pressurization rates and corresponding valve opening times 
xiii

\title{
ANALYSIS OF RELIEF VALVE PERFORMANCE AND STABIITTY \\ AND \\ PRESSURIZER PUMP OVERSPEED TRANSIENTS
}

\author{
Michael C. Sozer
}

\begin{abstract}
The pressurizer pump overspeed transients at the High Flux Isotope Reactor (HFIR) fall in the category of "increase in coolant inventory transients." They are among the accident transients to be performed for Chapter 15 of the HFIR safety analysis report (SAR). The pressurizer pump speed starting to increase inadvertently to reach its maximum speed of $3560 \mathrm{rpm}$ while the reactor operates under normal conditions is the cause of this transient. Increased primary coolant system pressure due to increased pressurizer pump flow into the primary coolant head tank challenges the relief valves to open. If the relief valves do not open, increased primary coolant system pressure will challenge the integrity of the high pressure boundary.

Two sets of analyses were performed to analyze the pressurizer pump overspeed transients. The purpose of the first analysis is to estimate how long it will take for the relief valves to open under different conditions and whether or not they will chatter or flutter for a considerable amount of time. The analysis estimates relief valve performance and stability using four different relief valve subsystem models. The models include the upstream and downstream piping so that effects of the piping on valve performance and stability can be estimated under different conditions such as varying opening and closing rates, set points, one or two rupture disk - relief valve paths being available, and different cold leg pressurization rates. The relief valve subsystem models are not attached to the primary coolant system model. The primary coolant system pressure is represented as a boundary condition and input to the program.
\end{abstract}

Vigorous pressure oscillations were produced in all of the computations performed as part of the first analysis. These waves cause the relief valve to open much later than the preassigned opening time as the valve position responds to increasing and decreasing inlet pressure around the set point. However, the relief valve was able to fully open in $<1 \mathrm{~s}$ in all of the cases analyzed. Since it takes about $10 \mathrm{~s}$ for the pressurizer pump to achieve its maximum speed, $<1 \mathrm{~s}$ opening time may be tolerated without a significant level of concern.

The second analysis includes new simulations of the pressurizer pump overspeed transients that were previously simulated using the RELAP5 thermal-hydraulic computer code. The HFIRSYS, High Flux Isotope Reactor System Transient Analysis computer code, was utilized for these simulations providing referable results for comparisons. The increased pressurizer pump flow due to runaway pressurizer pump speed pressurizes the primary coolant system. The assumptions were made in such a way to form constraining conditions at initiation of and during the transients to generate as high an overpressure situation as 
xiv

possible. The system was intentionally put under stress. Only one relief valve was assumed to open. Amon ; the transients that were simulated, the one with the disabled high discharge and low suction pressure trips of the pressurizer pump was considered to be the most serious transient because the system remains at high pressure while the relief valve stays open. The open relief valve was able to keep the system pressure close to the pressure set point of the relief valve.

For the same transient mentioned in the preceoing paragraph, effects of the different valve characteristics on the maximum primary coolant system pressure were investigated by assuming that open relief valve remains at a half open position (fluttering). The results indicate that the maximum pressure rise is a strong function of valve characteristics. The highest rise in the primary coolant system pressure which was $>300$ psi above the relief valve opening pressure occurred when the equal percentage characteristics were used. The quick opening characteristic that allow high flow rates helps the system keep its pressure around the set point pressure of the relief valves. The primary system pressure may be reduced to normal levels through desirable operator actions. If no proper action is taken, the pressurizer pump will continue running while the system is at high pressure. Eventually, the primary coolant head tank water level will decrease down to $25 \%$ capacity and cause the pump trip. If the block valves take $4 \mathrm{~s}$ to close, a reactor trip and following the reactor trip the main secondary coolant pump trip will occur.

The results of the HFIRSYS pressurizer pump overspeed transient simulations indicate that at least one relief valve must be fully open after the rupture disk is ruptured in order to prevent the primary coolant system pressure from rising above the set point pressure of the relief valves. There are two rupture disk - relief valve paths at HFIR. 


\section{INTRODUCTION}

The HFIR is a research reactor designed to generate high thermal neutron fluxes $\left(4 \times 10^{15}\right.$ neutrons $\left.\mathrm{cm}^{-2} \mathrm{~s}^{-1}\right)$ originally at $100 \mathrm{MW}$. The reactor currently operates at $85 \mathrm{MW}$. HFIR is a pressurized light water moderated and cooled research reactor and does not generate electricity. The reactor vessel is under water and the primary coolant system is pressurized by the pressurizer pump, unlike commercial pressurized water reactors (PWRs) that have pressurizers. The reactor core is composed of 540 fuel plates distributed among two concentric annular regions. It has a height of $24 \mathrm{in.}$ and a diameter of $17.1 \mathrm{in}$. The primary purpose of HFIR is to produce trans-plutonium isotopes for use in the heavy element research programs and also to provide on site experimental facilities for research.

The construction of HFIR was completed in 1965. It had been operated until it was shut down in November 1986 due to concerns mainly over increased pressure vessel embrittlement. Restart activities concerning various aspects of HFIR were undertaken starting in November 1986. The operational conditions were redefined (85 MW and 482.7 psia), ${ }^{2}$ and HFIR was restarted at low power in April 1989.

As part of the restart activities, the HFIRSYS computer code for HFIR system transient analysis studies including small break loss of coolant accidents and operational transients was developed. The HFIRSYS model is based on the Modular Modeling System (MMS) computer code (Version 2, 1986) whose development was sponsored by Electric Power Research Institute (EPRI). The MMS computer code is based on Advanced Continuous Simulation Language (ACSL), a FORTRAN-based flexible simulation environment for dynamic systems analysis, heat transfer, fluid flow, and control system studies. The heat generation in the core is represented using steady state and decay heat power profiles. The reactor, core, heat exchangers, and circular and horizontal water tank models were developed in house. The original MMS pipe modules had to be modified to include structural expansion and contraction due to pressurization and depressurization of the primary coolant system. The control system model including various trips is implemented into HFIRSYS. The secondary coolant system is represented by the flows in and out of the heat exchangers.

Separate from HFIRSYS, independent relief valve subsystem models were developed in order to study relief valve stability and performance during high pressure coolant discharges. The cold leg, to which the upstream piping of the rupture disk - relief valve path attached, is represented as a boundary condition. The subsystem models are composed of relief valve upstream and downstream piping, primary coolant storage tank, and the relief valves. The valve position changing rates, calculated based on available data on the opening time of the industrial relief and safety valves, is a constant and input to the model. The main purpose of the calculations is to discern whether or not the relief valves stay in stable fully open position and how long they take to reach to that state. Various calculations were performed to analyze effects of different factors. The results point at relief valve opening times that are $<1 \mathrm{~s}$ in all cases. 
Transients due to pressurizer pump overspeed are simulated using HFIRSYS. Different scenarios are designed around failed pressurizer pump high discharge pressure trip, failed low suction pressure trip, failed high discharge and low suction trips, and all mitigating equipment being available. The results of the simulations indicate that at least one relief valve has to be fully open after the rupture disk is ruptured in order to prevent the primary coolant system pressure from climbing above the relief valve set point pressure. There are two rupture disk - relief valve paths at HFIR. The rupture disk in the open path was assumed to be ruptured previous to the opening of the relief valve in the calculations.

The decision to use English units in this report was made since they were used in HFIR design, engineering drawings, and most analyses performed. 


\section{PRESSURE RELIEF SUBSYSTEM}

The HFIR pressure relief system is composed of the relief valves, rupture disks, the vent isolation valves and the pressure relief subsystem piping, the rupture disk/relief cavity pressure monitors ${ }^{1}$ and the primary coolant storage tank. A schematic drawing of the pressure relief system is shown in Fig. $1 .^{1}$ The pressure relief system protects the reactor against over pressurization (vessel design pressure is $1000 \mathrm{psig}$ ). The maximum allowable peak pressure is 689 psig (703.7 psia). The downstream piping (4 in. sch 40, stainless steel) of the rupture disks and the relief valves are connected to the underground primary coolant storage tank that is large enough to hold the entire primary coolant inventory. The storage tank pressure is atmospheric. The relief valves (PSV 150 and 157 in Fig. 1) and rupture disks (reverse buckling) are stainless steel. The inlet piping of the rupture disks and the relief valves comes out of the primary cooling system with a stainless steel 4 in. sch 40 pipe and bifurcates into (1 1/2 in. sch 40, stainless steel) relief paths at the inlet of the rupture disk relief valve paths. The region between the rupture disk and the relief valve is monitored. If it exceeds 44.7 psia indicating considerable leakage through the rupture disk, the reactor is to be shut down.

There are no safety-related or supplemental operator actions associated with the pressure relief system. The runaway pressurizer pump speed event introduces the largest overpressure challenge to the integrity of the high pressure boundary.

The rupture discs are rated at a burst pressure equal to

$$
650 \pm 5 \% \text { psig or } 650 \pm 32.5 \text { psig. }
$$

The maximum rupture disc burst pressure is $682.5 \mathrm{psig}$ (697.2 psia). The set pressure for the relief valves is

$$
625 \pm 3 \% \text { psig or } 625 \pm 18.75 \text { psig }
$$

or in terms of absolute pressure (psia) it is

$$
639.7 \pm 18.75 \text { psia. }
$$

Each of the two relief valve rupture disc paths has a capacity of $296 \mathrm{gpm}$ at a $10 \%$ overpressure of $682 \mathrm{psi}(1.1 \times 620 \mathrm{psi})$ and including the rupture disc multiplication factor. ${ }^{1}$ (The flow rate through the valve was multiplied by 0.8 in order to account for the rupture disc.) The limiting safety system setting (LSSS) in technical specifications for the relief valve setting is $689 \mathrm{psig}(650 \times 1.06=689)$. (The uncertainty value $6 \%$ comes from the manufacturer's catalog.) 


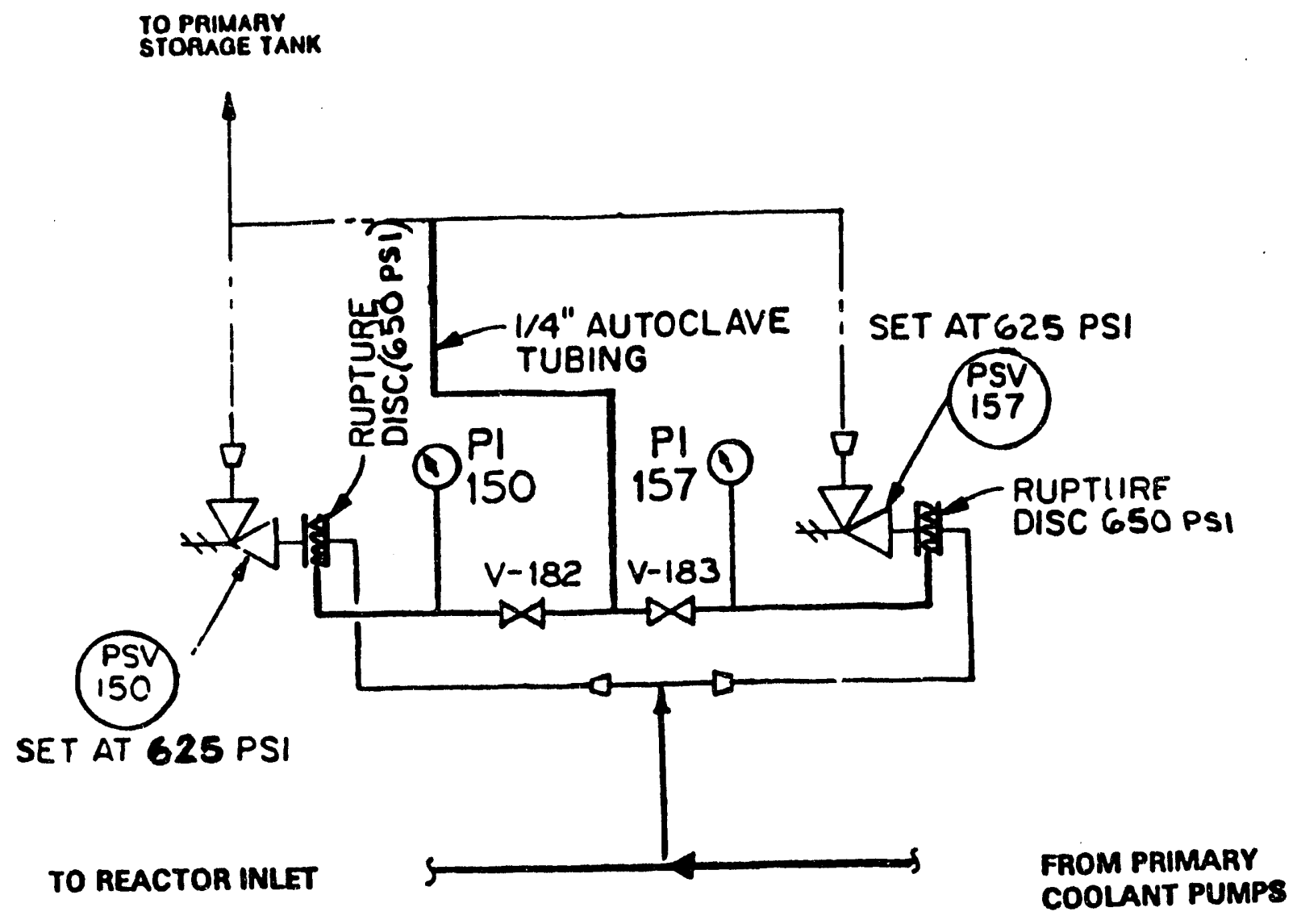

Fig. 1. HFIR Pressure Relief System - Process Flow Diagram. 


\section{RELIEF VALVES AND MODELING CONSIDERATIONS}

This section provides a brief description of the basic physics involved in relief valve operations and effects of the related components such as upstream and downstream pipes on valve performance and stability.

\subsection{SAFETY VALVES AND RELIEF VALVES}

Safety valves are distinguished from relief valves in Ref. 2 in the following manner.

Safety valves: The Crosby and Dresser safety valves are direct acting spring loaded safety valve design. A variety of combinations of inlet, outlet, and orifice sizes are used. Target Rock Corporation model is a pilot operated valve design actuated by the system inlet pressure. $^{2}$

Relief valves: The Crosby Valve and Gage Company model is electrically actuated pilot operated valve design. The Copes-Vulcan model is air operated globe valve design. The Control Components model is an air operated globe valve design. ${ }^{2}$

These descriptions qualifies the HFIR relief valves as being in the category of safety valves, although we will continue to refer to them as "relief valves."

\subsection{STABILITY OF A COUPLED SAFETY VALVE-PIPING SUBSYSTEM}

\section{Effects of Upstream Piping}

Most safety valves, spring loaded and self-actuated, are designed to open and close with a pop action. The quickness of the valves results in pressure waves. The pressure waves and frictional pressure drop in the inlet piping may result in decrease in stability of the valves during opening and closing. EPRI safety valve test data has shown that the upstream pipe configuration may strongly influence the valve performance and stability. Long inlet pipes in general cause decreased valve stability and vice versa. ${ }^{3}$

Safety valves are designed to open and close in about $0.05 \mathrm{~s}$. Due to sudden expansion when the valve opens, an expansion wave (low pressure) is generated. The pressure at the inlet of the valve suddenly decreases and the relief valve may start closing if the pressure is low enough. The wave travels to the vessel and returns as a compression wave (high pressure). ${ }^{3}$ The increased pressure at the inlet of the relief valve causes the valve to start opening. Effects of six different inlet piping configurations for the same valve were studied (Zahorsky). ${ }^{4}$

here.

Some helpful definitions are provided by Zahorsky. These definitions are repeated 
Value blowdown: Blowdown is defined as the difference between the actual popping pressure and actual reseating (final closing) pressure expressed as a percent of the set pressure or in pressure units (psi). (The guide ring, adjusting ring, and nozzle ring are primarily used to control valve blowdown. The guide ring allows changing the discharge flow area.)

Chatter: Chatter, as defined by ANSI B95.1, is an abnormal rapid reciprocating motion of the movable parts of the pressure relief valve in which the disc contacts the seat.

Flutter: Flutter is an abnormal rapid reciprocating motion of the movable parts of the pressure relief valve in which the disc does not contact the seat.

The results in the following table clearly indicate the effect of the pressure drop on valve blowdown. The test objective blowdown was about 4.0 to $4.5 \%$. The relief valve used in the tests had a flow cross sectional area equal to about 2 in. Flutter and chatter were observed with greater blowdowns of those configurations as indicated in Table $1 .^{4}$

Table 1. Measured blowdown values vs pressure drops for different upstream piping configuration"

\begin{tabular}{|c|c|c|c|}
\hline Configuration & Diameter and length of inlet line & $\begin{array}{l}\text { Measured } \\
\text { steady-state } \\
\text { pressure } \\
\text { drop } \\
\text { (psi) }\end{array}$ & Blowdown, \% \\
\hline $\begin{array}{l}1 \\
2 \\
3 \\
4 \\
5\end{array}$ & $\begin{array}{l}D_{i}=2 \text { in., } L=21 / 4 \text { in., straight } \\
D_{i}=2 \text { in., } L=151 / 2 \text { in., straight } \\
D_{i}=2 \text { in., } L=361 / 4 \text { in., straight } \\
D_{i}=2 \text { in., } L=73 \text { in., } \\
D_{i}=2 \text { in., } L=? \\
D_{i}=6 \text { in., } L=\text { Straight }\end{array}$ & $\begin{array}{l}33 \\
33 \\
43 \\
58 \\
52 \\
32\end{array}$ & $\begin{array}{l}3.5,3.9 \\
3.9 \\
5.6 \\
8.4 \\
8.0,8.3 \\
4.3\end{array}$ \\
\hline
\end{tabular}

The test results showed that the increase in steady-state inlet frictional pressure drop has an impact on the achievable blowdown for a safety valve. The minimum achievable blowdown is directly related to pressure drop in the inlet piping; however, there are other factors that also influence valve performance. For inlet piping designs with excessive pressure drop and configurations that are widely different from the recommended codes in ASME Section I, degraded valve performance may occur. 


\subsection{Effects of Downstream Piping}

After the valve opens, the fluid flowing into the discharge pipe gradually rises the pressure in the downstream portion of the relief valve. The magnitude of the back pressure depends on the configuration of the downstream piping, length, and diameter. The delay for downstream pressure rise provides stability to the valve. ${ }^{3}$

\subsubsection{Instability During Opening}

The maximum upstream pressure rise $\mathrm{h}_{\max }$ in $\mathrm{ft}$ above the normal pressure in a pipe due to sudden closure of a valve is given by the Joukowsky's Law

$$
\mathrm{h}_{\max }=\mathrm{a} \frac{\mathrm{V}_{\mathrm{o}}}{\mathrm{g}}
$$

where

$$
\begin{aligned}
\mathrm{a} & =\text { speed of sound in the fluid }(\mathrm{ft} / \mathrm{s}) \\
\mathrm{V}_{\mathrm{o}} & =\text { velocity of the fluid before closure }(\mathrm{ft} / \mathrm{s}), \text { and } \\
\mathrm{g} & =\text { gravitational acceleration }\left(\mathrm{ft} / \mathrm{s}^{2}\right) .
\end{aligned}
$$

Similarly, the magnitude of the upstream pressure increases or decreases due to change in the velocity of the fluid can be calculated from

$$
P_{\text {wave }}=a \rho\left(V_{0}-V_{f}\right) \frac{1}{144 g_{c}}
$$

where

$$
\begin{aligned}
\mathrm{P}_{\text {wave }} & =\text { pressure wave strength }(\mathrm{psi}) \\
\rho & =\text { liquid water density }\left(\mathrm{lb}_{\mathrm{m}} / \mathrm{ft}^{3}\right), \\
\mathrm{V}_{\mathrm{f}} & =\text { final velocity }(\mathrm{ft} / \mathrm{s}), \text { and } \\
\mathrm{g}_{\mathrm{c}} & =32.1739 \mathrm{lb}_{\mathrm{m}} \mathrm{ft} / \mathrm{lb} \mathrm{b}_{\mathrm{f}} \mathrm{s}^{2} .
\end{aligned}
$$

Combined magnitude of the pressure wave and pressure drop generated during the opening of a valve may be low enough not to allow the valve open fully $\left(\operatorname{Singh}^{3}\right)$. The relief valve may start closing resulting in an increase in inlet pressure. These oscillations of the inlet pressure may cause fluttering. The exact nature of interactions will depend on inlet pipe configuration, length, diameter, and inherent valve stability. The back pressure will also have effect on these interactions. For the valve to remain open, the vessel pressure minus the pressure drop due to expansion of the fluid (expansion wave, $P_{\text {wave }}$ ) when the valve opens and minus friction pressure drop in the inlet pipe $\left(\mathrm{P}_{\text {fric }}\right)$ should be greater than initial closure pressure $P_{i c}$ in Fig. 2. The initial closure pressure $\left(P_{i c}\right)$ while there is flow through the valve is different from the original pop open pressure. As long as the valve inlet pressure is larger than the initial closure pressure, the valve stays open. The stability criterion $\left(\right.$ Singh $\left.^{3}\right)$ is 


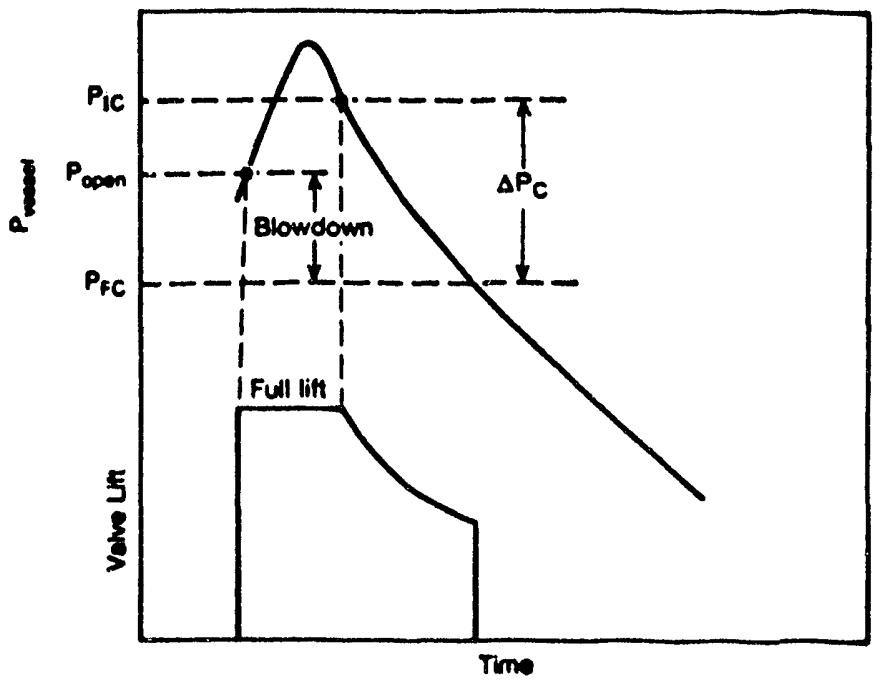

Fig. 2 Relief valve position vs pressure reproduced from Ref. 3. 


$$
P_{\text {open }}-P_{\text {wave }}-P_{\text {fric }}>P_{\text {ic }} \text {, }
$$

$\mathbf{P}_{\text {open }}$ appears to be the pop-open pressure. If $\mathrm{P}_{\text {open }}$ as defined in Fig. 1 of the Singh's ${ }^{3}$ paper, (included as Fig. 2 in this report), is used, it is not plausible how

$$
P_{\text {open }}-P_{\text {wave }}-P_{\text {fric }}
$$

can be larger than the initial closure pressure, since $P_{i c}$ in Fig. 2 is larger than $P_{\text {open }}$ to start with. The final closure pressure $\left(P_{f c}\right)$ is lower than both the initial closure pressure and $P_{\text {open }}$. The magnitude of $P_{\text {open }}$ may change due to thermal and seat wear effects. ${ }^{3}$ The inconsistency may be due to nomenclature errors. However, for stability, $P_{\text {vessel }}-P_{\text {wave }}-P_{\text {fric }}$ has to be larger than the pressure $\left(\mathrm{P}_{\mathrm{ic}}\right)$ at which the valve starts closing as indicated in Fig. 2.

\subsubsection{Instability During Closing}

Combined magnitude of the pressure wave and the pressure rise (i.e., pressure drop due to friction recovered when the flow becomes zero) may be high enough to cause the valve reopen after it closes. ${ }^{3}$ On reopening upstream pressure may drop below initial closing pressure point causing the valve start reclosing (i.e., causing it to cycle). The stability criterion for the valve to remain open during closure is

$$
P_{\text {fc }}+P_{\text {wave }}+P_{\text {fric }}<P_{\text {open }}
$$

where it is implicit that $\mathbf{P}_{\text {vessel }}$ should be equal to or larger than $P_{\text {open }}$ and $P_{f c}$ corresponds to the final closure pressure as shown in Fig. 2.

The final closure pressure corresponds to the complete closure of the valve. It is smaller than initial closure pressure $P_{\text {ic }}$ at which the valve starts closing. The difference between $P_{\text {open }}$ and $P_{f c}$ is called "blowdown." The blowdown is also defined with respect to a reference pressure minus $P_{f c}$. The percent blowdown is the ratio of the difference between $P_{\text {open }}$ and $P_{\text {fc }}$ to $P_{\text {open }}{ }^{3}$

\subsection{Effects of Guide Ring Settings, Spring Forces, and Back Pressure}

By changing the geometry of the flow passage within the valve (valve flow exit region), the guide ring setting influences blowdown ratio and valve stability. ${ }^{6-8}$ A schematic drawing of a typical relief valve in the closed position is shown in Fig. 3. The blowdown is strongly affected by the back pressure and spring stiffness also. ${ }^{6}$ Using the test data produced by the EPRI, correlations were developed for predicting blowdown as a function of the adjusting ring settings for similar valves. ${ }^{6}$ There is a body bowl (chamber) region acting as a small reservoir between the inlet and outlet of the valve. The back pressure and the body bowl pressure are strongly associated with each other and both names are interchangeably used. ${ }^{6}$ The pressure on the portion of the upper surface of the disk that is in contact with the fluid and the pressure applied to the lower surface of the disk due to the valve inlet and discharge (outlet) pressures act against each other. The valve discharge or outlet pressure is affected by the downstream piping and its configuration. The body bowl pressure is correlated with the back 


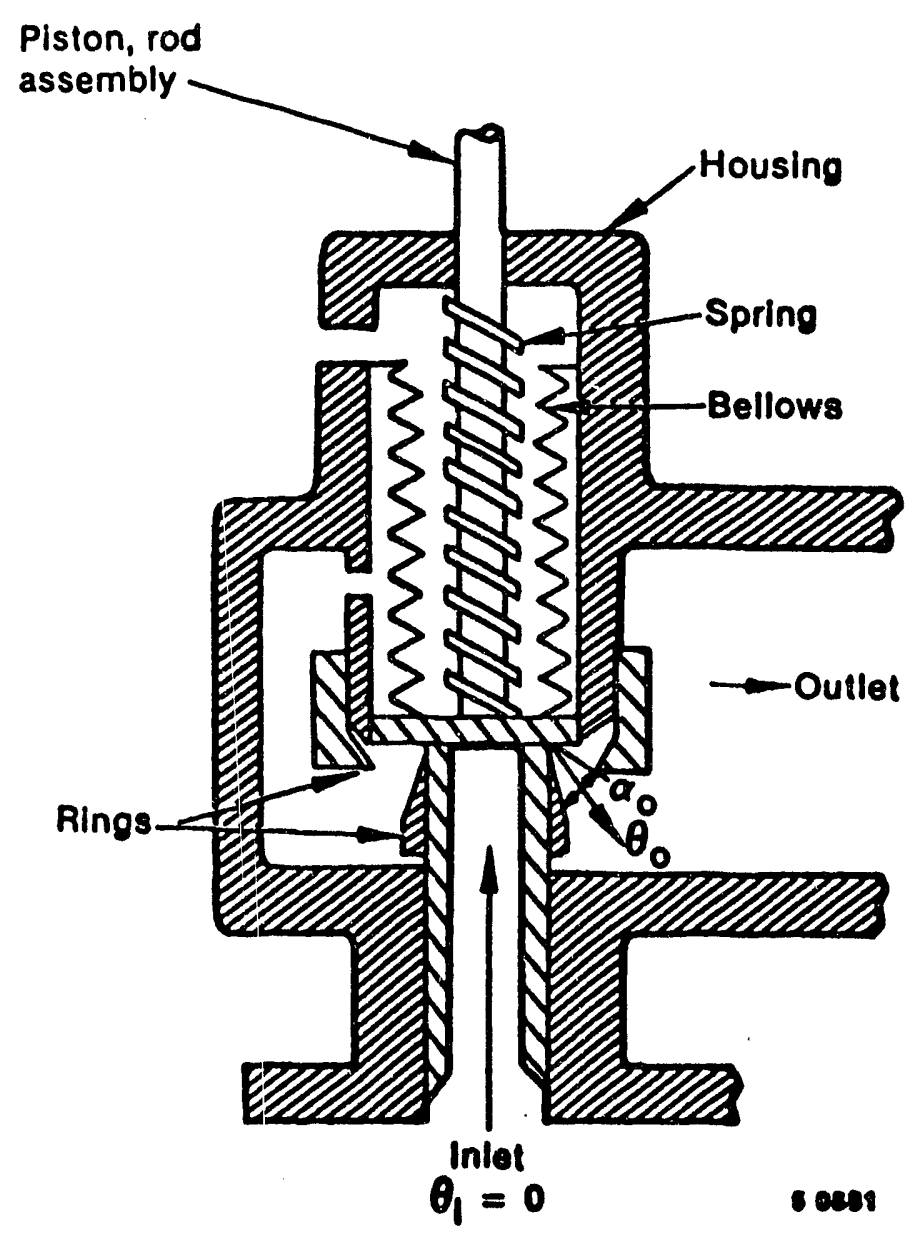

Fig. 3. Schematic of a typical relief valve in the closed position reproduced from: REILAPSMOD2 Code Manual Volume 1: Code Structure, Systems Modek, and Solution Methods NUREG/CR-4312, Aug. 1985. 
pressure in the same way: based on upstream stagnation pressure and valve outlet pressure (experimental data) for steam flow through different valves. ${ }^{6.7}$ A numerical sensitivity study indicates that lowering the guide ring position increases the blowdown ratio. ${ }^{8}$ The blowdown ratio can also be reduced by reducing the back pressure or making the spring softer according to the same study. ${ }^{8}$ The guide rings are referred to as nozzle rings placed around the inlet nozzle and adjusting rings placed around the housing of the valve stem. The rings can be adjusted to control the flow area through which the flow exits into the body bowl region from the inlet nozzle region.

In a different study, the RELAP5/MOD1 thermal-hydraulic code along with a relief valve model including the effects reported in the preceding paragraph was used to calculate the response of a PWR pressurizer safety valve during a saturated steam discharge transient and a water seal discharge transient. ${ }^{9}$ Comparisons between the experimental data and the results of the calculations were satisfactory for both, the steam and water transients. During the water flow transients, the valve stem oscillations reached about $200 \mathrm{~Hz}$ and pressure oscillations were larger than 2000 psi.

\subsubsection{Relief Valve Opening and Closing Times}

The experimental data about relief valves opening and closing times are reported in the literature. The data about relief valves in Table 2 were extracted from Ref. 10 . The available opening and closing times, names of the valve manufacturers, type of fluid, and page numbers are provided.

Table 2. Opening pop and value closing times for steam flow 10

\begin{tabular}{lccc}
\hline Opening pop time & $\begin{array}{c}\text { Valve } \\
\text { closing time }\end{array}$ & Fluid & Reference \\
\hline $0.01 \mathrm{~s}$ & - & - & p. 7 (Ref. 10) \\
$0.01 \mathrm{~s}$ (Crosby) & - & steam & p. 19 (Ref. 10) \\
$0.015 \mathrm{~s}$ (Dresser) & - & steam & p. 19 (Ref. 10) \\
$0.03 \mathrm{~s}$ (Fig. 2a) & $-\overline{0}$ & - & p. 32 (Ref. 10) \\
$<0.05 \mathrm{~s}$ & $0.067 \mathrm{~s}$ & - & p. 30 (Ref. 10) \\
$0.006 \mathrm{~s}$ & $0.010 \mathrm{~s}$ & steam & p. 34 (Ref. 10) \\
$0.014 \mathrm{~s}$ & - & steam & p. 34 (Ref. 10) \\
$<0.03 \mathrm{~s}$ (Fig. 7) & & & p. 82 (Ref. 10) \\
\hline
\end{tabular}

The EPRI performed tests and reported data on relief valves ${ }^{11}$ (EPRI PWR Safety and Relief Valve Test Program Safety and Relief Valve Test Report, NP-2628-SR, Dec. 1982). The Dresser data are the EPRI/CE safety valve test data performed for measuring valve flow performance for the Dresser 31739A safety valve. The opening pop times, therefore, refer to the same valvi.. Note that the opening pop times do not include 
opening simmer time. The page numbers as well as the fluid type are provided in Table 3 for steam and water flows.

Table 3. Opening pop and valve closing times for water and steam flow through the Dresser safety value ${ }^{11}$

\begin{tabular}{|c|c|c|c|}
\hline Opening pop time & $\begin{array}{c}\text { Valve } \\
\text { closing time } \\
\end{array}$ & Fluid & Reference \\
\hline $\begin{array}{l}0.029 \mathrm{~s} \text { (Dresser) } \\
0.040 \mathrm{~s} \text { (Dresser) } \\
0.026 \mathrm{~s} \text { (Dresser) } \\
0.034 \mathrm{~s} \text { (Dresser) } \\
0.025 \mathrm{~s} \text { (Dresser) } \\
0.034 \mathrm{~s} \text { (Dresser) } \\
0.024 \mathrm{~s} \text { (Dresser) } \\
0.012 \mathrm{~s} \text { (Dresser) } \\
0.021 \mathrm{~s} \text { (Dresser) } \\
0.015 \mathrm{~s} \text { (Dresser) } \\
0.015 \mathrm{~s} \text { (Dresser) } \\
0.013 \mathrm{~s} \text { (Dresser) } \\
0.012 \mathrm{~s} \text { (Dresser) } \\
0.016 \mathrm{~s} \text { (Dresser) } \\
0.015 \mathrm{~s} \text { (Dresser) } \\
0.016 \mathrm{~s} \text { (Dresser) } \\
0.014 \mathrm{~s} \text { (Dresser) } \\
0.016 \mathrm{~s} \text { (Dresser) } \\
0.021 \mathrm{~s} \text { (Dresser) } \\
0.007 \mathrm{~s} \text { (Dresser) } \\
0.024 \mathrm{~s} \text { (Dresser) } \\
0.024 \mathrm{~s} \text { (Dresser) } \\
0.007 \mathrm{~s} \text { (Dresser) } \\
0.011 \mathrm{~s} \text { (Dresser) } \\
0.026 \mathrm{~s} \text { (Dresser) } \\
0.013 \mathrm{~s} \text { (Dresser) } \\
0.018 \mathrm{~s} \text { (Dresser) } \\
0.043 \mathrm{~s} \text { (Dresser) }\end{array}$ & & $\begin{array}{l}\text { steam } \\
\text { steam } \\
\text { steam } \\
\text { steam } \\
\text { steam } \\
\text { steam } \\
\text { steam } \\
\text { steam } \\
\text { steam } \\
\text { steam } \\
\text { steam } \\
\text { steam } \\
\text { steam } \\
\text { steam } \\
\text { steam } \\
\text { steam } \\
\text { steam } \\
\text { steam } \\
\text { steam } \\
\text { water } \\
\text { water } \\
\text { steam } \\
\text { water } \\
\text { water } \\
\text { water } \\
\text { steam } \\
\text { steam } \\
\text { water }\end{array}$ & $\begin{array}{l}\text { p. } 3-13^{11} \\
\text { p. } 3-13^{11} \\
\text { p. } 3-13^{11} \\
\text { p. } 3-13^{11} \\
\text { p. } 3-13^{11} \\
\text { p. } 3-13^{11} \\
\text { p. } 3-13^{11} \\
\text { p. } 3-13^{11} \\
\text { p. } 3-13^{11} \\
\text { p. } 3-13^{11} \\
\text { p. } 3-13^{11} \\
\text { p. } 3-13^{11} \\
\text { p. } 3-13^{11} \\
\text { p. } 3-13^{11} \\
\text { p. } 3-15^{11} \\
\text { p. } 3-15^{11} \\
\text { p. } 3-15^{11} \\
\text { p. } 3-15^{11} \\
\text { p. } 3-15^{11} \\
\text { p. } 3-15^{11} \\
\text { p. } 3-15^{11} \\
\text { p. } 3-15^{11} \\
\text { p. } 3-15^{11} \\
\text { p. } 3-15^{11} \\
\text { p. } 3-15^{11} \\
\text { p. } 3-13^{11} \\
\text { p. } 3-15^{11} \\
\text { p. } 3-15^{11}\end{array}$ \\
\hline
\end{tabular}

The data on the EPRI/CE safety valve data for Dresser 31709NA safety valves are also provided in Ref. 11. The opening pop times do not include opening simmer times in Table 4. 
Table 4. Opening pop and value closing times for water and steam flow through the Dresser safety valve ${ }^{11}$

\begin{tabular}{|c|c|c|c|}
\hline Opening pop time & $\begin{array}{c}\text { Valve } \\
\text { closing time }\end{array}$ & Fluid & Reference \\
\hline $0.013 \mathrm{~s}$ (Dresser) & & steam & p. $3-29^{11}$ \\
\hline $0.012 \mathrm{~s}$ (Dresser) & & steam & p. $3-29^{11}$ \\
\hline $0.015 \mathrm{~s}$ (Dresser) & & steam & p. $3-29^{11}$ \\
\hline 0.017 s (Dresser) & & steam & p. $3-29^{11}$ \\
\hline $0.016 \mathrm{~s}$ (Dresser) & & steam & p. $3-29^{11}$ \\
\hline $0.018 \mathrm{~s}$ (Dresser) & & steam & p. $3-29^{11}$ \\
\hline $0.015 \mathrm{~s}$ (Dresser) & & steam & p. $3-29^{11}$ \\
\hline $0.017 \mathrm{~s}$ (Dresser) & & steam & p. $3-29^{11}$ \\
\hline $0.015 \mathrm{~s}$ (Dresser) & & water & p. $3-29^{11}$ \\
\hline $0.035 \mathrm{~s}$ (Dresser) & & water & p. $3-29^{11}$ \\
\hline $0.017 \mathrm{~s}$ (Dresser) & & water & p. $3-29^{11}$ \\
\hline $0.023 \mathrm{~s}$ (Dresser) & & steam & p. $3-29^{11}$ \\
\hline $0.059 \mathrm{~s}$ (Dresser) & & water & p. $3-29^{11}$ \\
\hline
\end{tabular}

The data on the EPRI/CE safety valve test data for the Crosby HB-BP-3K6 (steam internals) safety valve are shown in Table $5{ }^{11}$ The opening pop times do not include opening simmer times. 
14

Table 5. Opening pop and valve closing times for steam flow through the Crosby safety value ${ }^{11}$

\begin{tabular}{cccc}
\hline Opening pop time & $\begin{array}{c}\text { Valve } \\
\text { closing time }\end{array}$ & Fluid & Reference \\
\hline 0.009 s (Crosby) & steam & p. $3-43^{11}$ \\
0.006 s (Crosby) & steam & p. $3-43^{11}$ \\
0.006 s (Crosby) & steam & p. $3-43^{11}$ \\
0.007 s (Crosby) & steam & p. $3-43^{11}$ \\
0.006 s (Crosby) & steam & p. $3-43^{11}$ \\
0.006 s (Crosby) & steam & p. $3-43^{11}$ \\
0.006 s (Crosby) & steam & p. $3-43^{11}$ \\
0.007 s (Crosby) & steam & p. $3-43^{11}$ \\
0.010 s (Crosby) & steam & p. $3-43^{11}$ \\
0.008 s (Crosby) & steam & p. $3-45^{11}$ \\
0.008 s (Crosby) & steam & p. $3-45^{11}$ \\
0.006 s (Crosby) & steam & p. $3-45^{11}$ \\
0.008 s (Crosby) & steam & p. $3-45^{11}$ \\
0.007 s (Crosby) & steam & p. $3-45^{11}$ \\
0.008 s (Crosby) & steam & p. $3-45^{11}$ \\
\hline
\end{tabular}

The data on the EPRI/CE safety valve test data for the Crosby HB-BP-86-3K6 (loop seal internals) safety valve are shown in Table $6{ }^{11}$ The opening pop times do not include opening simmer times.

Table 6. Opening pop and value closing times for steam and water flow through the Crosby safety value ${ }^{11}$

\begin{tabular}{|c|c|c|c|}
\hline Opening pop time & $\begin{array}{c}\text { Valve } \\
\text { closing time }\end{array}$ & Fluid & Reference \\
\hline $\begin{array}{l}0.014 \mathrm{~s} \text { (Crosby) } \\
0.090 \mathrm{~s} \text { (Crosby) } \\
0.007 \mathrm{~s} \text { (Crosby) } \\
0.013 \mathrm{~s} \text { (Crosby) } \\
0.006 \mathrm{~s} \text { (Crosby) } \\
0.008 \mathrm{~s} \text { (Crosby) } \\
0.007 \mathrm{~s} \text { (Crosby) }\end{array}$ & & $\begin{array}{l}\text { water } \\
\text { water } \\
\text { water } \\
\text { water } \\
\text { steam } \\
\text { water } \\
\text { steam }\end{array}$ & $\begin{array}{l}\text { p. } 3-59^{11} \\
\text { p. } 3-59^{11} \\
\text { p. } 3-59^{11} \\
\text { p. } 3-59^{11} \\
\text { p. } 3-59^{11} \\
\text { p. } 3-59^{11} \\
\text { p. } 3-59^{11}\end{array}$ \\
\hline
\end{tabular}


The data on the EPRI/CE safety valve test data for the Crosby HB-BP-6M6 (loop seal internals) safety valves are shown in Table $7 .^{11}$ The opening pop times do not include opening simmer times.

Table 7. Opening pop and valve closing times for steam flow through the Crosby safety valve ${ }^{11}$

\begin{tabular}{lccc}
\hline Opening pop time & $\begin{array}{c}\text { Valve } \\
\text { closing time }\end{array}$ & Fluid & Reference \\
\hline 0.008 s (Crosby) & steam & p. $3-73^{11}$ \\
$0.012 \mathrm{~s}$ (Crosby) & water & p. $3-73^{11}$ \\
$0.014 \mathrm{~s}$ (Crosby) & water & p. $3-73^{11}$ \\
$0.011 \mathrm{~s}$ (Crosby) & water & p. $3-73^{11}$ \\
$0.016 \mathrm{~s}$ (Crosby) & water & p. $3-73^{11}$ \\
$0.017 \mathrm{~s}$ (Crosby) & water & p. $3-73^{11}$ \\
$0.009 \mathrm{~s}$ (Crosby) & water & p. $3-73^{11}$ \\
$0.013 \mathrm{~s}$ (Crosby) & steam & p. $3-75^{11}$ \\
$0.019 \mathrm{~s}$ (Crosby) & water & p. $3-75^{11}$ \\
$0.021 \mathrm{~s}$ (Crosby) & water & p. $3-75^{11}$ \\
$0.017 \mathrm{~s}$ (Crosby) & steam & p. $3-75^{11}$ \\
$0.012 \mathrm{~s}$ (Crosby) & water & p. $3-75^{11}$ \\
$0.019 \mathrm{~s}$ (Crosby) & water & p. $3-75^{11}$ \\
\hline
\end{tabular}

The same report includes more data on valve pop opening times for steam.

\subsubsection{RELAP5 Simulations of Relief Valve Performances}

Relief valve subsystems have been modelled using the RELAP5 thermal-hydraulic code. The related references are Refs. 9, 12, and 13. The RELAP5/MOD1 thermalhydraulic code along with a relief valve model was used to calculate the response of a PWR pressurizer safety valve during a saturated steam discharge transient and a water seal discharge transient. ${ }^{9}$ The same study is referenced in Sect. 3.2.5 due to relevance of the subjest and relative significance of the close agreement between the numerical and experimental results. Comparisons between the experimental data and the results of the calculations were satisfactory for both, the steam and water transients. Pressure waves at high frequencies and large amplitudes were generated in both, the calculations and experiments. For example: During the water flow experiments, the valve stem oscillations reached about $200 \mathrm{~Hz}$ and pressure oscillations were larger than 2000 psi. 


\subsubsection{Significant Factors in Modeling Relief Valves}

This section summarizes the findings in modeling of relief valve subsystems that are noted as significant factors in the open literature.

Upstream (inlet) piping: Its configuration, length, and diameter strongly affect valve performance and stability.

Downstream piping: Its configuration, length, and diameter affect the back pressure (discharge or valve exit) of the relief valve.

Opening pop time: Pressure wave generated during quick opening of the valve can cause the valve reclose. Alternating compression and expansion waves may cause valve flutter and chatter. The magnitude of pressure waves depend on opening pop time.

Closing time: Compression wave generated during closing of the valve can cause the valve reopen. Alternating compression and expansion waves can cause valve flutter and chatter. The magnitude of pressure waves depend on closing time, the smaller the closing time is higher the compression wave will be.

Guide ring settings, back pressure, and spring forces: Guide (adjusting or nozzle) ring settings can be changed to control blowdown ratio, flow rate, and back pressure. Spring forces and back pressure also affect valve performance.

Valve characteristics: For a given partial opening, the flow rate differs based on valve characteristics (linear, equal percentage, quick opening). This becomes especially significant during chatter, flutter, and flow through partially open valve. Therefore, while high flow rate close to that of full open position can be expected through a half open valve with the quick opening characteristics, only $10-20 \%$ of the full capacity may be expected through a half-open valve with the equal percentage characteristics. 


\section{HFIR SYSTEM TRANSIENT ANALYSIS MODEL AND RELIEF VALVES}

\subsection{HFIR SYSTEM TRANSIENT ANALYSIS COMPUTER CODE (HFIRSYS)}

The pressurizer pump overspeed transients were simulated using the HFIR system transient analysis computer code (HFIRSYS). Detailed information about the computer code, its theory, structure, and modules are documented in a separate report. ${ }^{15}$ The computer code is based on the MMS code which was originally developed with the support of the EPRI for system analysis of boiling and pressurized water reactors (BWRs and PWRs) as well as fossil fired plants. ${ }^{16}$ HFIRSYS mainly includes a primary coolant system, secondary flows in and out of the heat exchangers, and pressurizer pump subsystem which includes the primary coolant head tank, associated piping and the pressurizer pumps. The primary coolant system model is represented using only two heat exchanger loops as indicated in the schematic drawing of the model (Fig. 4). However, one of these loops represents two heat exchanger loops. The block diagram of the model shows all of the components, their names, and connections in Fig. 5. The cold and the hot legs are represented by the MMS pipe modules which have been modified to account for structural elasticity. The main circulation pumps and letdown valves are also MMS modules. The reactor vessel, core, and heat exchanger models were developed in house. The control system including the trips is also included in the model. HFIRSYS is used for small break loss of coolant accidents and operational transients. There is no mechanistic representation of two phase flow conditions throughout the modules; therefore, its applications are limited. The MMS PUMP4Q module includes four quadrant pump homologous curves, and torque and head multipliers for representing reduction in pump head and torque due to two-phase flow conditions. The main circulation pumps were modeled using the PUMP4Q module. Deterioration in pump head and torque due to two-phase flow conditions at the inlet of the pumps are accounted for in the model.

Validation calculations were performed and documented. ${ }^{15}$ The depressurization tests run using HFIRSYS produced satisfactory results compared to those calculated using the experimentally measured system elasticity constants. Available measured pump coastdown data were satisfactorily represented by HFIRSYS. The reactor pool check valve flow rate matches the limited amount of measured flow rate data. Additional comparisons of HFIRSYS results to those of RELAP5/MOD2.5 yield close agreement in calculated pressures and flow rates. ${ }^{17}$

\subsection{DESCRIPTION OF RELIEF VALVE SUBSYSTEM MODELS AND HFIRSYS}

The relief valve subsystem attached to HFIRSYS was modeled using only valve (MMS VALVEI) and tank models. This representation of the relief valve subsystem is different from those independent $r e$ if valve subsystem models in Sect. 6. The independent models represent the reactor inlet $q$ ing by a pressure boundary condition and include upstream and downstream stainless steel reisef valve piping. The primary coolant storage tank model keeps track of the water level and the pressure at the bottom of the tank. The piping for the relief valves was not included as separate modules in the HFIRSYS model. The inlet of the relief 
$\infty$
N
v
1
o
0
0
$\vdots$
1
$\vdots$
$\vdots$
0
0

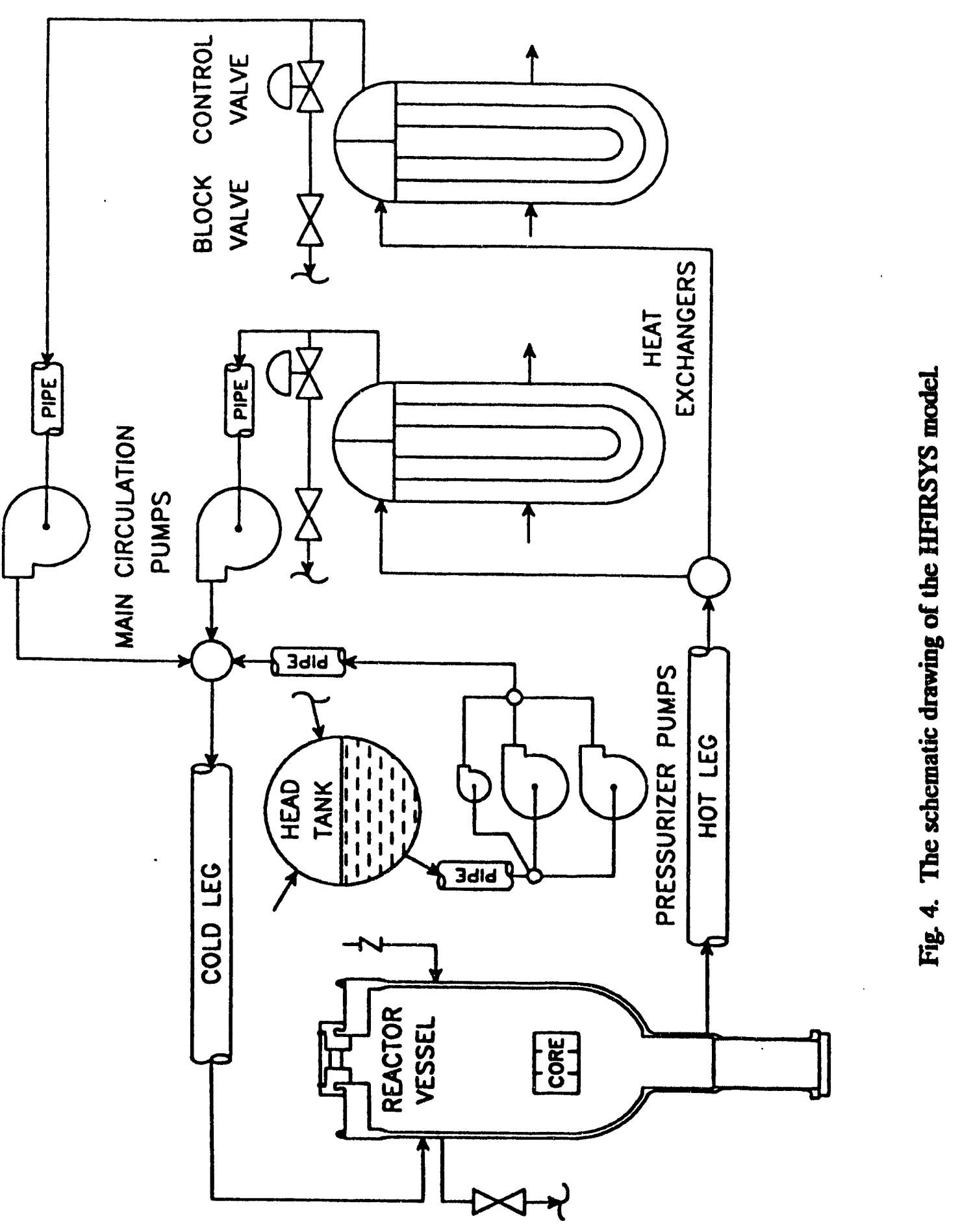




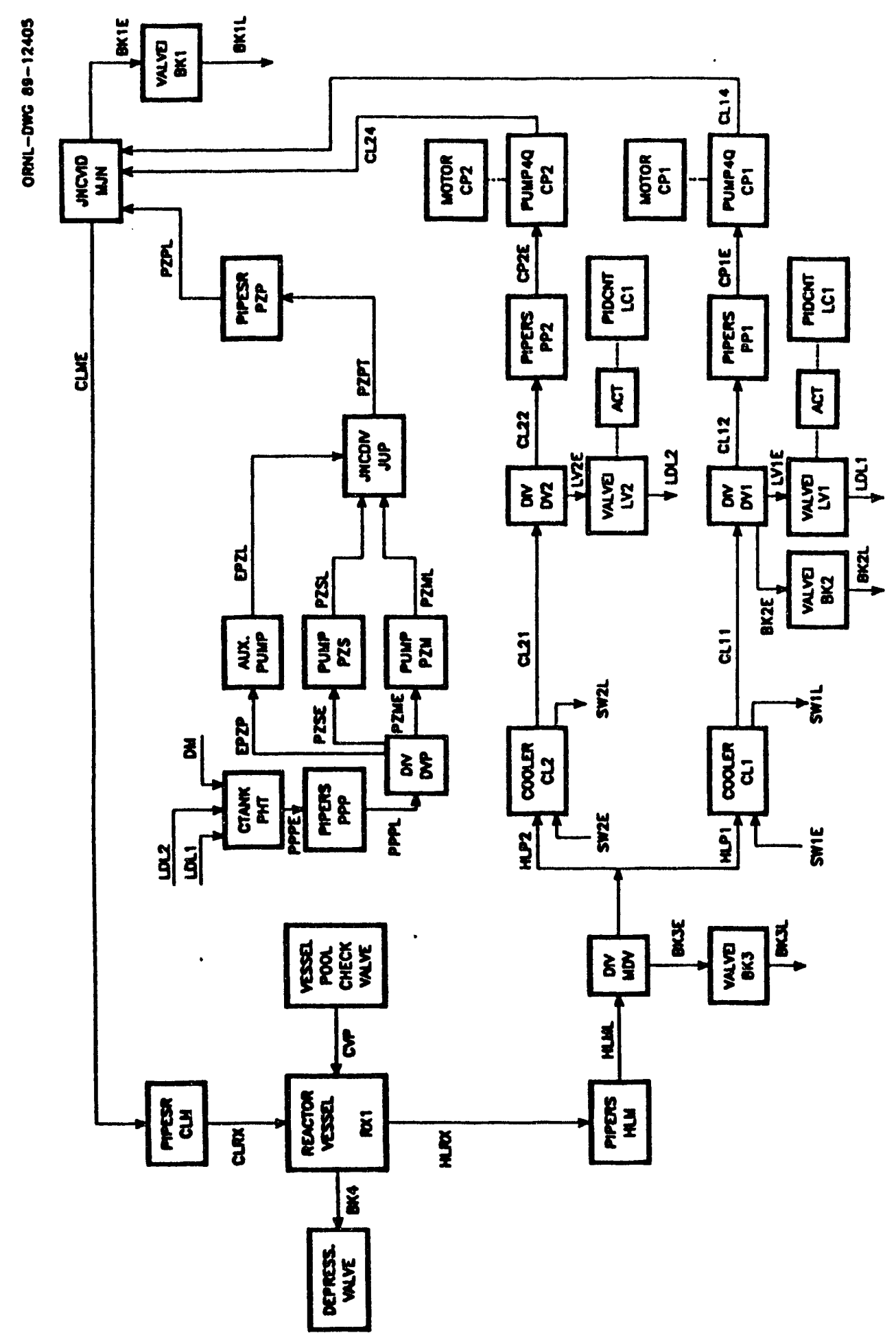

这 
valves is connected to the discharge of the main circulation pumps and the exit to the primary coolant storage tank. The losses associated with the upstream and downstream piping of the relief valves are represented by including their flow conductances in the relief valve module (i.e., effectively increasing the pressure drop through the valve).

The definition "flow conductance," a correlation constant between flow and friction and form loss pressure drop, is specific to MMS and similar to resistance in electric flow. The flow conductance term simply represents a combination of friction and form loss factors, average cross sectional area, and length to diameter ratio as indicated in Eq. (5). Its magnitude can either be calculated from Eq. (8) using known flow rates and pressure drops or from Eq. (5). The form losses and dimension data for the upstream and downstream piping were taken from the document prepared by $\left(\right.$ Lepard $^{18}$ ) for the RELAP5 simulations of the pressurizer pump overspeed transients. The total loss factors for the pipe sections from the cold leg to the valve and from the valve to the primary coolant storage tank are $k=11.9$ and $k=4.35$, respectively. A combined flow conductance $\left(K_{c p}=K C P S R V\right)$ for the upstream and downstream lines is calculated using Eq. (5). Equation (5) requires form loss factors (k's) being substituted in terms of $f L / D$ as shown in Eqs. (6) and (7). The choice of units in the equation are specific to the MMS computer code.

$$
\begin{gathered}
K_{c p}=A\left(\frac{1}{f} \frac{D}{L} 2 g_{c}\right)^{\frac{1}{2}} 3600144^{\frac{1}{2}} \frac{1 b_{m}}{h}\left(p s i \frac{1 b_{m}}{f^{3}}\right)^{-\frac{1}{2}} \\
k=f \frac{L}{D} \\
\text { f } \frac{L}{D}=4.35+11.9
\end{gathered}
$$

where $A=0.0884 \mathrm{ft}^{2}$ (internal flow cross sectional area of 4-in. line).

Substitution of the numerical values into $\mathrm{Eq}$. (5) provides a numerical value for the flow conductance of the relief valve piping.

$$
\mathrm{K}_{\mathrm{cp}}=\mathrm{KCPSRV}=7602.4 \mathrm{lb}_{\mathrm{m}} / \mathrm{h}\left(\mathrm{psi} \mathrm{lb}_{\mathrm{m}} / \mathrm{ft}^{3}\right)^{-1 / 2}
$$

The flow conductance of the lines named KCPSRV in HFIRSYS is input to the valve module; therefore, the pressure drop due to upstream and downstream piping is included although the lines are not modelled as separate component modules.

The flow conductance of the valves ( $\mathrm{K}_{c v}=\mathrm{KCVSRV}$ ) is calculated from Eq. (8) which uses known flow rate, pressure drop, valve characteristics, and valve position. 


$$
K_{\mathrm{ev}}=\frac{w}{\left(\rho \Delta \mathbf{P}_{\text {find }}\right)^{\frac{1}{2}} f(y)}
$$

where

$f(y)=a$ function of the valve position based on valve characteristics,

$w=$ flow rate through the valve $\left(\mathrm{lb}_{\mathrm{m}} / \mathrm{h}\right)$,

$\rho=$ density $\left(\mathrm{lb}_{\mathrm{m}} / \mathrm{ft}^{3}\right)$, and

$P_{\text {fric }}=$ pressure drop through the valve.

The $f(y)$ functions in the MMS computer code is defined by the following equations:

$f(y)=y^{3}$, equal percentage characteristics,

$f(y)=y$, linear characteristics, and

$f(y)=1-e^{-10 y}$, quick opening characteristics.

The variation of the percent flow as a function of percent valve opening for each valve characteristic is explained in a control valve handbook. ${ }^{19}$ The equal percentage characteristics are conservatively assumed for the relief valves. The relief valve flow conductance was calculated based on $296 \mathrm{gpm}$ valve capacity and 682 psi pressure drop through the valve at the full open position. Using water density equal to $62 \mathrm{lb}_{\mathrm{m}} / \mathrm{ft}^{3}$, the valve flow capacity in $\mathrm{lb}_{\mathrm{m}} / \mathrm{h}$ is

$$
\begin{aligned}
\text { valve capacity } & =296 \mathrm{gpm} 60 \mathrm{~min} / \mathrm{h} 0.1337 \mathrm{ft}^{3} / \mathrm{gal} 62 \mathrm{lb} / \mathrm{ft}^{3} \\
& =147,220 \mathrm{lb}_{\mathrm{m}} / \mathrm{h} .
\end{aligned}
$$

The flow conductance of one relief valve ( $\mathrm{K}_{\mathrm{cv}}=\mathrm{KCVSRV}$ ) input to the MMS VALVEI module based on the valve capacity, fully open valve position $(y=1)$, and water density of $62 \mathrm{lb}_{\mathrm{m}} / \mathrm{ft}^{3}$ is

$$
\begin{aligned}
& \mathrm{K}_{\mathrm{cv}}= \frac{147,220 \frac{\mathrm{lb}}{\mathrm{m}}}{\left(62 \frac{\mathrm{lb}}{\mathrm{ft}^{3}} 682 \mathrm{psi}\right)^{\frac{1}{2}}} \\
& \mathrm{~K}_{\mathrm{cv}}=\mathrm{KCVSRV}=715.94 \mathrm{lb}_{\mathrm{m}} / \mathrm{h}\left(\mathrm{psi} \mathrm{lb}_{\mathrm{m}} / \mathrm{ft}^{3}\right)^{-1 / 2}
\end{aligned}
$$

The main circulation pump discharge pressure at the cold leg is applied to the inlet of the relief valves. The HFIR relief valves were programmed to open in a prespecified time and at a set point pressure in the model. The opening time was set at $0.1 \mathrm{~s}$ and the closing time was instantaneous in all of the runaway pressurizer pump speed transients reported in the following Sect. 5. The $0.1 \mathrm{~s}$ opening time is the same as the value used in the RELAP5 simulations of the pressurizer pump overspeed transients. ${ }^{18}$ It is an assumption and is not 
based on any test data related to the HFIR relief valves. The equal percentage characteristics results in less flow compared to the flows through the valves with linear or quick opening characteristics when the valves are not in fully open position. Effects of the different valve characteristics on consequences of the transients are examined in Sect. 5.7.1. 


\section{HFIRSYS SIMULATIONS OF THE PRESSURIZER PUMP OVERSPEED TRANSIENTS}

\subsection{CONSTRAINTS IMPOSED ON PRESSURIZER PUMP OVERSPEED TRANSIENTS}

The pressurizer pump overspeed transients of the category of the increase in coolant inventory transients are among the many other transients that are to be analyzed for Chap. 15 of the HFIR safety analysis report. ${ }^{15}$ The constraints to be imposed on these transients in this category were defined in a report by (Radcliff, and Lepard) ${ }^{14}$ and repeated here for three different major groups. These constraints were imposed on the transient simulations described Sects. 5.2 through 5.7.

\section{Pressurizer Pump Overspeed Event:}

- Instantaneous lockup of the magnetic coupler (The pump speed increases to $3560 \mathrm{rpm}$ based on the motor, pump, and coupler inertia and the motor torque.)

- Initial power is not important since margin to boiling increases during this transient.

- Reactor power should not change significantly because subcooled water density changes very little with pressure.

- The primary coolant temperature should be set at $93.8^{\circ} \mathrm{F}$ to minimize compressibility of the coolant and structural elasticity.

- The initial pressure should be set at both the high alarm limit $(493+12)=505$ psig $(519.7$ psia) and the low alarm limit $(418-18)=406$ psig $(420.7$ psia) to ensure maximum pressure increase.

- The pressurizer pump trip will occur at the technical specification limit of 580 psig (594.7 psia).

- The relief valve and rupture disc combination will open at the technical specification limit of 689 psig (703.7 psia).

- Letdown valve positions are conservatively assumed not to change (p. 39).

- The pressure rise in the underground primary coolant storage tank and losses in the piping to the tank should be considered.

\section{Pressurizer Pump Overspeed and Relief Valves Remain Closed:}

- The initial conditions and other constraints are the same as those of the pressurizer pump overspeed except for failure of relief valves to open. The pressurizer pump trips are available.

\section{Pressurizer Pump Overspeed and Failure of the Pressurizer Pump Trip:}

- The initial conditions and other constraints are the same as those of the pressurizer pump overspeed except for failure of pressurizer pump trip.

The naming convention used for the RELAP5 simulations of the pressurizer pump overspeed transients is used for the HFIRSYS simulations of the same transients. The 
pressurizer pump overspeed transients are also referred to as "runaway pressurizer pump speed transients" in this and other documents. They may be also referred to as "overpressurization transients" since the primary coolant system is pressurized by increased pressurizer pump flow.

In the transients analyzed in this section, the pressurizer pump speed was increased by instantaneously inereasing the torque to the value necessary for producing $3560 \mathrm{rpm}$. Because of friction and the inertia of the rotating parts, the pump speed increase is not instantaneous. The block valves in the letdown lines are allowed to close in $4 \mathrm{~s}$ conservatively. This may cause the primary system pressure to fall below the reactor trip set point after the pressurizer pump is tripped. If they instantaneously close at their set point, the reactor trip will be delayed until the primary coolant system pressure decreases to the reactor trip set point due to water loss from the system. Since the primary coolant system is water solid, small amount of water loss causes large changes in the pressure.

All of the figures related to the transient results are numbered after their alphanumeric case names so that the figures and the cases can easily be related to each other. For example: If the case name is $1 \mathrm{a} 1$, then the figures are numbered as $1 \mathrm{a1.1}, 1 \mathrm{a1} .2, \ldots . .$, and 1a1.6.

\subsection{THE PRESSURIZER PUMP OVERSPEED WITH ALL MITIGATING EQUIPMENT OPERATIONAL (CASE 1A1)}

The reactor vessel inlet plenum pressure is 420.7 psia initially in this transient. The reactor power was $85 \mathrm{MW}$. The secondary side inlet temperature was reduced to keep the primary coolant inlet temperature at about $93.8^{\circ} \mathrm{F}$. Both of the pressurizer pump trips operate. The maximum torque was applied to the pump at $10 \mathrm{~s}$ to accelerate the pump speed to $3560 \mathrm{rpm}$ while the reactor was operating under nominal conditions. The pressurizer pump was tripped at high discharge pressure when the pump speed was about $2939 \mathrm{rpm}$ (Fig. 1a1.1). After the pump trip, the pressure continued to fall.

The calculation was continued up to about $30 \mathrm{~s}$. The letdown valve positions do not change as required by the constraints imposed on the transient. The block valves were also required to close conservatively in $4 \mathrm{~s}$ after the primary system pressure fell below the block valve closure set point. Due to the 4-s closure time, the reactor inlet pressure fell below the reactor trip set point, causing the reactor and secondary side to trip (Fig. 1a1.2). The reactor outlet pressure is also shown in the figure. The auxiliary pressurizer pump came on due to low pressurizer pump discharge flow (Fig. 1a1.3). The letdown flow rate became zero after the block valves were closed as indicated in the figure. Note that if the block valves were assumed to close instantaneously, they would have closed at 407.7 psia. This might have resulted in no reactor trip until the primary pressure falls below the trip set point due to leakage. The maximum values of some of the system variables are listed in Table 8. 


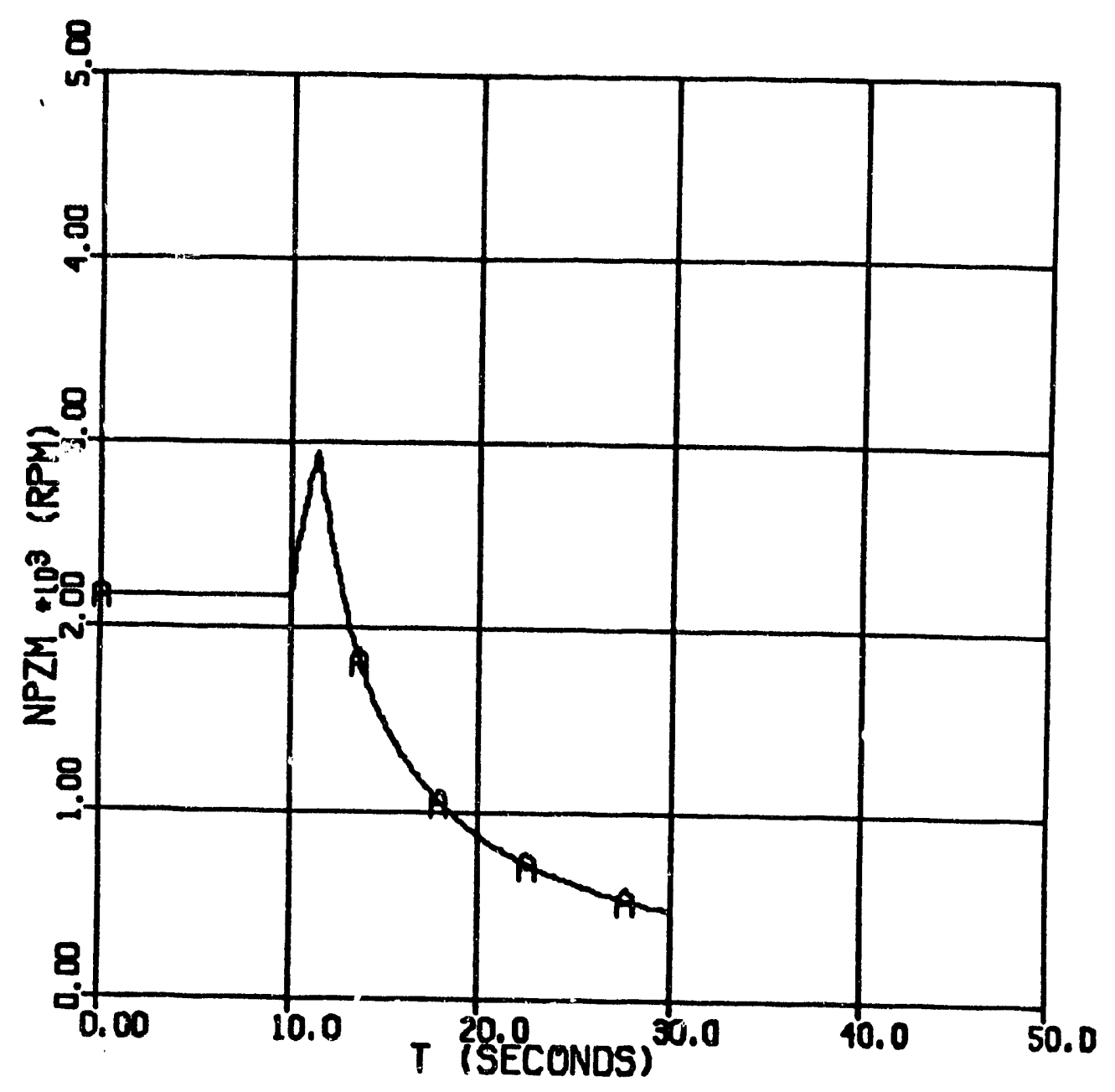
case 1a1.

Fig. 1a1.1. The pressurizer pump speed for pressurizer pump overspeed transient

$$
\begin{aligned}
& \text { NPZM }=\text { pressurizer pump speed (rpm) - curve A } \\
& T \quad=\text { time (s) }
\end{aligned}
$$




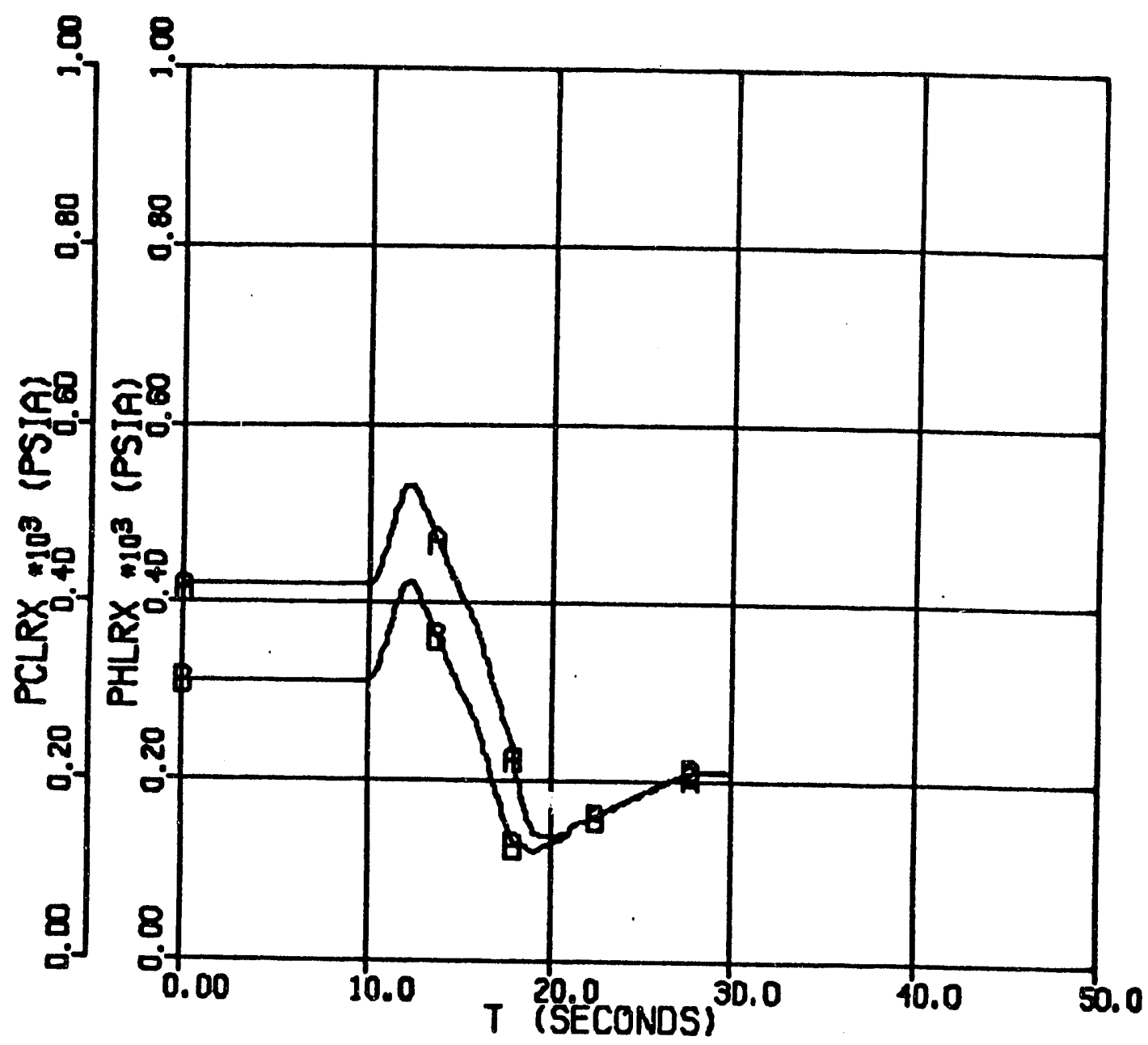

Fig. 1a12 The reactor inlet and outlet pressures for pressurizer pump overspeed transient case $1 \mathrm{a} 1$.

$$
\begin{aligned}
& \text { PCLRX = inlet plenum pressure (psia) - curve A } \\
& \text { PHIRX = outlet plenum pressure (psia) - curve B } \\
& T \quad=\text { time (s) }
\end{aligned}
$$




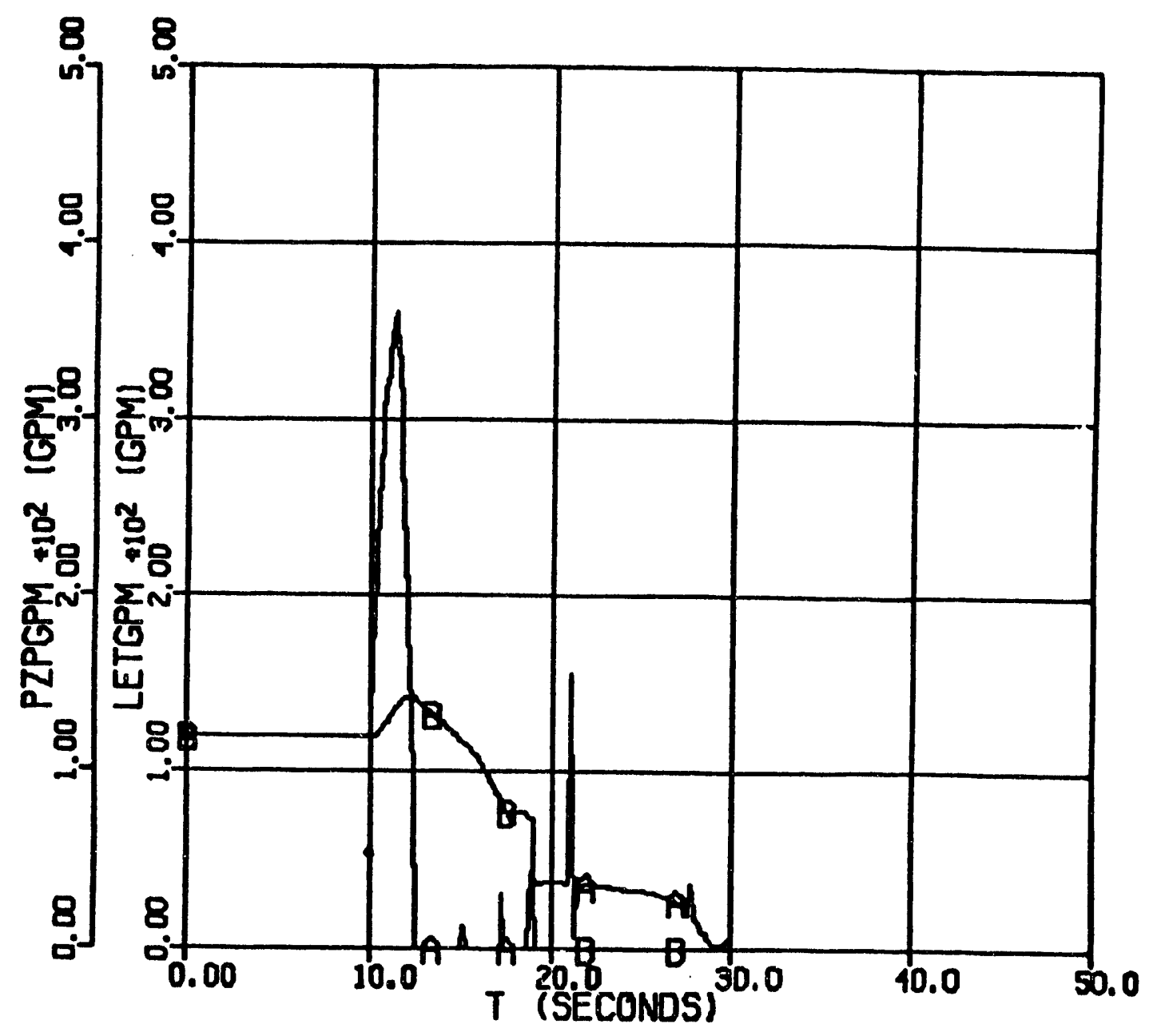

Fig. 1a1.3. The pressurizer pump and letdown flow rates for pressurizer pump overspeed transient case 1a1.

$$
\begin{array}{lll}
\text { PZPGPM } & =\text { pressurizer pump flow (gpm) } & \text { - curve A } \\
\text { LETGPM } & =\text { letdown flow (gpm) } & \text { - curve B } \\
\text { T } & =\text { time (s) } &
\end{array}
$$


Table 8. The maximum values of the several system variables for case $1 \mathrm{a} 1$

\begin{tabular}{lc}
\hline \multicolumn{1}{c}{ Variable } & $\begin{array}{c}\text { Maximum } \\
\text { value }\end{array}$ \\
\hline Relief valve flow, gpm & 0.00 \\
Pressurizer pump discharge pressure, psia & 605 \\
Inlet plenum pressure, psia & 532 \\
Main circulation pump discharge pressure, psia & 552 \\
Pressurizer pump speed, rpm & 2939 \\
\hline
\end{tabular}

The maximum reactor inlet plenum pressure was 532.3 psia and the maximum pressure point in the system was at the discharge of the pressurizer pump equal to 605 psia. The rupture disks and relief valves were not challenged in this transient. The letdown valve positions remained unchanged (requirement as part of the transient description). The auxiliary pressurizer pump came on after the pressurizer pump was tripped and the pressurizer pump flow was as low as $75 \mathrm{gpm}$. The auxiliary pump was able to keep the primary coolant system pressure at about 200 psia.

\subsection{PRESSURIZER PUMP OVERSPEED WITH ALL MITIGATING EQUIPMENT OPERATIONAL (CASE 1B1)}

The initial reactor inlet pressure is about 519.7 psia in this transient. This transient is not simulated as it was not simulated using RELAP5/MOD2.5 because the pressurizer pump trips early in the transient without any challenge to the relief valves.

\subsection{PRESSURIZER PUMP OVERSPEED WITH FAILURE OF THE HIGH DISCHARGE PRESSURE TRIP (CASE 3A1)}

The reactor inlet pressure is 420.7 psia initially in this transient. The reactor operates at about $85 \mathrm{MW}$ power. The secondary side inlet temperature was reduced to keep the primary inlet temperature around $93.8^{\circ} \mathrm{F}$. The pressurizer pump low suction pressure trip is available in this case. The high discharge pressure trip is disabled. At $10 \mathrm{~s}$ during the nominal operation, suddenly the maximum torque was applied to the pressurizer pump to accelerate the pump to the $3560 \mathrm{rpm}$. As the flow rate through the pump was increased, its suction pressure dropped below the trip set point. In $5 \mathrm{~s}$ after the suction pressure fell below the trip set point (15.2 psia), the pump was tripped at low suction pressure. The maximum pressurizer pump speed was $3502 \mathrm{rpm}$ (Fig. 3a1.1) and the reactor inlet pressure rose as high as 710 psia (Fig. 3a1.2). The reactor outlet pressure is also shown in the figure. The relief valve (only one flow path open) opened to decrease the primary coolant system pressure (Fig. 3a1.3). The letdown valve positions do not change as required by the constraints imposed on the transient. The block valves were also required to close in $4 \mathrm{~s}$ conservatively 


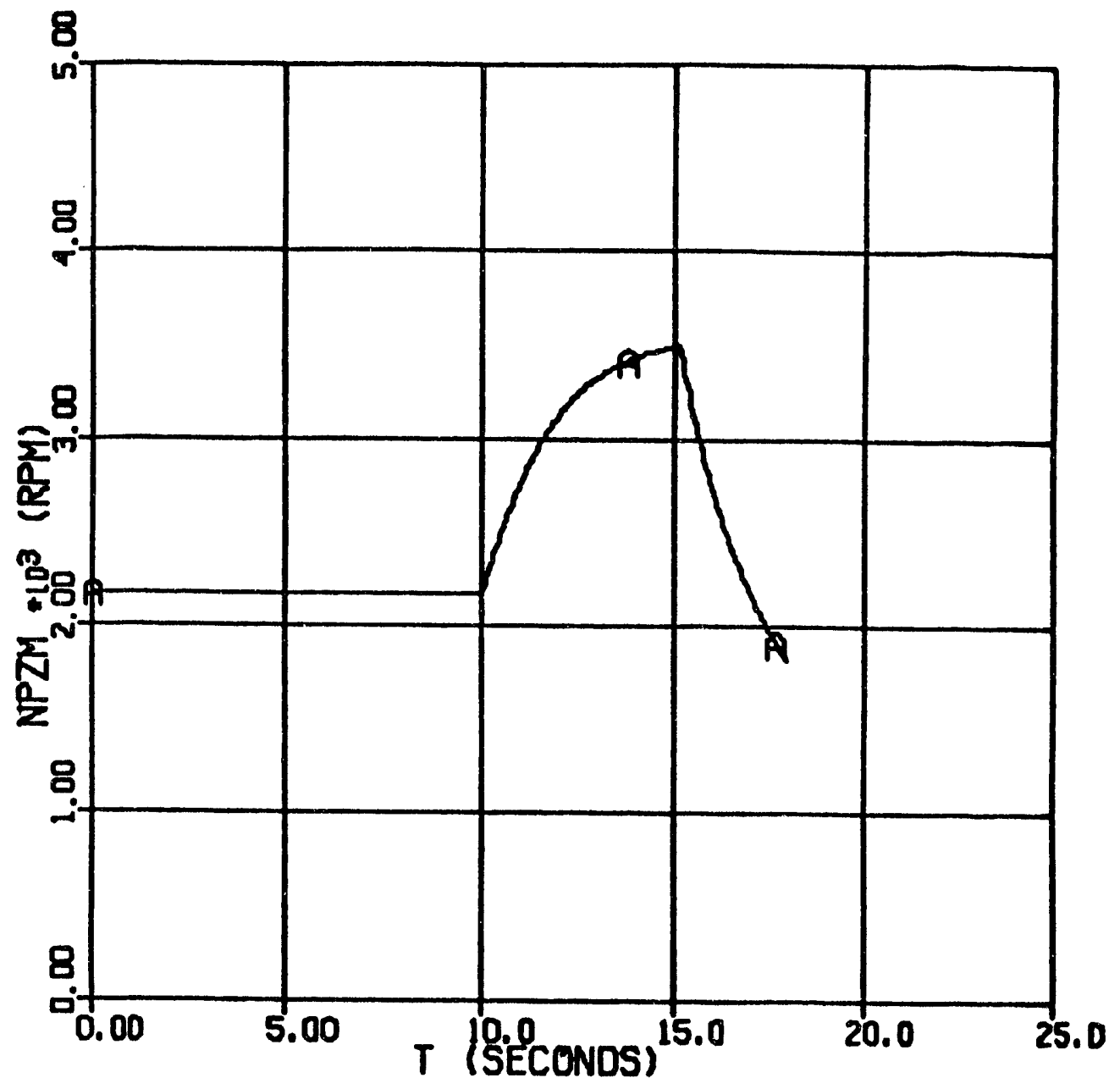
case $3 a 1$.

Fig. 3a1.1. The pressurizer pump speed for pressurizer pump overspeed transient

$$
\begin{aligned}
\text { NPZM } & =\text { pressurizer pump speed }(\mathbf{r p m}) \quad \text { - curve } A \\
\mathbf{T} & =\text { time }(s)
\end{aligned}
$$




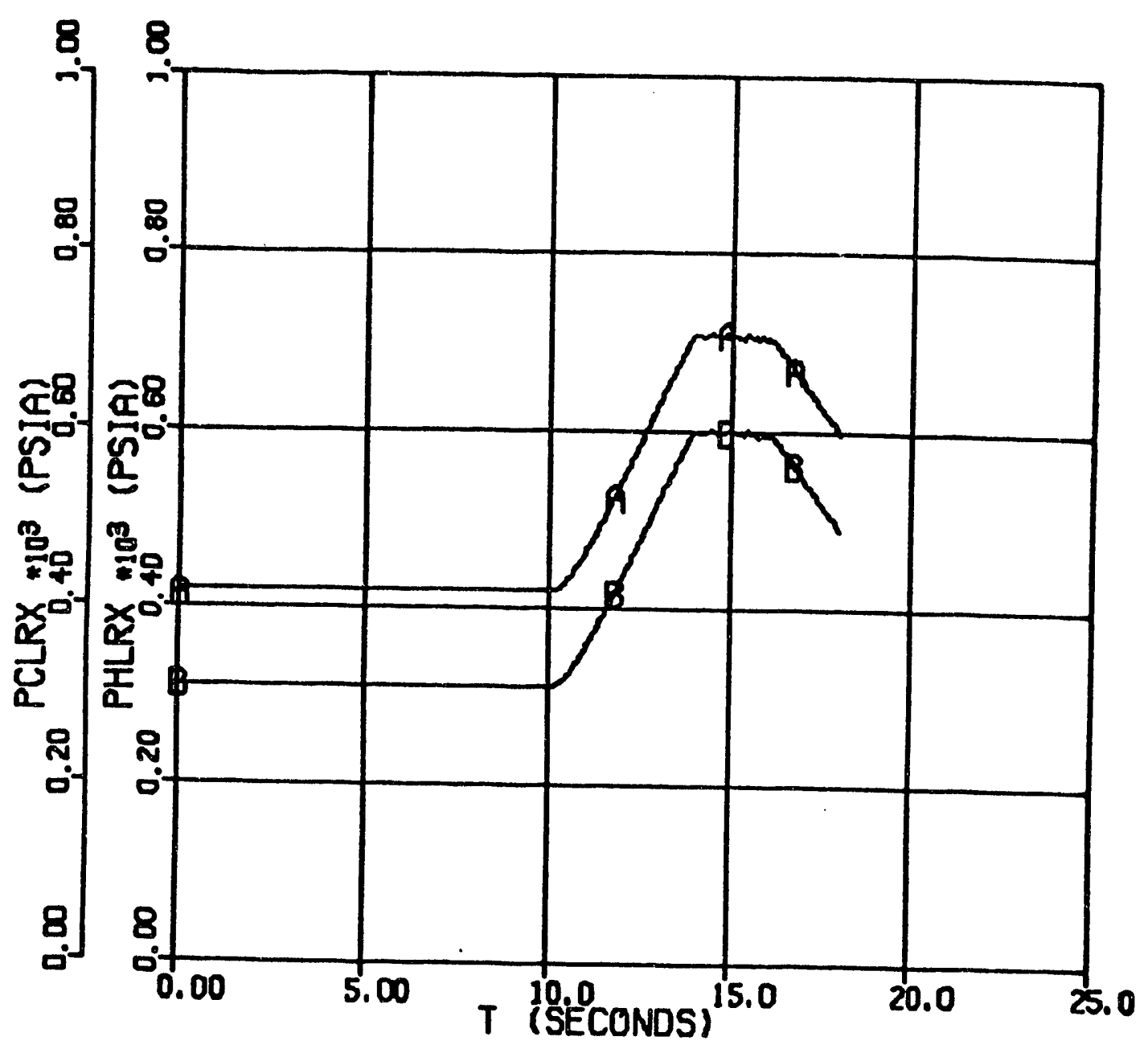

Fig. 3a1.2 The reactor inlet and outlet pressures for pressurizer pump overspeed transient case $3 \mathrm{a}$.

$$
\begin{array}{lll}
\text { PCLRX } & =\text { inlet plenum pressure (psia) } & \text { - curve A } \\
\text { PHLRX } & =\text { outlet plenum pressure (psia) } & \text { - curve B } \\
\text { T } & =\text { time (s) }
\end{array}
$$




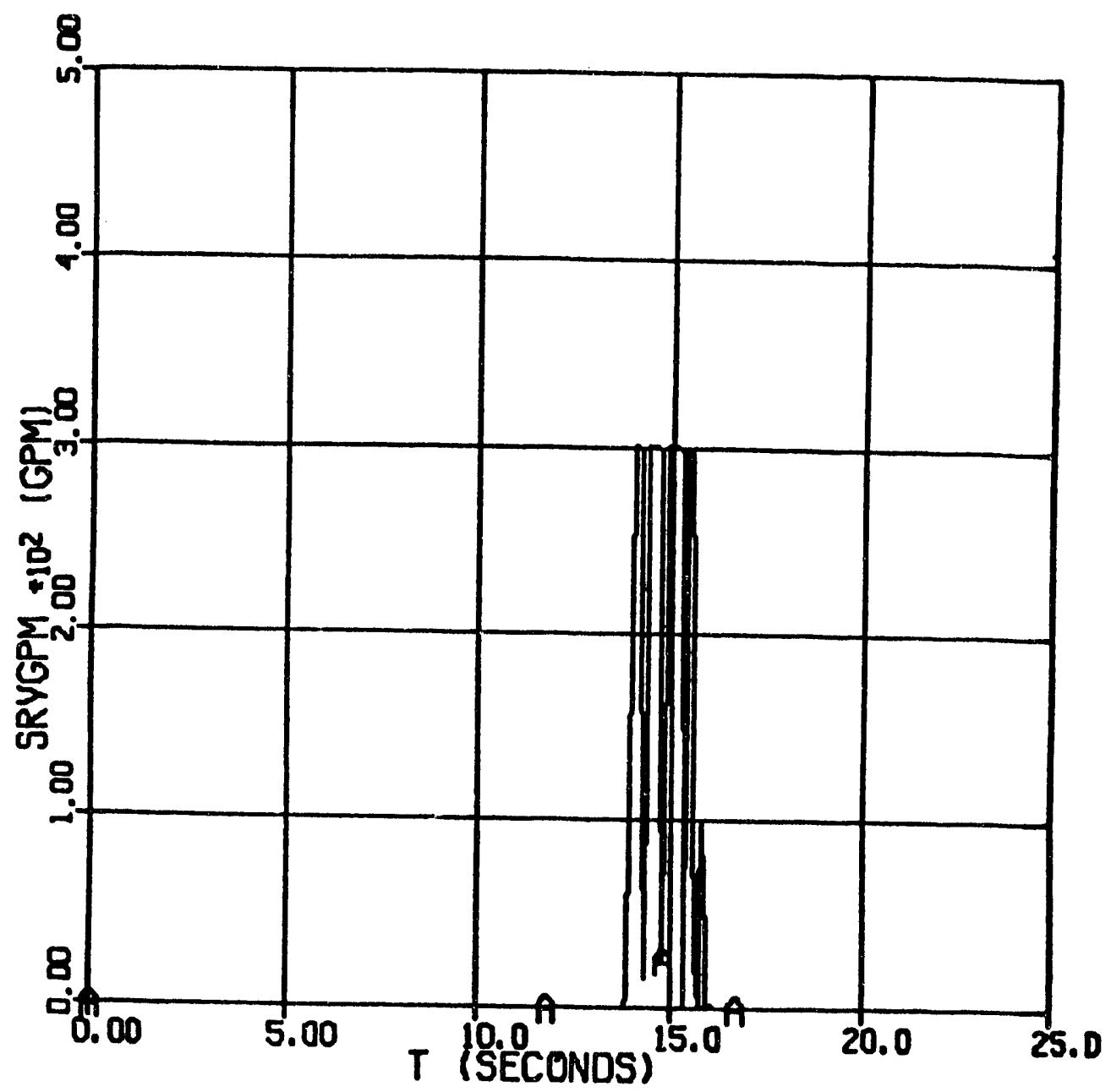

Fig. 3a1.3. The relief valve flow rate for pressurizer pump overspeed transient case $3 \mathrm{a} 1$.

$$
\begin{array}{ll}
\text { SRVGPM } & =\text { relief valve flow }(\text { gpm }) \quad \text { - curve A } \\
T & =\text { time }(s)
\end{array}
$$


after the primary system pressure falls below the block valve closure set point. About $3 \mathrm{~s}$ after the pressurizer pump was tripped, the calculation was stopped at about $18 \mathrm{~s}$ deliberately. Crucial point in all of these transients is to estimate how high the primary coolant pressure may rise; therefore, shortly after the pressurizer pump trip the calculation was stopped. If the calculation were continued, the primary coolant system pressure would have fallen below the reactor trip set point causing the reactor and secondary side to trip.

The pressurizer pump flow and letdown flow rates are shown in Fig. 3a1.4 up to $18 \mathrm{~s}$. Note that if the block valves were assumed to close instantaneously, they would have closed at 407.7 psia. This would have delayed the reactor trip until the primary coolant system pressure was decreased below the reactor trip set point pressure due to leakage from the primary coolant system. The maximum values of some of the system variables are listed in Table 9.

Table 9. The maximum values of the several system variables for case $3 a 1$

\begin{tabular}{lc}
\hline \multicolumn{1}{c}{ Variable } & $\begin{array}{c}\text { Maximum } \\
\text { value }\end{array}$ \\
\hline Relief valve flow, gpm & 302 \\
Pressurizer pump discharge pressure, psia & 835 \\
Inlet plenum pressure, psia & 710 \\
Main circulation pump discharge pressure, psia & 734 \\
Letdown flow, gpm & 172 \\
Pressurizer pump flow, gpm & 433 \\
\hline
\end{tabular}

\subsection{PRESSURIZER PUMP OVERSPEED WITH FAILURE OF THE HIGH DISCHARGE PRESSURE TRIP (CASE 3B1)}

The reactor inlet pressure is about 519.7 psia initially in this transient. The reactor operates at about $85 \mathrm{MW}$ power. The secondary side inlet temperature was reduced to keep the primary inlet temperature around $93.8^{\circ} \mathrm{F}$. The pressurizer pump low suction trip is available in this case. The high discharge pressure trip is disabled. At $10 \mathrm{~s}$ into the operation, suddenly the maximum torque was applied to the pressurizer pump to accelerate the pump to the $3560 \mathrm{rpm}$. As the flow rate through the pump was increased, its suction pressure dropped below the trip set point (Fig. 3b1.1). In $5 \mathrm{~s}$ the pump was tripped at low suction pressure.

The maximum pressurizer pump speed was $3513 \mathrm{rpm}$ and the reactor inlet pressure rose as high as 712 psia (Fig. 3b1.2). The reactor outlet pressure is also shown in the figure. The relief valve (only one flow path open) opened to decrease the primary coolant system pressure (Fig. 3b1.3). 


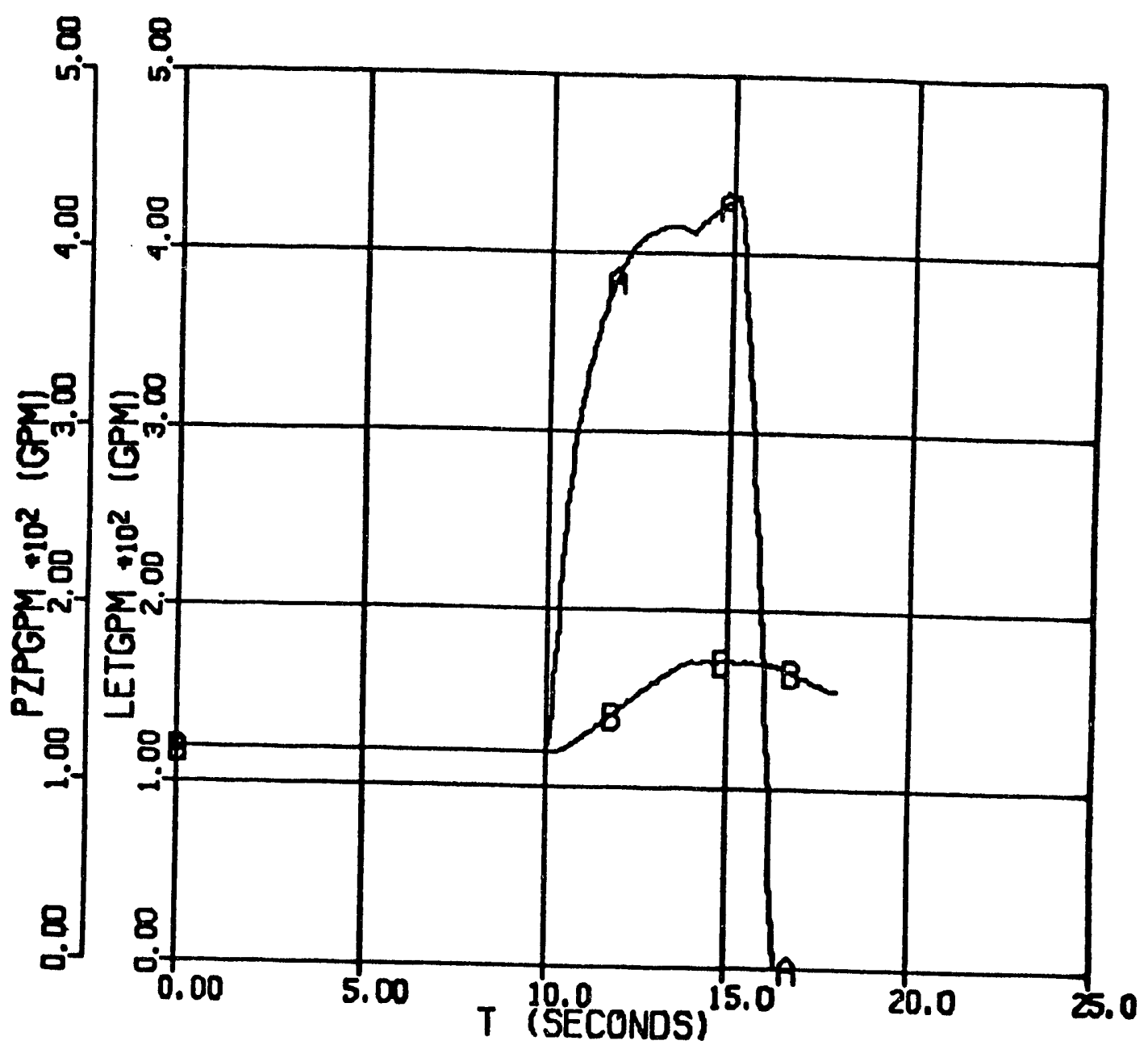

Fig. 3a1.4. The pressurizer pump and letdown flow rates for pressurizer pump overspeed transient case 3 a1.

$$
\begin{array}{lll}
\text { PZPGPM } & =\text { pressurizer pump flow (gpm) } & \text { - curve A } \\
\text { LETGPM } & =\text { letdown flow (gpm) } & \text { - curve B } \\
\text { T } & =\text { time (s) } &
\end{array}
$$




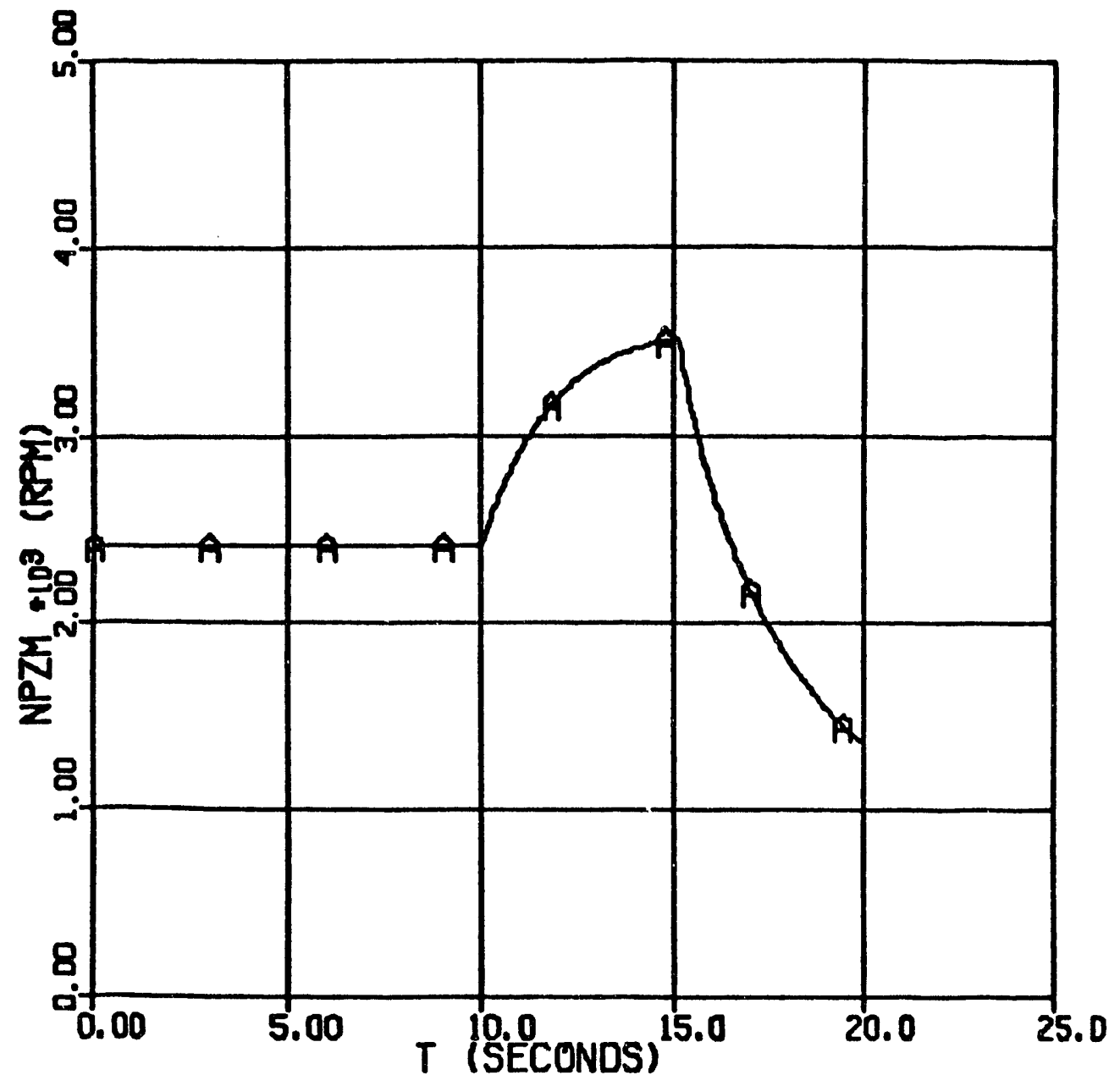

Fig. 3b1.1. The pressurizer pump speed for pressurizer pump overspeed transient case $3 b 1$.

$$
\begin{aligned}
& \text { NPZM }=\text { pressurizer pump speed (rpm) - curve } A \\
& T \quad=\text { time }(s)
\end{aligned}
$$




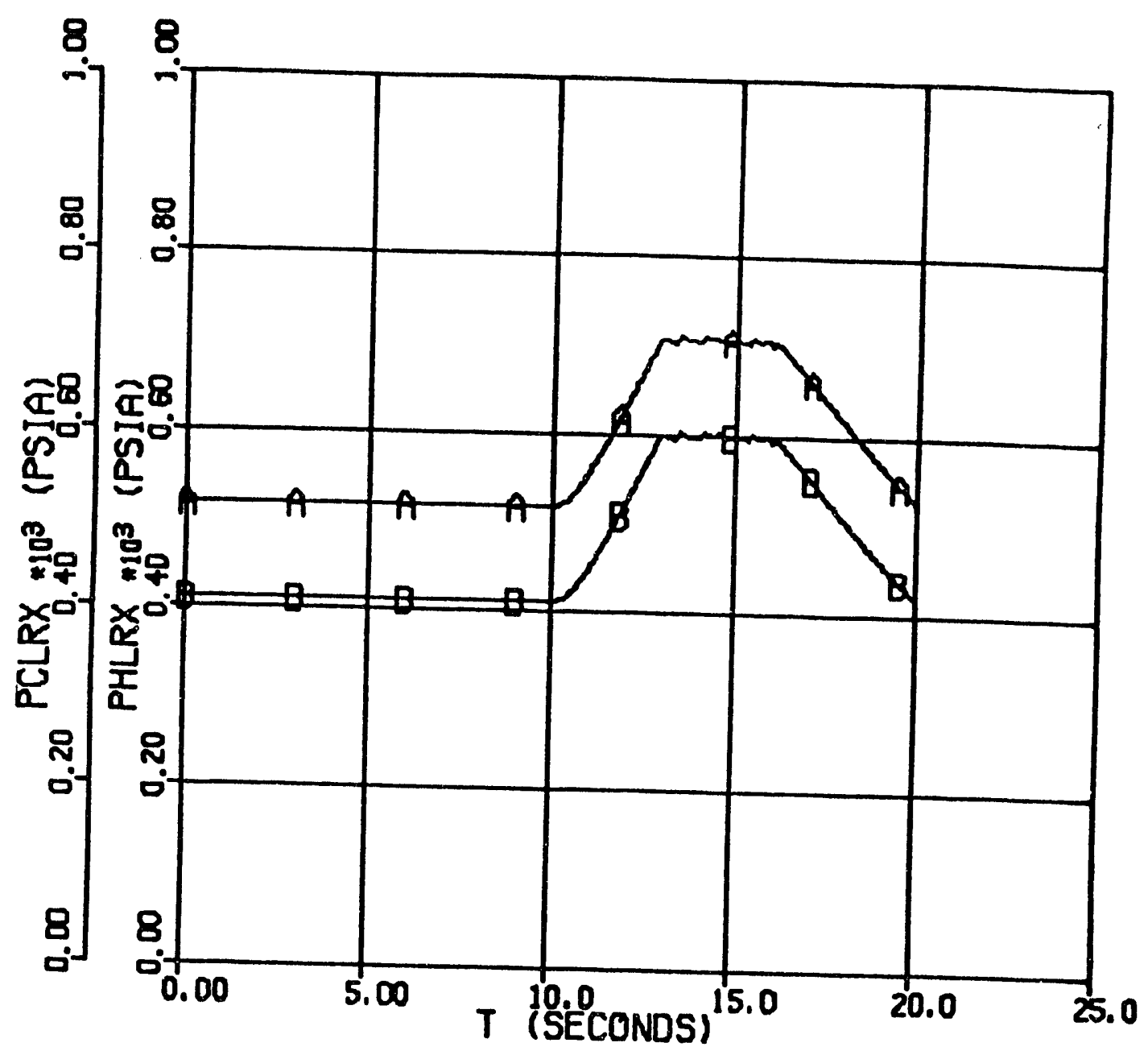

Fig. 3b1.2. The reactor inlet and outlet pressures for pressurizer pump overspeed transient case $3 b 1$.

$$
\begin{aligned}
& \text { PCLRX = inlet plenum pressure (psia) - curve A } \\
& \text { PHLRX = outlet plenum pressure (psia) - curve B } \\
& T=\text { time (s) }
\end{aligned}
$$




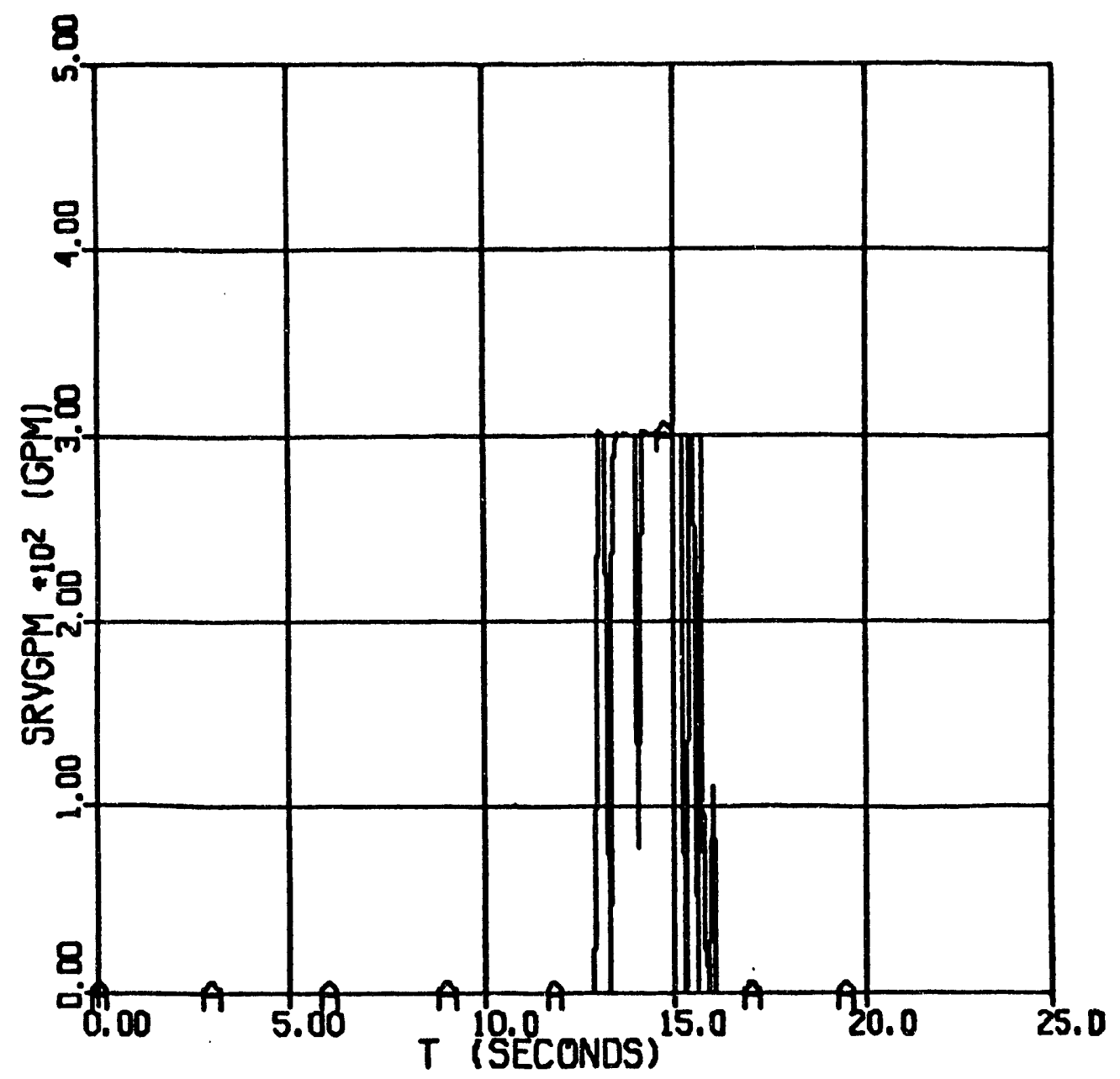

Fig. 3b1.3. The relief valve flow rate for pressurizer pump overspeed transient case $3 b 1$.

$$
\begin{aligned}
\text { SRVGPM } & =\text { relief valve flow }(\mathrm{gpm}) \quad \text { - curve } A \\
\mathrm{~T} & =\text { time }(\mathrm{s})
\end{aligned}
$$


This is a built-in assumption - only one relief valve available. The letdown valve positions do not change as required by the constraints imposed on the transient. The relief valve closed after the primary coolant system pressure fell below the set point pressure of the relief valves. The calculation was stopped at $20 \mathrm{~s}$ deliberately. If the calculation were continued, the primary coolant system pressure would have fallen below the reactor trip set point causing the reactor and secondary side to trip. The block valves were also required to close conservatively in $4 \mathrm{~s}$ after the primary system pressure falls below the block valve closure set point. The pressurizer pump and letdown flow rates are shown in Fig. 3b1.4. Note that if the block valves were assumed to close instantaneously, they would have closed at 407.7 psia. The reactor trip would have been delayed until the primary coolant system pressure falls below the reactor trip set point due to leakage. The maximum values of some of the variables are listed in Table 10.

Table 10. The maximum values of the several system variables for case $\mathbf{3 b 1}$

\begin{tabular}{lc}
\hline \multicolumn{1}{c}{ Variable } & $\begin{array}{c}\text { Maximum } \\
\text { valve }\end{array}$ \\
\hline Relief valve flow, gpm & 302 \\
Pressurizer pump discharge pressure, psia & 835 \\
Inlet plenum pressure, psia & 710 \\
Main circulation pump discharge pressure, psia & 734 \\
Letdown flow, gpm & 172 \\
Pressurizer pump flow, gpm & 433 \\
\hline
\end{tabular}

\subsection{PRESSURIZER PUMP OVERSPEED WITH FAILURE OF THE HIGH DISCHARGE AND LOW SUCTION PRESSURE TRIPS (CASE 3A2)}

The reactor inlet pressure is about 420.7 psia initially in this transient. The reactor operates at about $85 \mathrm{MW}$ power. The secondary side inlet temperature was reduced to keep the primary inlet temperature around $93.8^{\circ} \mathrm{F}$. The pressurizer pump low suction pressure trip is not available in this case. The high discharge pressure trip is also disabled. At $10 \mathrm{~s}$ into the operation, suddenly the maximum torque was applied to the pressurizer pump to accelerate the pump to the $3560 \mathrm{rpm}$. As the flow rate through the pump was increased, its suction pressure dropped below the trip set point. However, the pump was allowed to continue operating (Fig. 3a2.1). The maximum pressurizer pump speed was $3560 \mathrm{rpm}$ and the reactor inlet pressure rose as high as 712 psia (Fig. 3a2.2). The reactor outlet pressure is also shown in the figure.

One relief valve opened to decrease the primary coolant system pressure (Fig. 3a2.3). This is a built-in assumption about availability of the relief valves. The letdown valve positions do not change as required by the constraints imposed on the transient. The 


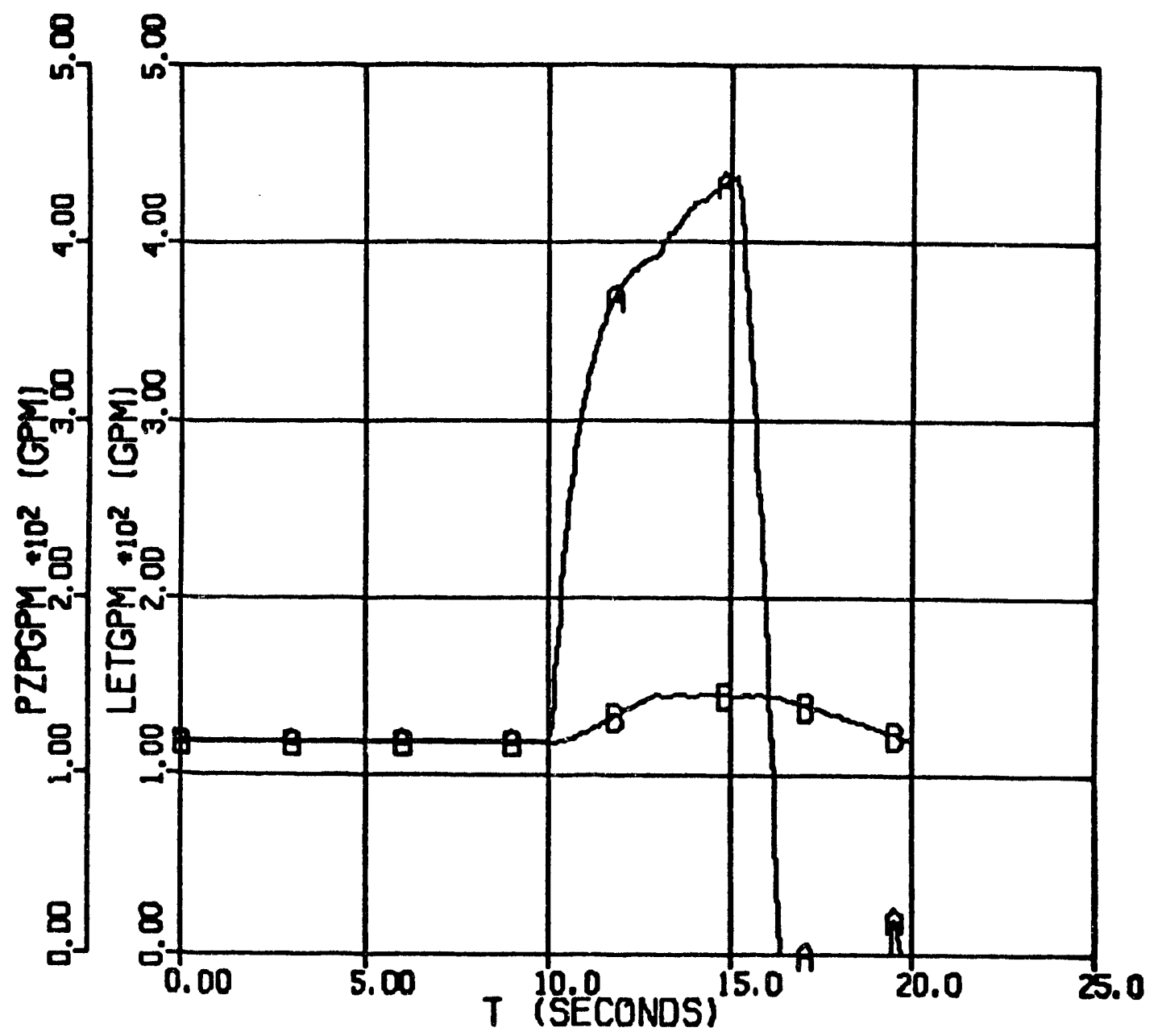

Fig. 3b1.4. The pressurizer pump and letdown flow rates for pressurizer pump overspeed transient case $3 \mathrm{~b} 1$.

$$
\begin{array}{lll}
\text { PZPGPM } & =\text { pressurizer pump flow (gpm) } & \text { - curve A } \\
\text { LETGPM } & =\text { letdown flow (gpm) } & \text { - curve B } \\
\text { T } & =\text { time }(\mathbf{s}) &
\end{array}
$$




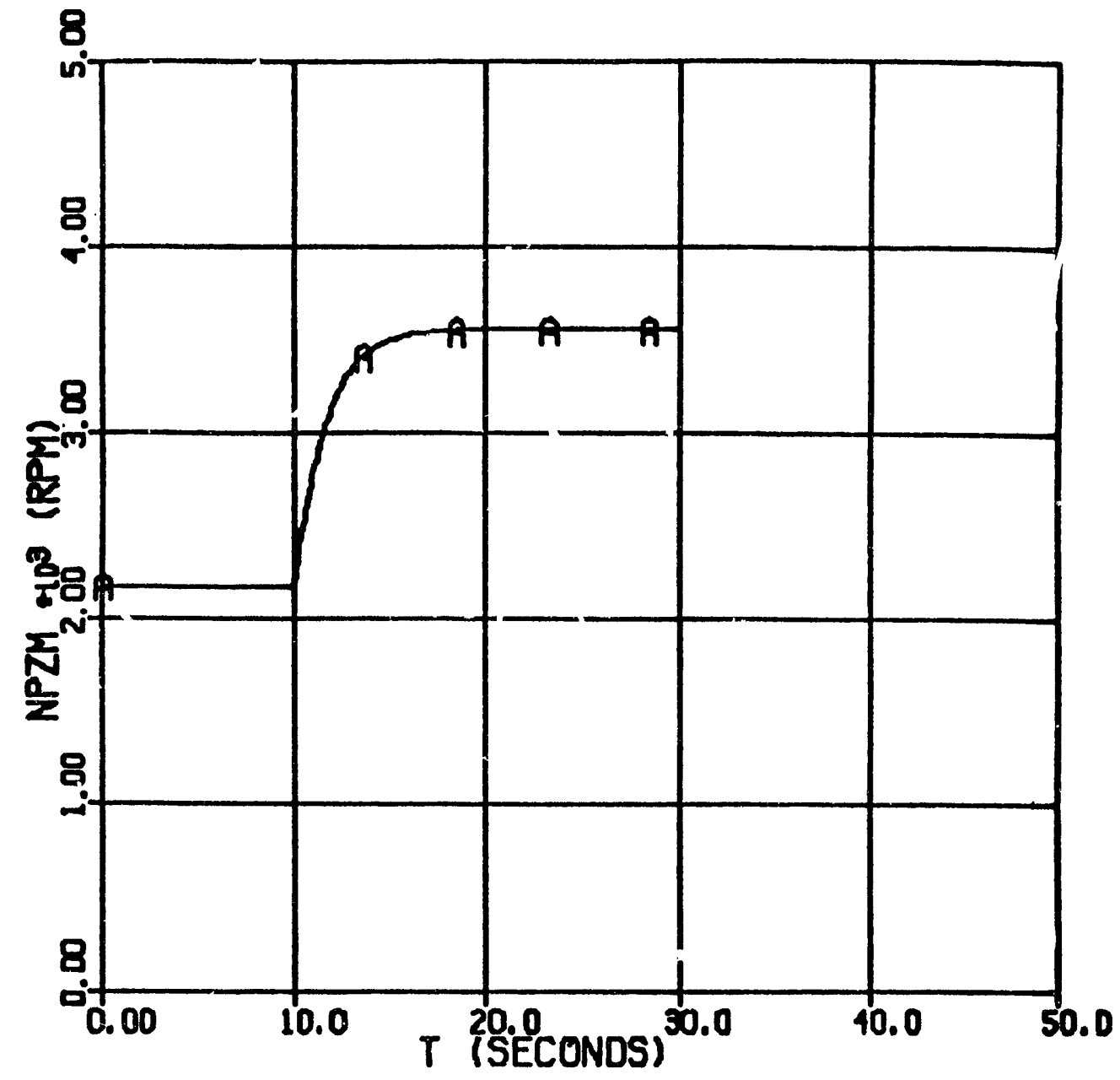

Fig. 3a21. The pressurizer pump speed for pressurizer pump overspeed transient case 322

$$
\begin{aligned}
& \text { NPZM }=\text { pressurizer pump speed (rpin) } \quad \text { - curve } A \\
& \mathbf{T}=\text { time (s) }
\end{aligned}
$$




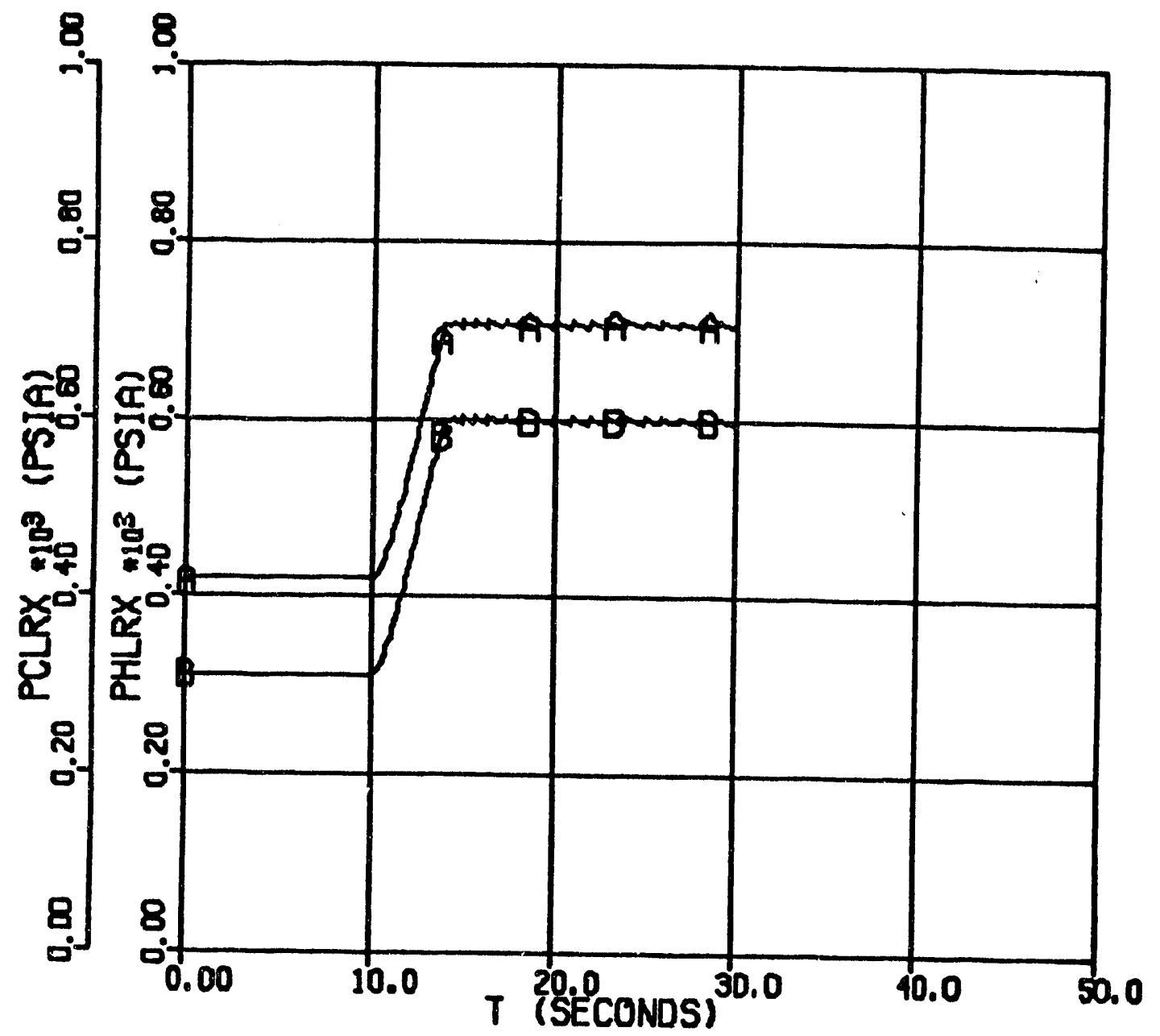

Fig. 3a22 The reactor inlet and outlet pressures for pressurizer pump overspeed transient case 302

$$
\begin{aligned}
& \text { PCLRX }=\text { inlet plenum pressure (psia) } \\
& \text { PHLRX }=\text { outlet plenum pressure (psia) } \\
& T \quad \text { - curve A } \\
& \text { - time (s) }
\end{aligned}
$$




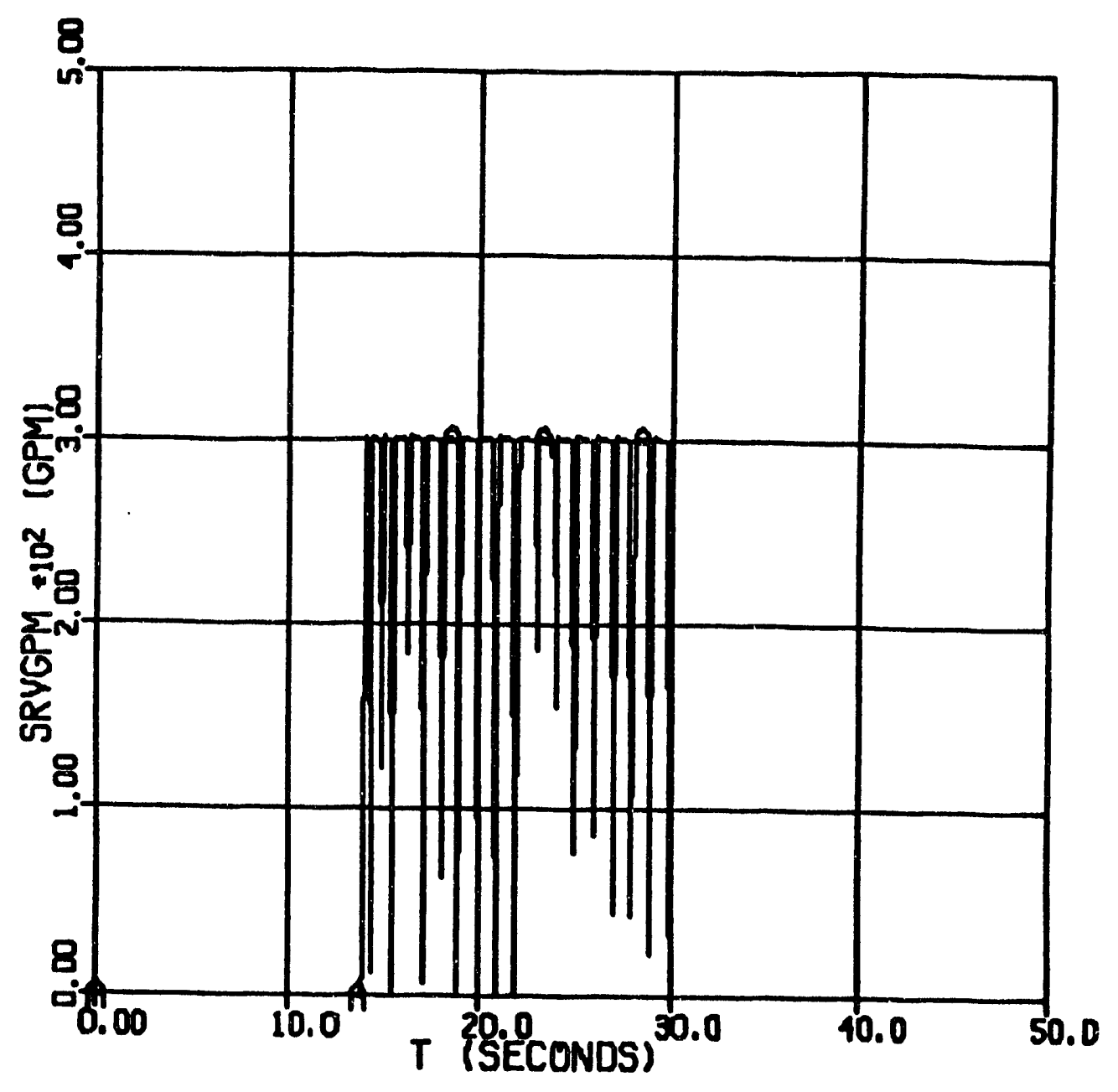

Fig. 3a23. The relief valve flow rate for pressurizer pump overspeed transient case $3 a_{2}$

$$
\begin{aligned}
& \text { SRVGPM }=\text { relief valve flow (spm) - curve A } \\
& \mathbf{T}=\text { time (s) }
\end{aligned}
$$


pressurizer pump and letdown flow rates are shown in Fig. 3a2.4. The block valves were also required to close conservatively in $4 \mathrm{~s}$ after the primary system pressure fell below the block valve closure set point. Due to disabled pressurizer pump trips, the primary coolant system pressure stayed high and the relief valve remained open in this transient. The calculation was stopped at about $30 \mathrm{~s}$. If the calculation were continued, the pressurizer pump would have tripped at low primary coolant head tank capacity $(<25 \%)$. Due to $4 \mathrm{~s}$ delay in the block valve closure time, the pressure would fall below reactor trip set point, causing the reactor and secondary side to trip. The auxiliary pressurizer pump would come on due to low pressurizer pump discharge flow. Note that if the block valves were assumed to close instantaneously, they would have closed at $\mathbf{4 0 7 . 7}$ psia. This might have resulted in no reactor trip until the primary pressure falls below the trip set point due to leakage. The maximum values of some of the system variables are listed in Table 11.

Table 11. The maximum values of the several system variables for case $3 a 2$

\begin{tabular}{lc}
\hline \multicolumn{1}{c}{ Variable } & $\begin{array}{c}\text { Maximum } \\
\text { valve }\end{array}$ \\
\hline Relief valve flow, gpm & 302 \\
Pressurizer pump discharge pressure, psia & 844 \\
Inlet plenum pressure, psia & 712 \\
Main circulation pump discharge pressure, psia & 734 \\
Letdown flow, gpm & 172 \\
Pressurizer pump flow, gpm & 452 \\
\hline
\end{tabular}

The primary coolant system remains pressurized near 700 psia in this transient. The pressurizer pump will eventually trip on low primary coolant head tank capacity if no operator action is taken.

\subsection{PRESSURIZER PUMP OVERSPEED WITH FAILURE OF THE HIGH DISCHARGE AND LOW SUCTION PRESSURE TRIPS (CASE 3B2)}

The reactor inlet pressure is about 519.7 psia initially in this transient. This is the only difference between this case and 3a2. The reactor operates at about $85 \mathrm{MW}$ power. The secondary side inlet temperature was reduced to keep the primary inlet temperature around $93.8^{\circ} \mathrm{F}$. The pressurizer pump low suction pressure trip is not available in this case. The high discharge pressure trip is also disabled. At $10 \mathrm{~s}$ into the operation, suddenly the maximum torque was applied to the pressurizer pump to accelerate the pump to the $3560 \mathrm{rpm}$. As the flow rate through the pump was increased, its suction pressure dropped below the trip set point. However, the pump was allowed to continue operating (Fig. 3b2.1). 


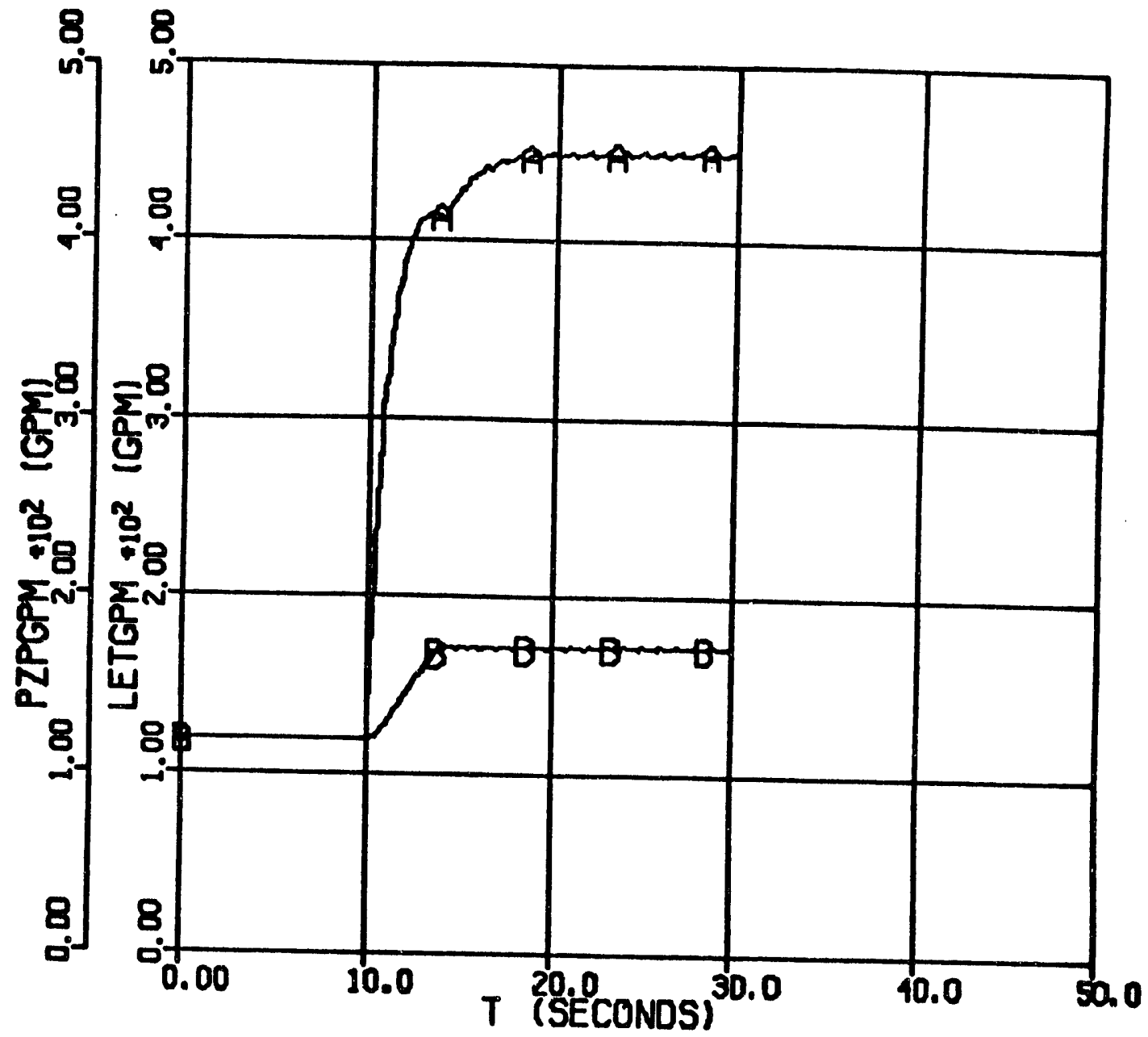

Fig. 3a24. The pressurizer pump and letdown flow rates for pressurizer pump overspeed transient case $3 a 2$.

$$
\begin{array}{lll}
\text { PZPGPM } & =\text { pressurizer pump flow (gpm) } & \text { - curve A } \\
\text { LETGPM } & =\text { letdown flow (gpm) } & \text { - curve B } \\
\text { T } & =\text { time (8) }
\end{array}
$$




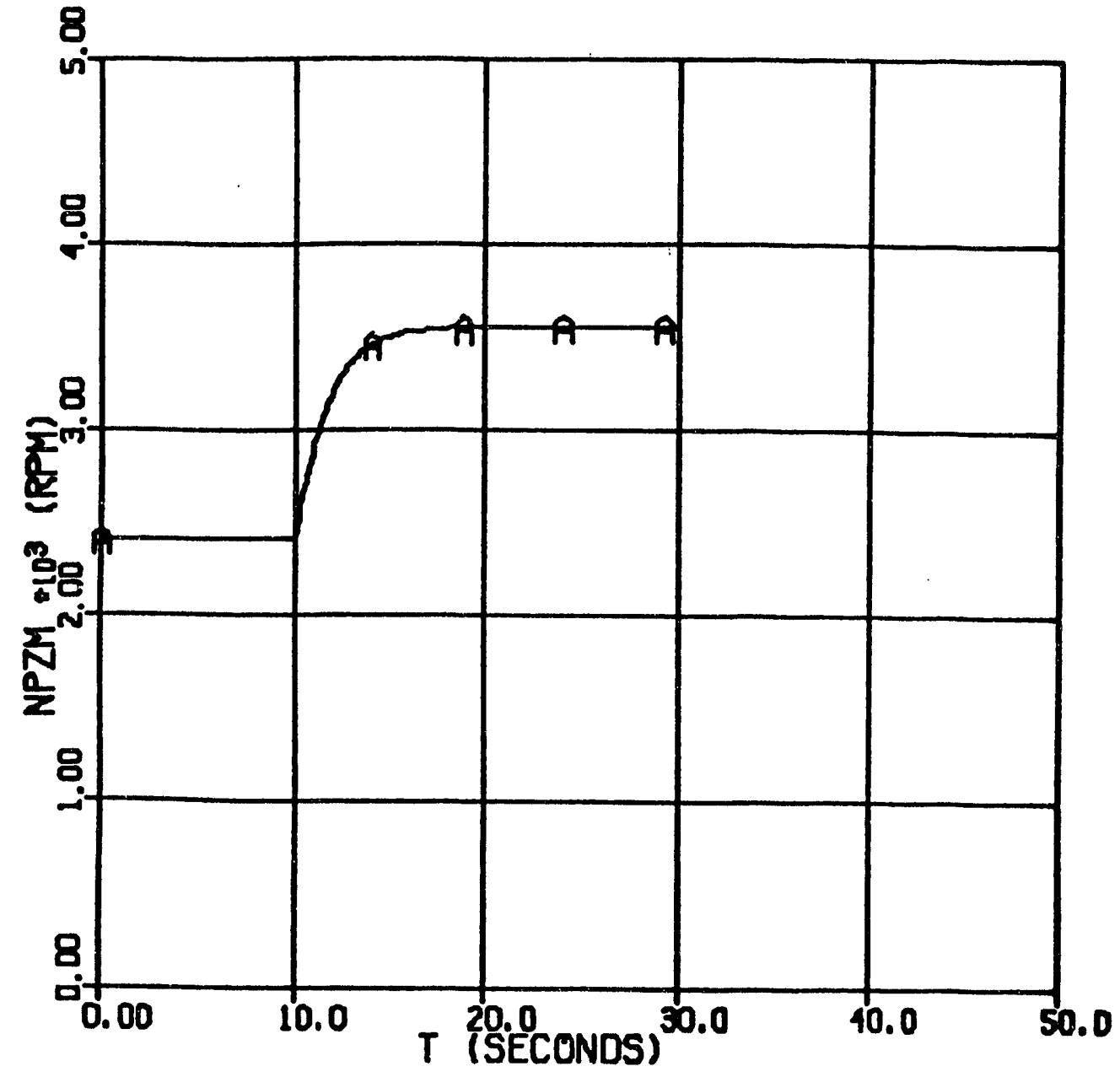

Fig. 3b2.1. The pressurizer pump speed for pressurizer pump overspeed transient case $3 b 2$.

$$
\begin{aligned}
\mathbf{N P Z M} & =\text { pressurizer pump speed }(\mathrm{rpm}) \quad \text { - curve } A \\
\mathbf{T} & =\text { time }(s)
\end{aligned}
$$


The maximum pressurizer pump speed was $3560 \mathrm{rpm}$ and the reactor inlet plenum pressure rose as high as 712 psia (Fig. 3b2.2). The reactor outlet pressure is also shown in the figure. One relief valve opened to decrease the primary coolant system pressure (Fig. 3b2.3). It is a built-in assumption about availability of the relief valves. The letdown valve positions do not change as required by the constraints imposed on the transient. The block valves were also required to close conservatively in $4 \mathrm{~s}$ after the primary system pressure fell below the block valve closure set point. Due to disabled pressurizer pump trips, the primary coolant system pressure stayed high and the relief valve remained open in this transient. The pressurizer pump and letdown flow rates are shown in Fig. 3b2.4. The calculation was stopped at about $30 \mathrm{~s}$. If the calculation were continued, the pressurizer pump would have tripped at low primary coolant head tank capacity $(<25 \%)$. Due to $4 \mathrm{~s}$ delay in the block valve closure time, the pressure would have fallen below reactor trip set point, causing the reactor and secondary side to trip. The auxiliary pressurizer pump would have come on due to low pressurizer pump discharge flow. Note that if the block valves were assumed to close instantaneously, they would have closed at $407.7 \mathrm{psia}$. This might have resulted in no reactor trip until the primary pressure falls below the reactor trip set point due to leakage. The maximum values of some of the system variables are listed in Table 12.

Table 12. The maximum values of the several system variables for case $3 \mathbf{b} 2$

\begin{tabular}{lc}
\hline \multicolumn{1}{c}{ Variable } & $\begin{array}{c}\text { Maximum } \\
\text { valve }\end{array}$ \\
\hline Relief valve flow, gpm & 302 \\
Pressurizer pump discharge pressure, psia & 840 \\
Inlet plenum pressure, psia & 712 \\
Main circulation pump discharge pressure, psia & 735 \\
Letdown flow, gpm & 147 \\
Pressurizer pump flow, gpm & 451 \\
\hline
\end{tabular}

The primary coolant system remains pressurized near 700 psia in this transient. The pressurizer pump will eventually trip on low primary coolant head tank capacity if no operator action is taken.

According to the results of the transients analyzed so far, the performance of the relief valve is rather crucial for preventing the primary system pressure from rising above the set point pressure of the relief valve. To further investigate the influence of the relief valve on the primary coolant system maximum pressure, several additional computations including only one half open relief valve were performed and reported in the following section. 


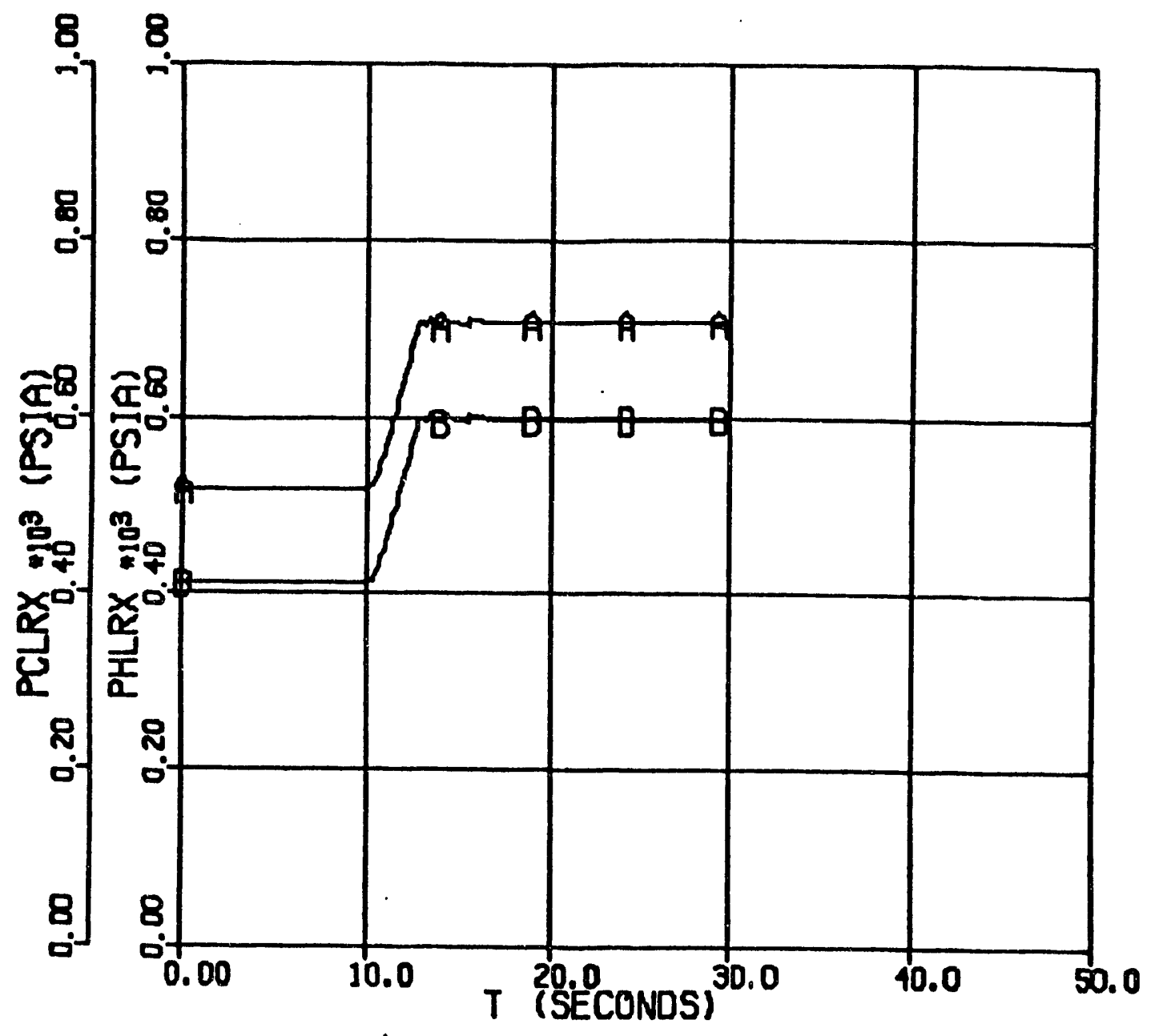

Fig. 3b2.2. The reactor inlet and outlet pressures for pressurizer pump overspeed transient case $3 \mathrm{~b} 2$.

$$
\begin{aligned}
& \text { PCLRX = inlet plenum pressure (psia) - curve A } \\
& \text { PHLRX = outlet plenum pressure (psia) - curve B } \\
& T=\text { time (s) }
\end{aligned}
$$




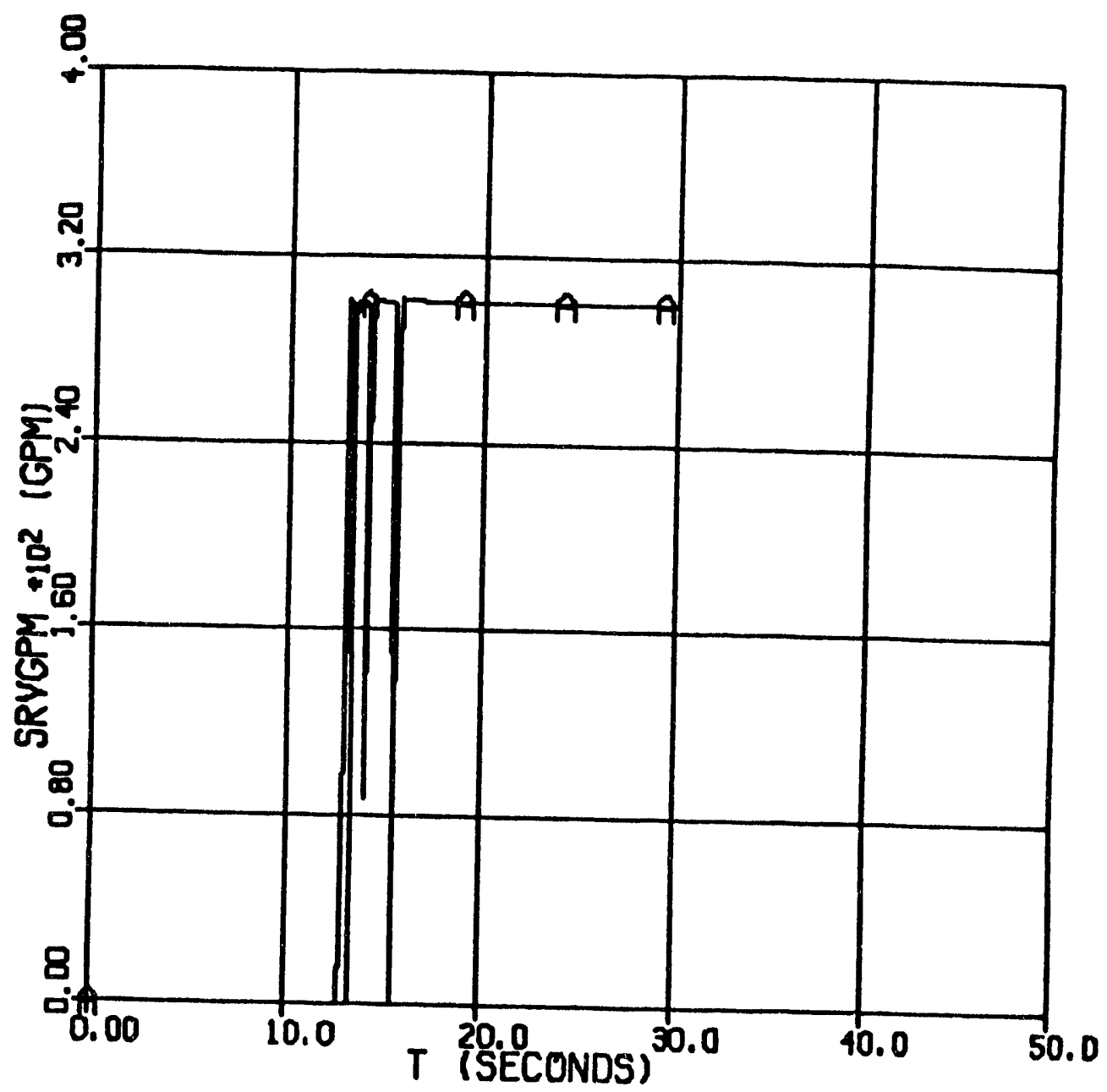

Fig. 3b23. The relief valve flow rate for pressurizer pump overspeed transient case $3 \mathrm{~b} 2$.

SRVGPM = relief valve flow $(\mathrm{gPm})$

- curve A

T $\quad=$ time (s) 


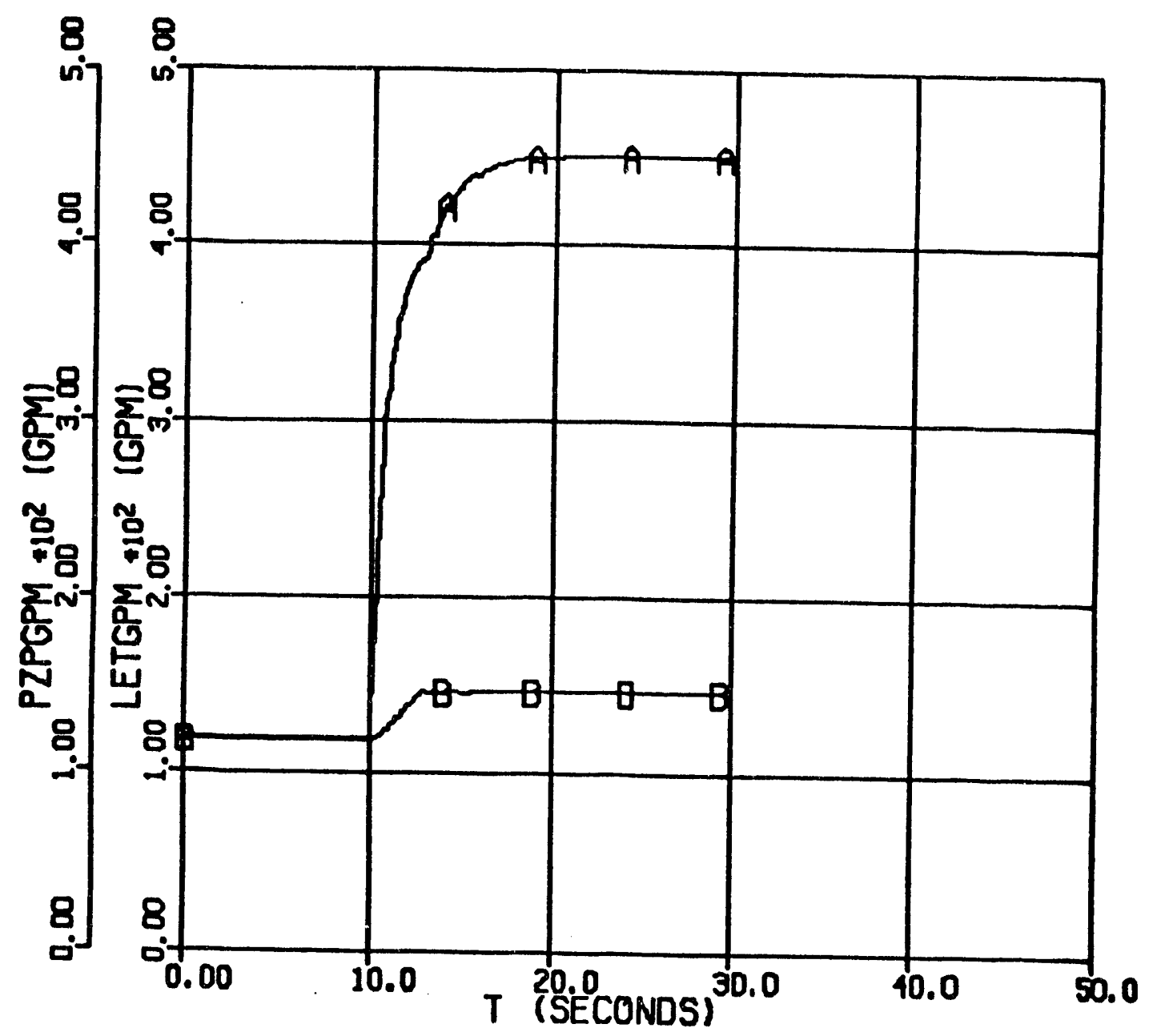

Fig. 3b2.4. The pressurizer pump and letdown flow rates for pressurizer pump overspeed transient case $3 \mathrm{~b} 2$.

$$
\begin{aligned}
& \text { PZPGPM = pressurizer pump flow (gpm) - curve A } \\
& \text { LETGPM = letdown flow (gpm) - curve B } \\
& \mathrm{T} \quad=\text { time (s) }
\end{aligned}
$$




\subsubsection{Effects of Partially Open Relief Valve and Valve Characteristics}

The pressurizer pump overspeed transients result in high primary coolant system pressures challenging the relief valves to open. As an additional sensitivity study, three more calculations were performed. The initial conditions of Case $3 \mathrm{~b} 2$ were the initial conditions in these calculations; however, the valve characteristics for the relief valves were different in each computation. Only one relief valve was allowed to open as in the previous cases. The relief valve position was not allowed to exceed 50\% opening thereby making valve characteristics the controlling key parameter of the outcome. The calculated results confirm this point. The calculations were named $3 b 2 a 7,3 b 2 b 7$ and $3 b 2 c 7$. The reactor inlet and outlet pressures of each case are presented in Fig. 3b2a7.1, 3b2b7.1, and 3b2c7.1. The relief valve flow rates for the three cases are presented in Fig. 3b2a7.2, 3b2b7.2, and $3 b 2 c 7.2$. Rather then repetitively summarizing the similar progress of each transient, the transient name (case), the valve characteristic, and maximum reactor inlet plenum pressure and relief valve flow rates calculated are listed in Table 13.

Table 13. The maximum inlet plenum pressures and relief valve flow rates for cases $3 b 2 a 7,3 b 2 b 7$, and $3 b 2 c 7$

\begin{tabular}{clcc}
\hline Case & \multicolumn{1}{c}{$\begin{array}{c}\text { Valve } \\
\text { characteristics }\end{array}$} & $\begin{array}{c}\text { Maximum inlet } \\
\text { plenum pressure } \\
\text { (psia) }\end{array}$ & $\begin{array}{c}\text { Maximum relief } \\
\text { valve flow } \\
(\mathrm{gpm})\end{array}$ \\
\hline 3b2a7 & Equal percentage & 1081 & 49.2 \\
3b2b7 & Linear & 926 & 174.5 \\
3b2c7 & Quick Opening & 709 & 299.5 \\
\hline
\end{tabular}

Since the quick opening valve reaches almost full flow at $50 \%$ opening, it tends to keep the primary system pressure low. The above results have a guidance value in making decisions for those cases in which the relief valve may be assumed or expected to remain fluttering about half open position or chattering throughout the transient.

\subsubsection{Effects of $\mathrm{K}_{w}$ (Back Pressure Ratio)}

The manufacturer's equation for calculating the rated flow through the relief vaive includes a parameter designated as the flow factor $\left(\mathrm{K}_{\mathrm{w}}\right)$. This parameter multiplies the flow rate directly and its magnitude depends on the back pressure percent. In the HFIRSYS model, internals of the relief valve is not modelled so that the region above the disk filled with the fluid can not be distinguished from the body bowl and discharge regions (i.e. the pressure is the same throughout these regions). The back pressure ratio is the ratio of the pressure on the portion of the upper surface of the disk in contact with the fluid or discharge pressure in this case to the inlet pressure multiplied by 100 . The flow factor $K_{w}$ was assumed to be equal to unity (1) corresponding to a small back pressure ratio around 1 to $15 \%$ in the preceding calculations: $1 \mathrm{a} 1,1 \mathrm{~b} 1,3 \mathrm{a} 1,3 \mathrm{~b} 1,3 \mathrm{a} 2,3 \mathrm{~b} 2,3 \mathrm{~b} 2 \mathrm{a} 7,3 \mathrm{~b} 2 \mathrm{~b} 7$, and $3 \mathrm{~b} 2 \mathrm{c} 7$. To estimate 


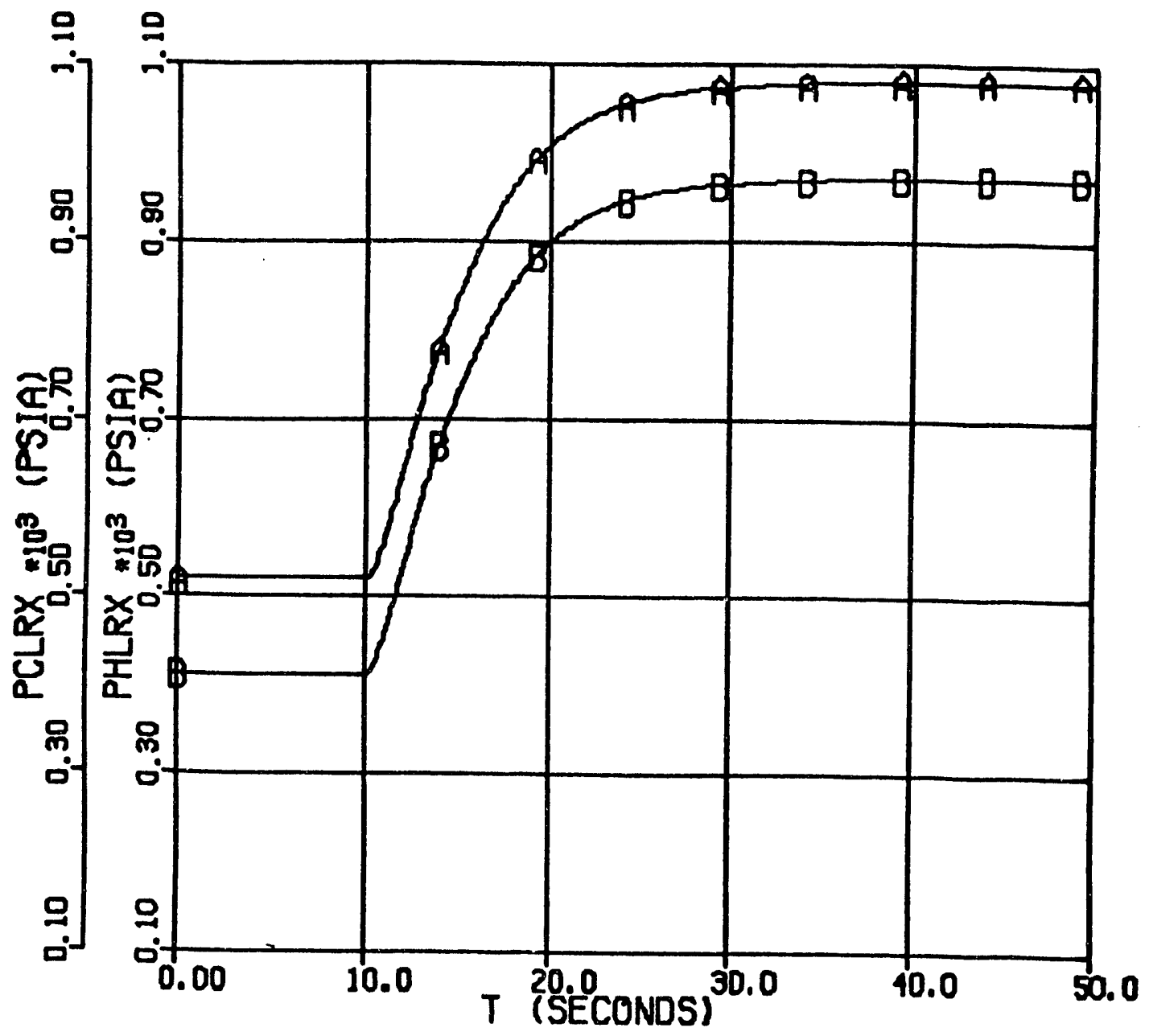

Fig. 3b2a7.1. The reactor inlet and outlet pressures for pressurizer pump overspeed transient case $3 \mathrm{~b} 2 \mathrm{a} 7$.

$$
\begin{aligned}
& \text { PCLRX }=\text { inlet plenum pressure (psia) } \\
& \text { PHLRX }=\text { outlet plenum pressure (psia) } \\
& \begin{array}{ll}
\text { T } & \text { - curve A } \\
& =\text { time (s) }
\end{array}
\end{aligned}
$$




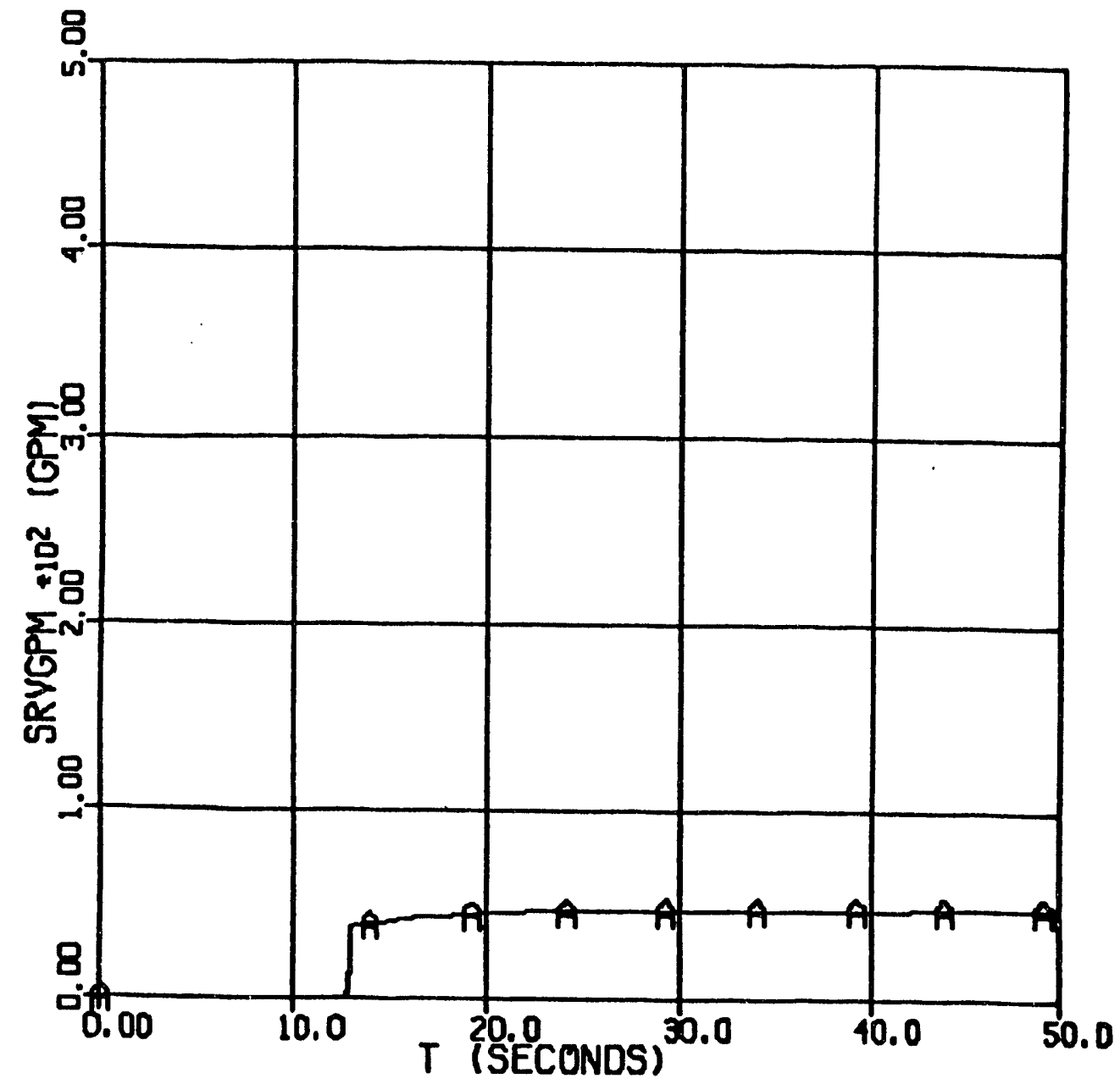

Fig. 3b2a7.2. The relief valve flow rate for pressurizer pump overspeed transient case $3 \mathrm{~b} 2 \mathrm{a} 7$.

$$
\begin{array}{lll}
\text { SRVGPM } & =\text { relief value flow }(\mathrm{gpm}) \quad \text { - curve } \mathbf{A} \\
\mathbf{T} & =\text { time }(\mathrm{s})
\end{array}
$$




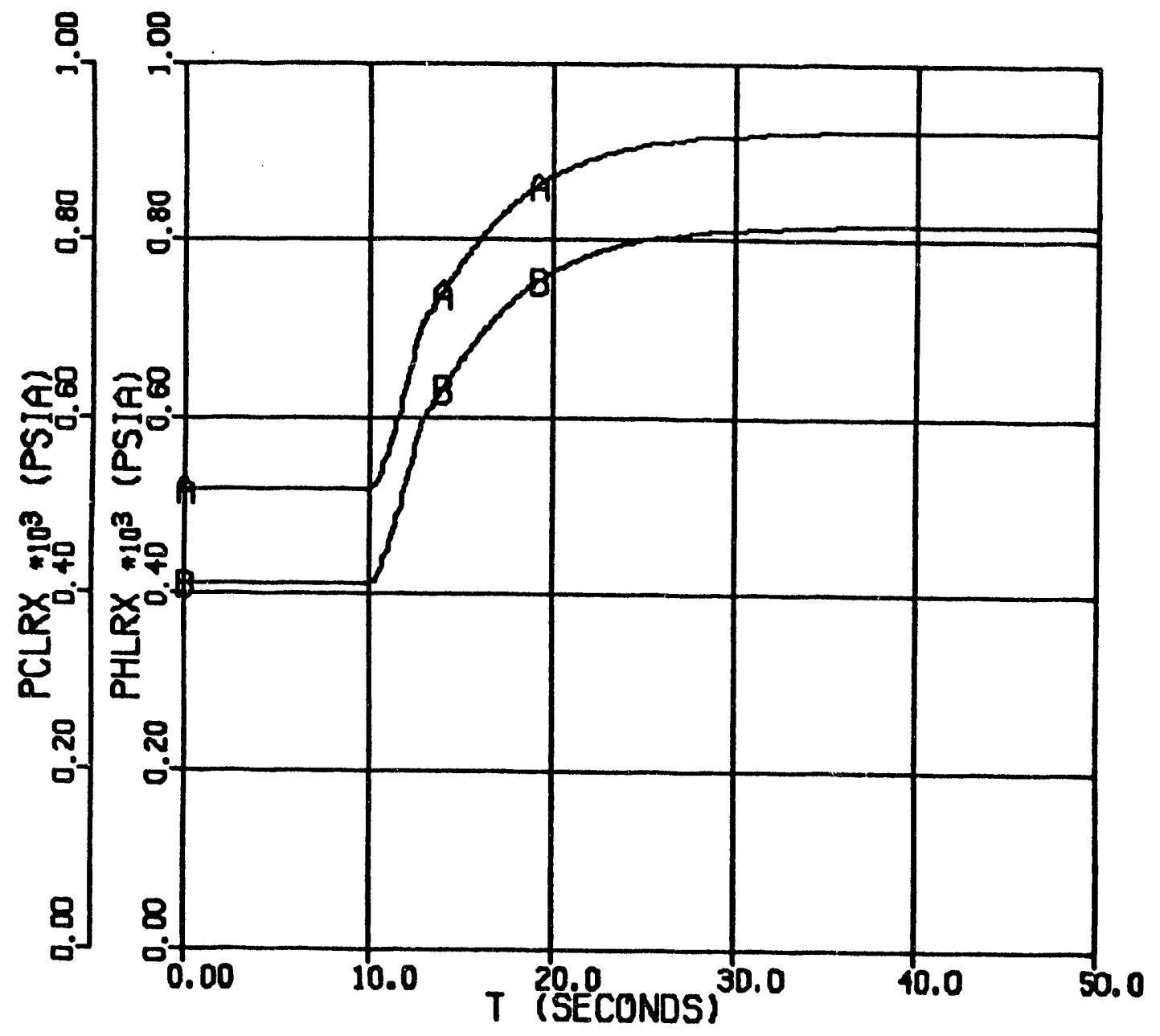

Fig. 3b2b7.1. The reactor inlet and outlet pressures for pressurizer pump overspeed transient case $3 \mathrm{~b} 2 \mathrm{~b} 7$.

$$
\begin{aligned}
& \text { PCLRX = inlet plenum pressure (psia) - curve A } \\
& \text { PHLRX = outlet plenum pressure (psia) - curve B } \\
& \mathrm{T} \quad=\text { time (s) }
\end{aligned}
$$




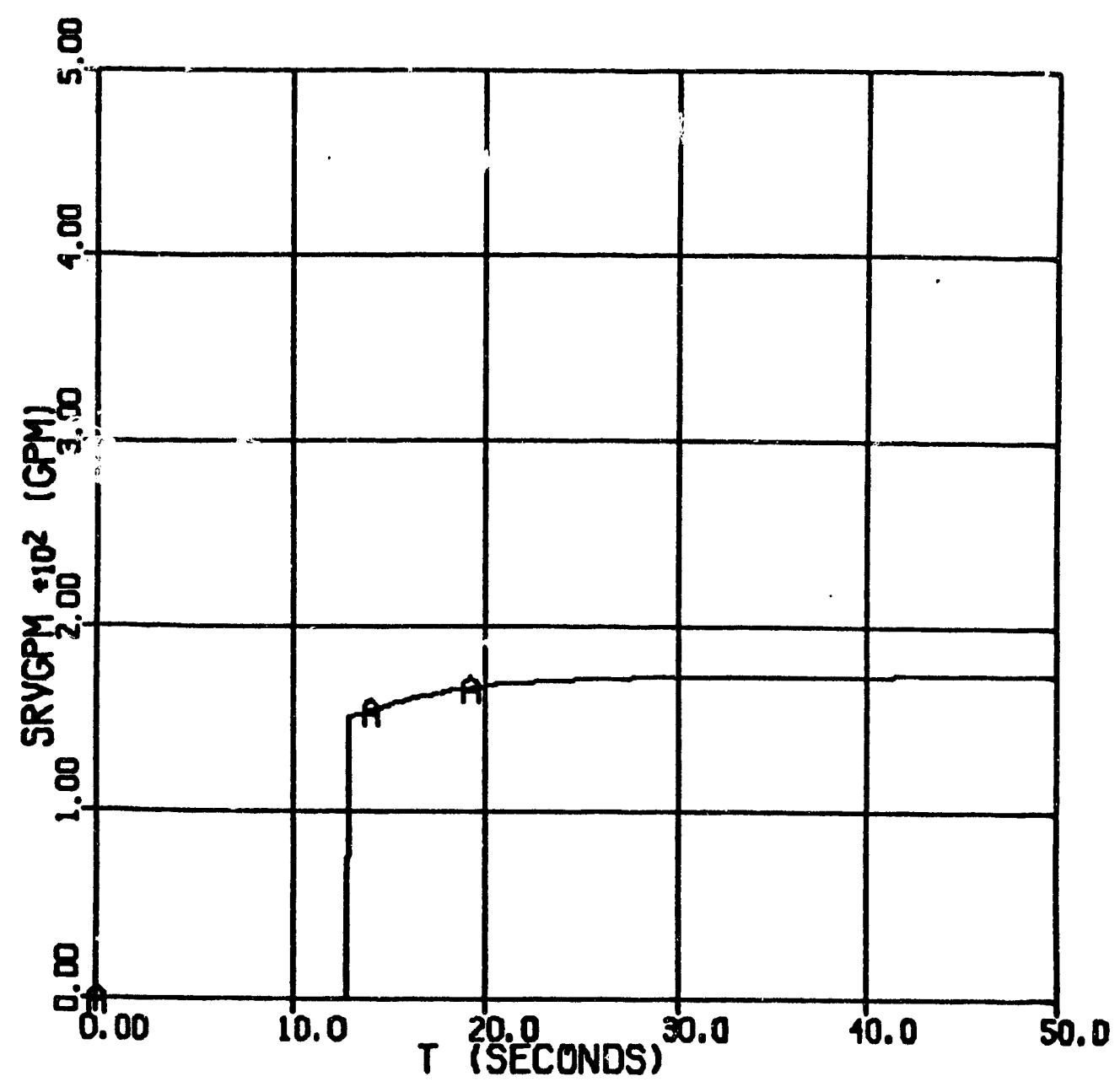

Fig. 3b2b7.2 The relief valve flow rate for pressurizer pump overspeed transient case $3 \mathrm{~b} 2 \mathrm{~b} 7$.

$$
\begin{array}{lll}
\text { SRVGPM } & =\text { relief valve flow }(\text { gpm }) \quad \text { - curve } \mathbf{A} \\
\mathbf{T} & =\text { time }(s)
\end{array}
$$




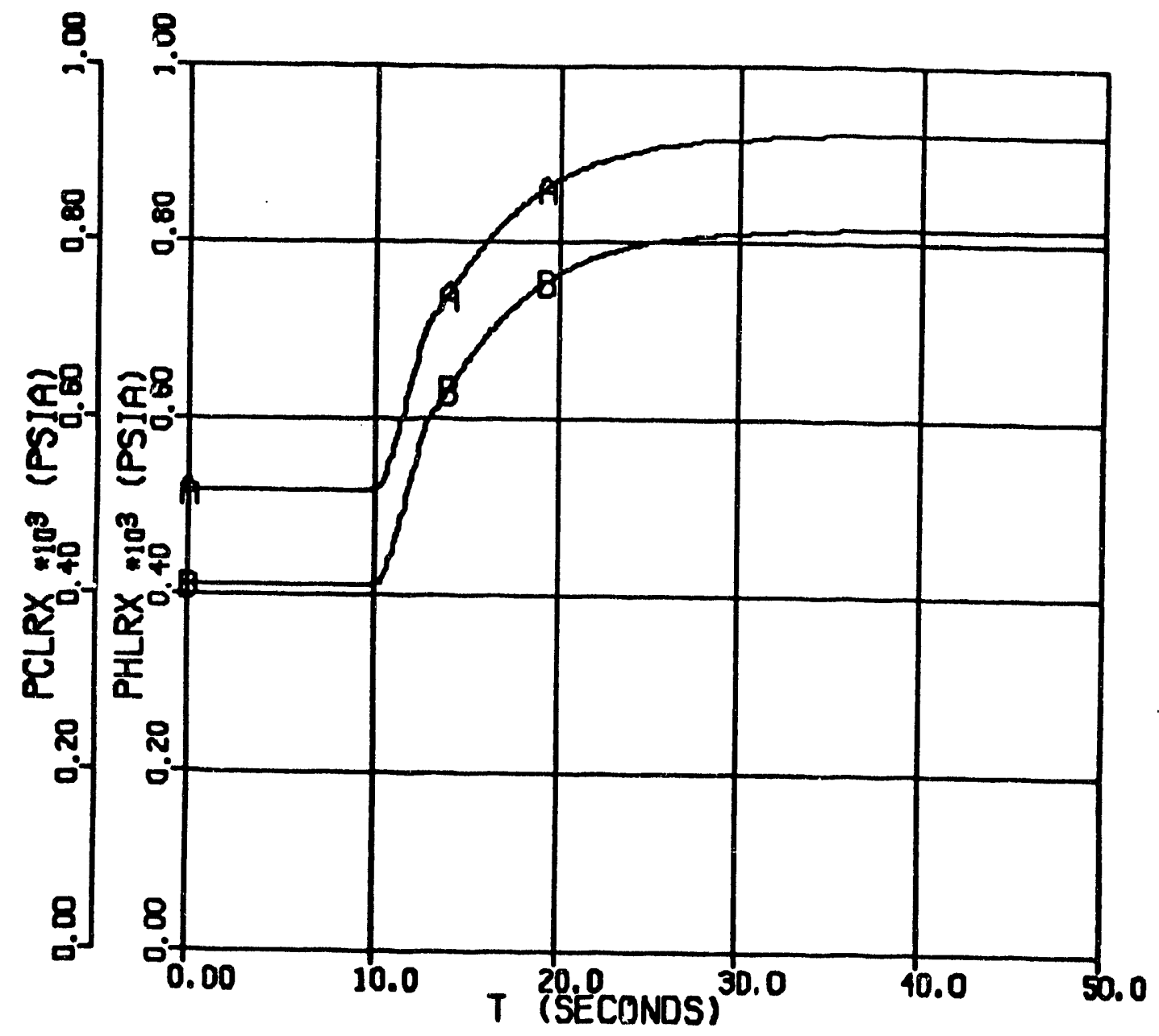

Fig. 3b2c7.1. The reactor inlet and outlet pressures for pressurizer pump overspeed transient case 3b2c7.

$$
\begin{aligned}
& \text { PCLRX = inlet plenum pressure (psia) } \\
& \text { PHLRX = outlet plenum pressure (psia) } \\
& \text { T } \quad \text { curve A } \\
& \quad \text { time (s) }
\end{aligned}
$$




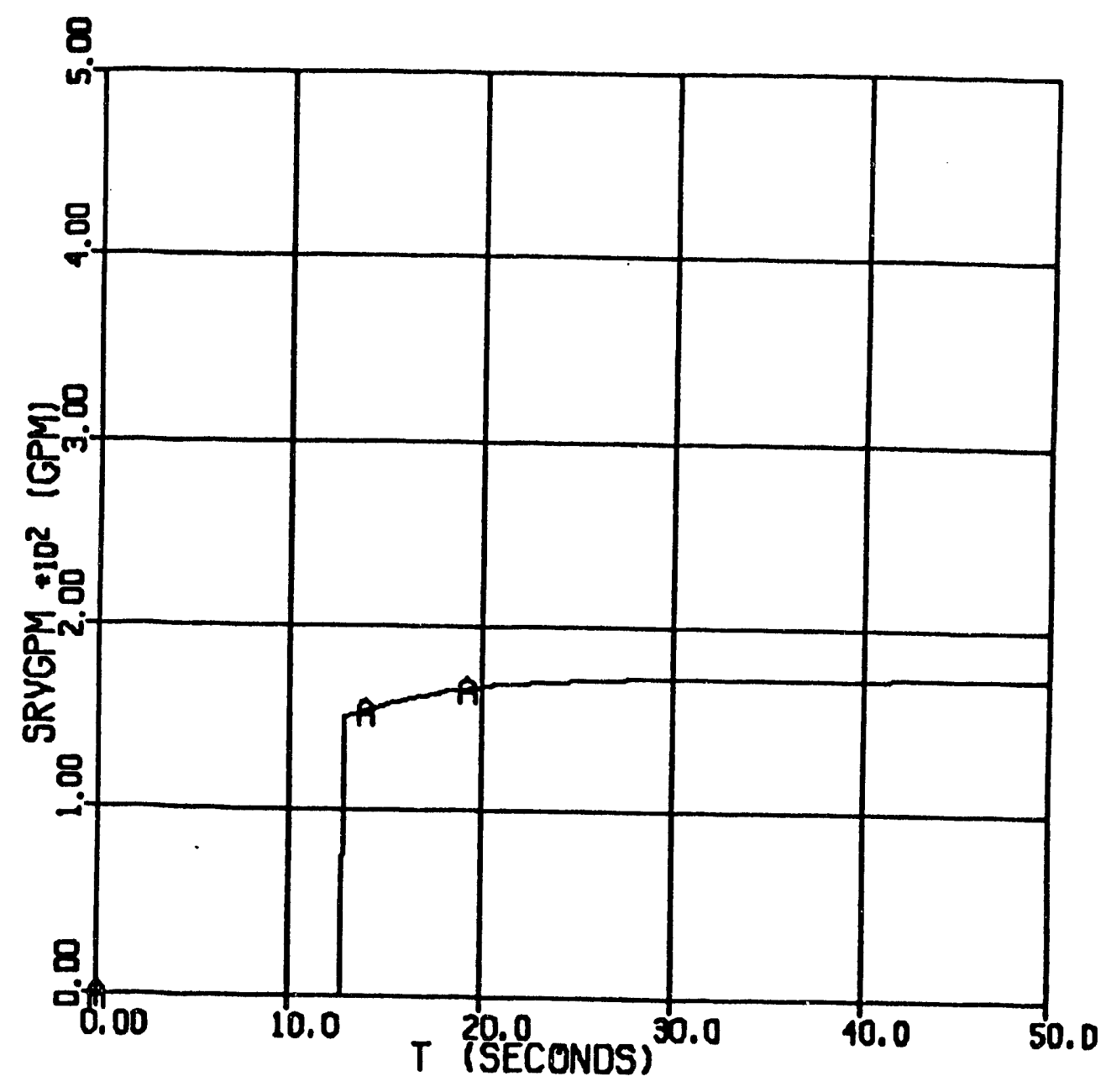

Fig. $3 b 2 c 7.2$ The relief valve flow rate for pressurizer pump overspeed transient case $3 b 2 c 7$.

$$
\begin{aligned}
\text { SRVGPM } & =\text { relief valve flow }(\mathrm{gpm}) \quad \text { - curve A } \\
\mathbf{T} & =\text { time }(\mathrm{s})
\end{aligned}
$$


effects of this factor on the primary coolant system pressure, the back pressure percent was assumed to be about $50 \%$ which has no bases. (During the transient the back pressure may oscillate causing the $\mathrm{K}_{\mathrm{w}}$ factor to vary.) At $50 \%$ back pressure percentage, the $\mathrm{K}_{\mathrm{w}}$ factor is equal to 0.675 . ${ }^{20}$ This reduces the rated flow $\left(296 \mathrm{gpm}\right.$ calculated with $\left.\mathrm{K}_{\mathrm{w}}=1\right)$ down to 67.5\%. A new flow conductance was calculated based on the new rated flow (about $200 \mathrm{gpm}$ ) at 682 psi pressure drop through the relief valve. A value of $62 \mathrm{lb}_{\mathbf{m}} / \mathrm{ft}^{3}$ was assumed for the water density:

$$
\text { KCVSRV }=\frac{199.8 \mathrm{gpm} 60 \frac{\mathrm{min}}{\mathrm{h}} 0.1337 \frac{\mathrm{ft}^{3}}{\mathrm{gal}} 62 \frac{\mathrm{lb} \mathrm{w}}{\mathrm{ft}^{3}}}{\left(62 \frac{\mathrm{lb}}{\mathrm{ft}^{3}} 682 \mathrm{psi}\right)^{-\frac{1}{2}}}=483.26 \frac{\mathrm{lb}}{\mathrm{h}}\left(\frac{\mathrm{lb}}{\mathrm{ft}^{3}} \mathrm{psi}\right)^{-\frac{1}{2}}
$$

This value is rather very conservative especially when compared to the back pressure ratio estimated from calculated pressure drop for the downstream pipe at the rated flow (296 gpm). This estimate clearly implies that the valve outlet, body bowl, and back pressures are equal in the model. The calculated downstream piping pressure losses is about 4.44 psi and the primary coolant head tank pressure is 14.7 psia when it is empty. Then a back pressure can be estimated based on the implication that the valve outlet pressure and the back pressure are approximately equal: $4.44+14.7=19.14$ psia. The back pressure percentage for the relief valve opening pressure equal to 703.7 psia is:

$$
\text { Back pressure percentage }=\frac{19.14 \text { psia }}{703.7 \text { psia }} 100=2.7 \%
$$

This percentage (2.7\%), which corresponds to approximately $\mathrm{K}_{\mathrm{w}}=1$, is much smaller than the assumed value $50 \%$. Nevertheless the conservative value of the flow conductance was used to recalculate the transient $(3 \mathrm{~b} 2)$ in order to estimate a relatively high limit for the inlet plenum pressure. This transient is named $362 \mathrm{kw}$. The initial conditions and the progress of the transient were similar to those reported in the preceding section. The relief valve characteristic is the equal percentage type, the same as in $3 \mathrm{b2}$. Low flow rates through the relief valve in the full open position were calculated at similar pressure drops because the magnitude of $\mathrm{K}_{\mathrm{w}}$ is less that in $3 \mathrm{~b} 2$.

Because the primary coolant can not be released fast enough in this case, the reactor inlet plenum pressure rises to 850 psia which is higher than the maximum reactor inlet plenum pressure 712 psia calculated in case $3 \mathrm{~b} 2$. The pressurizer pump speed is presented in Fig. $3 \mathrm{~b} 2 \mathrm{kw} .1$, the reactor inlet and outlet pressures in Fig. $3 \mathrm{~b} 2 \mathrm{kw} .2$, the relief valve flow rate in Fig. 3b2kw.3, and the pressurizer pump and letdown flow rates in Fig. 3b2kw.4. The results are summarized in Table 14. 


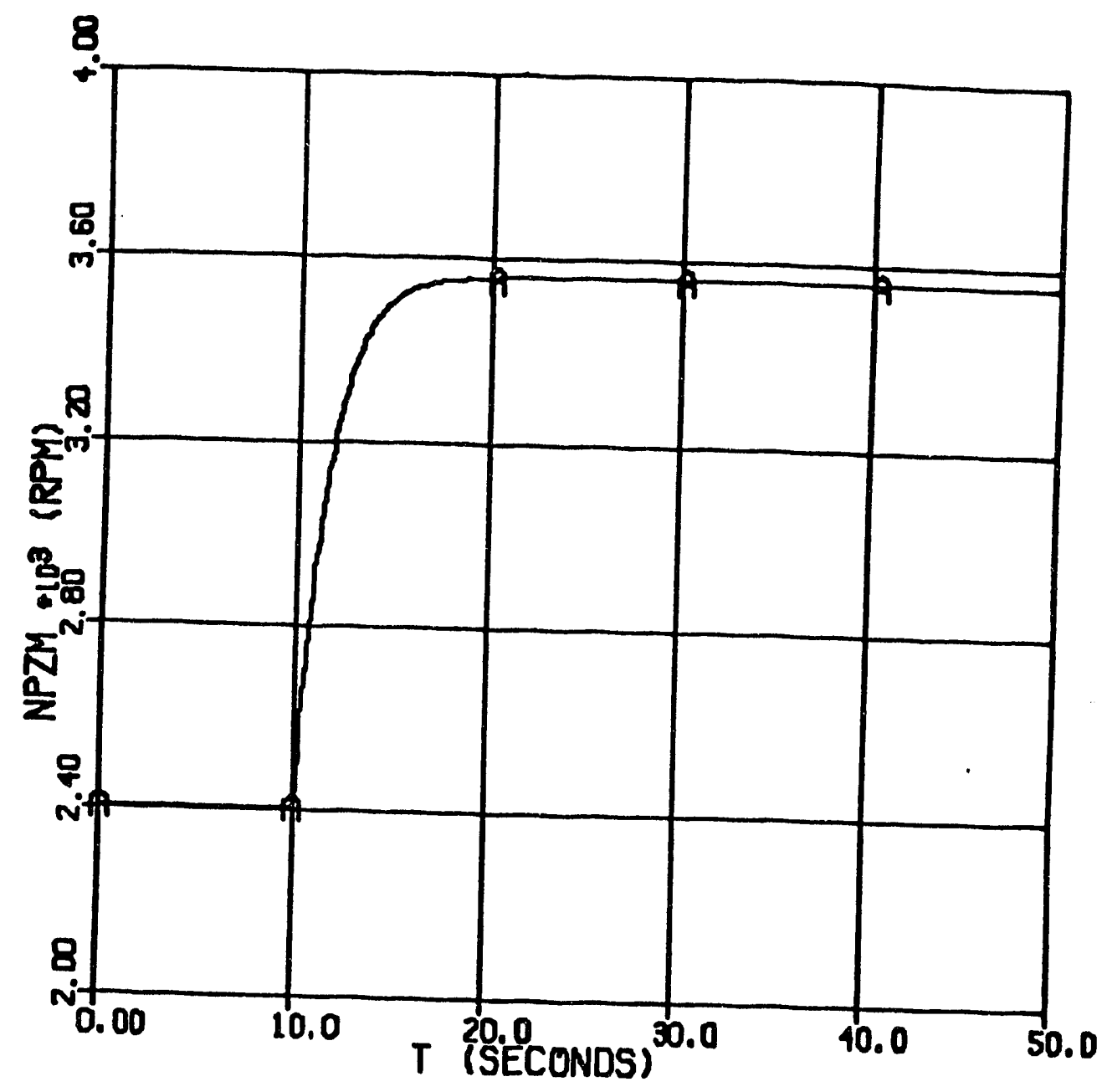

Fig. 3b2kw.1. The pressurizer pump speed for pressurizer pump overspeed transient case $3 b 2 k w$.

$$
\begin{aligned}
& \text { NPZM }=\text { pressurizer pump speed }(\mathbf{r p m}) \quad \text { - curve } \mathbf{A} \\
& \mathbf{T}=\text { time (s) }
\end{aligned}
$$




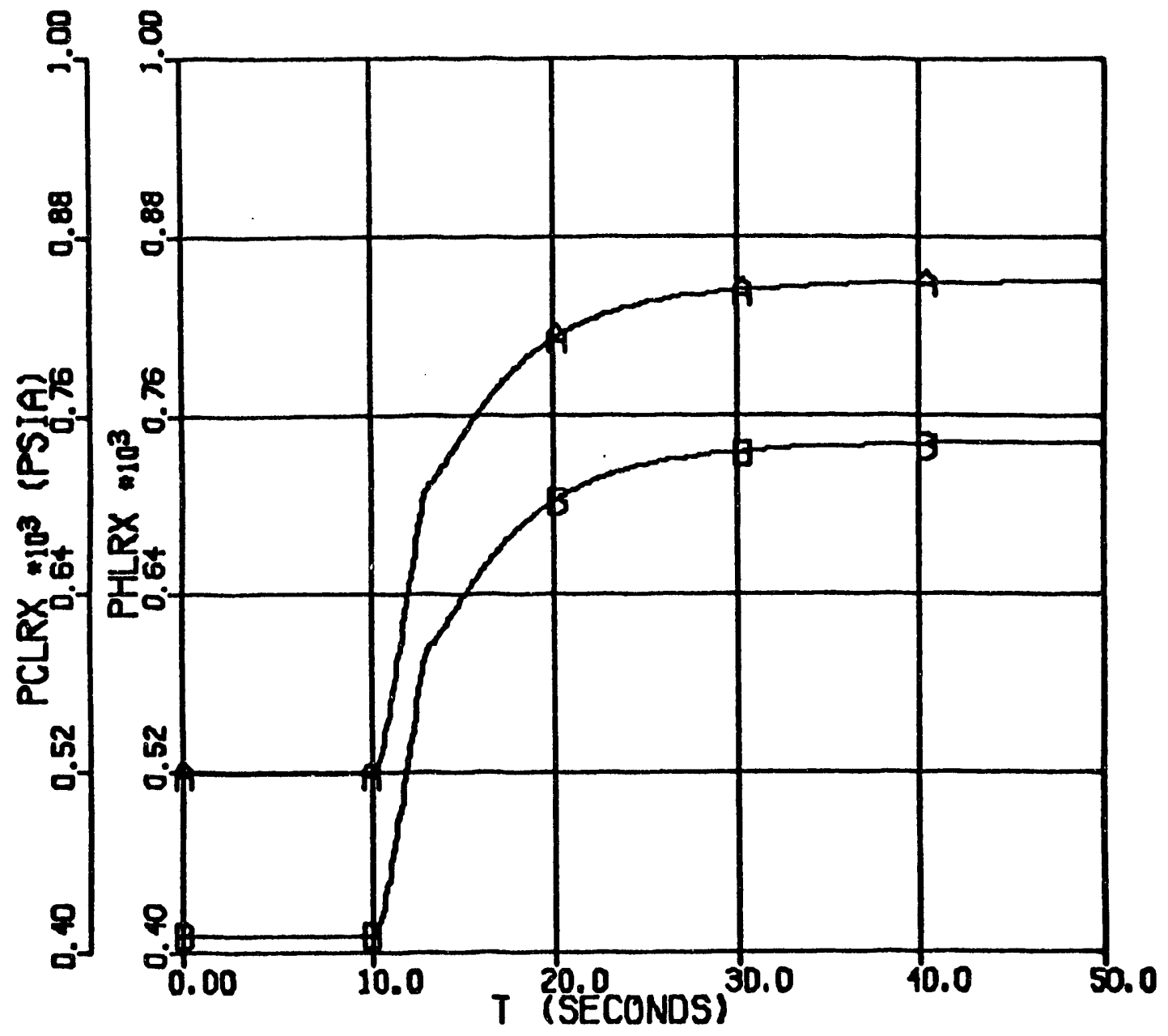

Fig. $362 k w .2$. The reactor inlet and outlet pressures for pressurizer pump overspeed transient case $3 \mathrm{~b} 2 \mathrm{kw}$.

$$
\begin{aligned}
& \text { PCLRX = inlet plenum pressure (psia) - curve A } \\
& \text { PHLRX = outlet plenum pressure (psia) - curve B } \\
& \mathrm{T} \quad=\text { time (s) }
\end{aligned}
$$




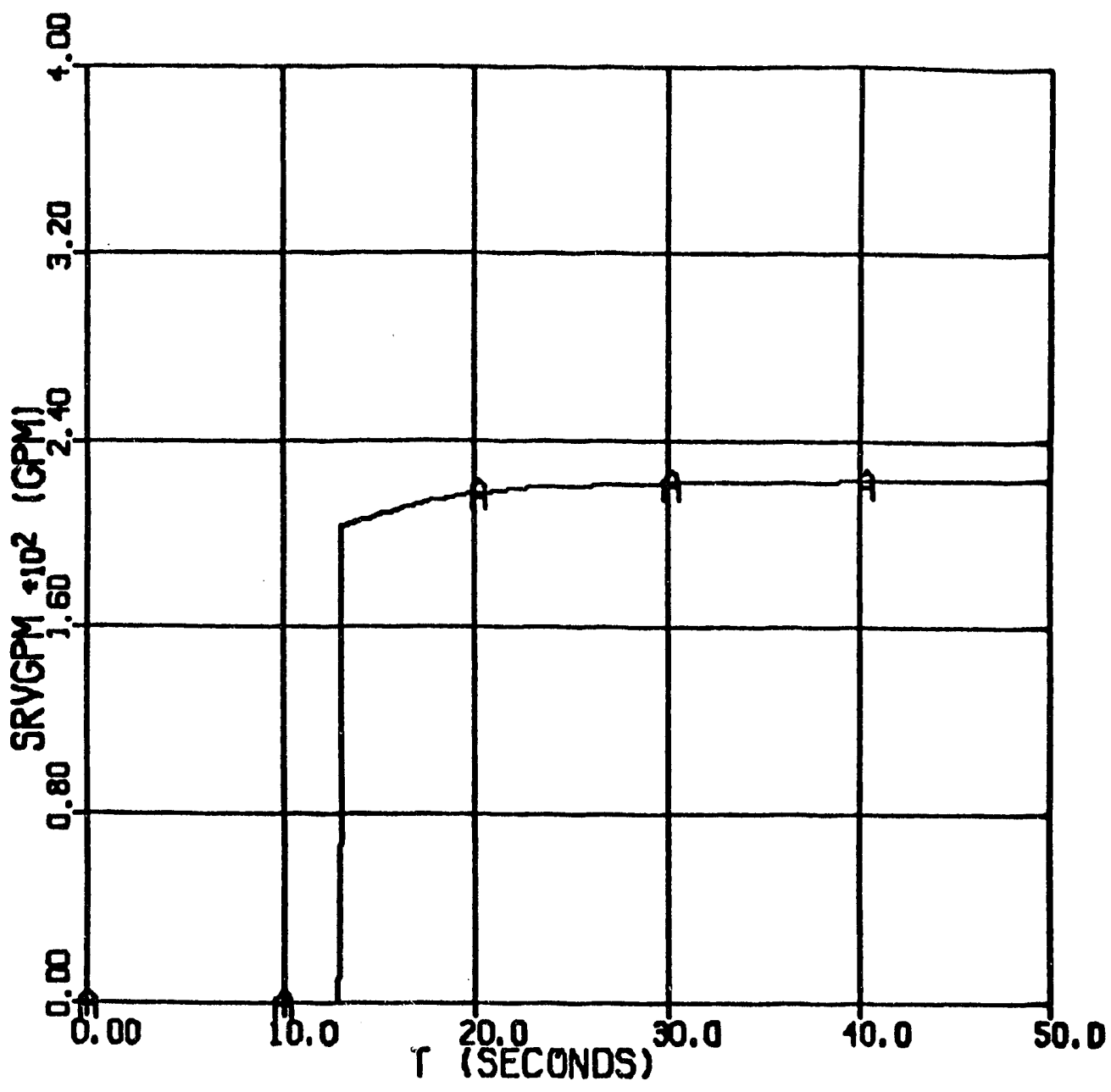

Fig. 3b2kw.3. The relief valve flow rate for pressurizer pump overspeed transient case $3 \mathrm{~b} 2 \mathrm{kw}$.

$$
\begin{array}{lll}
\text { SRVGPM } & =\text { relief value flow }(\mathrm{gpm}) \quad \text { - curve A } \\
\mathbf{T} & =\text { time }(\mathrm{s})
\end{array}
$$




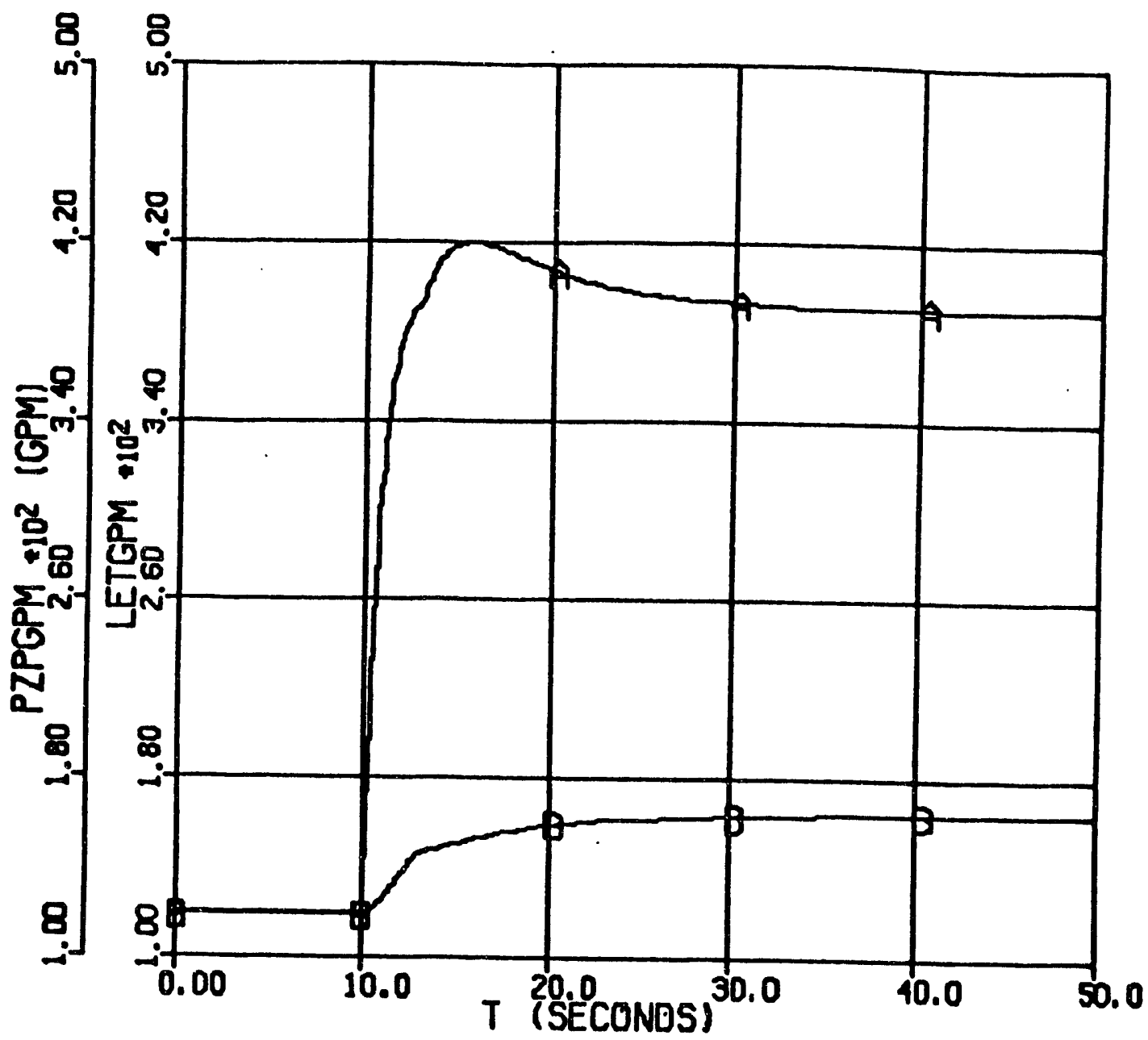

Fig. 3b2kw.4. The pressurizer pump and letdown flow rates for pressurizer pump overspeed transient case $3 \mathrm{~b} 2 \mathrm{kw}$.

$$
\begin{array}{rlr}
\text { PZPGPM } & =\text { pressurizer pump flow (gpm) } & \text { - curve A } \\
\text { LETGPM } & =\text { letdown flow (gpm) } & \text { - curve B } \\
\text { T } & =\operatorname{time~(s)~} &
\end{array}
$$


Table 14. The maximum values of the several system variables for case $3 \mathbf{b} 2 \mathbf{k w}$

\begin{tabular}{lc}
\hline \multicolumn{1}{c}{ Variable } & $\begin{array}{c}\text { Maximum } \\
\text { valve }\end{array}$ \\
\hline Relief valve flow, gpm & 222.7 \\
Pressurizer pump discharge pressure, psia & 957 \\
Inlet plenum pressure, psia & 850 \\
Main circulation pump discharge pressure, psia & 870 \\
Letdown flow, gpm & 165 \\
Pressurizer pump flow, gpm & 420 \\
\hline
\end{tabular}

The primary coolant storage tank pressure was allowed to change based on accumulated discharge coolant through the relief valve system. The static pressure in the tank increased from 14.7 psia to 15.9 psia in about $40 \mathrm{~s}$. This is a negligible increase. The same calculation was also performed with the primary coolant storage tank pressure equal to 14.7 psia. The values listed in the above table virtually remained unchanged. For all practical purposes, the primary coolant storage tank pressure may be assumed constant for short duration calculations. In applications, a $K_{w}$ value $<1$ may be preferred when no data is available for back pressure. Although correlations were provided for calculation of back pressure of certain relief valves, ${ }^{6}$ it is not clear whether or not the correlations for calculation of the back pressure is valid when the adjusting and nozzle ring positions are altered. The correlations do not include ring positions. Changing positions of the adjusting and nozzle rings changes the flow area and the discharge angle between the inlet nozzle and the body bowl. 


\section{INDEPENDENT RELIEF VALVE SUBSYSTEM MODEL}

The HFIRSYS computer program including the relief valves and the primary coolant storage tank but not including the relief valve piping as separate nodes was used to perform the pressurizer pump overspeed transient calculations. (The flow resistance of the upstream and downstream piping was incorporated into the relief valve module.) The transient simulations and their analysis are reported in the preceding section. The pressure waves generated during opening and closing of the relief valve were assumed not to affect the relief valve performance and stability in those calculations. Independent relief valve subsystem models were developed for a detailed analysis of the relief valve subsystem as required by the physics of the interactions involved. These independent models are described in this section.

\subsection{MODEL DESCRIPTION}

The expansion (during opening of the valve) and compression (during closing of the valve) waves cause rapid decreases and increases in the inlet pressure of the valves. If oscillations in the inlet pressure continue, the relief valve will respond to this changes by perhaps chattering or fluttering. To analyze interactions between flow, pressure, and valve position, a separate model was developed based on the Modular Modeling System (MMS) code. ${ }^{16}$ The model includes piping from the cold leg to the relief valves and the piping from the relief valves to the primary coolant storage tank. The relief valve and the primary coolant storage tank models are also included. The primary coolant system pressure and temperature are represented as the boundary conditions at the location where the relief valve upstream piping is attached to the cold leg. Note that due to lack of data about the relief valve spring force, guide ring positions, capacity correction factor due to back pressure, relationship between the relief valve bowl (chamber) pressure and back (discharge or exit) pressure, weight of the valve stem and other geometric information about the internal areas and openings, a new relief valve model was not developed to simulate valve stem movements based on the forces imposed on it. The valve position is allowed to change at reimposed constant rates. The position changing rates are calculated based on the selected opening or closing time.

The flow factor based on back pressure ratio $\left(\mathrm{K}_{\mathrm{w}}\right)$ described in Sect. $5.3 \mathrm{~b} 2.2$ significan: $! y$ affects the flow through the valve. The $\mathrm{K}_{\mathrm{w}}$ factor used in the manufacturer's equation for calculating the relief valve capacity ${ }^{19}$ represents the flow reduction based on the back pressure percentage. The relief valve rated capacity is calculated from

$$
G P=\frac{28.14 A K_{w} K_{V} \Delta P^{1 / 2}}{G^{1 / 2}}
$$


where

$$
\begin{aligned}
A & =\text { effective discharge area }=0.503 \mathrm{in}^{2} \text { for "G" orifice, } \\
\mathrm{G} & =\text { specific gravity of the liquid at flowing conditions, } \\
\mathrm{GPM} & =\text { relief capacity in U.S. gallons per minute }(\mathrm{gpm}) \text { at flowing temperature } \\
\mathrm{K}_{\mathrm{v}} & =\text { flow correction factor due to viscosity of the fluid conditions, and } \\
\Delta \mathrm{P} & =\text { differential pressure (psi) } \\
& =\text { set pressure }+ \text { overpressure - outlet pressure }
\end{aligned}
$$

The rated flow is calculated based on $\mathrm{K}_{\mathrm{w}}=1$ in all of the calculations in this section. Effects of variations in the back pressure ratio are not separately analyzed. However, significance of the magnitude of this ratio is demonstrated by a significant rise in the primary coolant system pressure in Sect. 5.3b2.2.

The independent relief valve subsystem models require small time steps $\left(10^{-5} \mathrm{~s}\right)$ in order to simulate rapid pressure oscillations with large amplitudes in the relief valve upstream and downstream piping. Pressure waves generated due to changing relief valve position travel between the cold leg connection and the relief valve. The relief valve position reacts to changes in the inlet pressure creating complex interactions of flow, valve position, waves, and wave reflections. It is necessary to discern whether or not one relief valve affects the other's performance if the relief valves open at different set points and the valve positions change at different rates. Having the downstream piping allows inclusion of effects of the pressure changes at the discharge of the valve (back pressure). To develop an understanding of these kind of effects on the relief valve performance and stability, numerous calculations were performed using the relief valve subsystem models. The valve position changing rates corresponding to different opening or closing times for the relief valve are input to the programs. (The relief valves open and close at a constant rate in the model.) The available information about the opening and closing times of the relief valves in the literature were used as a guidance in performing parametric studies. No measured test data on the opening and closing times of the HFIR relief valves are available.

There are two rupture disk/relief valve paths at HFIR. In the following description of the relief valve subsystem models, one or two paths refer to only one path or both of the paths being modeled. Four different relief valve subsystem models were constructed. Each program has two different versions. In the first version whose names do not include numbers such as RELIEF.CSL, the relief valves are directly attached to the main large volume downstream pipe. In the second version whose names include a number, such as RELIE2.CSL, the relief valves are attached to a short downstream pipe which is connected to the large volume main downstream pipe. The independent models are described in Table 15. 
Table 15. The relief valve subsystem models

\begin{tabular}{|c|c|c|}
\hline $\begin{array}{l}\text { Relief valves connected to } \\
\text { main downstream pipe }\end{array}$ & $\begin{array}{l}\text { Relief valves connected to } \\
\text { short downstream pipe }\end{array}$ & $\begin{array}{l}\text { Description } \\
\text { of the model }\end{array}$ \\
\hline RELIEF.CSL & RELIE2.CSL & $\begin{array}{l}\text { One path rupture disk- } \\
\text { relief valve subsystem } \\
\text { model. }\end{array}$ \\
\hline RELVAL.CSL & RELVA2.CSL & $\begin{array}{l}\text { Two-path with one path } \\
\text { having a relief valve that is } \\
\text { always closed. }\end{array}$ \\
\hline RELSVL.CSL & RELSV2.CSL & $\begin{array}{l}\text { Two-path with both paths } \\
\text { open This allows studying } \\
\text { effects of dissimilar } \\
\text { opening and closing rates } \\
\text { and set point pressures of } \\
\text { relief valves on each other. }\end{array}$ \\
\hline \multirow[t]{2}{*}{ RELMAL.CSL } & RELMA2.CSL & $\begin{array}{l}\text { One-path with valve } \\
\text { opening pressure changing } \\
\text { based on the valve's inlet } \\
\text { and outlet pressure. The } \\
\text { fluid pressure on the upper } \\
\text { surface of the disk acting } \\
\text { downward on the stem was } \\
\text { assumed to be negligible } \\
\text { compared to the outlet } \\
\text { pressure. The valve stem is } \\
\text { not modeled. }\end{array}$ \\
\hline & RELMA3.CSL & $\begin{array}{l}\text { Same as RELMA2.CSL } \\
\text { except for division of the } \\
\text { short downstream pipe into } \\
\text { two nodes. }\end{array}$ \\
\hline
\end{tabular}

The downstream piping ( 4 in. sch 40 , stainless steel) of the rupture disks and the relief valves is connected to the underground primary coolant storage tank that is large enough to hold the entire primary coolant. Pipe module MMS PIPESR ${ }^{16}$ is used in modeling downstream piping. The main upstream piping from the cold leg to the bifurcation point is stainless steel 4-in. sch 40 pipe. The bifurcation point is the junction of two $11 / 2$ in. relief valve inlet piping and the 4-in. upstream pipe. Each $11 / 2$ in. pipe include a rupture disk and a relief path. The main 4-in. upstream pipe is represented by a single MMS PIPERS module. Each $11 / 2$-in. pipe from the bifurcation point to the relief valve is also represented by a single MMS PIPERS module and the relief valve by the MMS VALVEI module. ${ }^{16}$ 
The primary coolant storage tank gas region pressure remains about atmospheric. The geometric data for the tank was taken from (Lepard ${ }^{18}$ ). The tank model keeps track of the water level based on the relief valve discharge into the tank and also the pressure at the bottom of the tank based on the water level. The tank includes two sections, one with a much larger cross sectional area than the other.

The piping from the cold leg to the bifurcation point and from the relief valve to the primary coolant storage tank are the same in all of the programs.

\subsubsection{Modifications to MMS modules}

The MMS PIPERS and PIPESR modules were modified to handle situations in which negative pressures are calculated. During the rapid pressure oscillations, despite the presence of liquid water in nodes, negative pressures were calculated when using original MMS modules. Presence of liquid water at a location requires that the minimum pressure be vapor pressure of the liquid water at that temperature. The pressure falls below the vapor pressure if there is only steam and no liquid water. However it can never be negative. The original modules were modified so that calculated pressures are limited to the vapor pressure of the liquid water in that node. The independent variables in MMS are pressure and enthalpy, and liquid water temperature is calculated based on these parameters when water is subcooled. The water density and density derivatives with respect to enthalpy and pressure are included in the pressure and enthalpy derivative equations. ${ }^{15}$ Therefore, changes in the pressure and enthalpy should affect the liquid water temperature. If there is only steam in pipes, this approach will not provide correct answer.

\subsection{ANALYSIS OF RELIEF VALVE PERFORMANCE AND STABILITY}

The purpose of this section is to analyze effects of the different factors on relief valve performance and stability using relief valve subsystem models. The results of the analyses then can be used in justification of the choices made in modeling pressurizer pump overspeed transients or used as a guidance in improving the model for such transients challenging the pressure relief system. The calculations are categorized into five parts corresponding to five factors which impact relief valve performance and stability. Each category utilizes a specific relief valve subsystem model. 


\subsubsection{Effects of Pressure and Flow Oscillations on Relief Valve Performance}

In order to analyze effects of pressure and flow oscillations on relief valve performance, the relief valve was assumed to open instantaneously at its set point at time zero. This causes the largest reduction in the inlet pressure to set off waves throughout the relief valve piping system. Only one of the relief valves is assumed to be available. After the initial instantaneous opening, the valve opens or closes at a constant rate based on predefined opening or closing time in response to changes in the relief valve inlet pressure. The main purpose is to calculate how long it will take for oscillations to subside and for the relief valve to reach stable fully open position.

The cold leg pressure is the boundary condition in the model. To perform the analysis, the cold leg pressure was set to a value (708 psia) above the relief valve set point equal to 703 psia at time zero. Then the cold leg pressure quickly rises to 720 psia and stays at that value until after the relief valve is stable in fully open position. The cold leg input pressure profile was selected in a way to open to cause the relief valve start opening and become fully open. The pressure waves bouncing off the cold leg cause the relief valve reopen and reclose although the cold leg pressure remains above the relief valve set point pressure. The valve's periodic movements reflect approximately the period of the pressure waves (four times the length of the piping divided by $4500 \mathrm{ft} / \mathrm{s}$, an approximate value for the speed of sound in the inlet piping). The waves created due to rapid changes of the valve position are expected to bounce off the cold leg. The period of the dominant waves are approximately $0.02 \mathrm{~s}$ corresponding to about 50 hertz. The waves with higher frequencies and different amplitudes would also be produced due to $11 / 2$ in. pipe at the inlet of the valves attached to the 4 in. pipe. These occasionally visible high frequency waves (about 480 hertz and $0.002 \mathrm{~s}$ period) reflect off the $4 \mathrm{in}$. pipe and travel back to the relief valve. After the relief valve becomes stable in its fully open position relieving high pressure water, the cold leg pressure was lowered to cause the relief valve close.

This calculation was performed using RELIE2.CSL for four different opening and closing times: $1 \mathrm{~ms}, 10 \mathrm{~ms}, 20 \mathrm{~ms}$, and $50 \mathrm{~ms}$. After the initial instantaneous opening of the valve, the valve starts closing in response to low inlet pressure although the cold leg pressure stayed above the relief valve set point. As it closes the pressure rises again causing the valve reopen. The amplitude of the periodic motion (open and close) of the valve position decreases to time as it responds to pressure oscillations.

The results from the :alculation with the valve opening and closing rate based on $10 \mathrm{~ms}$ opening or closing time are shown in Fig. 1.1, 1.2, 1.3 and 1.4. The rapid oscillations of the valve position during the opening is presented in Fig. 1.1. The valve closed down to below $20 \%$ after the initial instantaneous opening. It took about $0.25 \mathrm{~s}$ to reach the stable fully open position although the opening rate was based on $10 \mathrm{~ms}$ opening time. As the cold leg pressure was lowered below the relief valve set point, the valve gradually closed. The valve was completely closed in about $100 \mathrm{~ms}$ despite the fact that the closing rate was based on $10 \mathrm{~ms}$ closing time. The valve inlet pressure is shown in Fig. 1.2. The flow rates $\left(\mathrm{lb}_{\mathrm{m}} / \mathrm{h}\right)$ at the relief valve and at the inlet of $11 / 2$ in. pipe are presented in Fig. 1.3. The periodic oscillations are clearly visible. The stable cold leg pressure and sinusoidal motion of the pressure at the inlet of the $11 / 2$ in. pipe are presented in Fig. 1.4 for the initial $0.1 \mathrm{~s}$. 


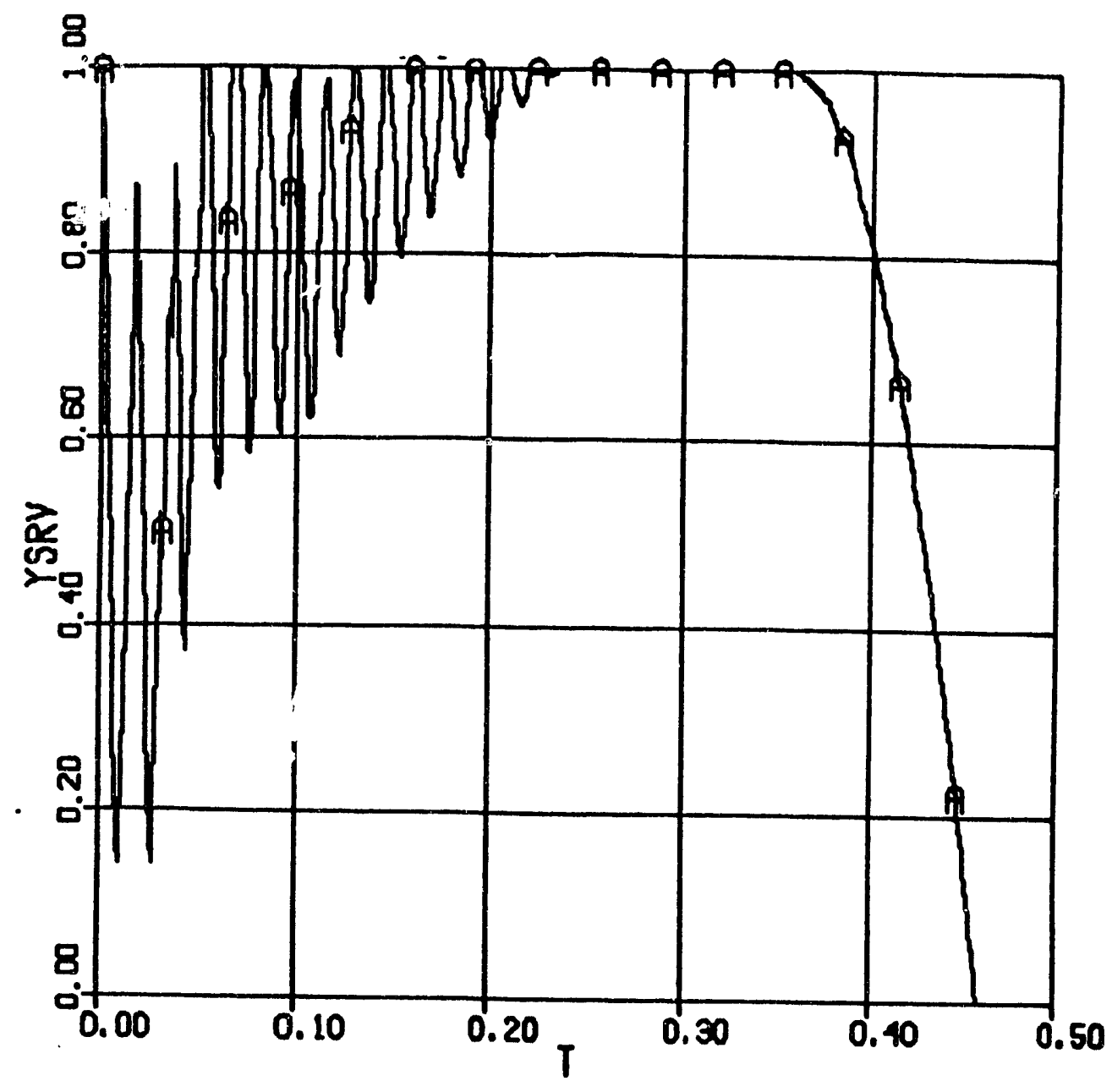

Fig. 1.1. The relief value position for a position changing rate bat 1 on $10 \mathrm{~ms}$ opening or closing time and 703 psia pressure set point - one-open-path-mociel.

$$
\begin{array}{ll}
\text { YSRV } & =\text { relief valve position } \\
\mathbf{T} & =\text { time }(s)
\end{array}
$$




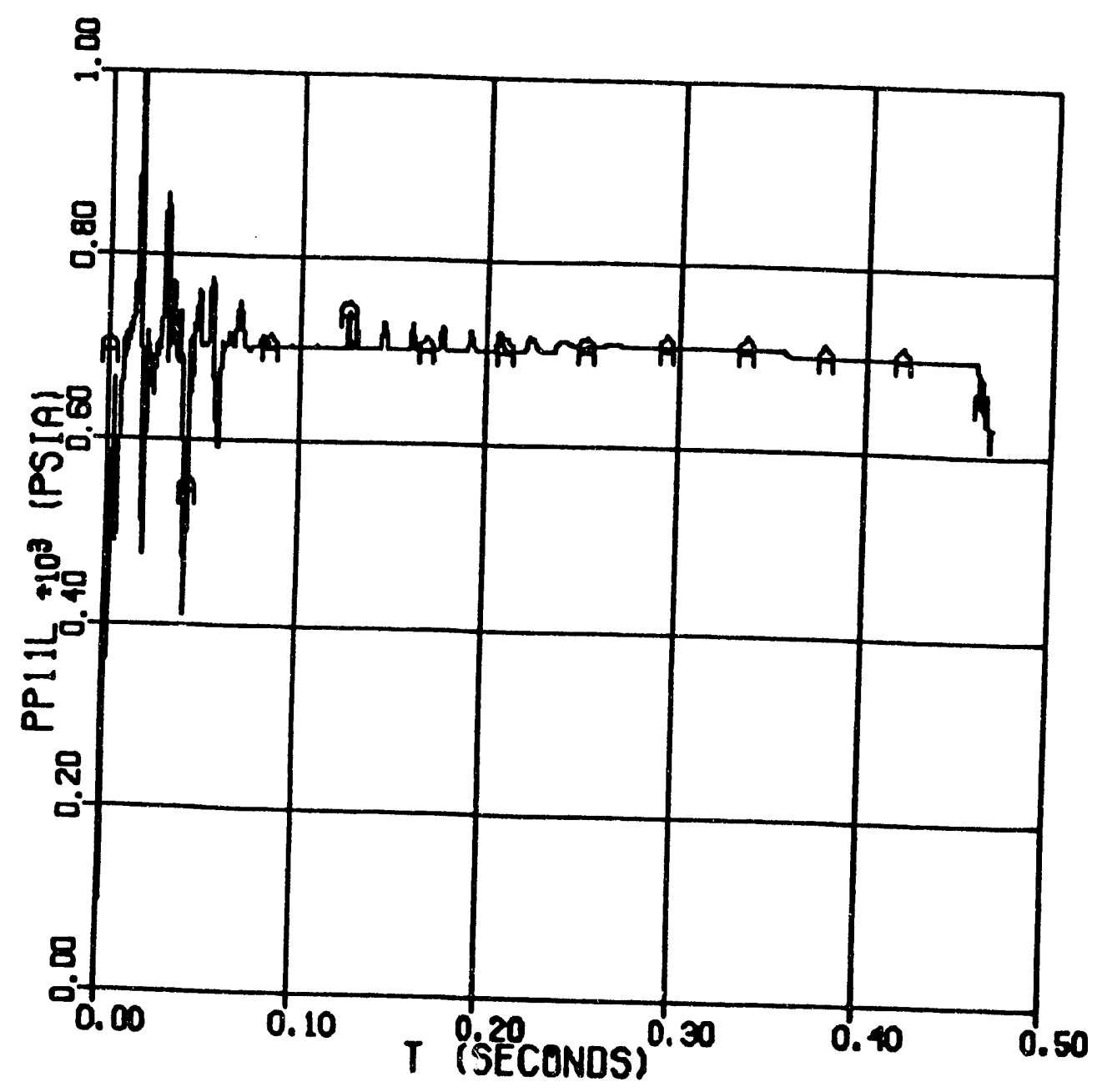

Fig. 1.2 The relief valve inlet pressure for a position changing rate based on $10 \mathrm{~ms}$ opening or closing time and 703 psia pressure set point - one-open-path-model.

$$
\begin{aligned}
& \text { PP11L }=\text { relief valve inlet pressure (psia) - curve A } \\
& \mathbf{T}=\text { time (s) }
\end{aligned}
$$




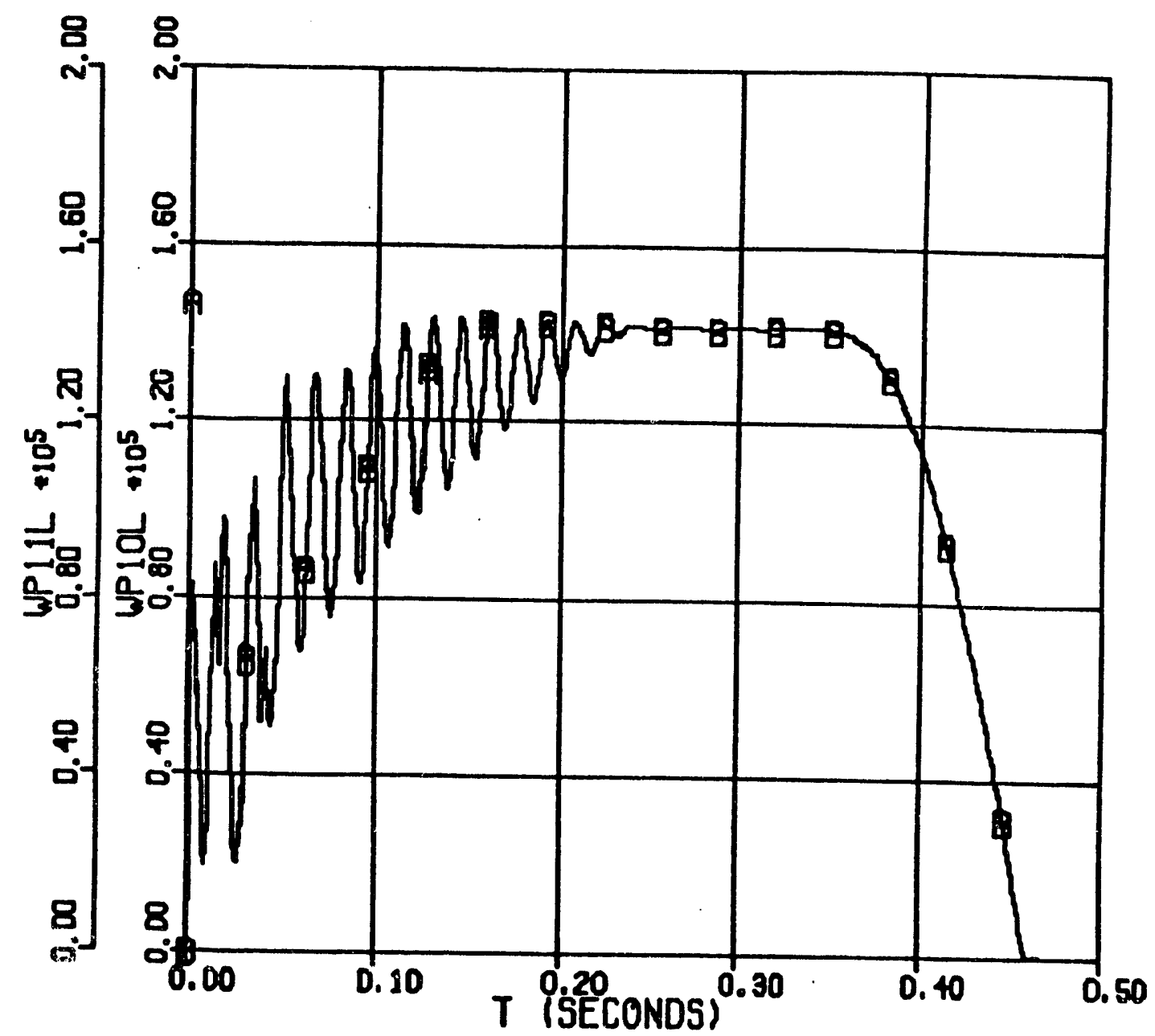

Fig. 1.3. The flow rates at the inlet of $11 / 2$ in. pipe and through the relief valve for a position changing rate based on $\mathbf{2 0} \mathrm{ms}$ opening or closing time and $\mathbf{7 0 3}$ psia pressure set point - one-open-path-model.

$$
\begin{aligned}
& \text { WP11L = relief value flow rate }(\mathrm{lb} / \mathrm{h}) \text { - curve } A \\
& \text { WP10L }=11 / 2 \text { in pipe inlet flow rate }\left(\mathrm{lb}_{\mathbf{m}} / \mathrm{h}\right) \text { - curve } B \\
& T=\text { time (s) }
\end{aligned}
$$




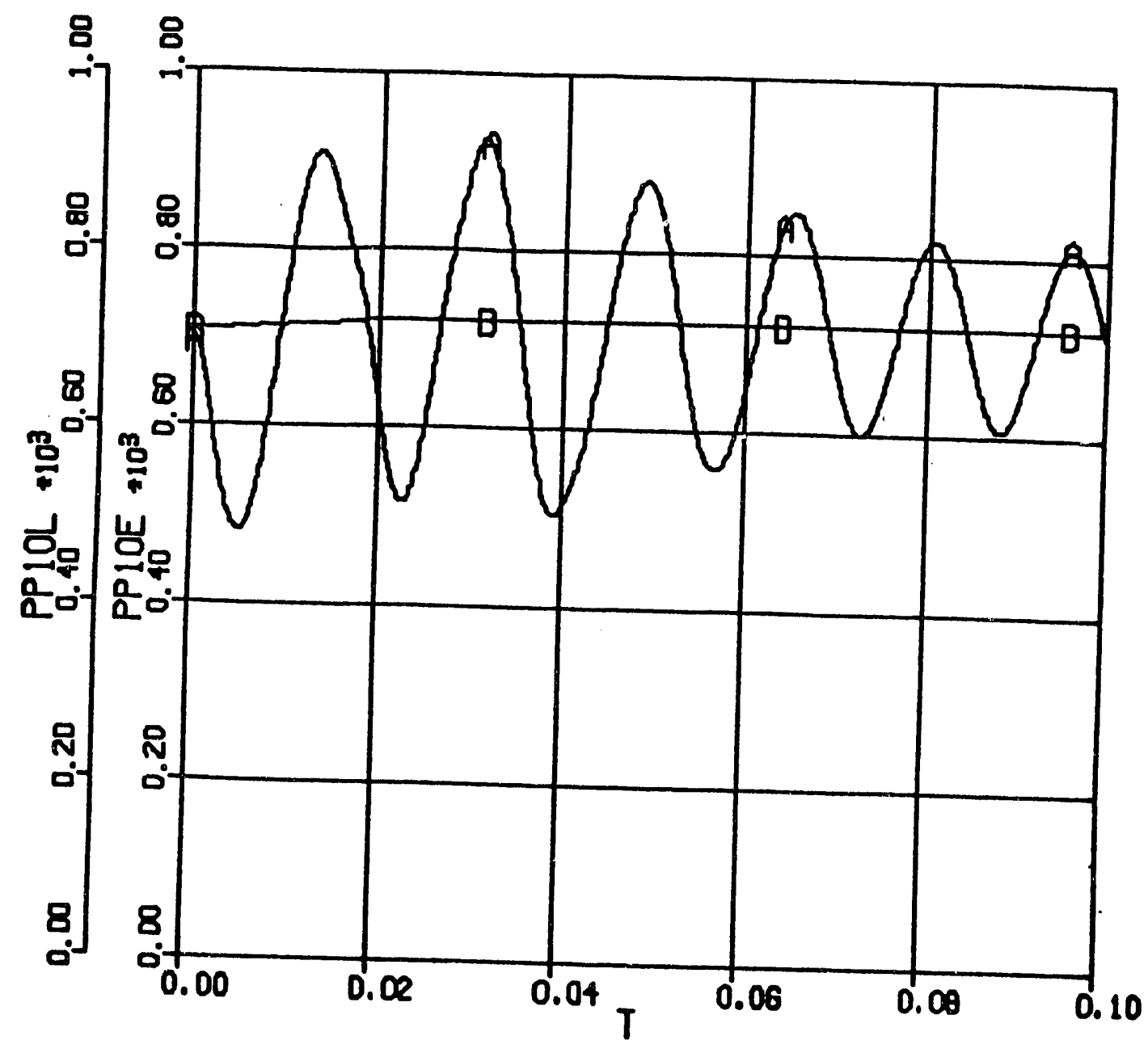

Fig. 1.4. The pressures at the inlet of $11 / 2$ in. pipe and the cold leg for a valve position changing rate based on 20 ms opening or closing time and 703 psia pressure set point - one-open-path-model.

$$
\begin{aligned}
& \text { PP10L }=11 / 2 \text { in pipe inlet pressure (psia) - curve A } \\
& \text { PP10E = cold leg pressure (psia) - curve B } \\
& \mathrm{T}=\text { time (s) }
\end{aligned}
$$


The same calculation (10 ms case) was repeated using the program RELSV2.CSL, which allows opening of both of the relief valves, for the same initial cold leg pressure profile and the same valve properties. The cold leg pressure profile used in this case is shown in Fig. 1.5 and the valve position along with the cold leg pressure profile is in Fig. 1.6. The flow rate in $\mathrm{m}^{3} / \mathrm{s}$ is shown in Fig. 1.7. The flow rate vigorously oscillates. The exit or discharge pressure of the valve is presented in Fig. 1.8. The steam-water mixture was formed at the downstream piping. Two relief paths being opened increased the time to reach the stable fully open position to $600 \mathrm{~ms}$.

The same calculation was repeated for $20 \mathrm{~ms}, 50 \mathrm{~ms}$, and $1 \mathrm{~ms}$ opening or closing time using RELIE2.CSL. The valve positions for the valve position changing rate based on $20 \mathrm{~ms}$ opening or closing time (Fig. 1.9) and for the $50 \mathrm{~ms}$ opening or closing time (Fig. 1.10) indicate similar changes to those of the $10 \mathrm{~ms}$ case. The time to stable fully open position was about $200 \mathrm{~ms}$ in all of these cases. The slow operating valve (50 ms case) reached the stable fully open position in less time than the others did. The computation was repeated using a very fast valve whose position changing rate was based on $1 \mathrm{~ms}$ opening or closing time. The valve position is presented in Fig. 1.11 for the same initial cold leg pressure profile as in the previous cases. The valve took almost twice as long (400 ms) to reach the stable fully open position as it did in the $50 \mathrm{~ms}$ case. The flow rate through the valve in $\mathrm{gpm}$ is shown in Fig. 1.12. The flow was very oscillatory until the valve became fully open. The pressure at the inlet of the relief valve, the inlet of the $11 / 2$ in. pipe and the cold leg for the first $0.1 \mathrm{~s}$ of the transient are presented in Fig. 1.13. The periodic changes of the pressure at the inlet of the $11 / 2$ in. pipe is very visible. In general, the tests performed indicate that the faster the valve was the longer it took to reach to the stable fully open position.

Two additional tests were performed using RELIE2.CSL and RELSV2.CSL to estimate how long it took for the flow to reach the steady rated flow. The relief valves were instantaneously opened at time zero and stayed stuck open in fully open position no matter what the relief valve inlet pressure was. The relief valve set point pressure was 703 psia. In both cases, it took about $0.1 \mathrm{~s}$ to reach the stable rated flow through the valves.

All of these calculations required very small time steps about $10^{-5} \mathrm{~s}$ to properly calculate rapid changes in pressure, flow rate, and valve position. The steam-water mixture was formed at the discharge of the relief yalves.

The results of the calculations performed in this category indicate that due to upstream piping the relief valve will take much longer to become fully open than the opening time implied by the quick opening rates assigned to it $(1-50 \mathrm{~ms})$. This conclusion is based on the assumption that the relief valve opens and closes at a constant rate calculated based on realistic opening and closing times of the industrial safety and relief valves. Only two pipe nodes in the inlet piping were used.

Previous to the modifications made to the MMS pipe modules PIPERS and PIPESR modules, the calculations could not be continued because negative back (valve exit or discharge) pressures were calculated although liquid water was present in that node. Normally, the liquid water will flash into steam as the pressure decreases to the vapor pressure of liquid water at that temperature. Modifications made to these modules limited 


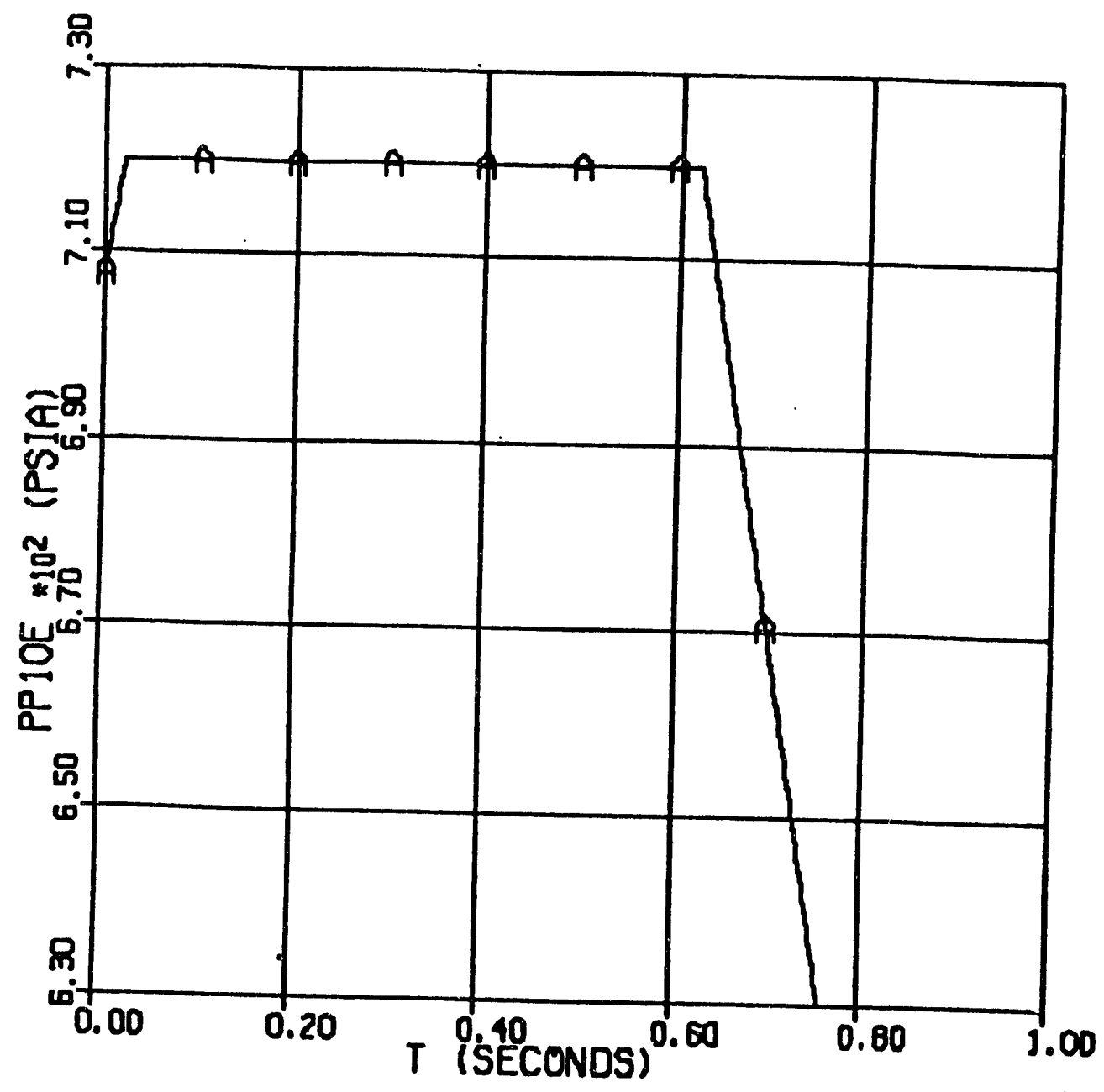

Fig. 1.5. The cold leg pressure for a position changing rate based on $10 \mathrm{~ms}$ opening or closing time and 703 psia pressure set point - two-open-path-model.

$$
\begin{array}{ll}
\text { PP10E } & =\text { cold leg pressure (psia) - curve A } \\
\mathbf{T} & =\text { time (s) }
\end{array}
$$




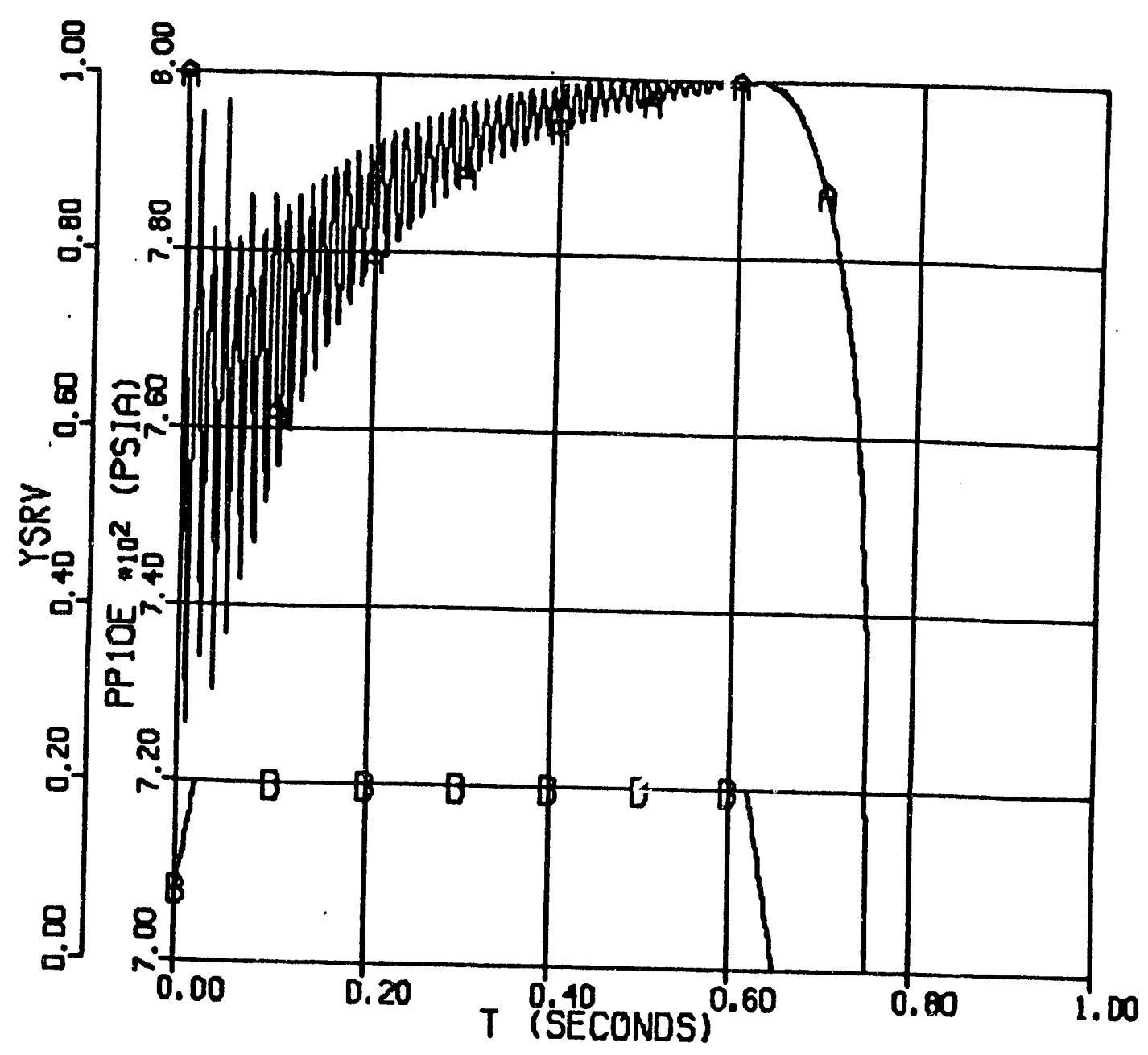

Fig. 1.6. The relief valve position and cold leg pressure for a position changing rate based on $10 \mathrm{~ms}$ opening or closing time and 703 psia pressure set point - two-open-pathmodel.

$$
\begin{array}{lll}
\text { YSRV } & =\text { relief valve position } & \text { - curve } A \\
\text { PP10E } & =\text { cold leg pressure (psia) } & \text { - curve B } \\
T & =\text { time }(s) &
\end{array}
$$




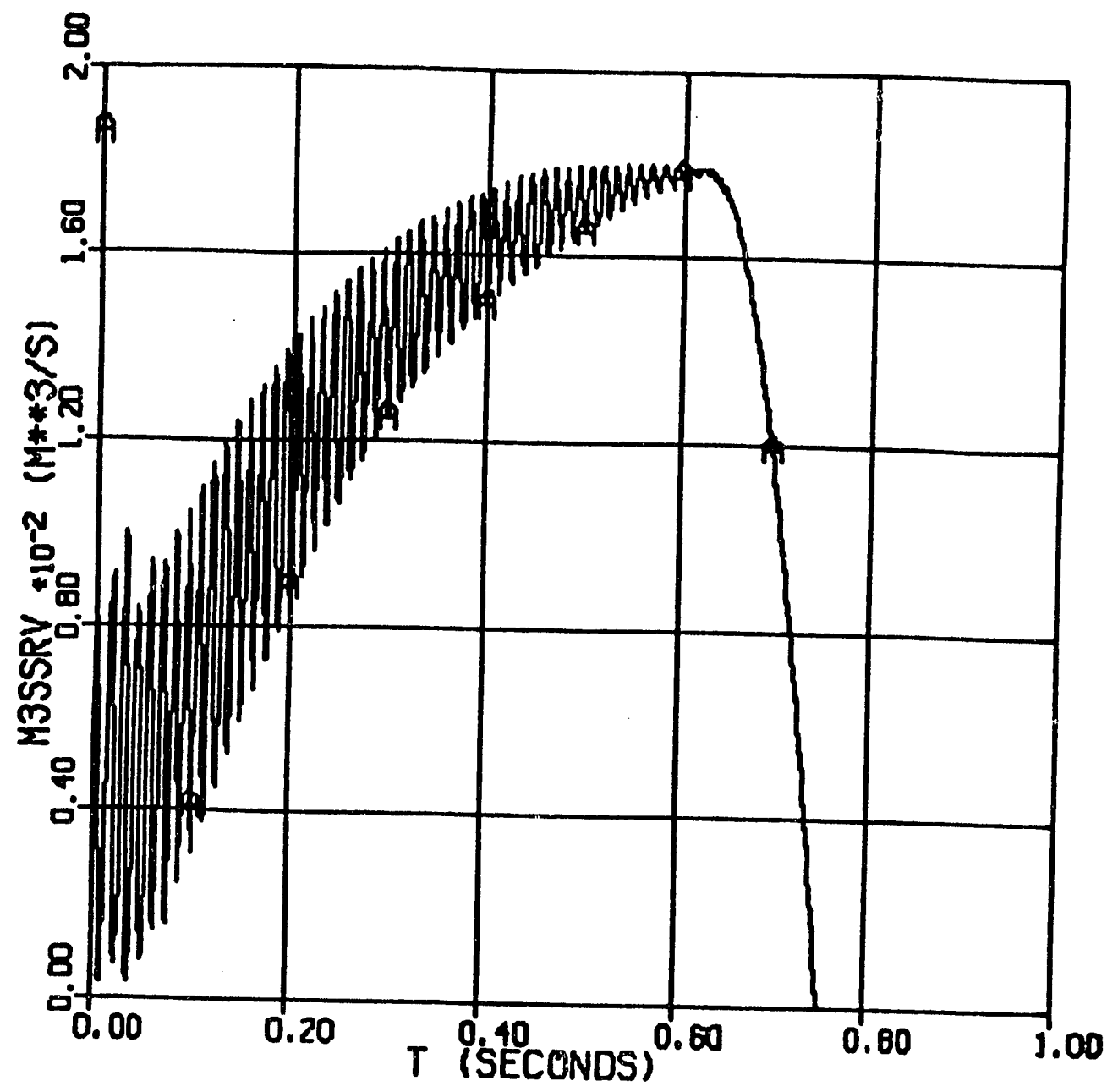

Fig. 1.7. The flow rate $\mathrm{m}^{3} / \mathrm{s}$ through the relief valve for a positin changing rate based on 10 ms opening or closing time and 703 psia pressure set point - two-open-path-model

$$
\begin{aligned}
\text { M3SSRV } & =\text { relief value flow rate }\left(\mathrm{m}^{3} / \mathrm{s}\right) \quad \text { - curve } \mathrm{A} \\
\mathbf{T} & =\text { time }(\mathrm{s})
\end{aligned}
$$




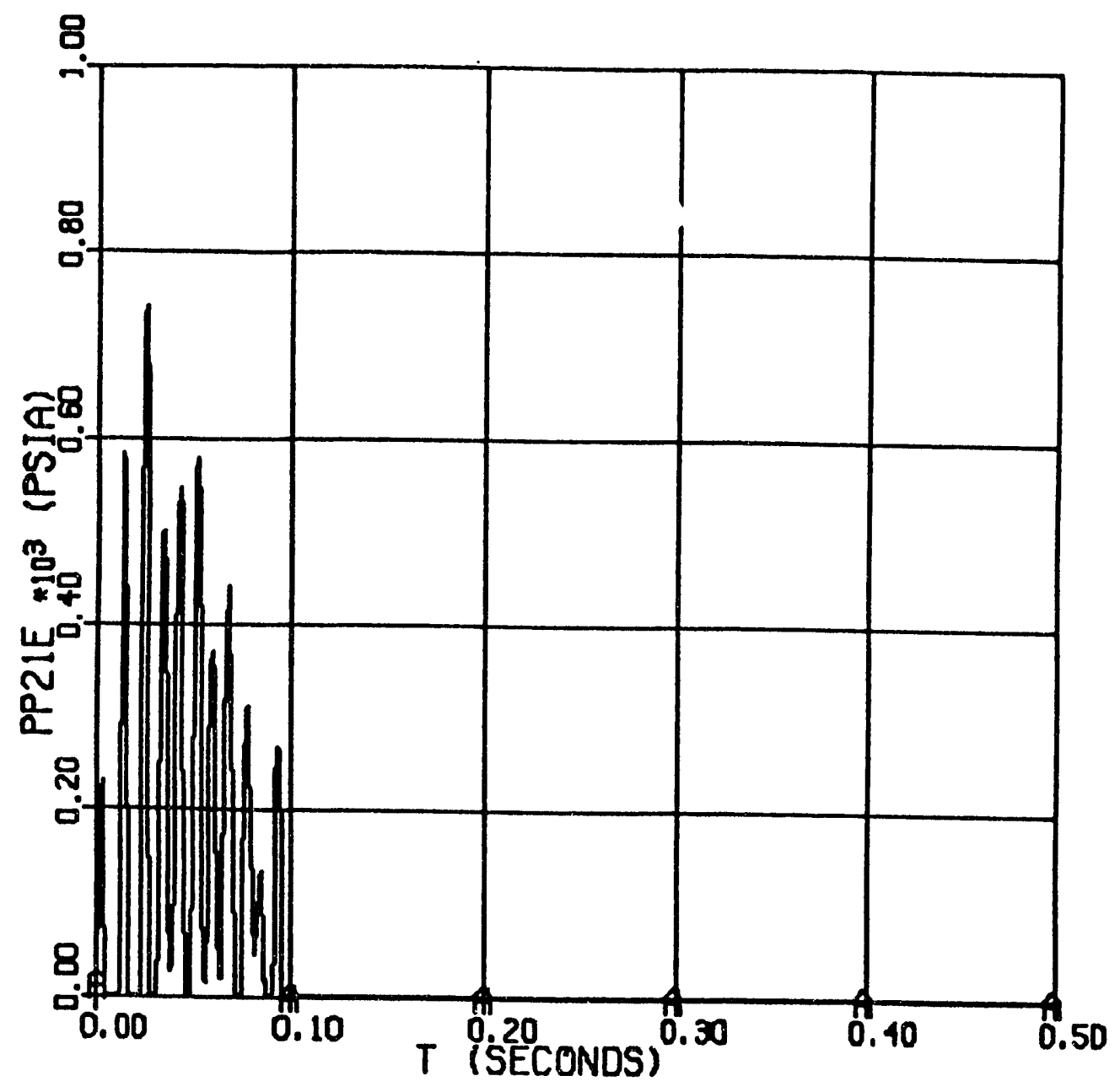

Fig. 1.8. The relief valve exit (back) pressure for a position changing rate based on $10 \mathrm{~ms}$ opening or closing time and 703 psia pressure set point - two-open-path-model

$$
\begin{aligned}
\text { PP21E } & =\text { relief valve exit pressure (psia) - curve A } \\
\mathbf{T} & =\text { time (s) }
\end{aligned}
$$




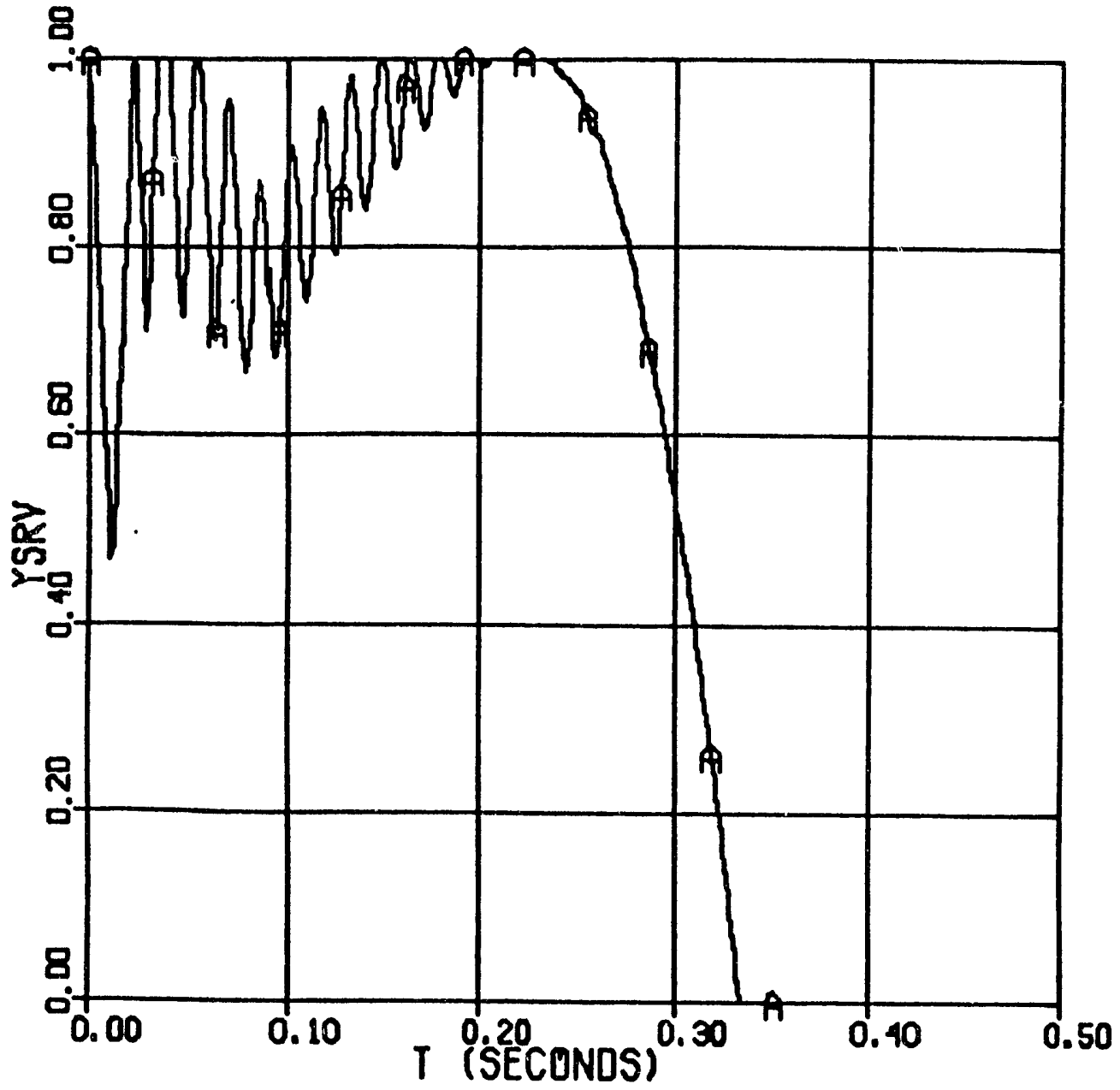

Fig. 1.9. The relief valve position for a position changing rate based on $20 \mathrm{~ms}$ opening or closing time and 703 psia pressure set point - one-open-path-model.

$$
\begin{array}{ll}
\text { YSRV } & =\text { relief valve positior } \\
\mathbf{T} & =\text { time }(s)
\end{array}
$$




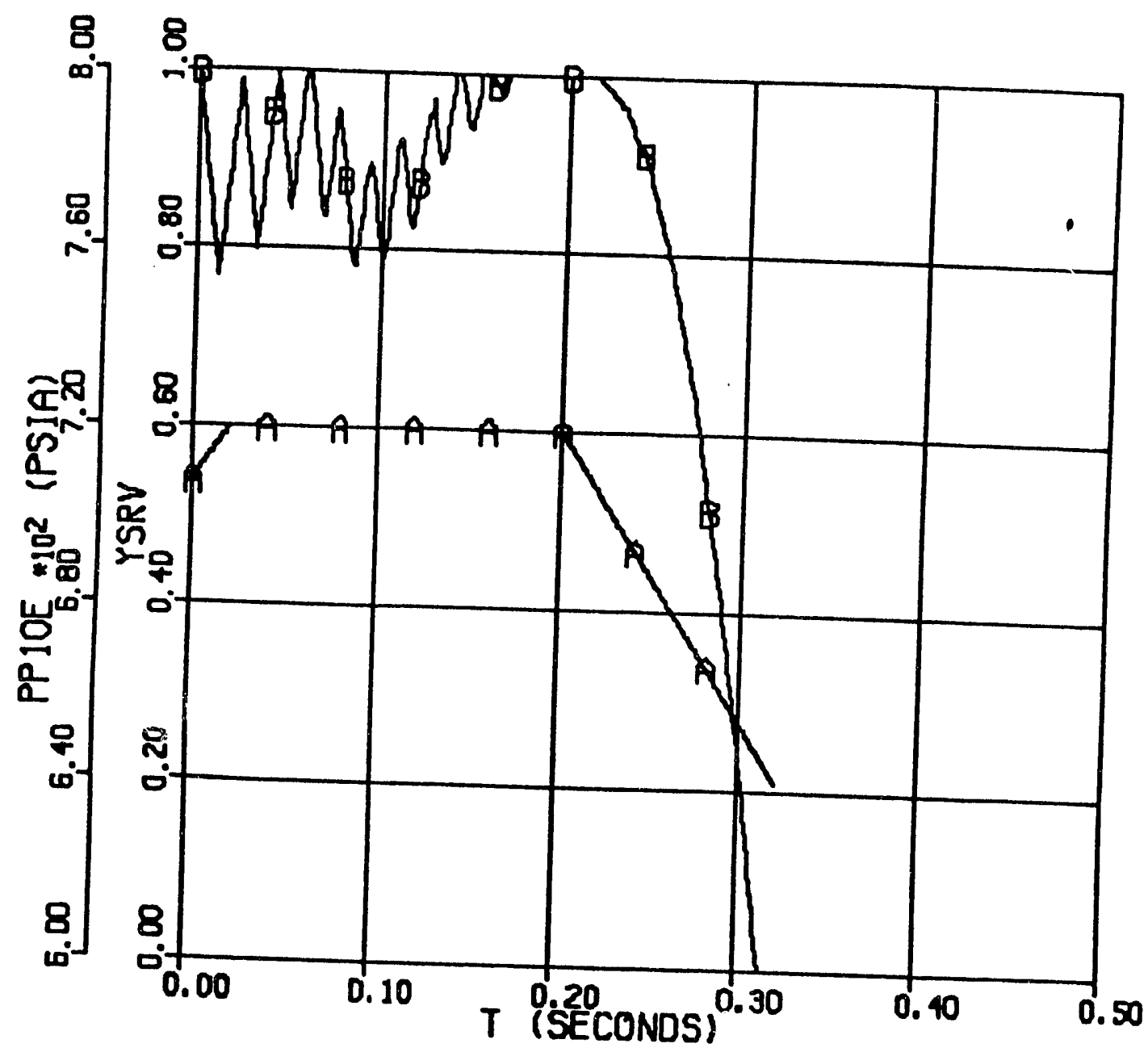

Fig. 1.10. The relief valve position and the cold leg pressure a position changing rate based on $50 \mathrm{~ms}$ opening or closing time and 703 psia pressure set point - one-open-pathmodel.

$$
\begin{array}{lll}
\text { PP10E } & =\text { cold leg pressure (psia) } & \text { - curve A } \\
\text { YSRV } & =\text { relief valve position } & \text { - curve B } \\
\mathbf{T} & =\text { time (s) } &
\end{array}
$$




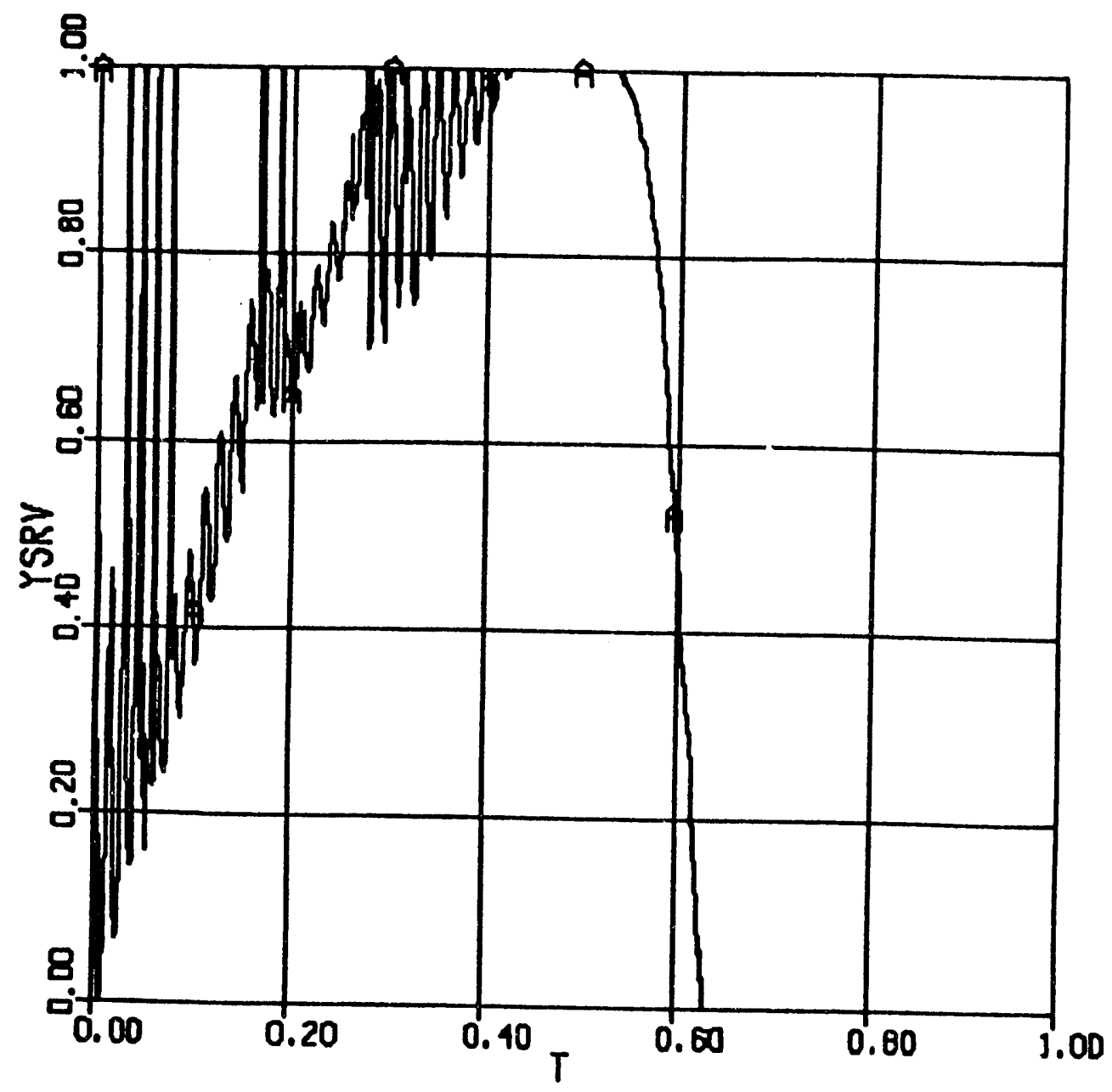

Fig. 1.11. The relief value position for a position changing rate based on $1 \mathrm{~ms}$ opening or closing time and 703 psia pressure set point - one-open-path-model.

$$
\begin{array}{ll}
\text { YSRV } & =\text { relief valve position } \\
\mathbf{T} & =\text { time (s) }
\end{array}
$$




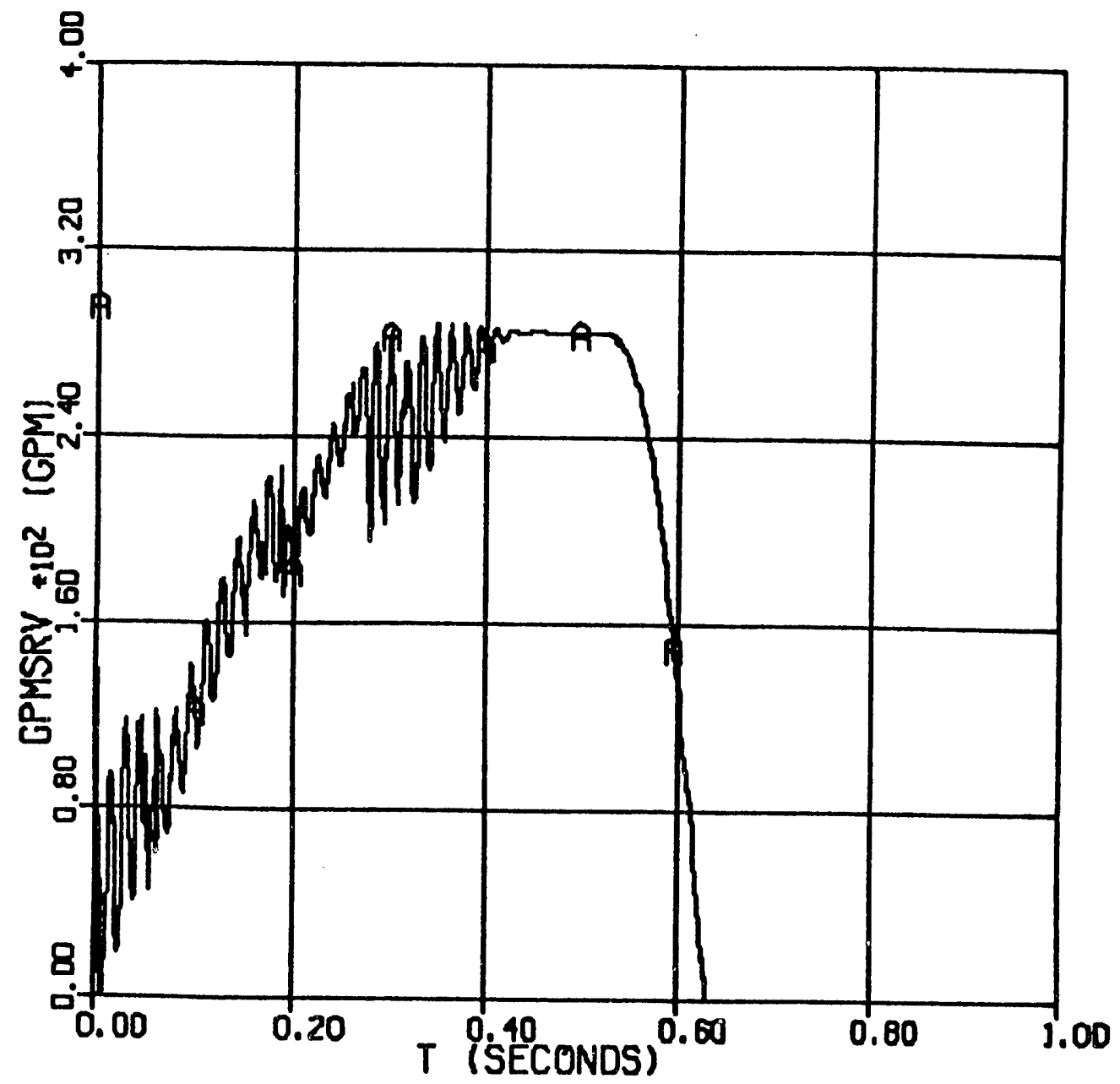

Fig. 1.12 The relief valve flow rate in grm for a position changing rate based on 1 ms opening or closing time and 703 psia pressure séi point - one-open-path-model.

$$
\begin{array}{rlr}
\text { GPMSRV } & =\text { relief valve flow rate }(\mathrm{gpm}) \quad \text { - curve B } \\
\mathbf{T} & =\text { time }(\mathrm{s})
\end{array}
$$




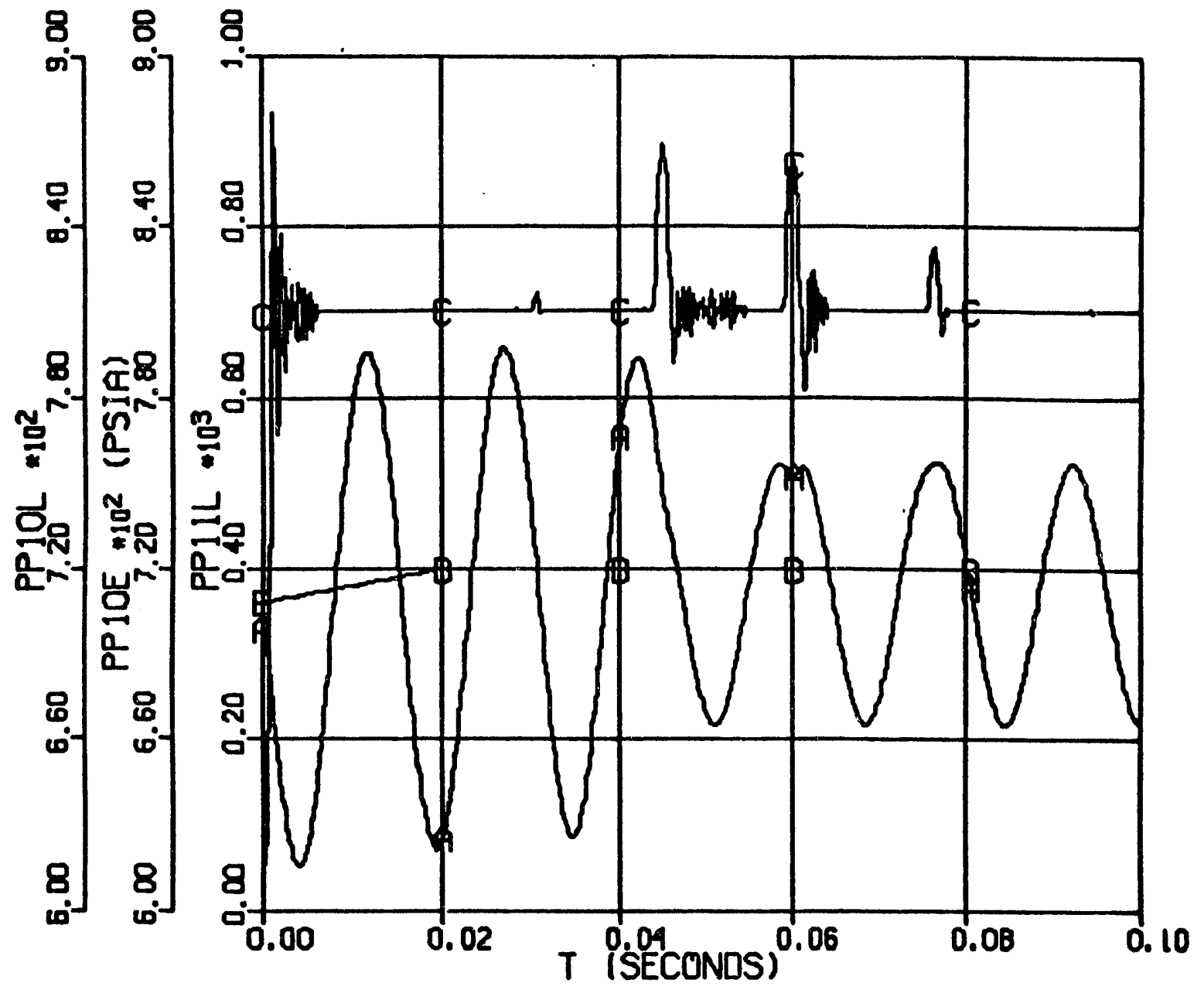

Fig. 1.13. The pressures at the inlet of the relief valve and $11 / 2$ in. pipe, and the cold leg for a position changing rate based on $1 \mathrm{~ms}$ opening or closing time and 703 psia pressure set point - one-open-path-model.

$$
\begin{aligned}
& \text { PP10L }=11 / 2 \text { in pipe inlet pressure (psia) - curve } A \\
& \text { PP10E = cold leg pressure (psia) - curve B } \\
& \text { PP11L = relief valve inlet pressure (psia) - curve C } \\
& \text { T } \quad \text { time (s) }
\end{aligned}
$$


the minimum pressure to the vapor pressure of the liquid water at temperatures near $120^{\circ} \mathrm{F}$ during the transients.

\subsubsection{Effects of Different Cold Leg Pressurization Rates on Relief Vaive Opening Time}

Effects of different pressurization rates of the primary coolant system on opening time of the relief valve was analyzed. The valve position changing rate is based on $10 \mathrm{~ms}$ opening or closing time. The one open path model (RELIE2.CS:) was used in performing the calculations. Three different initial primary coolant system pressurization rates were used. The initial cold leg pressure was 703 psia and increased to 720 psia at the rates of $80 \mathrm{psi} / \mathrm{s}$ (typical rate for runaway pressurizer pump speed transients), $1500 \mathrm{psi} / \mathrm{s}$ and $18,000 \mathrm{psi} / \mathrm{s}$.

The results of the calculation for the $80 \mathrm{psi} / \mathrm{s}$ pressurization rate are included in Fig. 2.1, and 2.2. The relief valve position and the cold leg pressure profile (boundary condition - input to the program) were shown in Fig. 2.1. After the relief valve became fully open, the cold leg pressure was dropped to 620 psia from 720 psia in $0.1 \mathrm{~s}$ in order to close the valve. The valve closed in response to the falling pressure in about $0.1 \mathrm{~s}$. The pressures at the cold leg, at the 1 1/2 in. pipe inlet, and at the relief valve inlet are indicated in Fig. 2.2. Including the valve position in the same figure allows associating the changes in the pressures with the changes in valve position. The periodic changes in the pressure is very visible at the inlet of the $11 / 2$ in. pipe. The relief valve inlet pressure displays high frequency noise as it responds to small changes in the valve position. These small high frequency fluctuations around the relief valve set point pressure continued until the valve became fully open. After the relief valve becomes fully open, the inlet pressure suddenly increased to a higher value than the set point pressure reflecting only the pressure drop due to friction and form losses in the upstream piping.

The relief valve position and the cold leg pressure profile for the $1500 \mathrm{psi} / \mathrm{s}$ pressurization rate is shown in Fig. 2.3 and for 18,000 psi/s pressurization rate in Fig. 2.4. In the last case, the cold leg pressure rose from 703 psia to 720 psia in about $0.001 \mathrm{~s}$. The three different pressurization rates and the corresponding valve opening times are listed in Table 16.

Table 16. Different cold leg pressurization rates and corresponding value opening times

\begin{tabular}{rc}
\hline $\mathrm{dP} / \mathrm{dt}$ & Valve opening time \\
$(\mathrm{psi} / \mathrm{s})$ & $(\mathrm{s})$ \\
\hline 18,000 & 0.25 \\
1,500 & 0.31 \\
$80^{\circ}$ & 0.40 \\
\hline
\end{tabular}




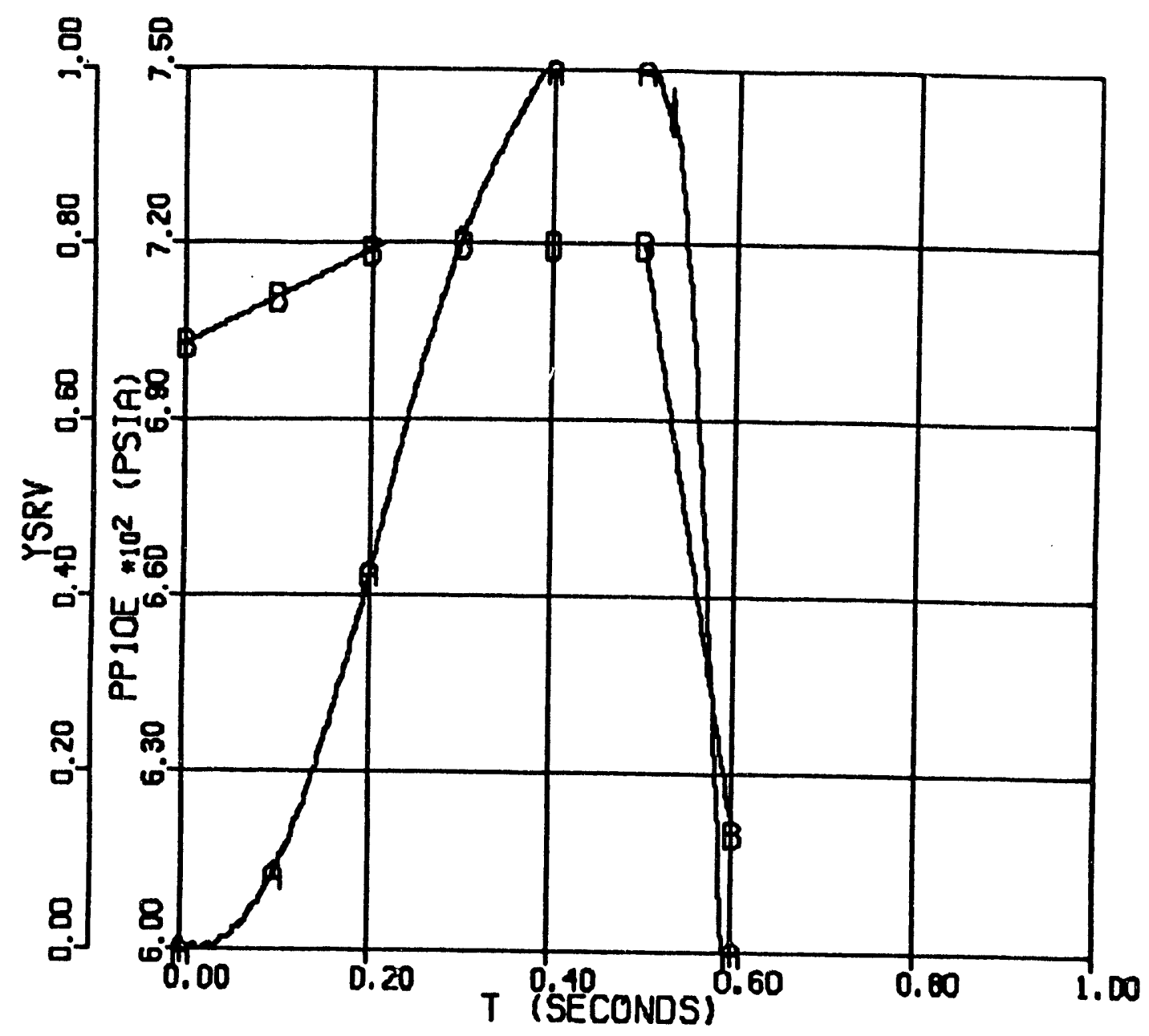

Fig. 21. The relief valve position and the cold leg pressure for a position changing rate based on $10 \mathrm{~ms}$ opening or closing time, 703 psia pressure set point and cold leg pressurization rate 80 psi/s - one-open-path-model.

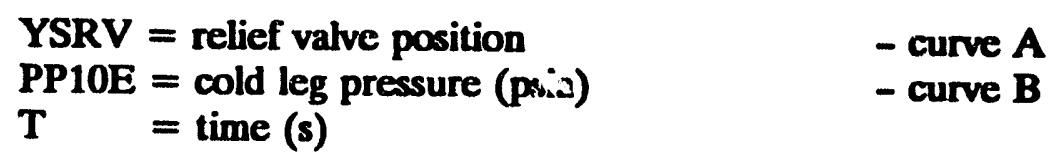




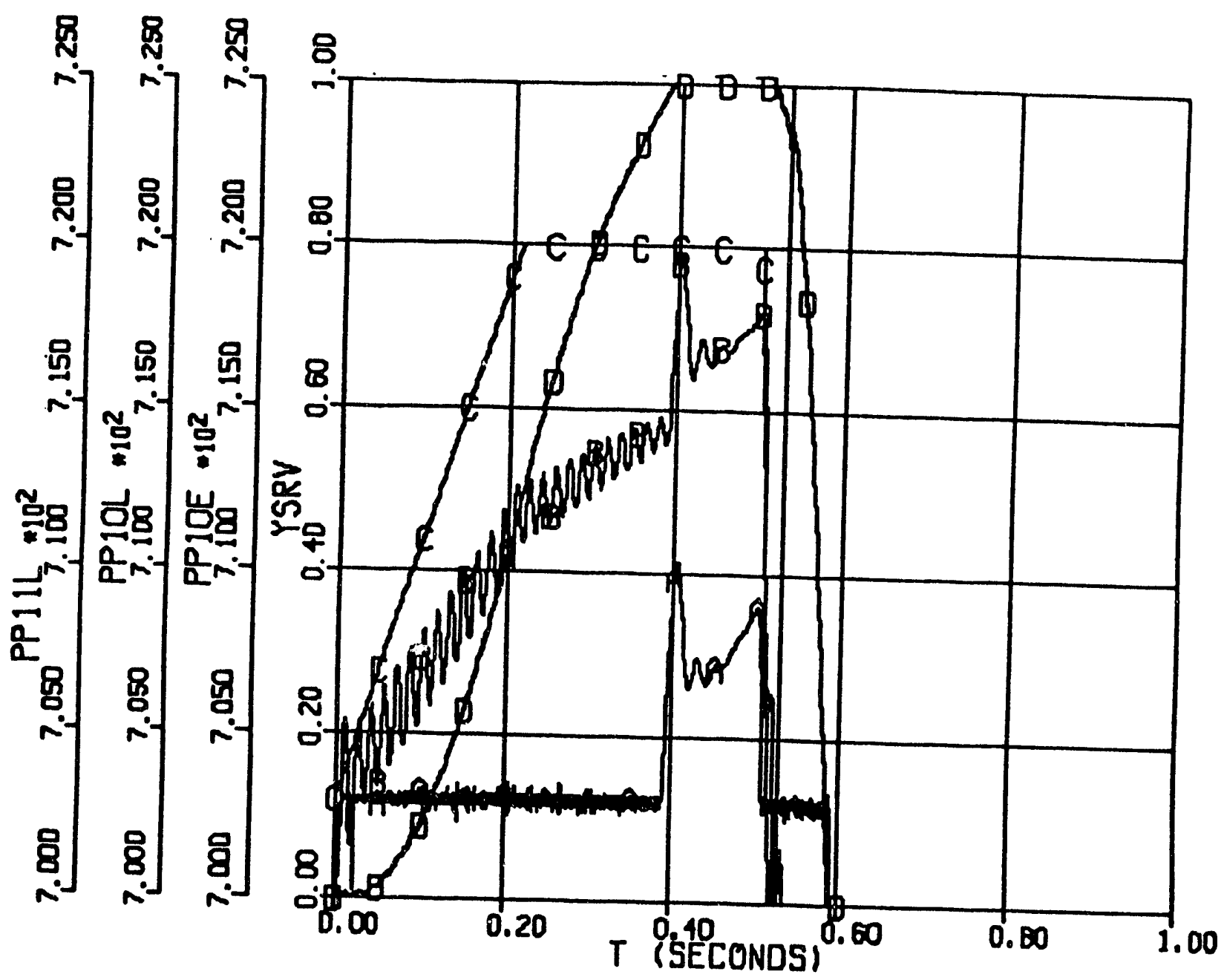

Fig. 2.2. The pressures at the inlet of relief valve and $11 / 2$ in. pipe and the cold leg for a position changing rate based on $10 \mathrm{~ms}$ opening or closing time, 703 psia pressure set point and a cold leg pressurization 80 psits - one-open-path-model.

$$
\begin{array}{ll}
\text { PP11L }=\text { relief valve inlet pressure (psia) } & \text { - curve A } \\
\text { PP10L }=11 / 2 \text { in pipe inlet pressure (psia) } & \text { - curve B } \\
\text { PP10E }=\text { cold leg pressure (psia) } & \text { - curve C } \\
\text { YSRV }=\text { value position } & \text { - curve D } \\
\text { T } \quad=\text { time (s) } &
\end{array}
$$




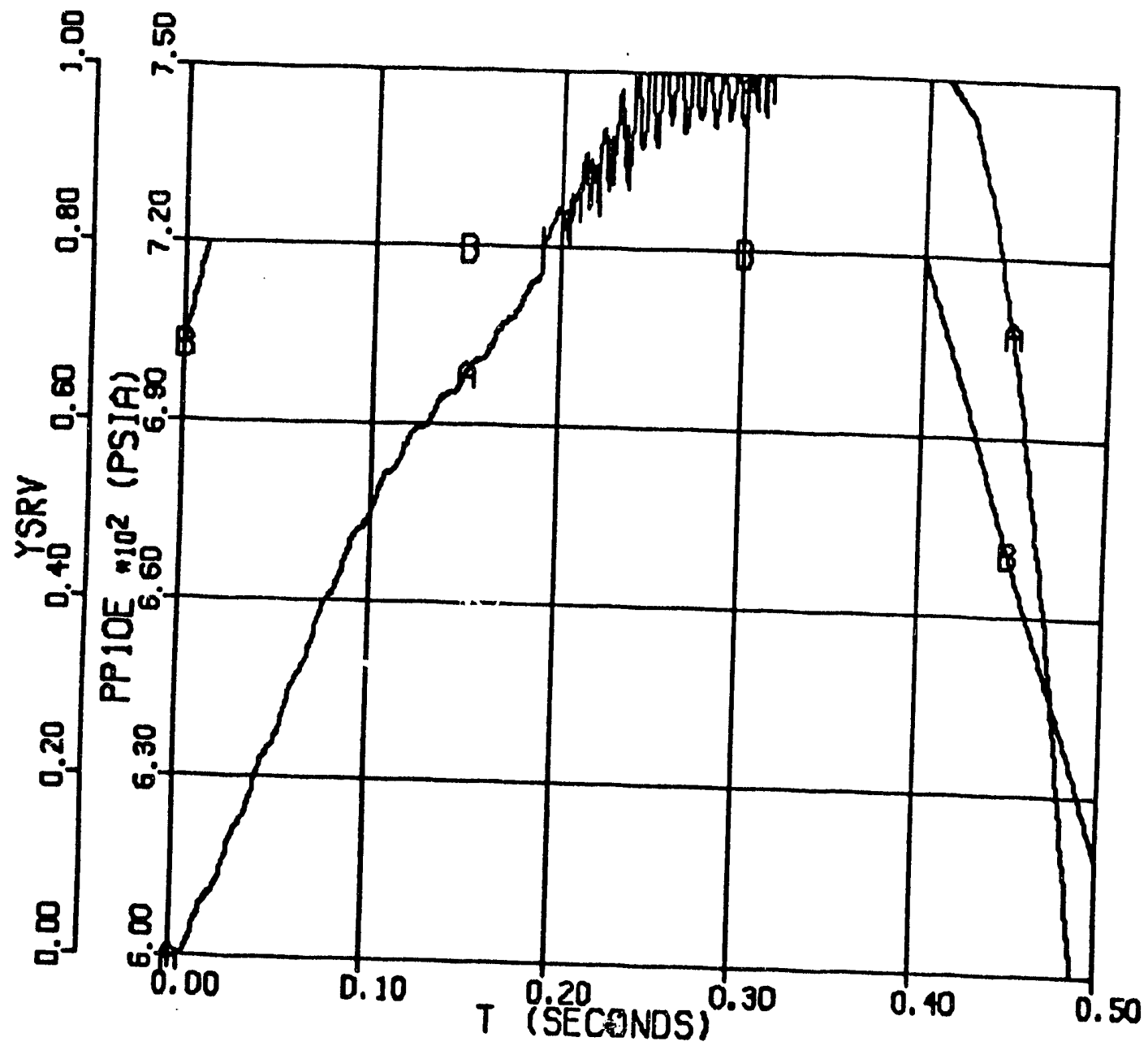

Fig. 23. The relief valve position and the cold leg pressure for a position changing rate based on $10 \mathrm{~ms}$ opening or closing time, 703 psia pressure set point and cold leg pressurization rate 1500 psi/s - one-open-path-model.

$$
\begin{array}{llr}
\text { YSRV } & =\text { relief valve position } & \text { - curve A } \\
\text { PP10E } & =\text { cold leg pressure (psia) } & \text { - curve B } \\
\text { T } & =\text { time (s) } &
\end{array}
$$




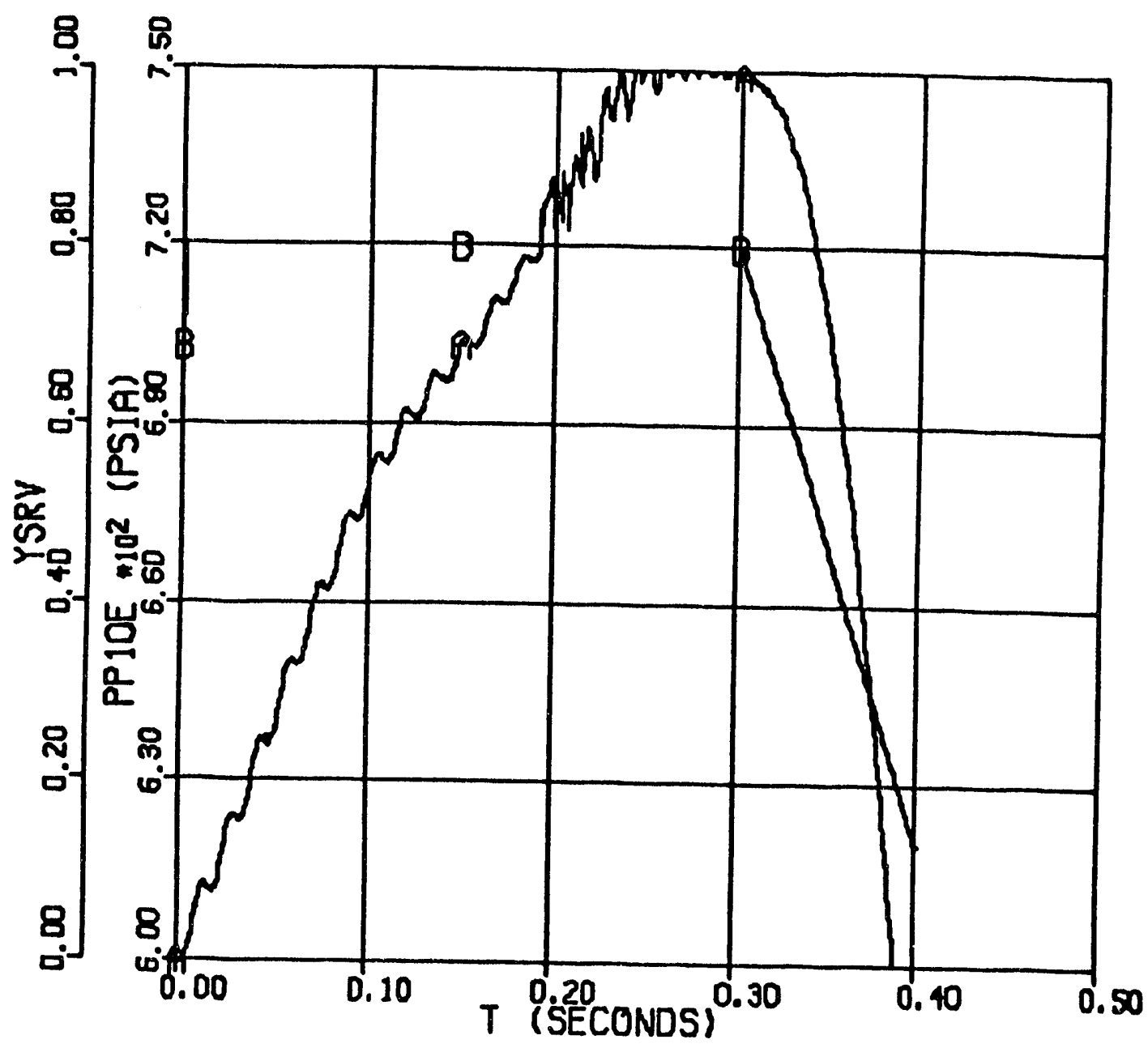

Fig. 24. The relief valve position and the cold leg pressure for a position changing rate based on $10 \mathrm{~ms}$ opening or closing time, 703 psia pressure set point and cold leg pressurization rate 18000 psi/s - one-open-path-model.

$$
\begin{array}{lll}
\text { YSRV } & =\text { relief valve position } & \text { - curve A } \\
\text { PP10E } & =\text { cold leg pressure (psia) } & \text { - curve B } \\
\text { T } & =\text { time (s) } &
\end{array}
$$


Even with very high unrealistic pressurization rates $(18,000 \mathrm{psi} / \mathrm{s})$, the relief valve opening time is larger than $10 \mathrm{~ms}$ although the valve position changing rate was based on $10 \mathrm{~ms}$ opening or closing time. These opening times are meaningful in a relative sense for the specific conditions utilized in the calculations.

Different pressurization rates, pressurization starting from an initial cold leg pressure different from 703 psia to 720 psia or to a higher pressure, and different valve position changing rates affect the opening time. Two examples are included. In the first example, the valve opening time was calculated to be about $0.18 \mathrm{~s}$ for a valve position changing rate based on $50 \mathrm{~ms}$ opening or closing time, and a $600 \mathrm{psi} / \mathrm{s}$ pressurization rate from 708 psia to 720 psia. In the second example, the valve opening time was calculated to be $0.34 \mathrm{~s}$ for a valve position changing rate based on $20 \mathrm{~ms}$ opening and closing time and a pressurization rate $1000 \mathrm{psi} / \mathrm{s}$ from 700 psia to $720 \mathrm{psia}$. Once the pressure reached to $720 \mathrm{psia}$, it was retained at that value until the valve became stable in fully open position.

The conclusion in this category is that valve opening times decrease with increasing cold leg pressurization rates for a given relief valve.

\subsection{Effects of Closed Relief Valve Path on Open Relief Valve Performance}

Effects of the closed-path on the open relief valve performance was investigated using RELVA2.CSL. The model includes a close path attached to the bifurcation point of the $11 / 2$-in. pipe, and parallel to the other $11 / 2$-in. path including the open relief valve. A test was performed to investigate whether or not the reflected pressure waves due to the close path affect stability of the open valve. The valve position changing rate was based on $10 \mathrm{~ms}$ opening or closing time. The relief valve set point pressure was 703 psia. The cold leg pressure was increased above the pressure set point to cause the valve to open. The relief valve in the closed path remained closed throughout the transient. To maximize oscillations in pressure and flow, the relief valve was assumed to instantaneously opened at time zero. After the initial instantaneous opening, the relief valve position indicated considerable periodic oscillations whose magnitude decreased in time until the relief valve became stable in fully open position in about $350 \mathrm{~ms}$. The relief valve position and the cold leg pressure profile are presented in Fig. 3.1. To close the relief valve, the cold leg pressure was reduced. The cold leg pressure profile is input to the program. The relief valve closed in about $0.1 \mathrm{~s}$. The transient was completed in about $500 \mathrm{~ms}$. (This figure may be compared to Fig. 1.1 including the results from the problem with the one open path only. The closed path was not included in the model of the Fig. 1.1.)

The flow rate (gpm) through the relief valve is shown in Fig. 3.2. The flow indicated large oscillations similar to oscillations in relief valve position. The calculated pressures at the inlet of the 1 1/2-in. pipe (bifurcation point) and the cold leg are shown in Fig. 3.3, the relief valve inlet pressure in Fig. 3.4 and the inlet pressure of the inactive closed relief valve in Fig. 3.5. The pressure at the inlet of the inactive valve reflects the changes in the pressure at the bifurcation point. 


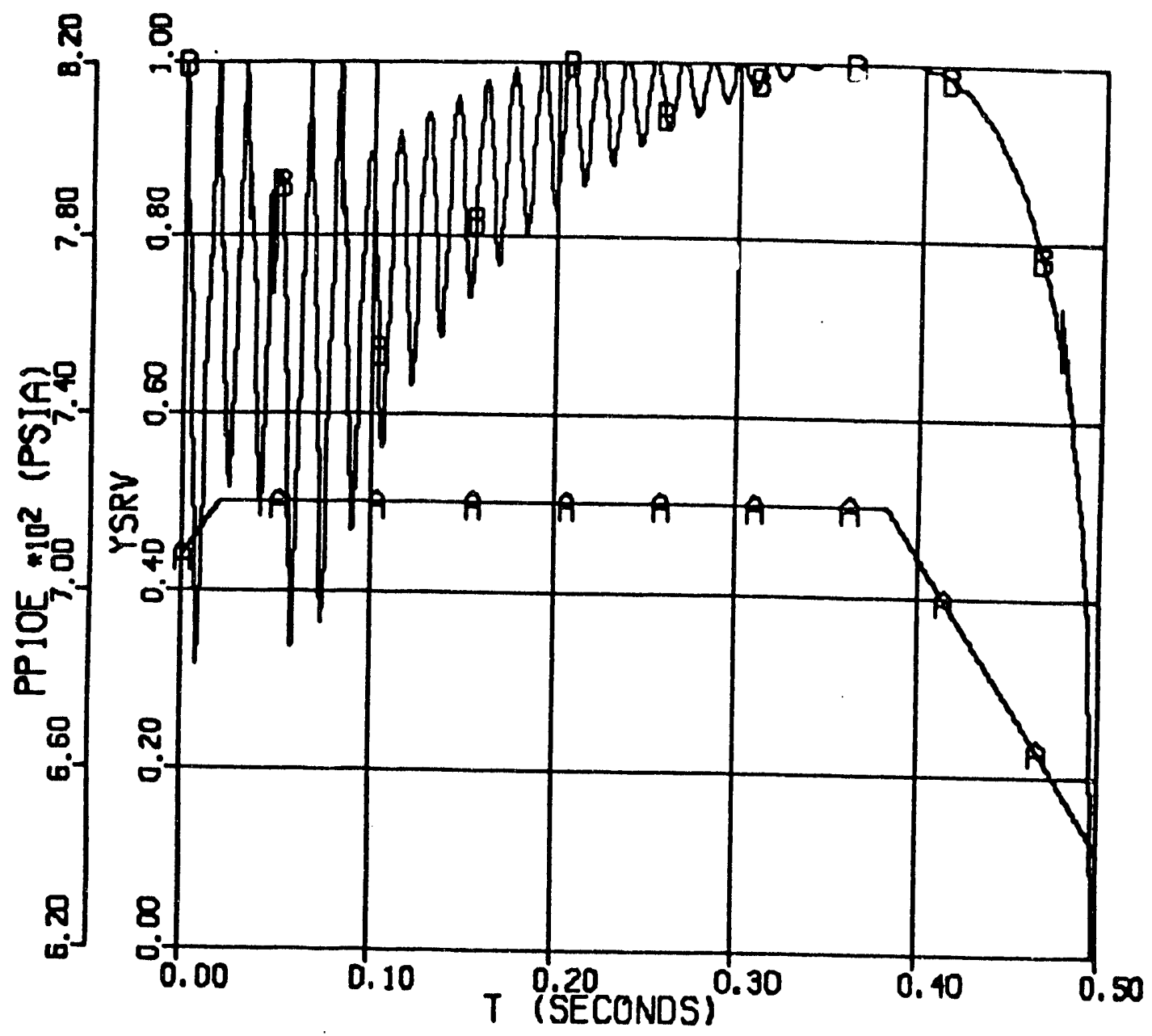

Fig. 3.1. The relief valve position and the cold leg pressure for a position changing rate based on $10 \mathrm{~ms}$ opening or closing time and 703 psia pressure set point - two-pathmodel with one path ahways closed.

$$
\begin{aligned}
& \text { PP10E = cold leg pressure (psia) } \\
& \text { YSRV = relief valve position } \\
& \text { - curve } A \\
& \mathrm{~T} \quad=\text { time (s) } \\
& \text { - curve B }
\end{aligned}
$$




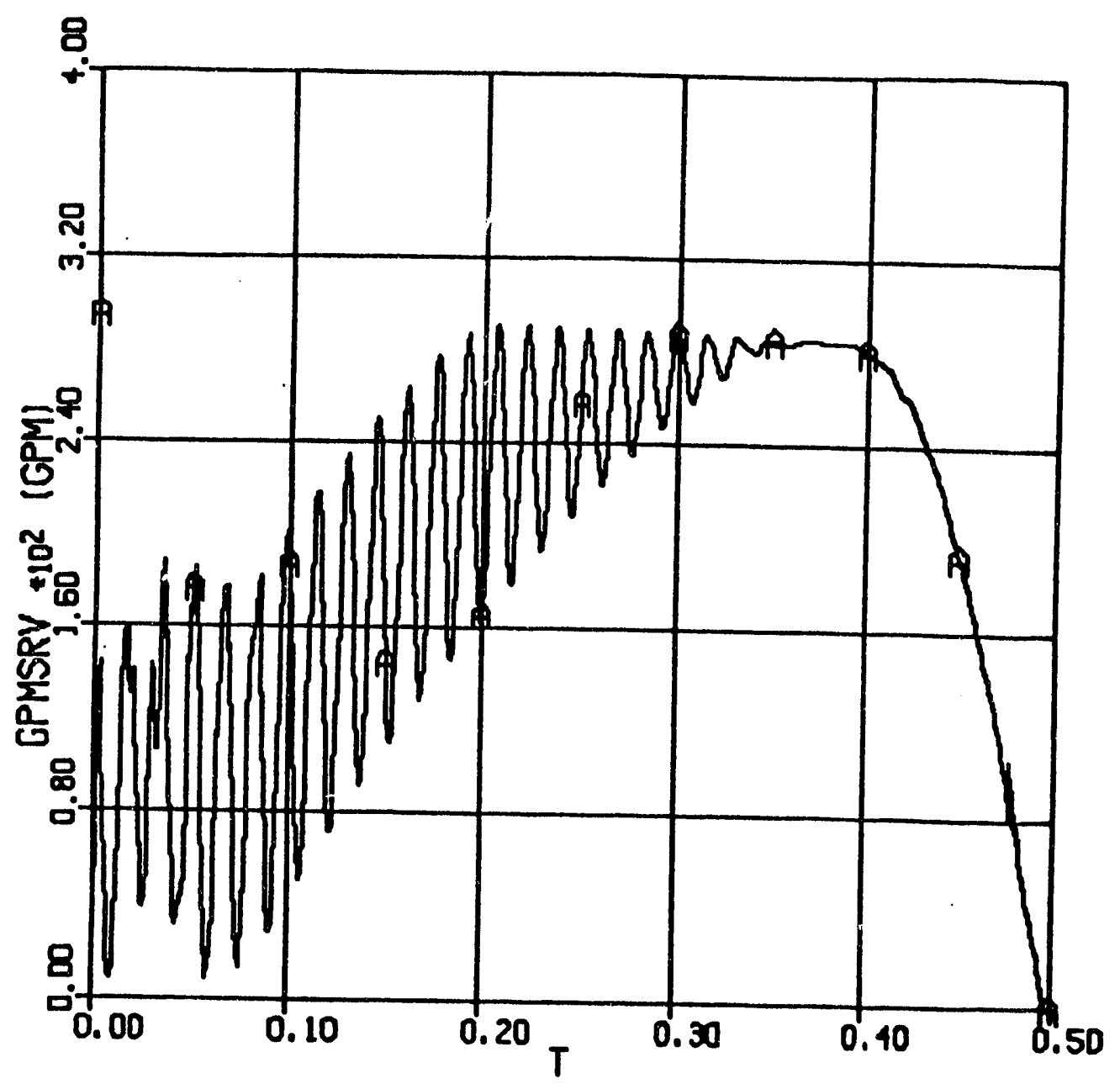

Fig. 3.2. The relief valve flow rate in gpm for a position changing rate based on 10 ms opening or closing time and 703 psia pressure set point - two-path-model with one path ahways closed.

$$
\begin{aligned}
& \text { GPMSRV = relief valve flow rate }(\mathrm{gpm}) \text { - curve } \mathrm{A} \\
& T \quad=\text { time (s) }
\end{aligned}
$$




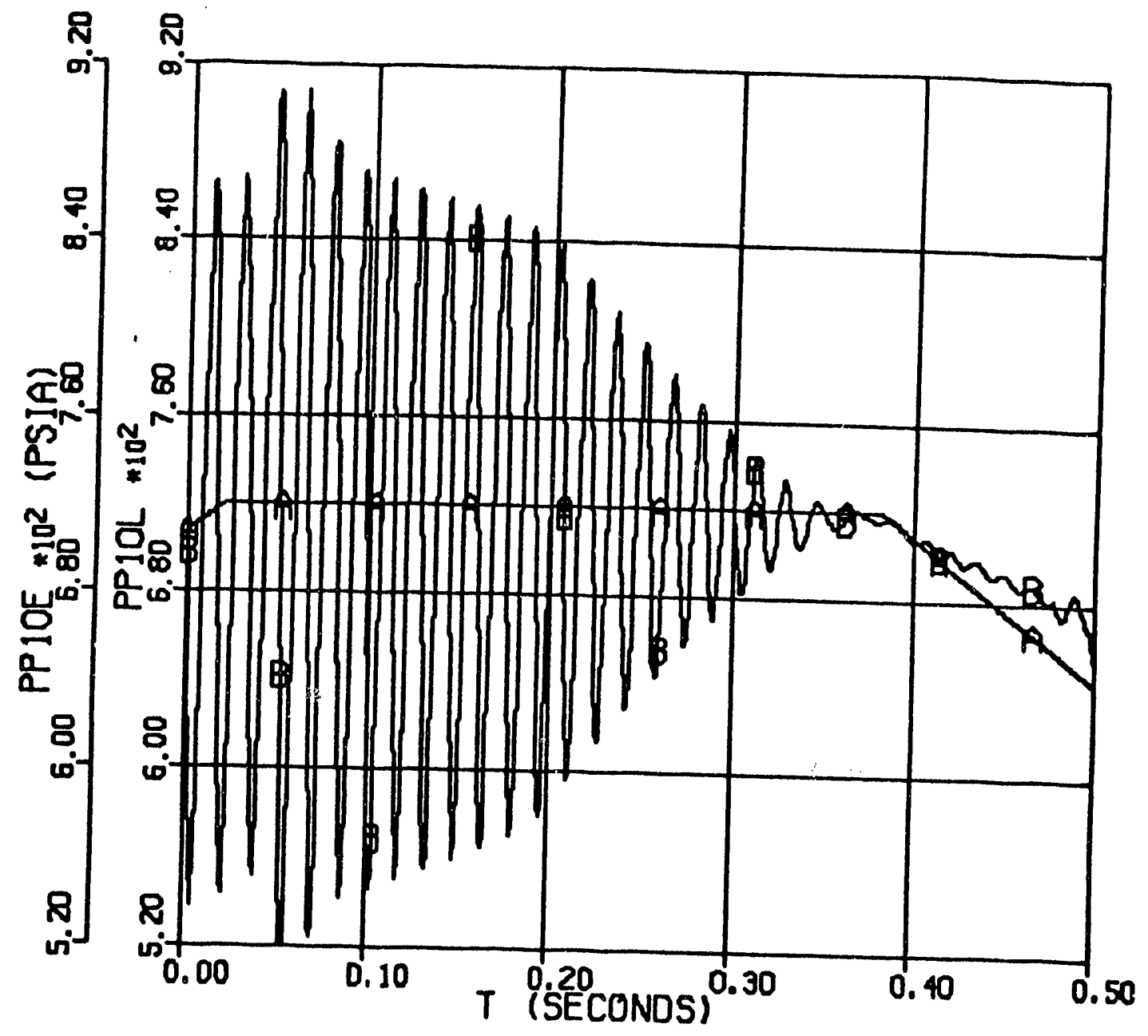

Fig. 3.3. The pressures at the cold leg and $11 / 2$ in. pipe for a position changing rate based on 10 ms opening or closing time and 703 psia pressure set point - two-path-model with one path always closed.

$$
\begin{aligned}
& \text { PP10E }=\text { cold leg pressure (psia) } \\
& \text { PP10L }=11 / 2 \text { in pipe inlet press (psia) } \\
& T \quad=\text { time (s) }
\end{aligned}
$$




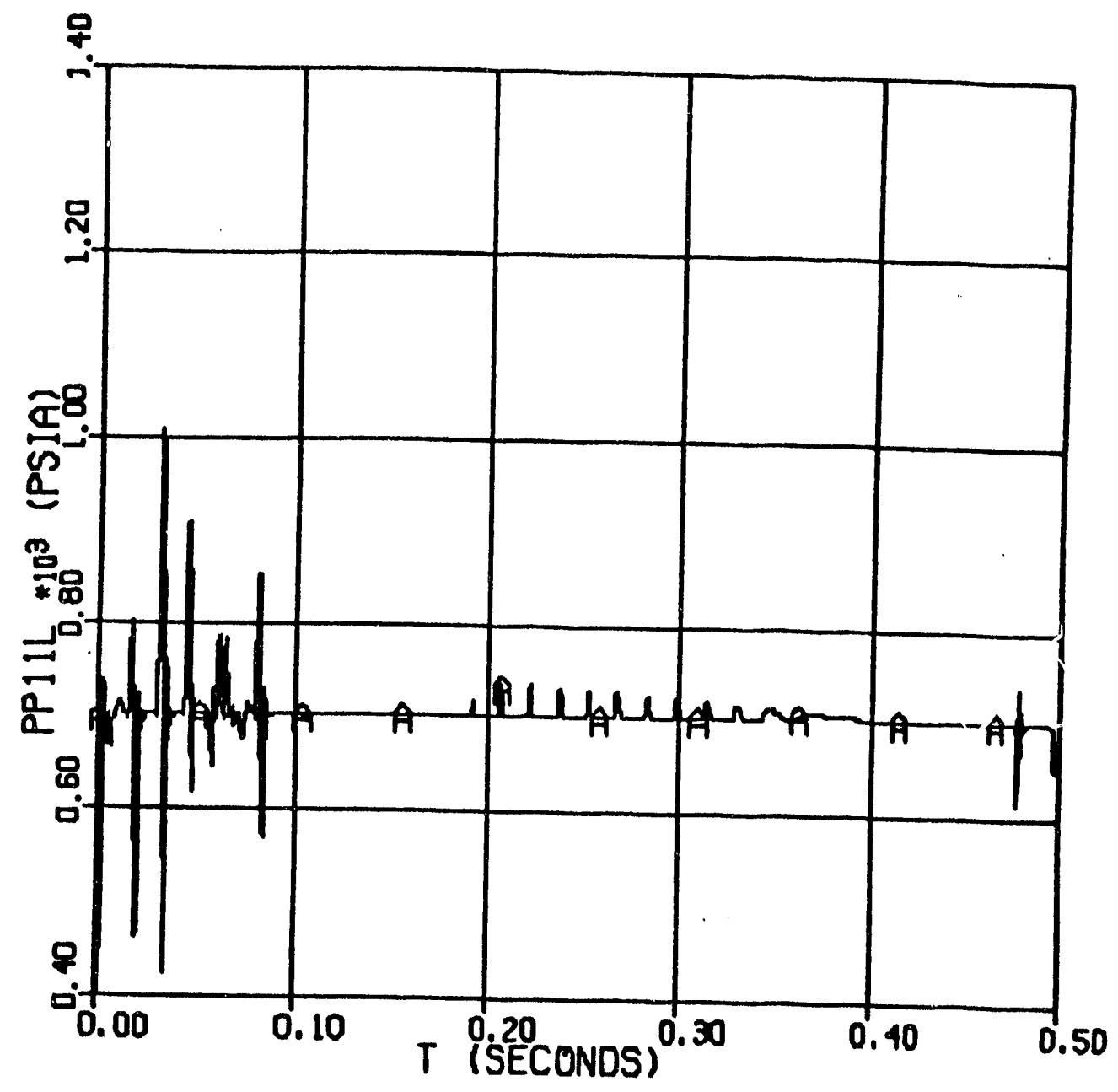

Fig. 3.4. The relief valve inlet pressure for a position changing rate based on $10 \mathrm{~ms}$ opening or closing time and 703 psia pressure set point - two-path-model with one path always closed.

$$
\begin{aligned}
& \text { PP11L }=\text { value SRV inlet pressure (psia) - curve A } \\
& \text { T }=\text { time (s) }
\end{aligned}
$$




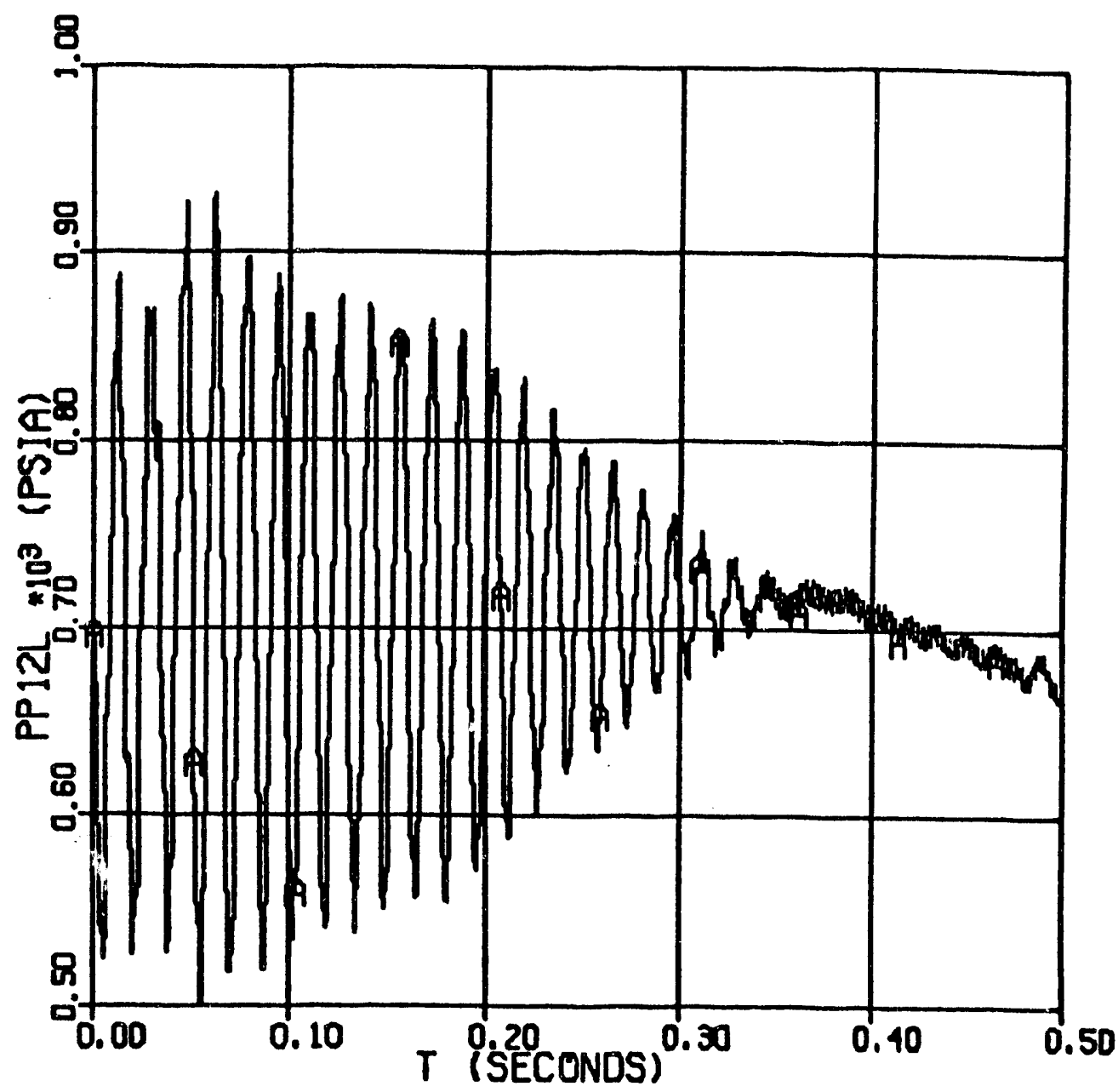

Fig. 3.5. The closed relief valve inlet pressure for a position changing rate based on $10 \mathrm{~ms}$ opening or closing time and 703 psia pressure set point - two-path-model with one path always closed.

$$
\begin{aligned}
& \text { PP12L }=\text { closed valve (SV1) inlet pressure (psia) - curve A } \\
& \mathbf{T}=\text { time (s) }
\end{aligned}
$$


The conclusion in this category is that not including the close-path in the relief valve subsystem model may not have any visible effects on the results.

\subsubsection{Effects of Different Valve Position Changing Rates and Pressure Set Points on Relief Valve Performances}

Whether or not different pressure set points and valve position changing rates negatively influence either valve's performance was analyzed using RELSV2.CSL, and RELSVL.CSL.

The RELSV2.CSL was used in the first calculation. One of the relief valves was set to open at 703 psia and assigned a valve position changing rate corresponding to $10 \mathrm{~ms}$ opening or closing time. The other had an opening set point pressure equal to 708 psia and a valve position changing rate corresponding to $20 \mathrm{~ms}$ opening or closing time. The fast opening valve reached the full open position at about $400 \mathrm{~ms}$ while the other one was open only about $80 \%$ aithough the cold leg pressure remained above 720 psia past the first $1 \mathrm{~ms}$ of the transient. Its maximum opening reached $94.7 \%$ at about $800 \mathrm{~ms}$. The transient was not run long enough to allow it to become $100 \%$ open. The equal percentage characteristics were assumed for both of the valves conservatively. Due to differences between two valves, no concernable degradation of either valve's performance was observed other than the slow valve not being fully open during $1.5 \mathrm{~s}$. This is not a concern because the flow through these two valves is larger than the flow through only one open valve under similar conditions.

The results of this transient are summarized in Figs. 4.1 through 4.6. The valve positions are shown in Fig. 4.1. The pressures at the cold leg, at the inlet of $11 / 2$ in. pipe, and at the relief valve inlets are shown in Fig. 4.2. The valve positions are also presented in the same figure so that the changes in the pressures can be correlated with the changes in valve positions. This figure provides a portrait of rapid oscillations in the pressures along with the changes in valve positions although it is difficult to isolate each curve visually. It provides a view of complex interactions taking place in a short time. The cold leg pressure is the boundary condition and an input to the program. The maximum cold leg pressure was set not to exceed 720 psia. The relief valve inlet pressure increased as high as 736 psia and decreased as low as 622 psia due to oscillations during the transient. The minimum cold leg pressure was 651 psia during closure of the valves. For better viewing of the changes during the initial opening of the valves, the inlet pressures and valve positions are presented in Fig. 4.3 for the first $0.1 \mathrm{~s}$. Although the $11 / 2$ in. lines are identical, the relief valve inlet pressures remained around their set point pressures 703 psia and 708 psia until they became stable in fully open position. Because the valve responds to pressure changes below and above the set point pressure by closing and opening respectively, it tends to regulate the pressure about the pressure set point until the valve becomes fully open.

Figure 4.4 illustrates the periodic changes in the relief valve back pressures. Although different, periodic movement of the back pressures of the relief valves in general overlap (curve D). Curve C, overlapping curve $D$, is not distinguishable within the resolution of the figure. The periodic changes of the pressures include rigorous small scale fluctuations. The valve inlet pressures are also provided in the same figure in order to provide a better view 


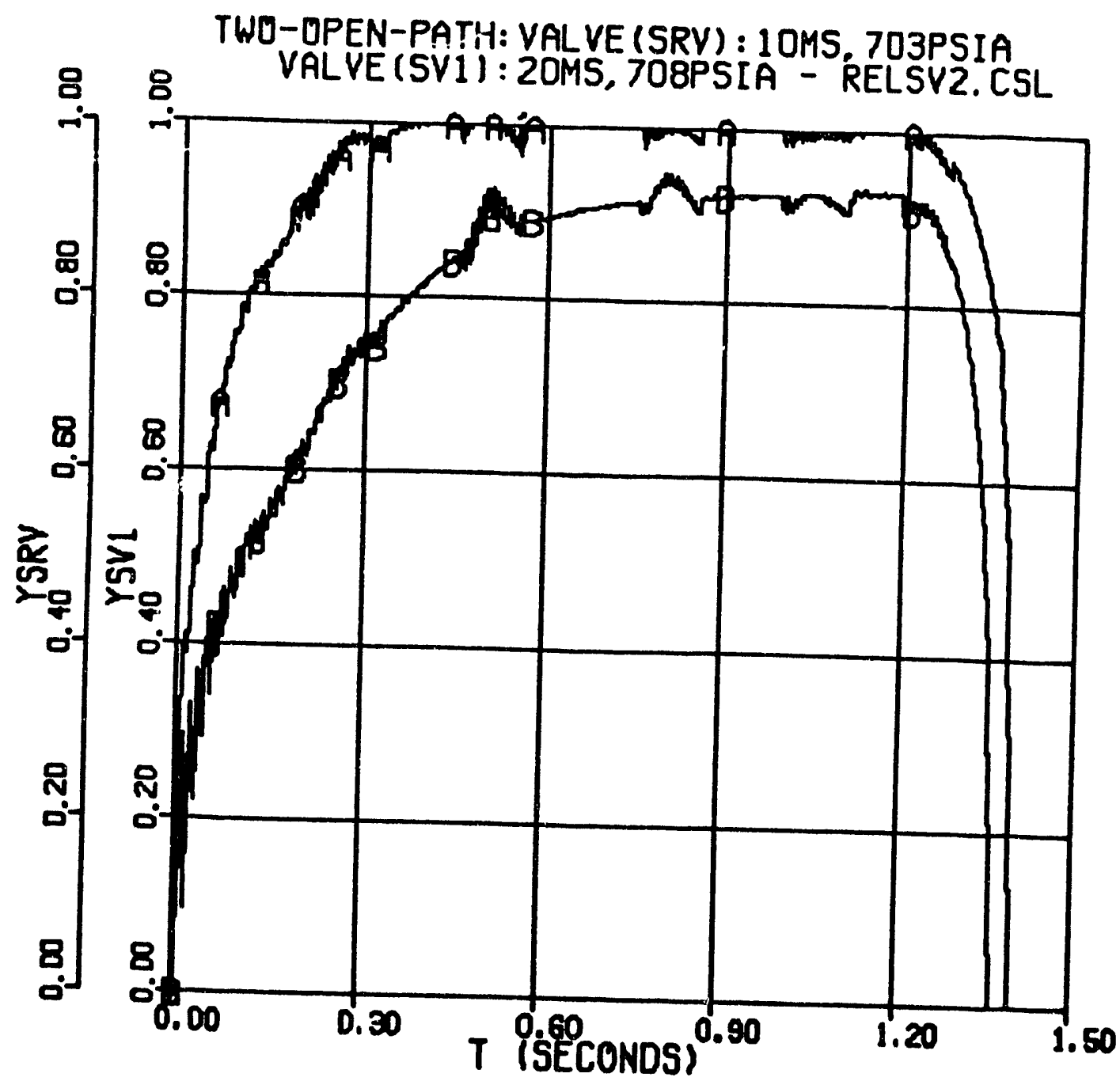

Fig. 4.1. The relief value positions for position changing rates based on 10 and $20 \mathrm{~ms}$ opening and closing times and 703 and 708 psia pressure set points respectively two-openpath-model.

$$
\begin{array}{lll}
\text { YSRV } & =\text { relief valve (SRV) position } & \text { - curve A } \\
\text { YSV1 } & =\text { relief valve (SV1) position } & \text { - curve B } \\
\mathbf{T} & =8 &
\end{array}
$$




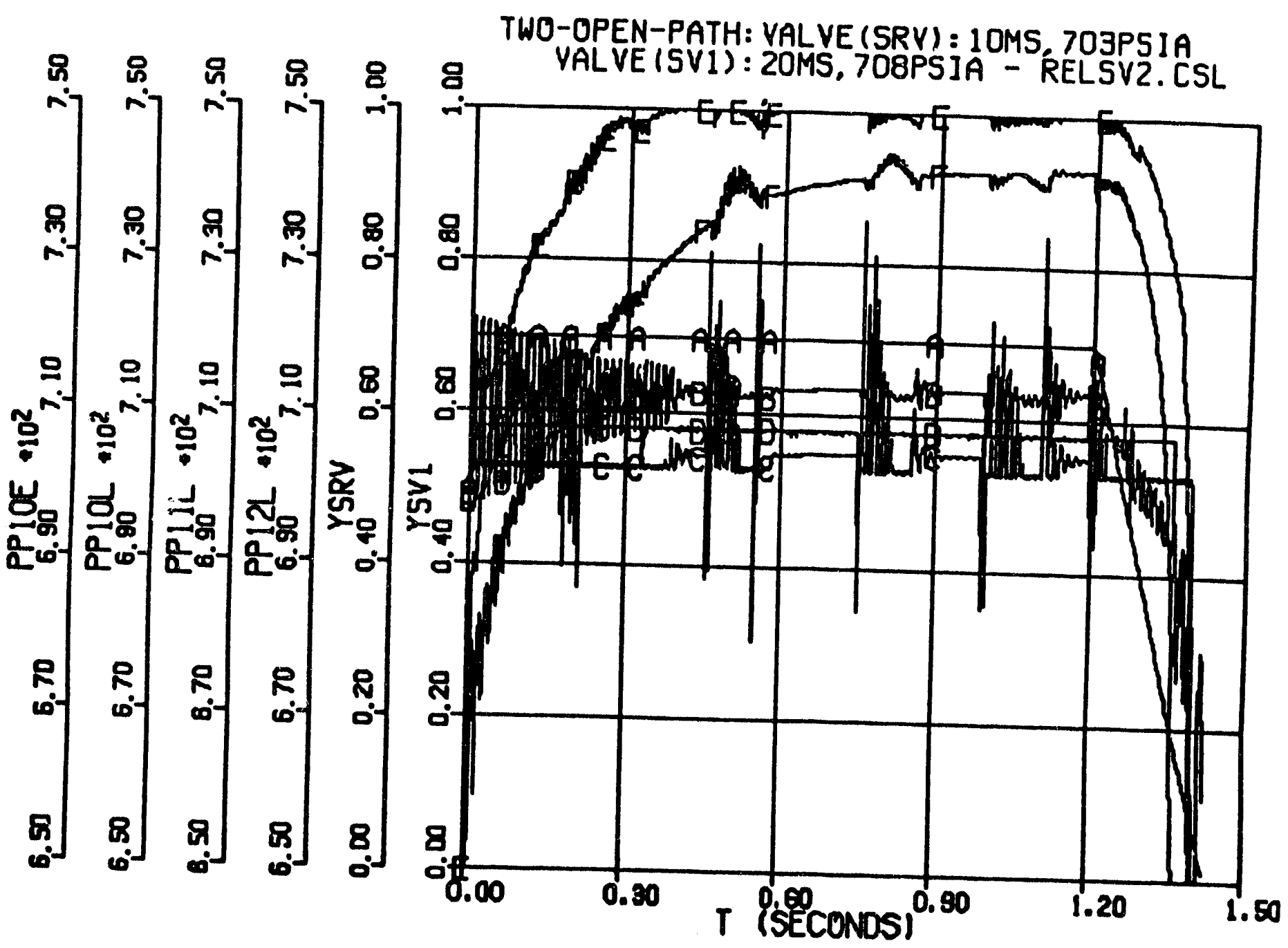

Fig. 4.2 The pressures at the cold $\mathrm{leg}$, at the inlet of $11 / 2$ in. pipe, and the inlet of the valves, and relief valve positions for position changing rates based on 10 and $20 \mathrm{~ms}$ opening and closing times and 703 and 708 psia pressure set points respectively - two-openpath-model.

$$
\begin{array}{ll}
\text { PP10E }=\text { cold leg pressure (psia) } & \text { - curve A } \\
\text { PP10L = } 11 / 2 \text { in. pipe inlet pressure (psia) } & \text { - curve B } \\
\text { PP11L = relief valve (SRV) inlet pressure (psia) } & \text { - curve C } \\
\text { PP12L = relief valve (SV1) inlet pressure (psia) } & \text { - curve D } \\
\text { YSRV = relief valve (SRV) position } & \text { - curve E } \\
\text { YSV1 = relief valve (SV1) position } & \text { - curve F } \\
\text { T }=\text { time (s) } &
\end{array}
$$




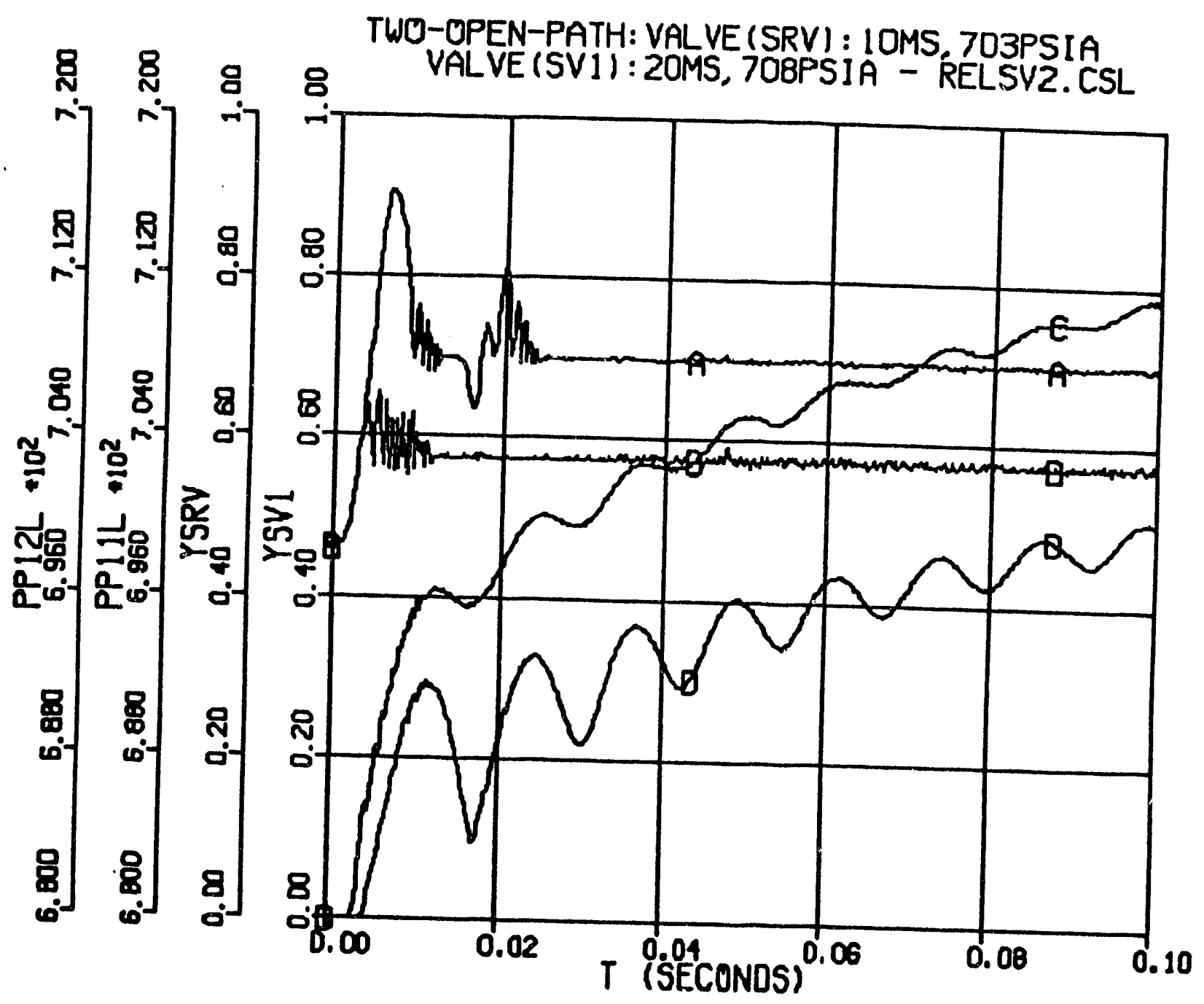

Fig. 4.3. The pressures at the inlet of the valves and relief valve positions for position changing rates based on 10 and $20 \mathrm{~ms}$ opening and closing times and 703 and 708 psia pressure set points respectively during the first 0.1 s - two-open-path-model.

$$
\begin{aligned}
& \text { PP12L = closed valve SV1 inlet pressure (psia) - curve A } \\
& \text { PP11L = closed valve SRV inlet pressure (psia) - curve B } \\
& \text { YSRV = relief valve (SRV) position - curve C } \\
& \text { YSV1 = relief valve (SV1) position - curve D } \\
& \mathbf{T}=\text { time (s) }
\end{aligned}
$$




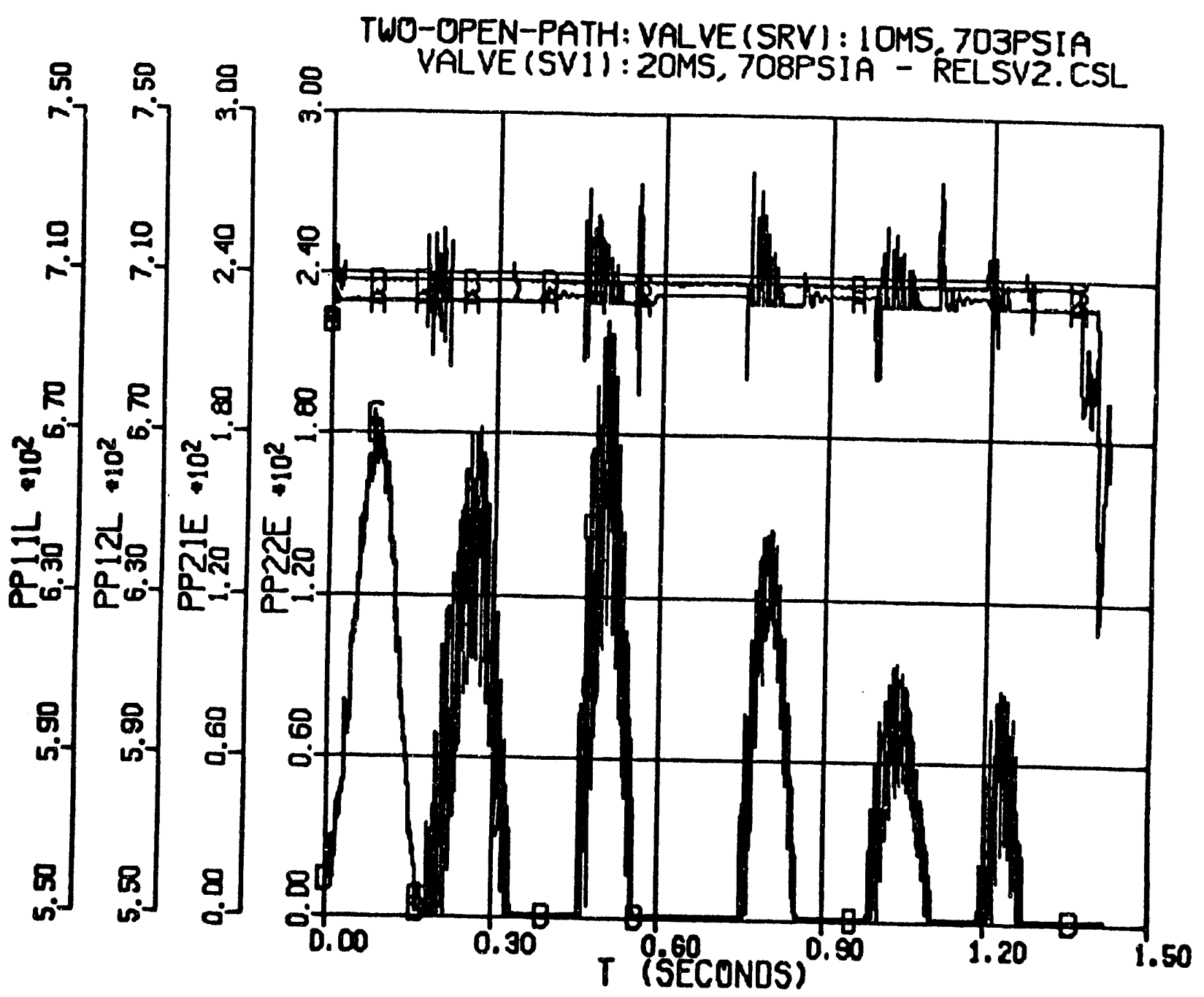

Fig. 4.4. The pressures at the inlet and exit of the valves and relief valve poxitions for position changing rates based on 10 and $20 \mathrm{~ms}$ opening and closing times and 703 and 708 psia pressure set points respectively during the first 0.1 seconds - two-open-path-model.

$$
\begin{array}{ll}
\text { PP11L = valve SRV inlet pressure (psia) } & \text { - curve A } \\
\text { PP12L = valve SV1 inlet pressure (psia) } & \text { - curve B } \\
\text { PP21E = valve SRV discharge pressure (psia) } & \text { - curve C } \\
\text { PP22E = valve SV1 discharge pressure (psia) } & \text { - curve D } \\
\text { T = time (s) } &
\end{array}
$$




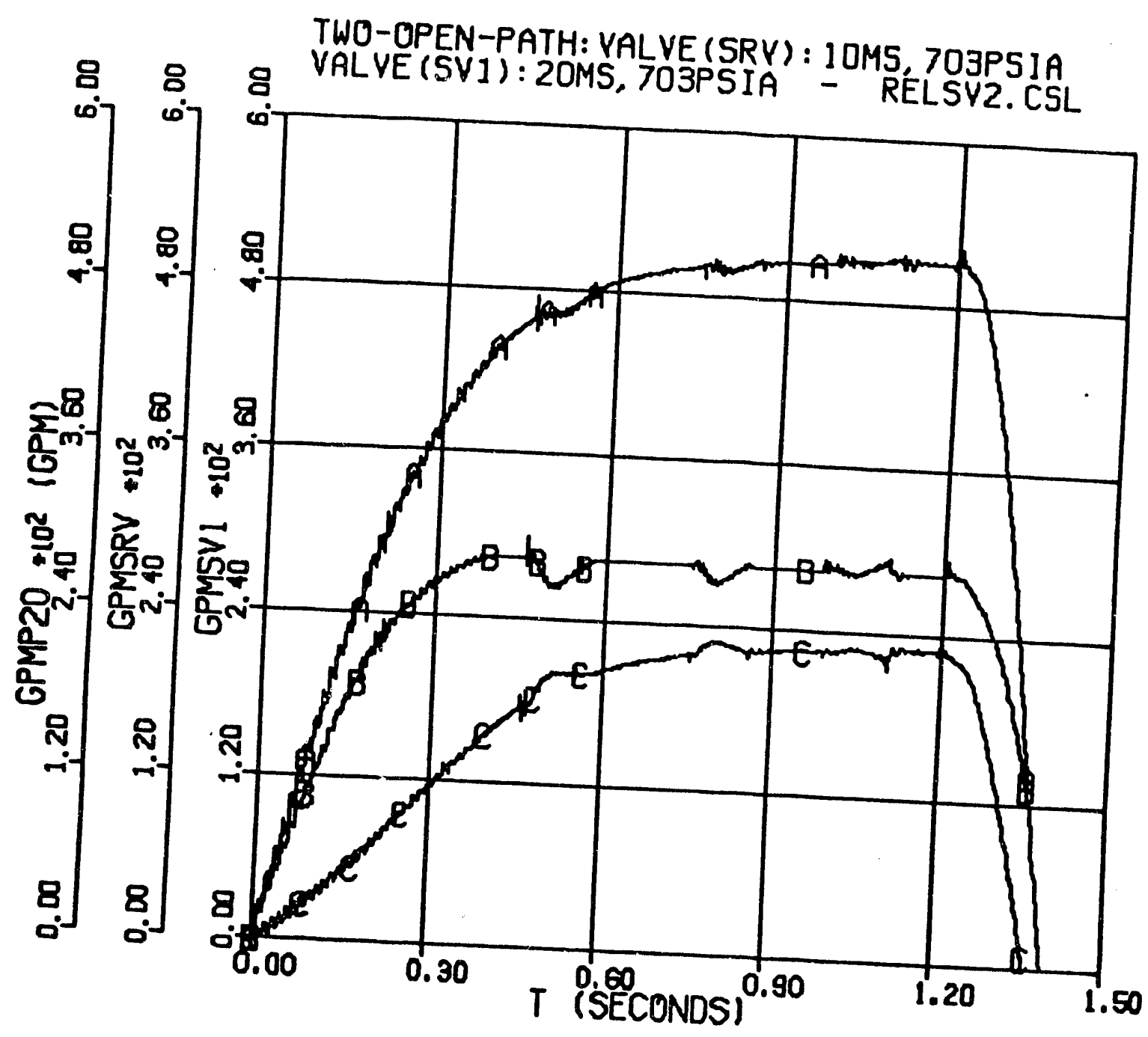

Fig. 4.5. The flow rates in gpm through the relief valves and main discharge piping for position changing rates based on 10 and $20 \mathrm{~ms}$ opening and closing times and 703 and 708 psia pressure set points respectively during the first 0.1 - two-open-path-model.

$$
\begin{aligned}
& \text { GPMP20 = main discharge piping flow (gpm) - curve A } \\
& \text { GPMSRV = relief value SRV flow rate (gpm) - curve B } \\
& \text { GPMSV1 = relief valve SV1 flow rate (gpm) - curve C } \\
& T=\text { time (s) }
\end{aligned}
$$




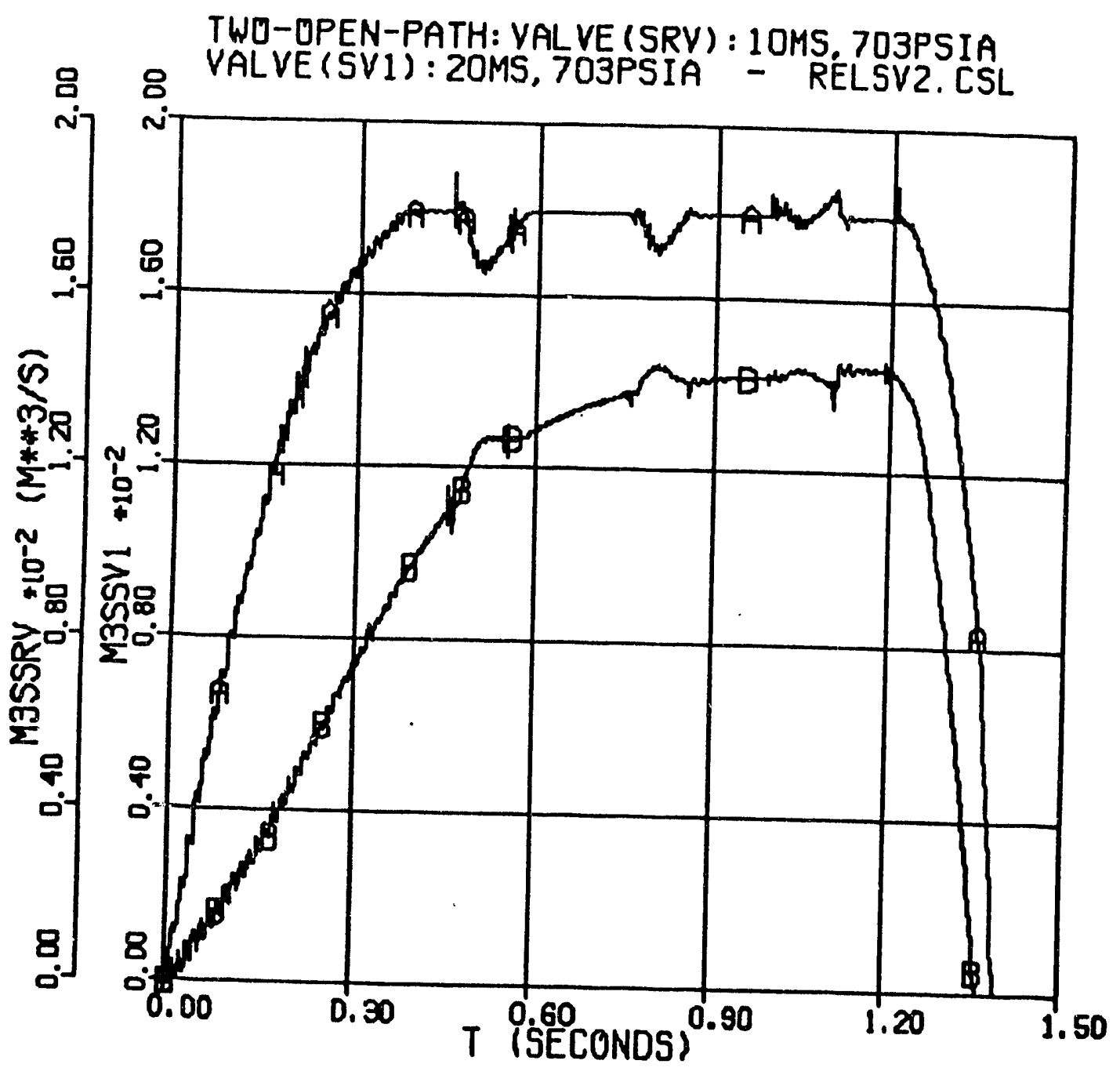

Fig. 4.6. The flow rates in $\mathrm{m}^{3} / \mathrm{s}$ through the relief valves and main discharge piping for position changing rates based on 10 and 20 ms opening and closing times and 703 and 708 psia pressure set points respectively during the first 0.1 s - two-open-path-model

$$
\begin{aligned}
& \text { M3SSRV = relief value SRV flow rate }\left(\mathrm{m}^{3} / \mathrm{s}\right) \text { - curve A } \\
& \text { M3SSV1 = relief vavle SV1 flow rate }\left(\mathrm{m}^{3} / \mathrm{s}\right) \text { - curve B } \\
& \mathbf{T}=\text { time (s) }
\end{aligned}
$$


of the pressure patterns around the relief valves. The back pressure oscillations occurred because of the difference between the flow rate into and out of the downstream pipe. The minimum calculated back pressure was equal to the vapor pressure of the liquid water (1.8 psia) indicating formation of steam and water mixture in the downstream of the valves. The pressure at the end of the downstream pipe was determined by the amount of water in the primary coolant storage tank and the atmospheric pressure. The tank pressure stayed constant (17.2 psia) during this transient. The flow rates through each valve and through the relief valve subsystem in gpm are shown in Fig. 4.5 and in $\mathrm{m}^{3} / \mathrm{s}$ in Fig. 4.6. The maximum flow rate through the valves were $298 \mathrm{gpm}$ at $100 \%$ opening and $231 \mathrm{gpm}$ at $94.7 \%$ opening. The combined maximum flow was about $533 \mathrm{gpm}$. This flow rate is much higher than what can be achieved if only one of the valves were open at the same pressure drop through the relief valve.

To provide a comparison, the same calculation was repeated utilizing two identical valves whose valve position changing rates based on $10 \mathrm{~ms}$ opening or closing time and whose set point pressures equal to 703 psia. The RELSV2.CSL program was used in this calculation as before. The equal percentage characteristics were conservatively assumed for the relief valves. The calculated relief valve positions (YSRV, YSV1) are shown in Fig. 4.7. Because the valves are identical, the curves overlap. This figure can be compared to Fig. 4.1. The pressures in psia at the cold leg (PP10E), at the inlet of $11 / 2$-in. pipe (PP10L), and at the inlet of the relief valves (PP11L), are shown in Fig. 4.8. The relief valve position is also presented in the figure so that the changes in the pressures can be associated with the changes in valve position. The flow rates through each valve and through the relief valve subsystem in gpm are shown in Fig. 4.9. The flow through the valves overlap because they are identical. The maximum flow through each valve was about $280 \mathrm{gpm}$ and through the relief valve subsystem about $560 \mathrm{gpm}$. The flow rates through the valves and main discharge piping in $\mathrm{m}^{3} / \mathrm{s}$ are presented in Fig. 4.10. The maximum flow through a single relief valve was about $0.0176 \mathrm{~m}^{3} / \mathrm{s}$. As in the previous test, the total flow rate is higher than what can be obtained through one open relief valve at a similar pressure drop. If the flow rate through two relief valves were lower than what can be obtained when only one valve is open or if the valves were chattering or fluttering, then degradation of the relief valve performance because of effects of each valve on the other would have become a significant concern.

Two similar calculations were performed using RELSVL.CSL which includes a model connecting the relief valves to the main downstream piping with a large volume. The results of these calculations support the conclusion reached in the previous paragraph.

A third test was performed to evaluate effects of a fast opening relief valve on the stability of the slow one, and vice versa when both of these relief valves have the same pressure set point. The valve position changing rates were based on $1 \mathrm{~ms}$ and $10 \mathrm{~ms}$ total opening or closing times. The relief valves started opening simultaneously and their position remained the same throughout the transient despite the difference in their constant position changing rates by a magnitude. Both of the valves were almost completely open in about $482 \mathrm{~ms}$. Their inlet pressures were identical. The maximum flow rates through individual valves were as high as $268 \mathrm{gpm}$. The maximum combined flow rate through the relief system was about $535 \mathrm{gpm}$. The outlet pressure of the relief valves decreased as low as the vapor pressure of the liquid water indicating presence of two-phase mixture. The MMS pipe 


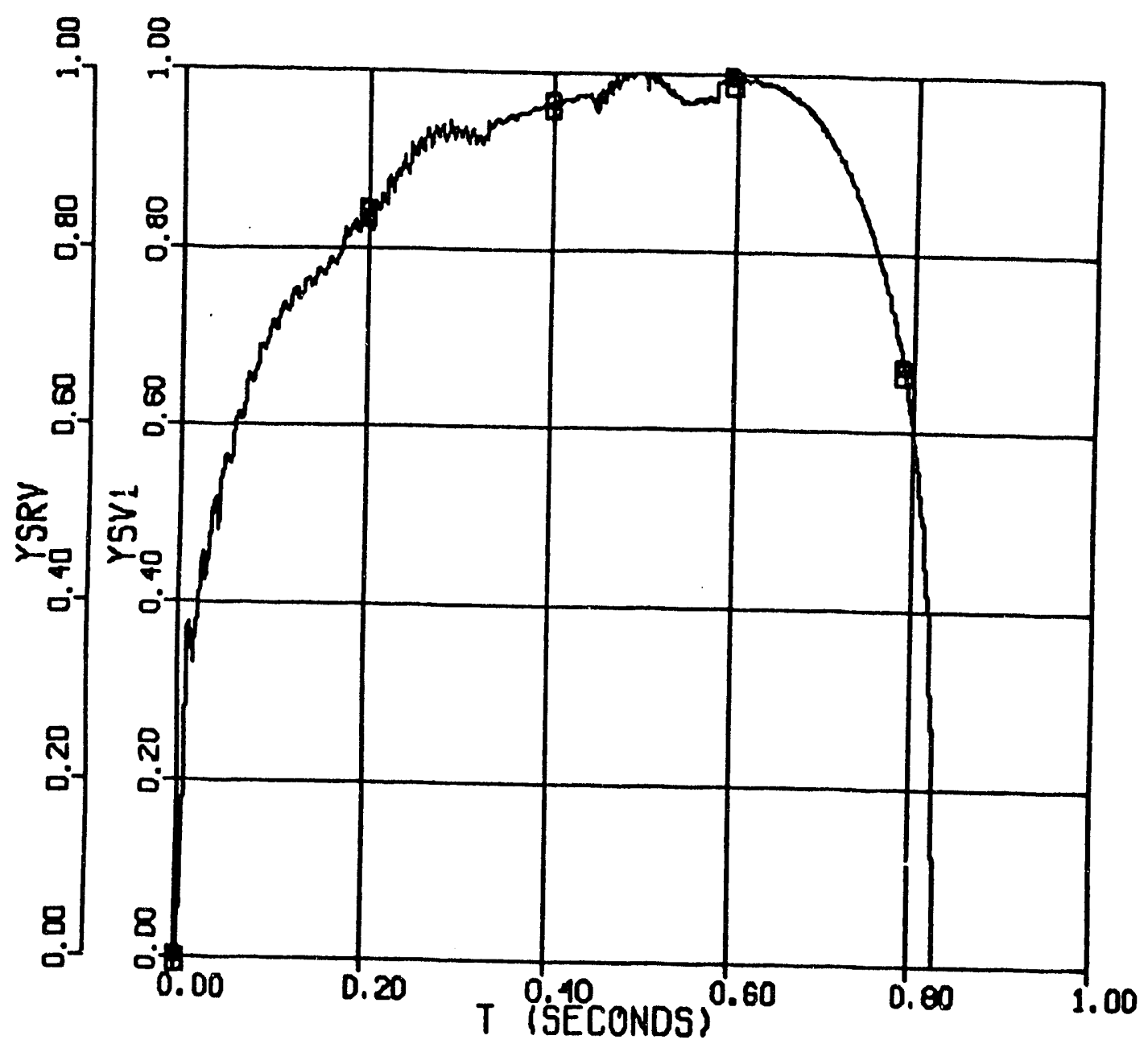

Fig. 4.7. The relief valve positions for position changing rates based on 10 and 10 ms opening and closing times and 703 and 703 psia pressure set points respectively two-open-
path-model.

$$
\begin{array}{rlr}
\text { YSRV } & =\text { relief valve (SRV) position } & \text { - curve A } \\
\text { YSV1 } & =\text { relief valve (SV1) position } & \text { - curve B } \\
T & =s &
\end{array}
$$




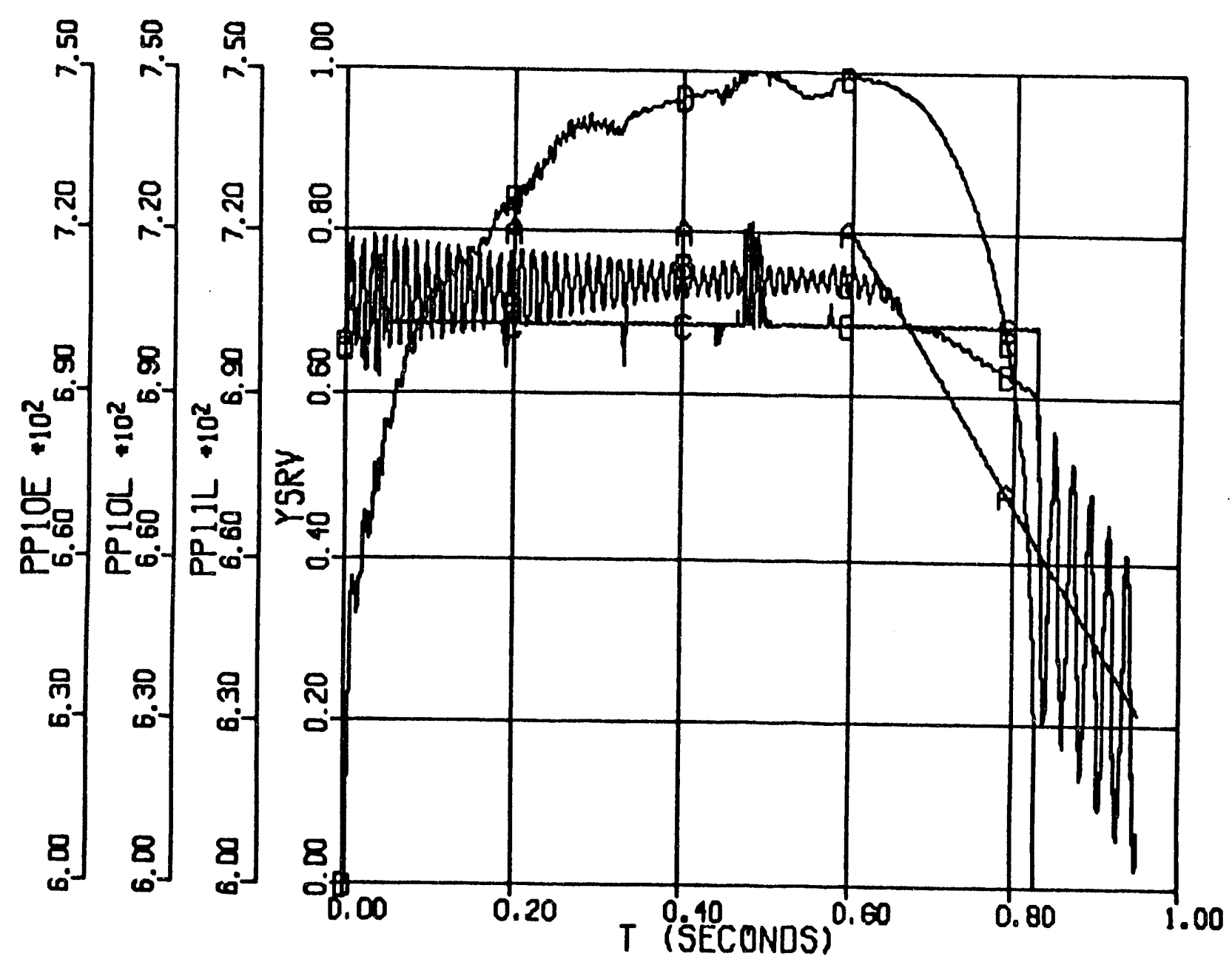

Fig. 4.8. The pressures at the cold leg, at the inlet of $11 / 2$ in. pipe and the relief valve, and relief valve position for position changing rate based on $10 \mathrm{~ms}$ opening and closing times and 703 psia pressure set point - two-open-path-model.

$$
\begin{aligned}
& \text { PP10E = cold leg pressure (psia) - curve A } \\
& \text { PP10L }=11 / 2 \text { in. pipe inlet pressure (psia) - curve B } \\
& \text { PP11L = relief valve (SRV) inlet pressure (psia) - curve C } \\
& \text { YSRV = relief valve (SRV) position - curve D } \\
& T=\text { time (s) }
\end{aligned}
$$




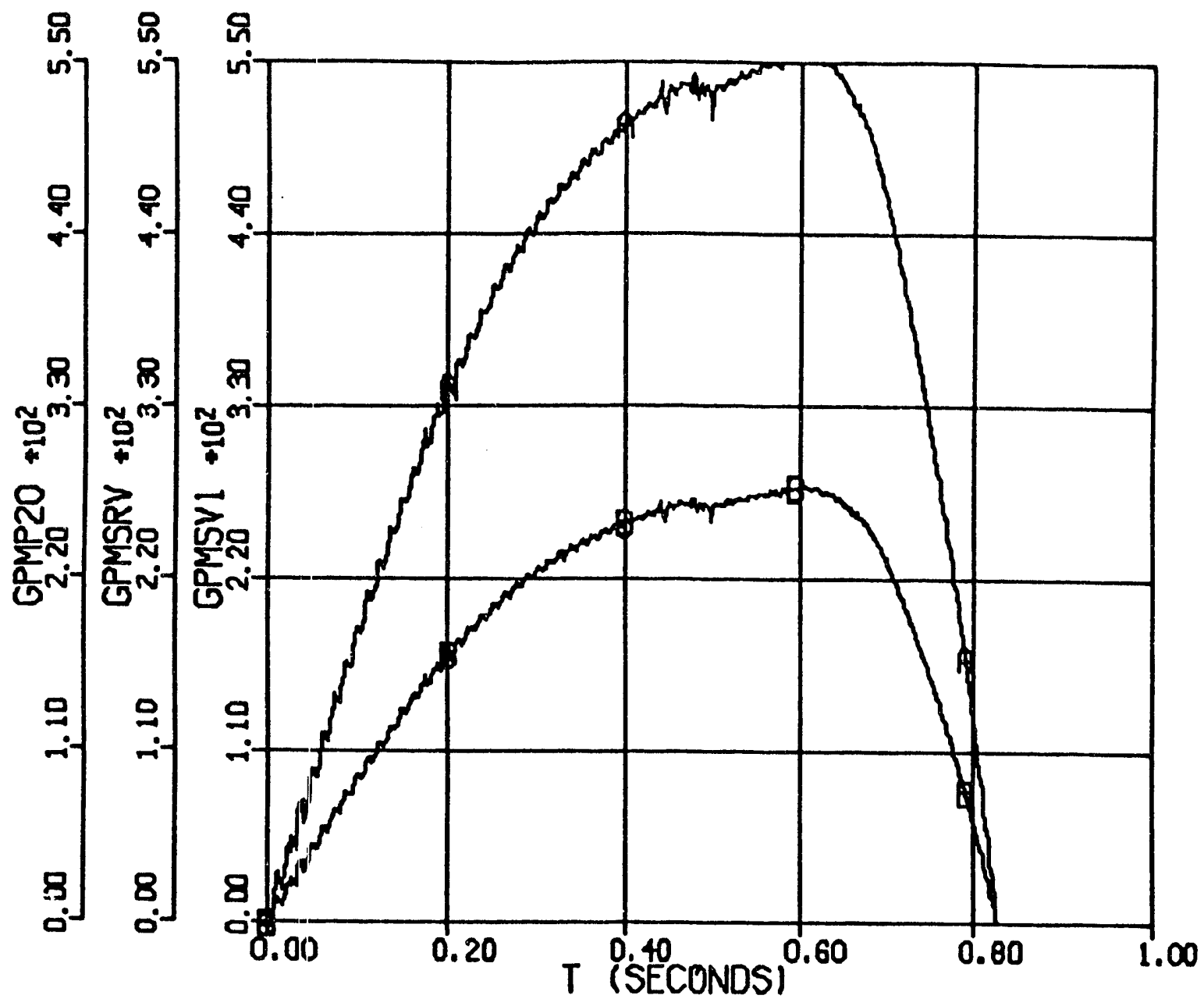

Fig. 4.9. The flow rates in gpm through the relief valves and main discharge piping for position changing rates based on 10 and $10 \mathrm{~ms}$ opening and closing times and 703 and 703 psia pressure set points respectively - two-open-path-model.

$$
\begin{array}{lll}
\text { GPMP20 } & =\text { main discharge piping flow (gpm) } & \text { - curve A } \\
\text { GPMSRV } & =\text { relief valve SRV flow rate (gpm) } & \text { - curve B } \\
\text { GPMSV1 } & =\text { relief valve SV1 flow rate (gpm) } & \text { - curve C } \\
\text { T } & =\text { time (s) }
\end{array}
$$




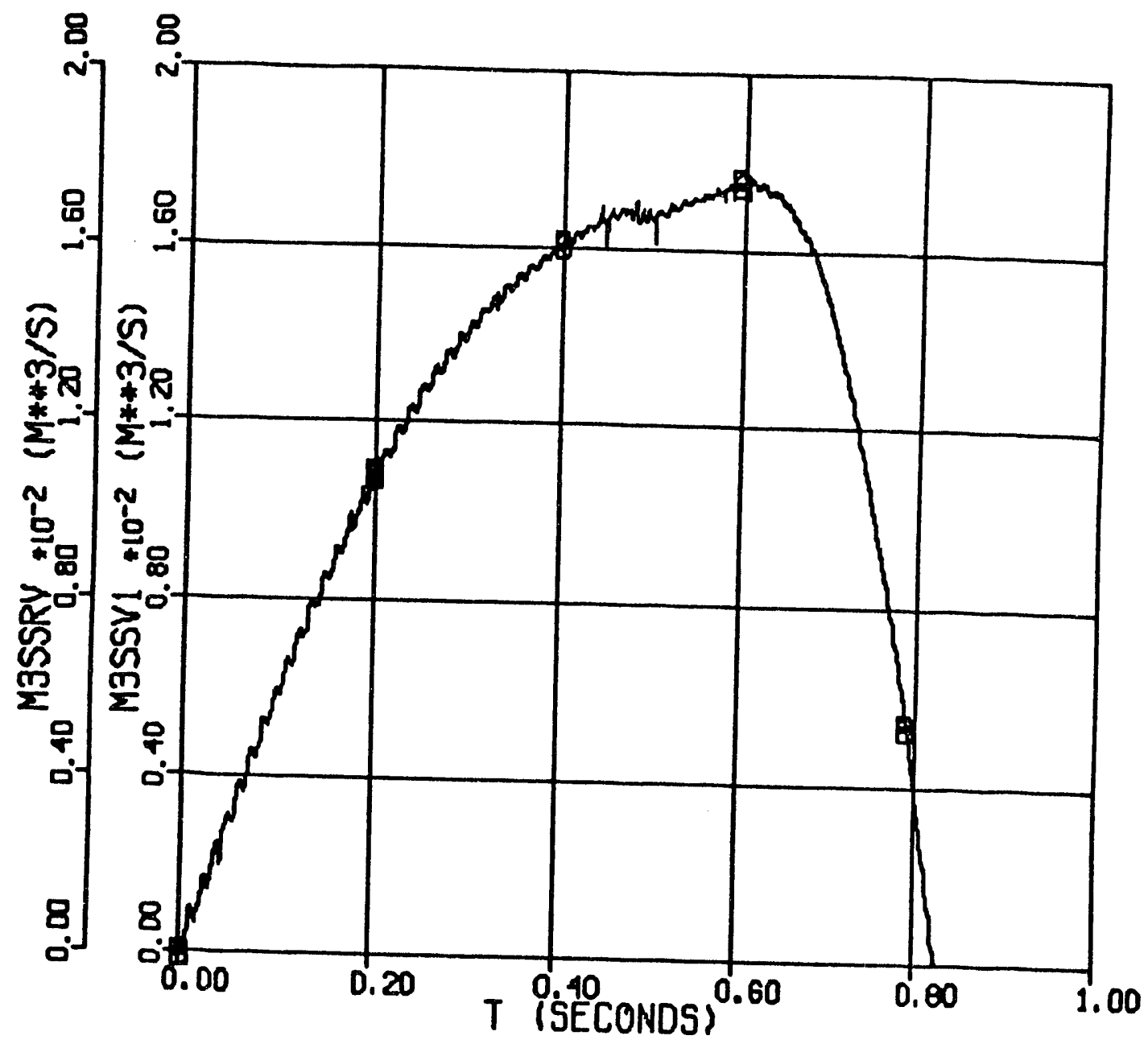

Fig. 4.10. The flow rates in $\mathrm{m}^{3} / \mathrm{s}$ through the relief valves and main discharge piping for position changing rates based on 10 and $10 \mathrm{~ms}$ opening and closing times and 703 and 703 psia pressure set points respectively - two-open-path-model.

$$
\begin{aligned}
& \text { M3SSRV = relief valve SRV flow rate }\left(\mathrm{m}^{3} / \mathrm{s}\right) \text { - curve A } \\
& \text { M3SSV1 = relief valve SV1 flow rate }\left(\mathrm{m}^{3} / \mathrm{s}\right) \text { - curve B } \\
& \mathrm{T} \quad=\text { time (s) }
\end{aligned}
$$


modules used in these calculations do not mechanistically model two-phase flow conditions; therefore, evaluation of the results requires acknowledgment of this deficiency in the model.

The conclusion in this category, only based on the tests performed, is that using oneopen-path approach (only one open relief valve) is conservative compared to two paths with both of the relief valves operating. The common sense will normally support this conclusion; however, it was not possible to decide without performing the calculations what level of chatter or flutter to expect when the relief valves operate at different position changing rates and set point pressures.

\section{Effects of Outlet Pressure on Relief Valve Performance}

\subsubsection{An assumed model of outlet pressure effect on relief valve opening pressure}

A final test was performed to analyze effects of the relief valve outlet or discharge pressure on the valve opening pressure based on several assumptions. In this study the body bowl pressure and the discharge pressure are assumed to be the same. The net effect of valve body bowl (chamber) pressure on the upper surface of the disk is assumed to be negligible compared to that of the outlet pressure on the lower surface of the disk. The surface area to which the outlet pressure is applied is assumed to be $80 \%$ of the surface area to which the valve inlet pressure is applied. Since the pop open pressure is set at 703 psia, an approximate value for the spring force applied downward on the valve stem may be obtained. The moment the valve pops open, the following simple equation may be written as an approximation:

$$
P_{p} A_{p}=F_{T}
$$

where

$P_{p}=$ valve inlet pressure (psia) keeping the valve stem in open position,

$A_{p}=$ area to which the valve inlet pressure is applied $\left(i^{2}\right)$, and

$\mathrm{F}_{\mathrm{T}}=$ spring force $\left(\mathrm{lb}_{\mathrm{f}}\right)$ acting in the opposite direction of the force due to valve inlet pressure.

Once the valve is open, the equation in its approximate form would be:

$$
P_{p} A_{p}+P_{b} A_{b}=F_{T}
$$

where

$P_{b}=$ discharge or outlet pressure (psia) and

$A_{b}=$ area to which outlet pressure is applied (in. ${ }^{2}$ ) 
Setting pop open pressure equal to pressure set point, a value for $F_{T} / A_{p}$ is obtained:

$$
P_{p}=\frac{F_{T}}{A_{p}}=703 \text { psia }
$$

The equation for open valve position is reorganized to calculate $P_{p}$ as a function of the area ratio $\left(A_{b} / A_{p}\right)$ and outlet pressure $P_{b}$ :

$$
P_{p}=703.0-P_{b} \frac{A_{b}}{A_{p}}
$$

Then for a given area ratio, the valve opening pressure may be calculated based on the outlet pressure. Note that this approximation neglects the pressure applied to the upper surface of the disk and emphasizes the outlet pressure effect for a given area ratio $\left(A_{b} / A_{p}\right)$. If the magnitude of the pressure acting on the upper surface of the disk is close to that of the outlet pressure, the discharge or outlet pressure effect tends to be neutralized (assuming that the application areas are the same) and valve opening pressure would not be affected by the outlet pressure. A correlation for calculating the valve bowl pressure or the pressure on the portion of the upper surface of the disk in contact with the fluid is not available for the HFIR relief valves. The relief valve model used in the independent relief valve subsystem models does not distinguish the difference between the pressures of the body bowl region, the region above the disk filled with the fluid and discharge region. In other words, the pressure is the same throughout these regions in the independent models. The pressure of this region above the disk filled with the fluid will change as the valve stem rapidly moves up and diwn during opening and closing of the valve. This region is referred to as the disk seat cavity and connected to the body bowl region through a what appears to be an orifice, which is referred to as the seat cavity vent, in Langerman's study. ${ }^{9}$ Since the seat cavity vent is a limited opening, the pressure in the disk seat cavity region, the region above the disk filled with the fluid, will not be the same as the pressure in the body bowl region (or the pressure in the discharge of the valve) during rapid stem movements. There will be flow back and forth between the disk cavity and body bowl regions until the pressures in these two regions reach an equilibrium. The equation for calculation of $P_{p}$ is included in RELMAL.CSL, and RELMA2.CSL and RELMA3.CSL so that the valve opening pressure is continually calculated based on the discharge or outlet pressure.

\subsubsection{Analysis of outlet pressure effect on relief valve performance}

To investigate effects of the back pressure in simulation of valve performance during opening and closing, three calculations were performed. The cold leg pressure was increased from an initial value of 700 to 720 psia and retained at that value. The relief valve position changing rate was based on $10 \mathrm{~ms}$ opening or closing time. The original set point pressure (assumed to be the same as pop open pressure) was set at 703.7 psia.

The first calculation was performed utilizing RELMAL.CSL. The relief valve opened when the inlet pressure reached the set point pressure. After completely opening, the relief valve gradually closed down to about $70 \%$ although the cold leg pressure was kept above the original set point pressure. The relief valve reopened $100 \%$ after going through a minimum 
of about $70 \%$. The valve position displayed a periodic cycling through the duration of the transient (Fig. 5.1). The cycling behavior of the valve did not show weakening within the first five minutes after it opened fully for the first time. During the test the cold leg pressure was kept above the original pop open pressure of the relief valves until it was deliberately lowered to close them.

Rapid pressure oscillations larger than 60 psi occurred at the relief valve inlet (Fig. 5.2). The pressure needed to keep the relief valve in the open position, $P_{p}$, showed similar periodic changes (Fig. 5.3). The flows into and out of the main large volume downstream pipe are shown in Fig. 5.4. The difference between these flow rates causes significant changes in the outlet pressure (Fig. 5.5). In the figure, the relief valve inlet pressure and position are also presented. Since the periodic movement did not indicate dampening within the first $5 \mathrm{~s}$, the calculation was terminated by lowering the cold leg pressure to cause the valve completely close.

The calculation was repeated using RELMA2.CSL. The RELMA2.CSL program includes the short pipe section at the discharge of the relief valve connected to the main downstream piping. The relief valve position indicated similar periodic cycling changes; however, the period was roughly $17 \%$ shorter than the previous value. The significance of this calculation is to estimate whether or not the valve stays near open position but not to calculate a good estimate for the period. The minimum valve position calculated during periodic cycling remained above $70 \%$ during the transient. The periodic changes in the valve position, pressures and flow rates were very similar to those of the first calculation.

The calculation was repeated one more time after the short pipe at the exit of the relief valve was divided into two shorter pipes (RELMA3.CSL). This was done in order to find out whether or not the results were very sensitive to downstream node sizes and number of downstream piping nodes. Apart from a period that was shorter than two previous cases, the minimum valve position remained about $70 \%$ during the periodic oscillations. Clearly the cycling period depended on the choices made for the number of nodes in downstream piping. The minimum valve position during periodic changes did not appear to have dependency on the number of nodes. Note that the pressure acting on the portion of the upper surface of the disk in contact with the fluid was assumed to be negligible in all of these computations. The said pressure applied to a portion of the upper surface of the disk tends to counter balance the outlet pressure applied to a portion of the lower surface of the disk.

Conclusion in this category is that since the valve did not drastically close to prevent flow through it during its periodic cycling under the assumptions exaggerating the outlet pressure effect, neglecting the outlet pressure effect on valve opening pressure is acceptable if the relief valve has quick opening characteristics. The quick opening characteristic indicate near full flow capacity at about $40-50 \%$ opening. Because data about internal dimensions, weight of the valve stem, spring constant, form loss factors from the inlet of the valve to the body bowl or a correlation for calculating body bowl pressure, the pressure on a portion of the upper surface of the disk in contact with the fluid and the loss factor from the body bowl to the outlet of the valve where it is connected to the downstream pipe are not available, a detailed and a more realistic analysis than what was performed in this category could not be performed. 


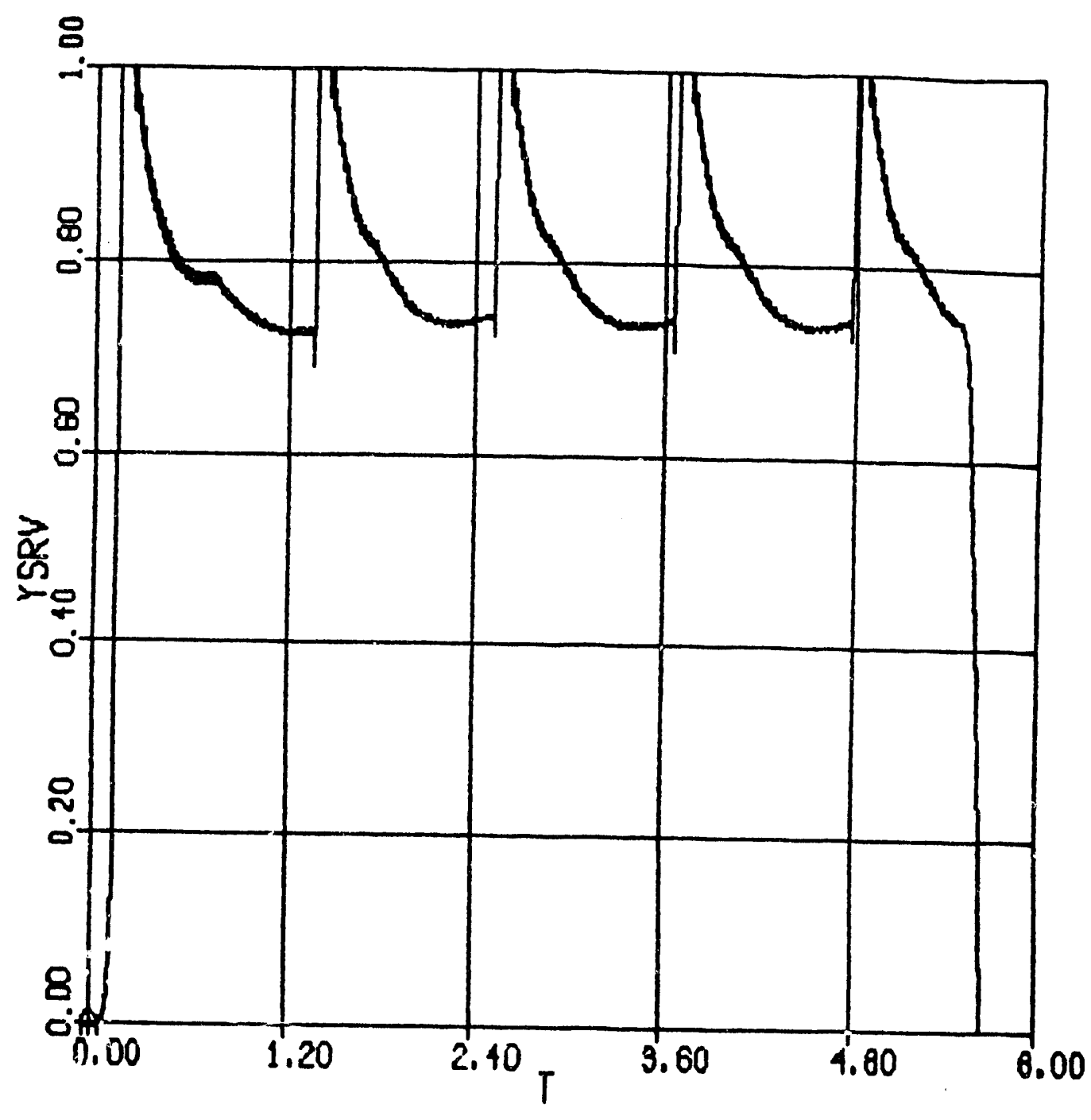

Fig. 5.1. The relief valve position for a position changing rate based on $10 \mathrm{~ms}$ opening or closing time and 703 psia pressure set point - one-open-path with back pressure
model.

$$
\begin{aligned}
\text { YSRV } & =\text { relief valve position } \\
\mathbf{T} & =\text { time }(\mathbf{s})
\end{aligned}
$$




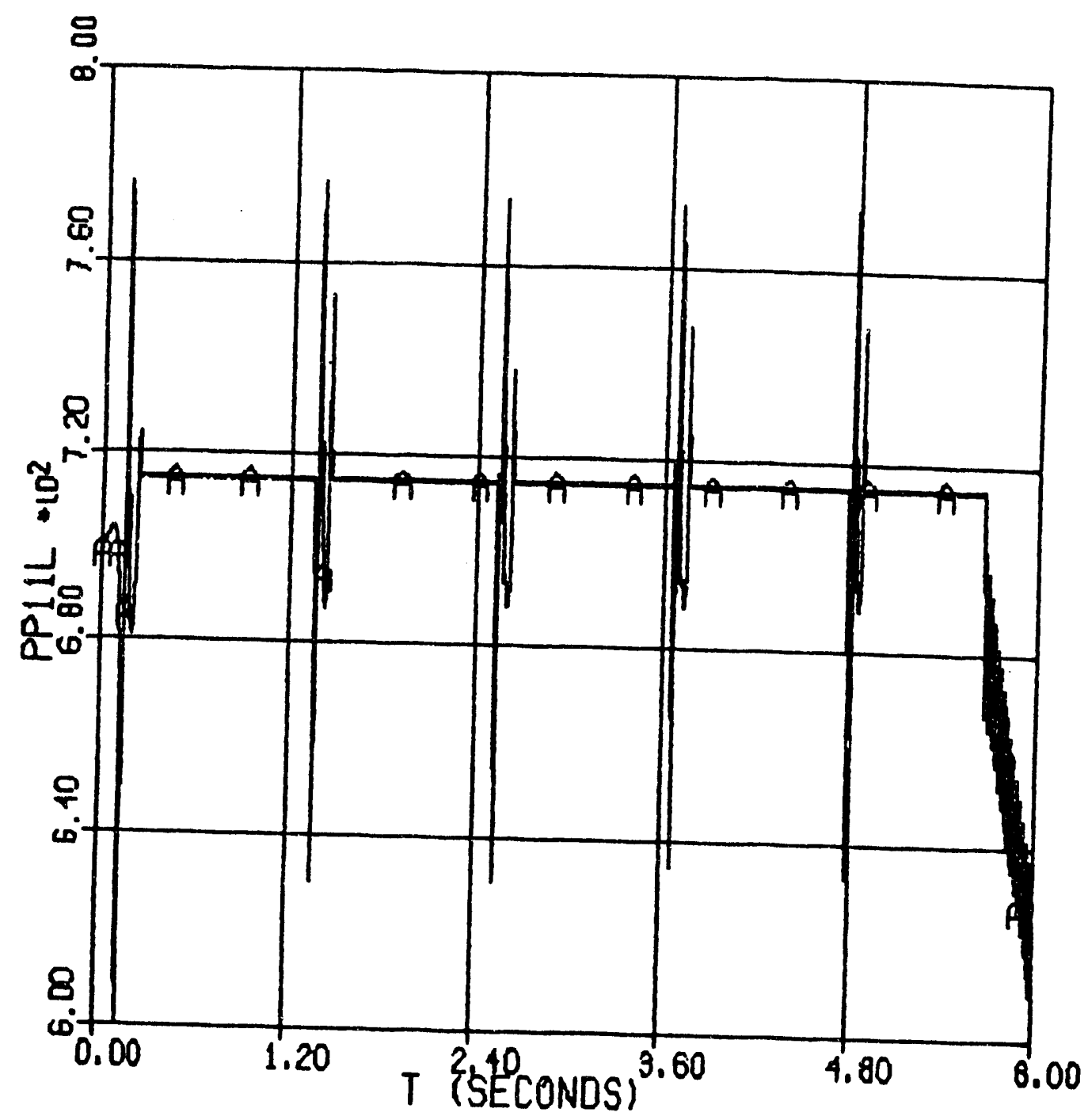

Fig. 5.2. The relief valve inlet pressure for a position changing rate based on $10 \mathrm{~ms}$ opening or closing time and 703 psia pressure set point - one-open-path with back pressure model.

$$
\begin{aligned}
\text { PP11L } & =\text { valve SRV inlet pressure (psia) - curve A } \\
T & =\text { time (s) }
\end{aligned}
$$




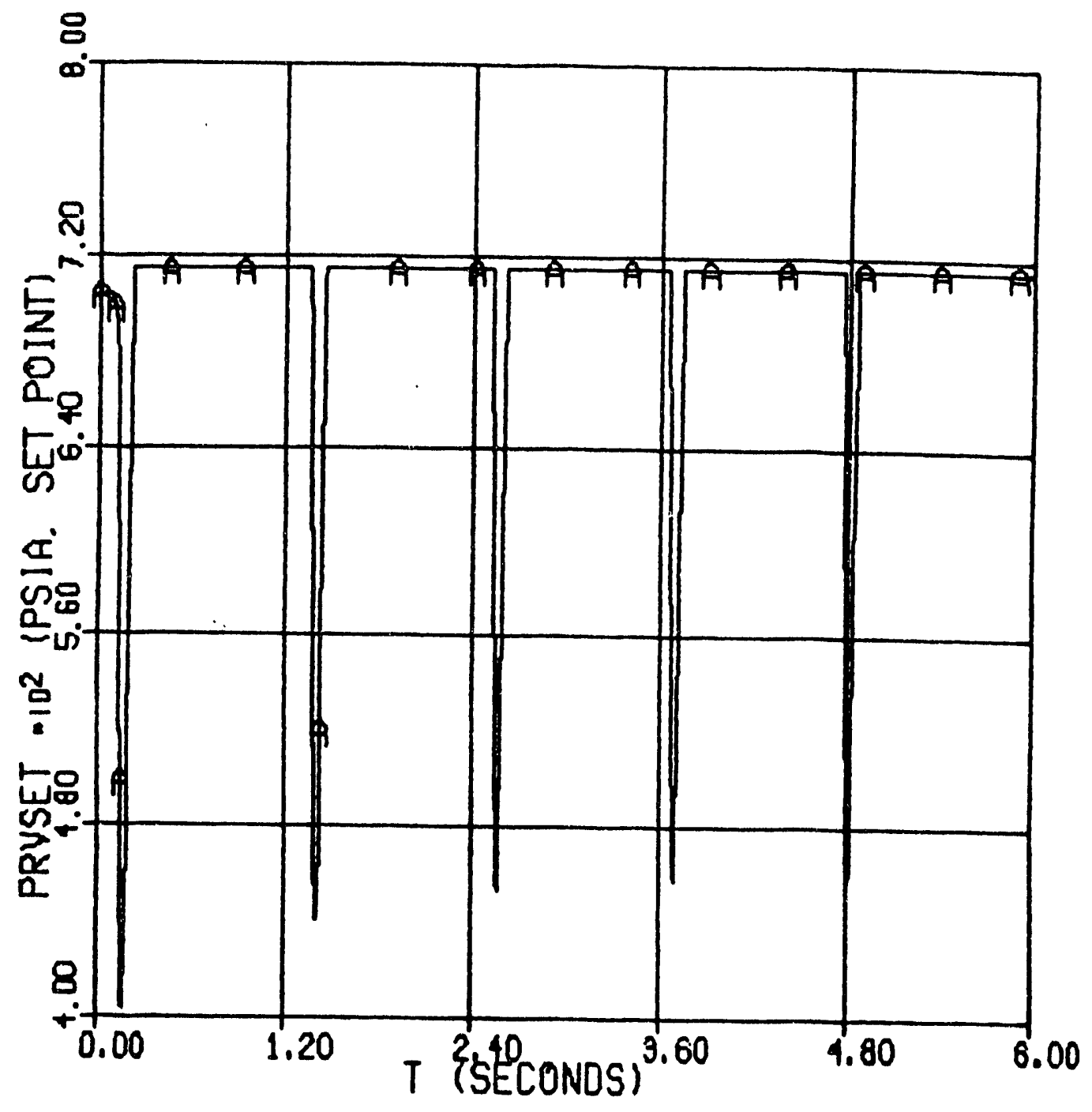

Fig. 5.3. The relief valve opening pressure as a function of back presure for a position changing rate based on $10 \mathrm{~ms}$ opening or closing time and 703 paia set point
pressure.

$$
\begin{aligned}
& \text { PRVSE } \\
& \mathbf{T}=\text { valve opening pressure (psia) - curve A } \\
& =\text { time (s) }
\end{aligned}
$$




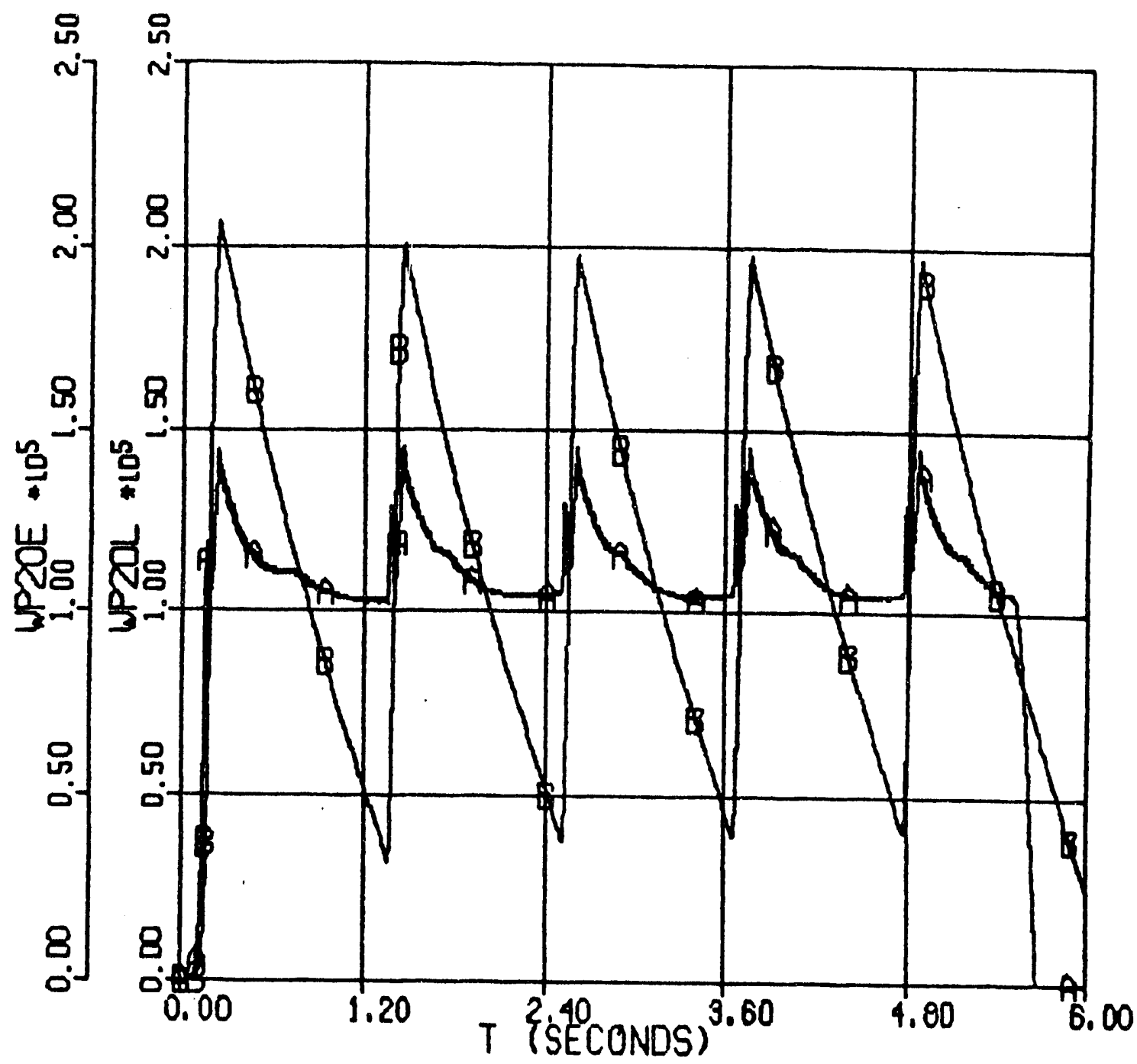

Fig. 5.5. The inlet and discharge pressures of the relief value and valve position for a position changing rate based on 10 ms opening or closing time and 703 psia pressure set point one-open-path with back pressure model.

$$
\begin{aligned}
& \text { PP11L = relief valve inlet pressure (psia) - curve A } \\
& \text { PP20E = relief valve discharge press (psia) - curve B } \\
& \text { YSRV = relief valve position - curve } C \\
& \text { T }=\text { time (s) }
\end{aligned}
$$




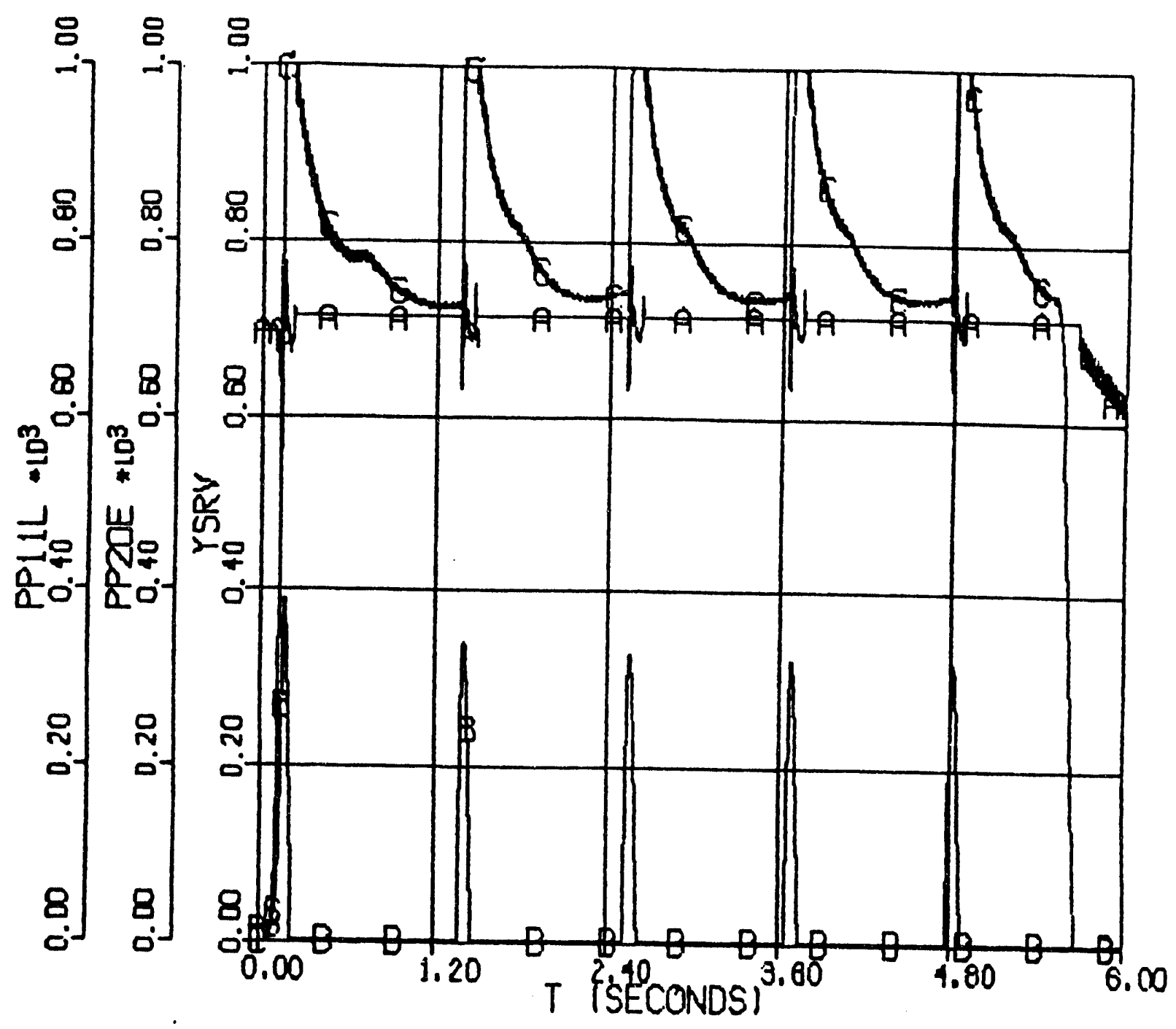

Fig. 5.4. The main downstream piping inlet and outlet flow rates for a position changing rate based on $10 \mathrm{~ms}$ opening or closing time and 703 psia pressure set point - oneopen-path with back pressure model.

$$
\begin{aligned}
& \text { WP20E }=\text { main discharge piping inlet flow }\left(1 b_{d} / h\right) \text { - curve A } \\
& \begin{aligned}
\text { WP20L } & =\text { main discharge piping outlet flow }(\mathbf{l b} / \mathbf{h}) \text { - curve B } \\
T & =\text { time }(\mathbf{s})
\end{aligned}
\end{aligned}
$$




\section{SUMMMARY}

The pressurizer pump overspeed transients will include challenging the relief valves to open as the primary coolant system pressure rises to the set point pressure of the relief valves. The performance of the HFIR relief valves is crucial in handling the high pressure event. If the relief valves do not open, the primary coolant system's high pressure boundary is challenged. The analyses in this report included two main portions:

1. Analysis of relief valve stability and performance during high pressure subcooled liquid water flows. This portion uses the independent relief valve subsystem models and does not include the primary system model.

2. Simulation of the pressurizer pump overspeed transients. The HFIRSYS model does not include the upstream and downstream piping of the relief valves. The relief valves, the primary coolant storage tank, and the primary coolant system are included in the model.

The purpose of the first analysis is to estimate how long it will take for the relief valves to open under different conditions and whether or not they will chatter or flutter for a considerable amount of time. The significance of chatter or flutter has to do with the potential of the relief valves not being able to release coolant at a fast enough rate to prevent the primary system pressure from rising. If the relief valve is considered to be, for example, half open throughout a transient or during the first 3 to $10 \mathrm{~s}$ of the pressurizer pump overspeed transient, the valve characteristics become important. If all of the relief valves have been designed as quick opening valves, the valve full capacity is almost achieved at half open position. However, the linear and especially the equal percentage characteristics can result in small flow and high system pressures.

The first analysis estimates relief valve performance and stability under different conditions using four different relief valve subsystem models. The models included the upstream and downstream piping so that effects of the piping on valve performance and stability is predicted under different conditions such as varying opening and closing times (valve position changing rates), set points, one or two paths being available, and different cold leg pressurization rates. The primary coolant system pressure was represented as a boundary condition and input to the program.

In all of the cases analyzed using the relief valve subsystem models, the pressure oscillations were produced. These waves cause the relief valve to open much later than the preassigned opening time as the valve responds to increasing and decreasing inlet pressure around the set point pressure. However, the relief valve was able to fully open in $<1 \mathrm{~s}$ in all of the cases analyzed in the report. Since it takes about $10 \mathrm{~s}$ for the pressurizer pump to achieve its maximum speed, $<1 \mathrm{~s}$ opening time may be tolerated without a significant level of concern.

In the second analysis, HFIRSYS (the HFIR system transient analysis computer model) was used to simulate the runaway pressurizer pump speed transients also referred as 
over-pressurization transients. These transients were previously simulated using the RELAP5/MOD2.5 computer code. The HFIRSYS results provide a check on accuracy and technical adequacy of the RELAP5/MOD2.5 results and further evidences our reliance on RELAP5/MOD2.5 as the primary safety analysis tool.

Although the RELAP5/MOD2.5 thermal-hydraulic computer code has been widely used in applications for light water reactors, LWRs, it had not been applied to the reactors with solid primary coolant systems (no gas or vapor space) like HFIR. HFIRSYS provides much needed backup. In the transient simulations performed using RELAP5/MOD2.5, a $0.1 \mathrm{~s}$ opening time was assigned to the relief valves. The relief valve inlet pressure was assumed to be equal to the cold leg pressure in order to prevent pressure oscillations and valve chatter and flutter from occurring. Prior to performing these transient simulations, relief valve performance and stability were not investigated in a separate analysis to support the assumptions. The first analysis performed using the relief valve subsystem models in this report is instrumental in checking validity of those assumptions. The results of the simulations of the runaway pressurizer pump speed transients performed using HFIRSYS indicate that at least one relief valve must be fully open to prevent the primary coolant system pressure from rising above the relief valve set point pressure.

Calculations, in addition to the pressurizer pump overspeed transient simulations performed using HFIRSYS and RELAP5/MOD2.5, were carried out to further investigate effects of the valve characteristics and the relief valve back pressure ratio on the primary coolant system pressure for the transient case which does not allow the pressurizer pump to trip either on low suction pressure or high discharge pressure. Since the relief valves are challenged to open, the behavior of the relief valve and its characteristics play a significant role. The equal percentage characteristics resulted in the highest rise in the primary coolant system pressure while the quick opening characteristics kept the system pressure near the relief valve set point pressure when the relief valve remained in half open position throughout the transient. These computations were carried out using HFIRSYS. In order to estimate a high limit for the primary coolant system pressure due to a high back pressure ratio, the back pressure percent was assumed to be equal to $50 \%$ corresponding to a flow factor of 0.675 in a separate computation simulating the same transient performed using HFIRSYS. The calculated maximum system pressure rose about 140 psi above the set point pressure of the relief valves. The maximum system pressure with a low back pressure percent corresponding to a flow factor equal to 1, which was used in all of the RELAP5/MOD2.5 and HFIRSYS transient simulations, was near the opening set point pressure of the relief valves for the same transient.

In summary, two sets of analyses were performed in support of the pressurizer pump overspeed transients. One including a detailed analysis of the relief valve performance and stability using the relief valve subsystem models. (The extent of this analysis was limited to the available data.) The other includes simulation of all the transients using the HFIRSYS system transient analysis code to provide a referable comparison base to the results of the RELAP5/MOD2.5 simulations. Additional separate computations were performed to specifically examine effects of valve characteristics and relief valve back pressure ratio on maximum primary coolant system pressure. 


\section{REFERENCES}

1. HFIR FSAR CHAPTER 6 - INTERFACES WITH OTHER FSAR CHAPTERS HFG-INT.11, H. G. O'Brien, April 8, 1991. (Section 6.11 - Pressure Relief System, HFIR FSAR CHAPTER 6 - Questions - Open Issues - Set 5, HF6-Q-5).

2. EPRI PWR Safety and Relief Valve Test Program Safety and Relief Valve Test Report, NP-2628-SR, Dec. 1982.

3. A. Singh, "On the Stability of a Coupled Safety Valve - Piping System," EPRI, Palo Alto, California in Testing and Analysis of Safety/Relief Valve Performance, The ASME Winter Annual Meeting, Phoenix, Arizona, November 15-19, 1982.

4. J. R. Zahorsky, "Degradation of Pressure Relief Valve Performance Caused by Inlet Piping Configuration," Crosby Valve Division, Geosource Inc., Wrentham, MA 02093 in Testing and Analysis of Safety/Relief Valve Performance, The ASME Winter Annual Meeting, Phoenix, Arizona, November 15-19, 1982.

5. A. J. Stepanoff, Centrifugal and Axial Flow Pumps Theory, Design, and Application, John Wiley \& Sons, Inc., 2nd Edition, pp. 425-428.

6. A. Singh, "A Correlation for Safety Valve Blowdown and Ring Settings," EPRI, Palo Alto, California 94303. Testing and Analysis of Safety/Relief Valve Performance, The American Society of Mechanical Engineers, United Engineering Center, 345 East 47th Street, New York, N.Y. 10017.

7. A. Singh, A. M. Hecht, M. E. Teske, "A Model For Predicting the Performance of Spring-Loaded Safety Valves," in Testing and Analysis of Safety/Relief Valve Performance, The American Society of Mechanical Engineers, United Engineering Center, 345 East 47th Street, New York, N.Y. 10017

8. A. Singh, D. Shak, "Modeling of a Spring-Loaded Safety Valve," in Testing and Analysis of Safety/Relief Valve Performance, The American Society of Mechanical Engineers, United Engineering Center, 345 East 47th Street, New York, N.Y. 10017.

9. M. A. Langerman, "An Analytical Model of a Spring-Loaded Safety Valve," in Testing and Analysis of Safety/Relief Valve Performance, The American Society of Mechanical Engineers, United Engineering Center, 345 East 47th Street, New York, N.Y. 10017.

10. Testing and Analysis of Safety/Relief Valve Performance, The American Society of Mechanical Engineers, United Engineering Center, 345 East 47th Street, New York, N.Y. 10017.

11. EPRI PWR Safety and Relief Valve Test Program Safety and Relief Valve Test Report, NP-2628-SR, Dec. 1982. 
12. R. K. House, M. A. Langerman, D. L. Caraher, and C. A. Cordes, "Calculation of Safety Valve Discharge Piping Hydrodynamic Loads Using RELAP5/MOD1," Intermountain Technologies, Inc., Idaho Falls, Idaho. Testing and Analysis of Safety/Relief Valve Performance, The American Society of Mechanical Engineers, United Engineering Center, 345 East 47th Street, New York, N.Y. 10017.

13. R. K. House, M. A. Langerman, D. L. Caraher, G. A. Cordes, and J. C. Wells, Application of RELAP5/MOD1 for Calculation of Safety and Relief Valve Discharge Piping Hydrodynamic Loads, NP-2479, December 1982.

14. T. D. Radcliff and B. L. Lepard, Jr. "Description of Reactor Transients to be Analyzed for the Completion of the Accident Analyses in Chapter 15 of the High Flux Isotope Reactor Safety Analysis Report (SAR)," ORNL, Research Reactors Division, January 1, 1991.

15. A. Sozer, A System Analysis Computer Model For The High Flux Isotope Reactor (HFIRSYS Version 1), (in publication) ORNL/TM-11611, April 1992.

16. Modular Modeling System (MMS): A Code for the Dynamic Simulation of Fossil and Nuclear Power Plants, Volume 1: Theory Manual, Babcock \& Wilcox, March 1985.

17. A. Sozer and M. W. Wendel, "Solid Primary Coolant System Response to A Small Break", ANS Transactions, Orlando Florida, June 2-6, 1991.

18. L. Lepard, "RELAP5/MOD2.5 Model of the HFIR Pressure Relief System," C-HFIR92-003, (RRD calculation) 5/12/92.

19. J. W. Hutchison, ISA Handbook of Control Valves, Instrument Society of America, Research Triangle Park, North Carolina, 1976.

20. Crosby Valve and Gage Company Catalog No. 322, "High Performance Pressure Relief Valves for Liquid Service, Crosby Styles JLT, JMBL, and JRL," May 1986. 
ORNL/TM-12215

\section{Internal Distribution}

1. J. C. Conklin

2. D. H. Cook

3. W. G. Craddick

4. G. F. Flanagan

5. J. D. Freels

6. R. E. Hale

7. R. M. Harrington

8. J. E. Jones Jr.

9. T. S. Kress

10. B. L. Lepard

11. D. G. Morris

12. L. D. Proctor
13. A. E. Ruggles

14. M. Siman-Tov

15-19. M. C. Sozer

20. M. W. Wendel

21. C. D. West

22. G. L. Yoder

23. ORNL Patent Section

24-25. Laboratory Records Department

26. Laboratory Records (RC)

27-28. Central Research Library

29. Document Reference Section

External Distribution

30. Office of Assistant Manager for Energy Research and Development, DOE-Oak Ridge Field Office, P.O. Box 2001, Department of Energy, Oak Ridge, TN 37831-8600

31-40. Office of Scientific and Technical Information, P.O. Box 62, Oak Ridge, TN 37831 

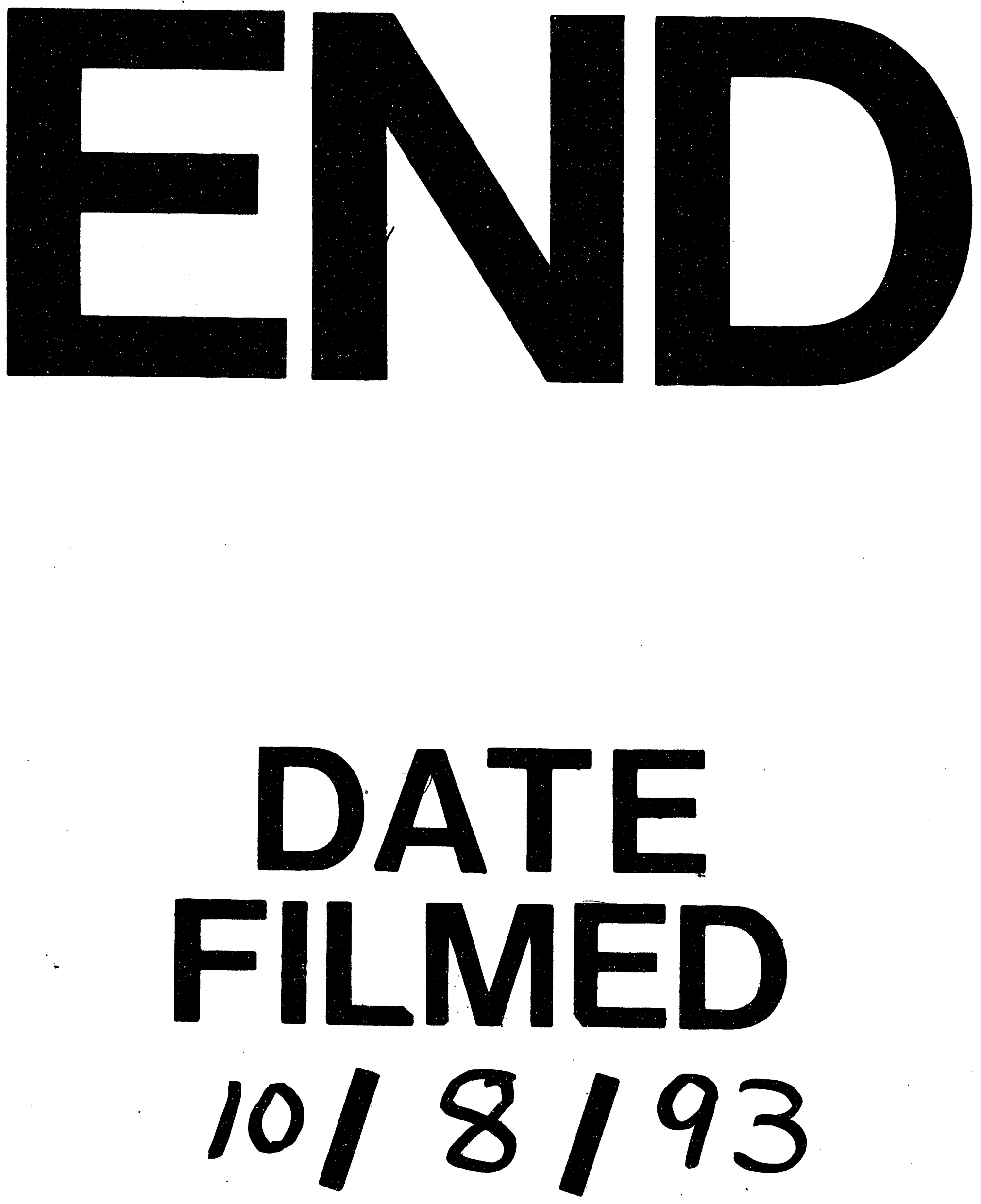

1 
